\title{
GLACIAL-METEOROLOGICAL OBSERVATIONS \\ ON ICECAPS IN BAFFIN ISLAND
}

\author{
A Thesis \\ Presented to \\ The Faculty of Graduate Studies and Research \\ VicGill University
}

In Partial Fulfillment

of the Requirements for the Degree

Doctor of Philosophy

by

Svenn Orvig, M.Sc.

Montreal, Que.

May 1954 


\section{PREFACE}

This work contains the results of meteorological observations carried out during the surnmer of 1953 on the Penny Icecap, and many references to similar investigations by me on the Barnes Icecap in 1950. These latter observations were used as the naterial for my thesis, "The climate of the Ablation Period on the Barnes Ice-cap in 1950," presented to the Faculty of Graduate Studies and Research, McGill University, in May 1951, for the Degree Master of Science.

In 1949 I was happy to follow Professor F. K. Hare's suggestion that I see Mr. P. D. Baird, Director of the Montreal Office of the Arctic Institute of North America, about participation in the Institute's 1950 Baffin Island Expedition. From my first meeting with. Mr. Baird there have followed five, for me, fruitful and interesting years of collaboration, and I wish to thank him for making me a member of the two Arctic Institute Baffin Island Expeditions. I must also express my gratitude to Dr. F. K. Hare, Chairman of the Department of Geography, McGill University, for help and personal interest in my work on the glacial-meteorological problems of Baffin Island icecaps.

I owe much to Mr. W. H. Ward of the United Kingdom Department of Scientific and Industrial Research, my colleague on the two icecaps, and an extremely able, energetic and resourceful companion. It is mainly due to his skill that we 
succeeded in carrying out our program.

I wish to thank Mir. A. Thomson, Controller, Meteorological Livision, Department of Transport, Toronto, for the loan of valuable instruments, especially the Actinograph.

Finally, I owe thanks to my wife for able help in checking and typing this thesis.

The Arctic Institute of North America, Montreal, April 1954, Svenn Orvig。 
TABLE OF CONTENTS

CHAPTER

I. INTRODUCTION TO THE PROBLEM . . . . . . . . 1 Research problem ............. . 4 Definitions of terms used ........ 8 Observations and instruments ....... 10

General outline of the work on the icecap . . 18 The Penny Icecap, its size and features . . 21 Climatic and glaciological conditions ... 24 Outline of the thesis ........ 31

II. THE WEATHER IN THE CUMBERLAND PENINSULA DURING

THE BUDGET YEAR 1952-1953 •. . . . . . 33

Surface data from Padloping . . . . . 33

Summary of weather in the Cumberland Peninsula during the summer of 1953 . . . . . 39

Precipitation in the Cumberland Peninsula during the winter of 1952-1953 . . . . 42

III. METEOROLOGICAL OBSERVATIONS ON THE PENNY ICECAP • 44 Temperature ............ . 44 Humidity ............. 83 Wind ............. 88 Pressure . . . . . . . . . . 96 Clouds, cloudiness and fog ....... 109 Precipitation ............ . 115 
CHAPTER

PAGE

IV. RADIATION MEASUREMENTS ON THE PENNY ICECAP • • 119

Duration of sunshine ........... 119

Total radiation from sun and sky ...... 126

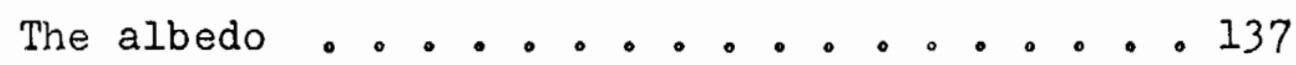

outgoing radiation . . . . . . . . . 141

V. ABLATION MEASUREMENTS ON THE PENNY ICECAP 。 • • 144

Ablation . . . . . . . . . . . . 149

Periods of ablation ........... 155

The budget year 1952-1953 on the Penny

Icecap . . . . . . . . . . . 157

A comparison of glaciers . . . . . . . 159

VI. THE HEAT EXCHANGE AT THE ICECAP SURFACE • $\bullet .168$

The heat exchange . . . . . . . . 169

Transfer of heat and water vapour through

the air. . . . . . . . . . . . . 172

VII. ABIATION AS A FUNCTION OF RADIATION AND

METEOROLOGICAL FACTORS . . . . . . . 180

The first main melting period . . . . . 184

The second main melting period . . . . . 188

The third main melting period . . . . . 190

Importance of radiation, convection and

conduction, and condensation . . . . . 192

Comparison with other investigations . . . 195 
CHAP'TER

PAGE

VIII. SUMLARY AND CONCLUSIONS • . . . . . . . . 200 Summary . . . . . . . . . . . . 200 Conclusions............. 206 TABIES I - XIII . . . . . . . . . . . . . 213 BIBLIOGRAPHY . . . . . . . . . . . . . . . 227 


\section{LIST OF TABLES}

TABLE

PAGE

1. Mean Monthly Temperatures, Cumberland Sound • - 26

2. Mean Monthly Precipitation, Cumberland Sound - - 26

3. Mean Monthly Cloudiness, Cumberland Sound • • 27

4. Mean Daily Temperature, Padloping . . . . . 33

5. Mean Daily Maximum Temperature, Padloping . . - 33

6. Mean Daily Minimum Temperature, Padloping . . . 34

7. Absolute Maximum Temperature, Padloping . . . 34

8. Absolute Minimum Temperature, Padloping . . . . 34

9. Mean Monthly Precipitation, Padloping . . . . 35

10. Monthly Precipitation 1953, Padloping . • . • 35

11. Wind, Percentage Frequency by Directions,

ten Year Period, Padloping . . . . . . . 36

12. Wind, Percentage Frequency by Directions,

1953, Padloping . . . . . . . . . . 36

13. Wind, Percentage Frequency by Speeds, ten

Year Period, Padloping . . . . . . . . . 37

14. Wind, Percentage Frequency by Speeds, 1953,

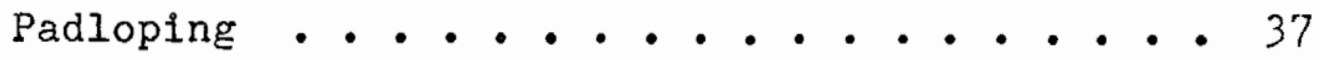

15. Wind, Percentage Frequency by speeds, for the

Summer Period, Padloping . . . . . . . . 37

16. Average Sky Cover, Padloping . . . . . . . 39

17. Monthly Precipitation, August-May, Padloping . . 43

18. Mean Temperatures for Different Periods . . . 45 
TABLE

PAGE

19. Mean Daily Maximum and Minimum Temperature • . - 47

20. Mean Temperatures, June . . . . . . . . 51

21. Mean Temperatures, July . . . . . . . . 51

22. Mean Daily Temperatures, Summer Period . . . - 51

23. Difference in Mean Temperatures at Base Camp and AI . . . . . . . . . . . 56

24. Temperature Gradients over the Surface . . . . 62

25. Mean Temperatures at Three Levels . . . . . 64

26. Lapse Rates over the Surface . . . . . . 65

27. Wind Direction and Mean Temperature at Three

Feet above Surface ...... . . . . 71

28. Mean Temperature Every Second Hour on Seven Days

with above Freezing Temperatures Only . . . 78

29. Mean Temperature Every Second Hour on Seven Days

with below Freezing Temperatures Only . . . 78

30. Wind Direction and Mean Relative Humidity at

Three Feet above the Surface . . . . . 86

31. Number of Observations, and the Percentage

Frequency of the Different Directions . . . 90

32. Wind Direction and Mean Wind Speed at Six Feet above Surface • • • • • • • • • • 92

33. Frequency of Different Wind Speed Intervals in

Percentages of the Total Number of Measurements 35

34. Cloudcover in Tenths of the Sky Covered . . . 111 
TABLE

PAGE

35. Wind Direction and Mean Cloudiness in Tenths of the Sky Covered ........... 112 36. Probability of Fog ........... 114 37. Probability of Fog with Different Wind Directions 114 38. Monthly Precipitation in Inches ....... 118 39. Probability of Rain, Drizzle, Snow and Hoar-frost ............ 118 40. Recorded Hours of Sunshine as Percentage of Possible Sunshine . . . . . . . . 122

41. Incoming Radiation and the Ratio $I_{10} / I_{0}$. . . 133 42. Ablation at Camp Al in Cms of Water ..... 154 43. Regime of the Penny Icecap . . . . . . . 159 44. Heat Supply and Percentage Importance . . . . 194 45. Percentage Importance of Different Factors in Ablation ............ 196

I. Mean Temperature for Each Day of Investigation . . 214 II. Five-Day Running Means of Mean Daily Temperature . 215 III. Daily Maximum and Minimum Temperature . . . 216 IV. Daily Range of Temperature . . . . . . . 217

V. Mean Daytime Temperature at Three Levels . . . 218 VI. Frequency of Different Temperature Intervals at the Three Levels in Percentages of the Total Number of Measurements ................ 219 
TABLE

VII. Mean Values of Temperature at Two-Hourly Intervals

from 0800 to 2000 at Three Levels . . . . 220

VIII. Mean Daily Values of Relative Hurnidity at Three

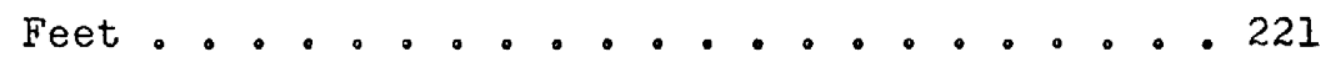

IX. Average Daily Wind Speed on the Icecap in MPH .222

X. Mean Daily Pressure at Camp Al . . . . . . 223

XI. Duration of Sunshine . . . . . . . . . 224

XII. Daily Incoming Radiation in $\mathrm{Cal} / \mathrm{cm}^{2}$. . . . . 225

XIII. Snow Depth in Inches . . . . . . . . . . 226 
1. Location Map ............. 12

2. The Mast ............. 16

3. The Icecap Camp . . . . . . . . . 17

4. Area of Investigation . . . . . . . . 20

5. R。C.A.F。 Photograph of Penny Icecap and Upper Coronation Glacier ......... 23

6. The Penny Icecap . . . . . . . . 25

7. Percentage Frequency of Wind by Directions, ten Year Period, Padloping . . . . . 38

8. Percentage Frequency of Wind by Directions, Summer, 1953 . . . . . . . . 38

9. Mean Daily Temperature and Five-Day Running

Means of Mean Daily Temperature . . . . 46 10. Daily Maximum and Daily Minimum Temperature . 48 11. Thermograph Traces for Two Weeks in July . . 50 12. Mean Temperature, June ......... 52 13. Mean Temperature, July . . . . . . . 53 14. Mean Daily Temperatures . . . . . . 55 15. Thermistors on Mast .......... 59 16. The Thermistor at Three Feet ........6 60 17. Niean Daytime Temperature at Three Levels ... 61 18. Frequency Distribution of Daytime Temperature . 68 
FIGURE

19. Mean Temperature at Two Hour Intervals at Three Feet . . . . . . . . . . . ....74

20. Ilean Temperature at Two Hour Intervals at

Thirteen Feet . . .......。. . 75

21. Mean Temperature at Two Hour Intervals at

Twenty-three Feet . . . . . . . . 76

22. Hean Temperature at Two Hour Intervals on some

Selected Days . . . . . . . . . . 79

23. Mean Daily Relative Humidity . . . . . . 87

24. Wind Directions for each Month and for Period - 91

25. Wind Speeds for Period . . . . . . . . 93

26. Pressure and Wind Speed . . . . . . . . 98

27. Weather Map, May 29th . . . . . . . . 101

28. Weather Map, June 6th . . . . . . . . 103

29. Weather Map, June 8th . . . . . . . . 104

30. Weather Map, June 12th . . . . . . . 105

31. Weather Map, June 14th . . . . . . . 106

32. Weather Map, July 14th . . . . . . . . 107

33. Weather Map, July 26th . . . . . . . 108

34. Cloudiness and Fog with Different Wind Directions 113

35. Hoar-Frost . . . . . . . . . . . 116

36. Duration of Sunshine . . . . . . . . 124

37. M.S.C. Type G Bimetal Actinograph . . . . 130

38. Kew Type Robitzsch Actinograph . . . . . . 131 
FIGURE

39. Incoming Radiation on Six Days ...... 136 40. Radiometers for Measurement of Albedo . . . . 139 41. The First Pit on the Barnes Icecap, 1950 . . 147 42. The First Pit on the Penny Icecap, $1953 \ldots 148$ 43. Periods of Ablation ........... 156 44. Accumulation = Ablation at the Firn Line, and Altitude of the Firn Line for Different Glaciers .......... . 162 


\section{INTRODUCTION TO THE PROBLEM}

The oldest known descriptions of glaciers are found in Icelandic literature from the llth century. Scientific studies of glaciers were first undertaken in Switzerland some five hundred years later, and during the 19th century glaciology became important in geology, as it was evident that the glaciers were instrumental in the evolution of landscape.

Regular meteorological service, with weather forecasting, was first established in France, where synoptic weather maps were published from 1863, but climatological research had been carried out before that date. It was realized that Alpine glaciers had varied much in extent, both in historic and prehistoric times, 1,2 and the study of the connection between fluctuations in climate and variations of the size of glaciers became an important part of physical geography

Step by step the science of glaciology was pursued in other parts of the world: Norway, Sweden, Iceland; and then in the more remote lands: Alaska, Spitsbergen, Greenlando Often the results of glaciological research were reported in geological publications and at geological conferences. The geologist's

I R.F. Flint, Glacial Geology and the Pleistocene Epoch. New York: John Wiley \& Sons, Inc., 1947, pp. 2-6。

2 E. v Drygalski and F. Machatschek, Gletscherkundè。 Wien: Franz Deuticke, 1942, pp. 1-4. 
interest in the study of glaciers is easily understood when one adopts definitions like those of v. Klebelsberg: "Gletscherkunde" (glaciology) has to do with the glaciers of the present day; "Glazialgeologie" with those of the past. ${ }^{3}$ Only when the two problems are connected can one obtain a knowledge of the importance of the glaciers on the changing face of the earth.

A great deal of work is still being done on problems of a descriptive nature: morphological investigations, movement of glaciers and variations of their margins. The more recent research in glaciology is of a different character: the investigation of the physical processes involved in the life of a glacier. This work started in Sweden, 4 and Scandinavian scientists have been pioneers in this field. The study of climatic fluctuations, as shown by the behaviour of glaciers, necessitates a knowledge of the relationship between the meteorological elements and the accumulation and ablation. Radiation measurements are also of the utmost importance in a detailed study of a glacier's regime, and only in recent years have reliable and reasonably accurate radiation instruments been used in the field.

A complete historical survey of glaciological research would, today, be a considerable undertaking; references will therefore only be made to investigations of direct interest in

3 R. v。 Klebelsberg, Handbuch der Gletscherkunde und Glazialgeologie. Wien: Springer Verlag, 1948, Preface。

4 A. Hamberg, "Zur Technik der Gletscheruntersuchungen," Comptes Rendus IX Congres geol. internat. de Vienne 1903. Wien, 1904. 
the present work. In Greenland a large number of explorers and scientists have studied the meteorology and glaciology of the Inland Ice (see BIBLIOGRAPHY: Belknap, Expeditions Polaires Francaises, Freuchen, Georgi, Hobbs, Holzappel, Kopp, Lindsay, Loewe, Maurstad, Mirrlees, Mohn, de Quervain, Sorge, Wegener), but the published results have dealt with general meteorological and glaciological observations, without attempting to evaluate the influence of the different meteorological factors on the glacier regime, a program emanating from an interest in the more meteorological aspect of the science. The investigations of interest in this study are mainly those carried out in the past thirty years around the northern-most parts of the Atlantic. Ahlmann summarized this work in his paper of $1948,{ }^{5}$ listing geomorphological studies in Norway, the Swedish-Norwegian Arctic Expedition of 1931, the Norwegian-Swedish Spitsbergen Expedition in 1934, the Vatnaj8kull investigations in 1936-38, and the North-East Greenland Expedition in 1939-40. The Karsa Glacier studies of 1925-26 were continued from 1942, and further work has been done in northern Sweden, in the Kebnekajse Massif, and also in Norway.

Gradually, as these investigations were undertaken, the problems became more precisely defined, and lately other workers have taken up the challenge in other parts of the world, using

5 H. W:son Ahlmann, "Glaciological Research on the North Atlantic Coasts," Royal Geographical Society Research Series, No. $1,1948$. 
the methods elaborated largely by Ahlmann and Sverdrup.

\section{RESEARCH PROBLEM}

Statement of the problem. It was the purpose of this study to (1) describe the meteorological conditions on the Penny Icecap during the period from the latter half of May to the first half of August 1953; (2) compare these conditions with those observed on the Barnes Icecap by the author during the ablation period of 1950; (3) calculate the heat balance at the snow surface and to show the relationship between ablation and meteorological conditions; and (4) compare the results with similar investigations in other localities in the northern Hemisphere.

Importance of the study. Before 1950 nothing was known about the climate of the ablation period on any Canadian glacier or icecap. 6 Wood noted that previous to 1948 it was difficult to recall a single example of studies carried out in North America and devoted to the great areas of snow accumulation.7

A closer understanding of the laws governing the behaviour of glaciers necessitates cooperation between glaciologists and meteorologists, since the problems of the two fields go hand in hand -- precipitation with alimentation of the glaciers, interior temperatures of ice and firn with air temperatures. As pointed

6 S. Orvig, The Climate of the Ablation Period on the Barnes Ice-Cap in 1950 , thesis submitted for the degree of M.Sc., McGill University, $1951, p$. 3.

7 W. A. Wood, "Project Snow Cornice", Arctic, Vol. I, No. 2, Autumn, 1948, p. 107 
out by Ahlmann, glaciology requires meteorological observations of a special kind. ${ }^{8}$ General and local climatological information is necessary to determine the ablation, with observations from the glacier surface itself. The investigations, during the past thirty years, in the regions round the northern-most parts of the Atlantic were undertaken partly to determine the behaviour of glaciers in a changing climate, partly to obtain a more detailed knowledge of the importance of the different meteorological factors in the process of ablation. They have been carried out during a period with receding glaciers. Similar investigations have been lacking from other parts of the world; particularly has the knowledge of radiation at high altitudes been unsatisfactory.

It was desirable to study how the regime of glaciers and its governing factors differ in other areas when approached along the lines followed on the Norwegian-Swedish Spitsbergen Expedition in 1934,9 and the same methods have therefore been applied to observations from Iceland, 10 from the Frolya Glacier on Clavering Island on the east coast of Greenland, 11 from a glacier in northern

$8 \mathrm{H}$.W:son Ahlmann, "Glaciological Methods," The Polar Record, Vol. IV, No. 31, January, 1946, p. 316.

$9 \mathrm{H}$. W:son Ahlmann, H. U. Sverdrup and H。 Olsson, "Scientific Results of the Norwegian-Swedish Spitsbergen Expedition in 1934, Parts 1-8," Geografiska Annaler, Vol。XVII, 1935, and Vol. XVIII, 1936.

$10 \mathrm{H}$. W: son Ahlmann and S. Thorarinsson, "Vatnajokull, Scientific Results of the Swedish-Icelandic Investigations 193637-38, Chapters I-XI", Geografiska Annaler, Vol. XIX, 193', Vol. XX, 1938; Vol.XXI, 1939, Vol.XXII, 1940, and Vol.XXV, 1943.

ll B. Eoriksson, "Meteorological Records and the Ablation on the Froya Glacier in Relation to Radiation and Meteorom logical Conditions," Geografiska Annaler, Vol. XXIV, 1942, pp. $23-50$. 
Sweden, ${ }^{12}$ in north Greenland, 13 and in the Antarctic 14,15 From a recent review of the most conclusive results it is evident that the relative importance of the climatic elements varies from one region to another. 16.

In North America glacial studies have been undertaken for many years, particularly in Alaska and the Rocky Mountains, lately (in 1952 and 1953) on the Saskatchewan Glacier in Banff National Park, but these studies have been dealing mainly with the extension of glaciers: their advances and recessions. Geomorphological and botanical evidence has been used in working out the history of glacier fluctuations; ${ }^{17,18,19}$ nothing has yet been published

12 C.C. Wallen, "Glacial-Meteorological Investigations on the Karsa Glacier in Swedish Lappland, 1942-1948," Geografiska Annaler, Vol. XXX, Haft. 3-4, 1948, pp. 451-672.

13 B. Fristrup, "Climate and Glaciology of Peary Land, North Greenland," Assemblee Generale de Bruxelles, U。G.G.I.2 1951, Tome I, Louvain, 1952, pp. 185-93.

14 G. Robin, "Queen Maud Land: The Scientific Results of the International Expedition," The Geographical Magazine, Vol. $\mathrm{XXV}$, No. 6, 1952, $\mathrm{pp} .283-93$.

15 F. Loewe, "Glaciological Work in Terre Adelie in 1951: Preliminary Report," The Journal of Glaciology, Vol. 2, No. 14, Nov. 1953, pp. 248-49.

16 C. C. Wallen, "Influences Affecting Glacier Extension in Northern Sweden," Assemblee Generale de Bruxelles, U.G.G.I., 1951, Tome I, Louvain, 1952, p. 149.

17 D. B. Lawrence, "Glacier Fluctuations in Northwestern North America within the past six Centuries," Assemblee Generale de Bruxelles, U.G.G.I.2 1951, Tome I, Louvain, 1952, pp. 161-66.

18 D. B. Lawrence, "Glacier Fluctuation for Six Centuries in Southeastern Alaska and Its Relation to Solar Activity, "The Geographical Review, Vol. 40, No. 2, 1950, pp. 191-223.

19 L. E. Nielsen and A. S. Post, "The Castner Glacier Region, Alaska," The Journal of Glaciology, Vol. '2, No. 14, Nov. 1953, pp. 277-80. 
on glacial-meteorological studies. The same is the case with respect to the recent investigations of the Grinnell Icecap in southern Baffin Island. This icecap occupies the summit of the highland between Hudson Strait and Frobisher Bay, and was investigated in the years 1927, 1929 and 1931,20 and again in 1937 by members of MacMillan's expedition. 21 Mercer and Blake from McGill University studied this icecap in 1952, and Mercer again in 1953,22 but the meteorological observations included only temperature and precipitation. Some recent work on glacialmeteorological problems has been attempted in North America, such as that done on Project "Snow Cornice" on the Seward. Malaspina Glacier System on the Alaska-Yukon boundary, in 1948, 1949 and 1951; and on the Juneau Ice Field Research Project, yearly since 1948. On the latter expeditions efforts have been made to obtain an actual determination of the total heat exchange at the surface of glaciers in the area, $23,24,25$ but no

20 S. K. Roy, "The Grinnell Ice-Cap," Geol. Ser. Field Museum of Natural History, Vol. 7, No. 1, 1937, pp. 1-19.

21 S. K. Roy, "Additional Notes on the Grinnell Ice-Cap," Geol. Ser. Field Museum of Natural History, Vol. 7, No. 4, 1938 , pp. 59-69.

22 W. Blake, "Studies of the Grinnell Glacier, Baffin Island," Arctic, Vol. 6, No. 2, 1953, p. 167.

23 F. Pooler, "Brief Discussion of some theoretical Aspects and Recommendations for future Meteorological Studies," Juneau Ice Field Research Project, Report No. 6, 1952, p. 99.

24 Personal information from $C$. Jo Heusser, American Geographical Society, and $R$ 。C. Hubley, Department of Meteorology and Climatology, University of Washington.

25 R. C. Hubley, "Preliminary Report on Meteorological and Glaciological Studies on Lemon Creek Glacier," Progress Report, J.I.F。R०P०, 1953, p. 16 . 
final results have been published as of March, 1954. Some prew liminary interpretations have been rade, but the full analysis has been left for a later date. 26 Hare noted that the meteorological results of the Arctic Institute Baffin Island Expedition of 1950 constitutes the first direct attempt at glacial-climatological work in eastern Canada. 27

Because the study of North American glaciers has been restricted to general descriptions of form and location, glaciological research according to modern geophysical principles has been given a high place in the research program of the Arctic Institute. Such research might cast some light upon the glacier conditions in Canadian arctic regions and supplement similar earlier work in other locations. The 1950 Expedition to the Barnes Icecap was therefore followed by the 1953 Expedition to another large ice area in Baffin Island. The meteorological observations from these two expeditions present a picture of the climatic conditions during the ablation period on two icecaps. Thereby an increased understanding of the nature of some Canadian icecaps is obtained.

\section{DEFINITIONS OF TERMS USED}

Ablation. The joint result of the processes consuming a

26 M. M. Miller, "1951 Winter Season", Juneau Ice Field Research Project, Report No. 8, 1953, Foreword.

27 F. K. Hare, "Recent Investigations into the Distribution of Snow and Ice in Eastern Canada," Assernblee Generale de Bruxelles, U。G.G.I. 1951, Tome I, Louvain, 1952, po 17I. 
snow or ice surface, in the first instance: melting and evaporation. The wind also removes snow, and calving of the glacier front must also be considered as ablation. The greater part of the ablation takes place; on the surface, but internal ablation (in crevasses and tunnels) can be important. The ablation area is that part of a glacier where the ablation is larger than the accumulation.

Gross ablation. The total quantity of melting, evaporation, wind corrasion, calving.

Net ablation. The amount of water actually lost to the glacier by drainage, evaporation, calving and corrasion. The difference in gross and net ablation is due to the re-deposition of water in lower layers, and the transport of snow from one place to another.

Accumulation. The joint result of the processes adding to a glacier surface: snow, hail, hoar-frost, rime, drifting snow. Also rain that is not drained off. The accumulation area is that part of a glacier where the accumulation is larger than the ablation.

Budget year. The period, at the firn line, from first snowfall of winter through the ablation season of the following summer.

Firn line. The firn line is the highest level on a glacier to which a winter snow cover recedes during the following ablation 
season. The firn line (zone) separates the accumulation area from the ablation area. At this limit the year's total accumulation equals its total ablation. If there is superimposed ice the firn line is the lower limit of the superimposed ice.

Firn. Old, granular, compacted snow, covering the surface of the accumulation area (neve area) throughout the year.

Regime of a glacier. The grand total of its entire accumulation and net ablation during a budget year. If in a budget year the accumulation volume is larger than that of the ablation, the regime is positive; otherwise it is negative.

Summer, or suminer period. For the 1950 Expedition: the three months of June, July, August. For the 1953 Expedition: from the middle of May to the middle of August.

\section{III。 OBSERVATIONS AND INSTRUMINTS}

In the summer of 1950 the Arctic Institute of North America sponsored the first Baffin Island Expedition. The expedition members studied biology, geology and sea ice in the area around Clyde $\left(70027^{\prime} \mathrm{N}-68031^{\prime} \mathrm{W}\right)$, and also glaciology and meteorological conditions on and at the edge of Barnes Icecap. The glaciological work was carried out by the expedition leader, P。D。Baird, and by $W_{0} H_{0}$. Ward of the United Kingdom Department of Scientific and Industrial Research, at times assisted by others. The meteorow logical observations on the icecap were carried out by the author, 
who spent ninety-two days at the Main Camp. This carnp was called A-l.

The second Baffin Island Expedition was in the field in the Cumberland Peninsula area from May till September 1953, and worked along similar lines to the previous expedition. ${ }^{28}$ The general areas of investigation are shown in Figure 1 , in which also the Department of Transport weather stations are indicated。 29 The glaciological work was carried out by W.H. Ward and P. D. Baird, assisted by B. H. Bonnlander of McGill University. Radiation measurements were made on the icecap by Ward and the au'hor; seismic soundings were made by other expedition members on the icecap and on one of the outflowing valley glaciers. The meteorological observations on the icecap were carried out by the author, who spent eighty-six days at the icecap camp. This camp will be known as Camp Al.

The glacier-meteorological studies on the Penny Icecap were planned to include (1) the regime of the icecap, in an attempt to find the causes for the probable yearly variations of the regime; (2) the ablation at Camp Al; (3) the meteorological conditions at Camp Al, both at the surface and at different levels above the surface, in an attempt to determine the importance of

28 P. D. Baird, "Baffin Island Expedition, 1953, A Preliminary Field Report," Arctic, Vol. VI, No. 4, 1953.

29 The station on Padloping Island was established by the United States Air Force in 194I, and operated by U. So personnel until October 1953. It was then taken over by the Royal Canadian Navy. The operation of the station will later be transferred to the Federal Department of Transport. 


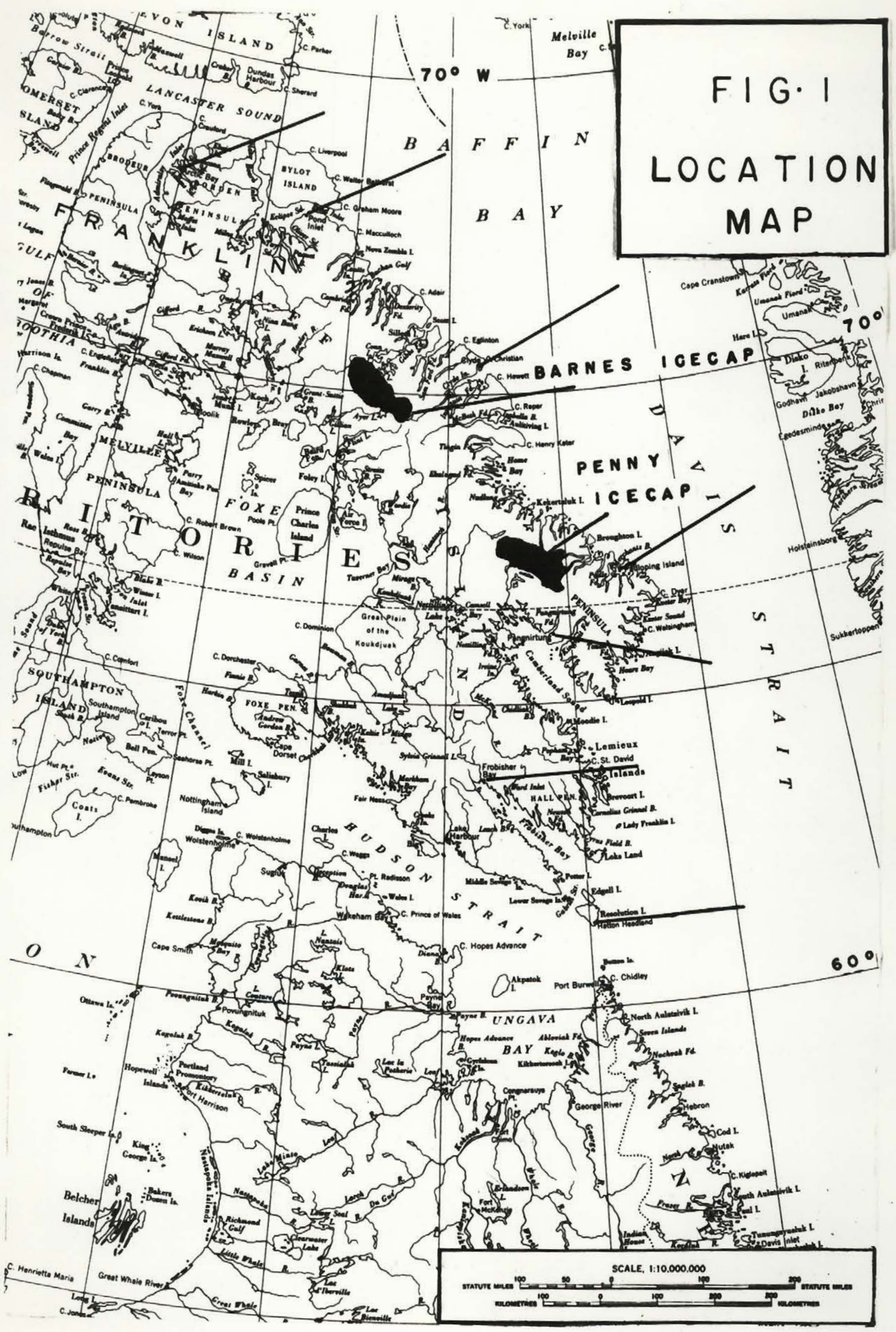


the different meteorological factors in the ablation process; and $(4)$ as complete a study of radiation as possible, both as a general study of high-altitude radiation in the Arctic, and to be used in a study of the heat exchange at the icecap surface.

Character of the observations. The icecap station was established on May 16th, and from May 21st to August 9th the following meteorological observations were carried out every two hours from 0800 to 2000 daily: pressure by aneroid; temperature at three, thirteen and twenty-three feet above the surface; humidity at three feet, by aspirated hygrometer; wind speed and direction at six feet; also observations of clouds, cloudiness, fog, visibility and ceiling. Three times per day, at 0800, 1400 and 2000, maximum and mininum temperatures and precipitation were measured. Snowfall was measured by stakes, rain by means of an ordinary rain-gauge. Duration of sunshine was recorded by a Campbell-Stokes recorder, and a barograph and a thermo-hygrograph gave continuous records of pressure, temperature and rela a. tive humidity at three feet above the surface for eighty-one days. Continuous recordings of incoming short-wave radiation were made for eighty days with two bimetal actinographs; and spot measurements of net radiative flux and of incoming and outgoing short-wave radiation were made on numerous occasions with spew cially constructed radiometers.

Instruments. The following instruments were kindly sup. plied by Mr.A. Thomson, Controller, Meteorological Division, 
Department of Transport, Toronto: two MSC maximum thermometers (ELLIOTT-26108 and ELIIOT'-F27958, both with correction cards); two MSC minimum thermometers with correction cards (the one used: TAYLOR-2990274); and a MSC TYPE G Bimetal Actinograph for the continuous recording of total solar and sky radiation received on a horizontal surface over the period of a day. From the Department of Transport weather station at Frobisher Bay, Baffin Island, the expedition obtained a standard U。S。 Weather Bureau instrument screen.

From the Montreal Office of the Arctic Institute the fol lowing instruments were available: one compensated pocket aneroid, reading pressures from 21 to 31 inches; one CASELIA ASSMANI aspirated hygrometer, with dry bulb thermometer No. 31367 and wet bulb thermometer No. 31387; one Short and Mason anemometer No. 1-849, with correction card; one Short and Mason seven day barow graph No. E 12651; one Short and Mason seven day thermo-hygrograph No. L 1647; one standard 12 inch rain gauge and graduate.

From the Department of Geography, McGill University: one Campbell-Stokes sunshine recorder.

Air temperatures at thirteen and twenty-three feet were measured by thernistors placed on a collapsible aluminium mast, twenty-three feet high, which was erected at the icecap station. Leads from the thermistors were carried into the living tent, where the temperatures were read on one of two portable calibrated Wheatstone bridges. The same Wheatstone bridges were used to read the temperatures from similar thermistors buried at various 
depths in the snow and firn. The Wheatstone bridges were made and calibrated by Ward at the $U$ 。 $K$. Department of Scientific and Industrial Research, where he also calibrated all thermistors used on the expedition. Ward also brought from England a new KEW TYPE Robitzsch Binetal Actinograph for additional continuous recording of the incoming short-wave radiation; and further a GIER and DUNKLE TYPE blown plate radiometer for measurements of the net radiative flux, and two specially constructed radiometers for measurements of both incoming and outgoing short-wave radiation. These three instruments were constructed and calibrated by Ward, using thermistors for the sensitive elements。 Wind direction was observed by a wind vane on top of the mast. The instrument screen faced North, and its bottom was kept two feet above the snow surface. It housed a mercury themometer, maximum and minimum thermometers and the thermo-hygrograph。

The sunshine recorder was placed on top of the screen, levelled off in all directions and the latitude scale set for $67^{\circ} \mathrm{N}$ (latitude of the icecap station: $66^{\circ} 58^{\circ} 30^{\prime \prime} \mathrm{N}$ ).

The aneroid and the barograph were kept in the living tent.

The aluminium mast is shown in Figure 2 , and a diagram of Camp Al in Figure 3.

At the Base Camp in Pangnirtung Pass continuous weather observations were taken throughout the summer。 30 Several observers cooperated in the work; the instruments and results will be dis No. 4, 1953 . 
$-16-$

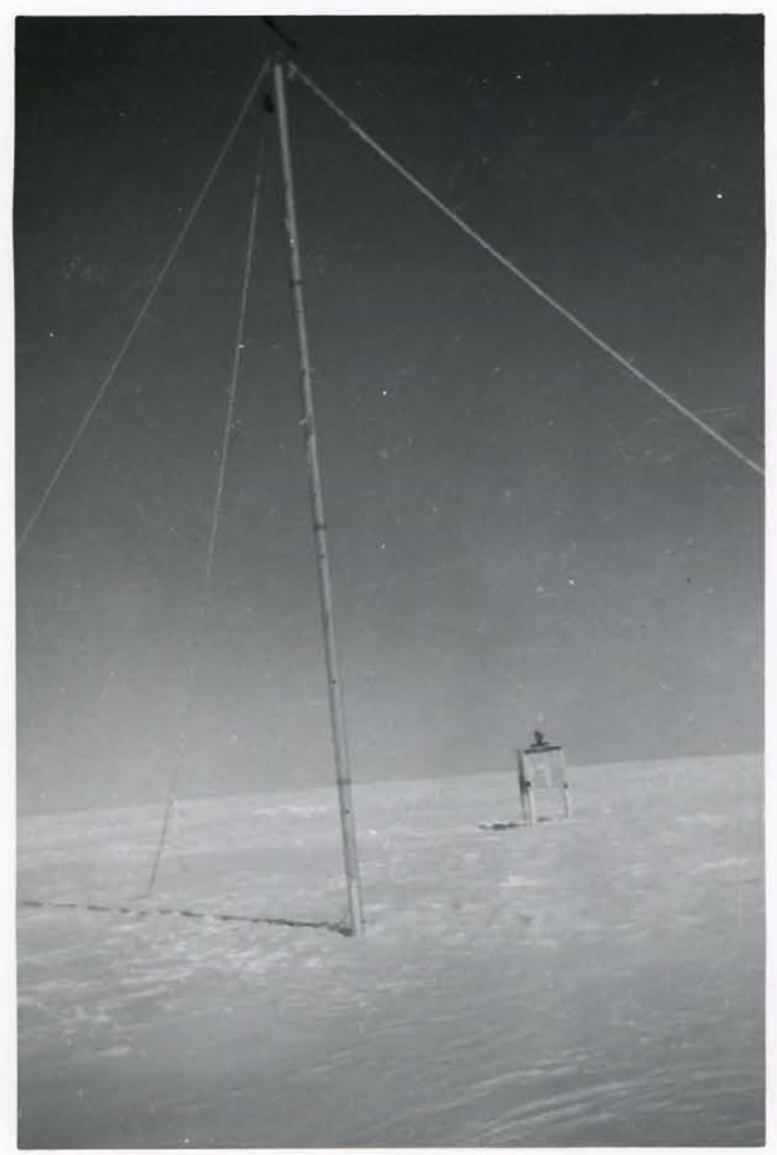

Fig. 2. The Mast. 
Nol

ABLATION STAKE

$$
\int_{1200^{\circ}}
$$

o MSclactinograph

Q e.

O KEM ACTINOGRAPH

I

$40 !$

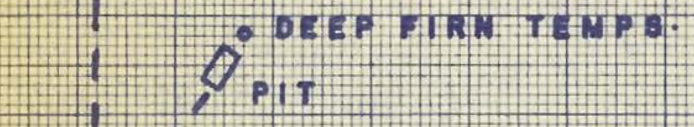

\section{FIG 3}

THE ICECAP CAMP

LAT. $66^{\circ} 58^{\prime} 30^{\prime \prime} \mathrm{N}$ LONG. $65^{\circ} 28^{\prime} W$ ALT. $6725^{\circ}$ asl.
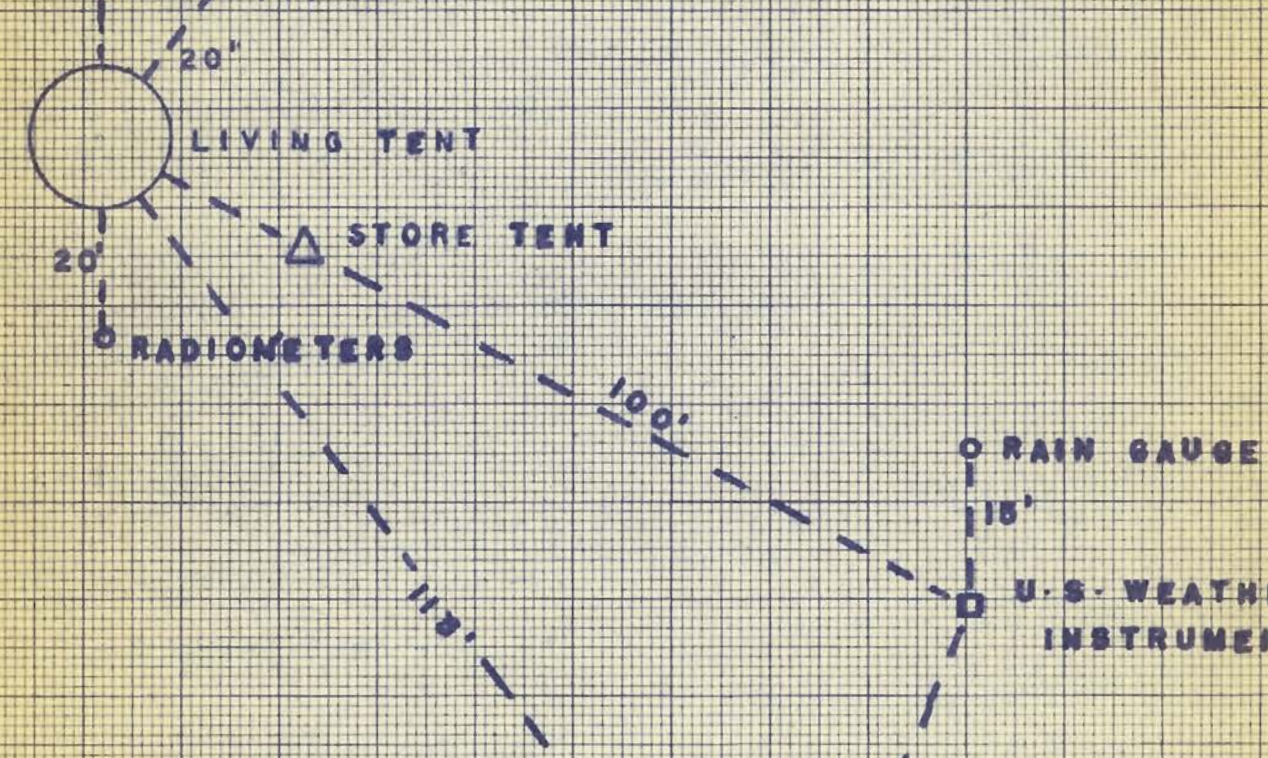

U.s- wearmen euneau

INGTRUEET SOREEN

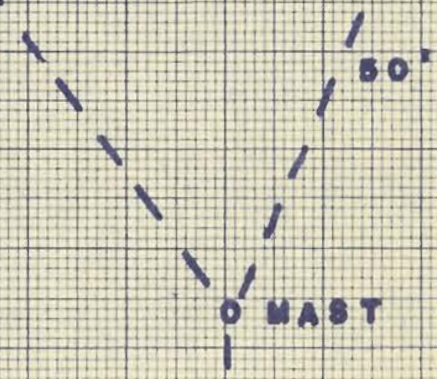

$100^{\circ}$

¿No 2 ablation btake

- rinatemas. 
cussed by Bonnlander. The records have been made available to this author for the purpose of the present study.

IV。 GENERAL OUTLINE OF THE WORK ON THE ICECAP

Baird, ward and the author took off from Pangnirtung on Way lóth in the expedition's chartered ski-equipped Norseman aircraft, piloted by $G$. Ingebrigtson. After less than one hour's flying, the aircraft landed on the highest icecap dome in clear and calm weather, and Camp Al was established at an altitude of 6725 feet $(2050$ meters) above sea level. The remainder of the meteorological instruments were brought in on May $18 \mathrm{th}$, and from Ivay 2lst to August 9 th observations were carried out every second hour from 0800 to 2000 daily. The last flight to the icecap station took place on May 24th, and on May 25th a reconnaissance flight was made around the icecap, but without landing at Al. The aircraft left Pangnirtung for Churchill on May 26th, and the party was on its own: skis and man-hauled sleds were the means of transportation for the rest of the season.

During the first week ablation stakes were planted near the camp, and Ward commenced the work of installing thermistors at different depths in the firn. Pits were dug and thermistors for firn temperature measurements placed in drill holes down to $69 \frac{1}{2}$ feet below the surface. These thermistors were read throughout the summer until the camp was evacuated in August.

On June 14th Baird arrived at Camp Al to relieve Ward in the glaciological work. On June 23rd J. Thomson, the expedition 
photographer, arrived at the camp; he and Ward left two days later for Camp A2. Baird continued glaciological work at the icecap camp, while Ward did the same at different locations from Camp $\mathrm{A} 2$, at the head of Highway Glacier, down to Base Camp in Pangnirtung Pass. ${ }^{31}$ In this area the Swiss members also worked。 doing seismic depth soundings to determine the thickness of firn and ice. ${ }^{32}$ The positions of the different camps are shown in Figure 4, which shows the area of investigation.

On June 27th Baird went on skis towards the western part of the icecap, reporting on his return that Camp AI was located on the highest dome of the icecap.

By June 24th the snow surface was melting at an altitude of 3400 feet, whereas at Camp Al only short, interrupted periods of melting took place. The longest ones lasted about sixty hours, commencing on July 13 th and on July 23rd. Although rain occurred on several occasions in July, snowfalls were nevertheless frequent, during the whole observation period, and the firn was refreezing downwards from the surface and upwards from below for several days before the camp was evacuated.

Baird left Camp AI on July 12th, and the next norning vard arrived back after seventeen days of glaciological work at numers ous sites between Camp Al and Base Camp in Pangnirtung Pass。 1953.

31 W. H. Ward, "Glacier Physics," Arctic, Vol. VI, No. 4. $32 \mathrm{H}$. Rothlisberger, "Seismic Sounding," Arctic, VoI. VI, No. $4,1953$. 


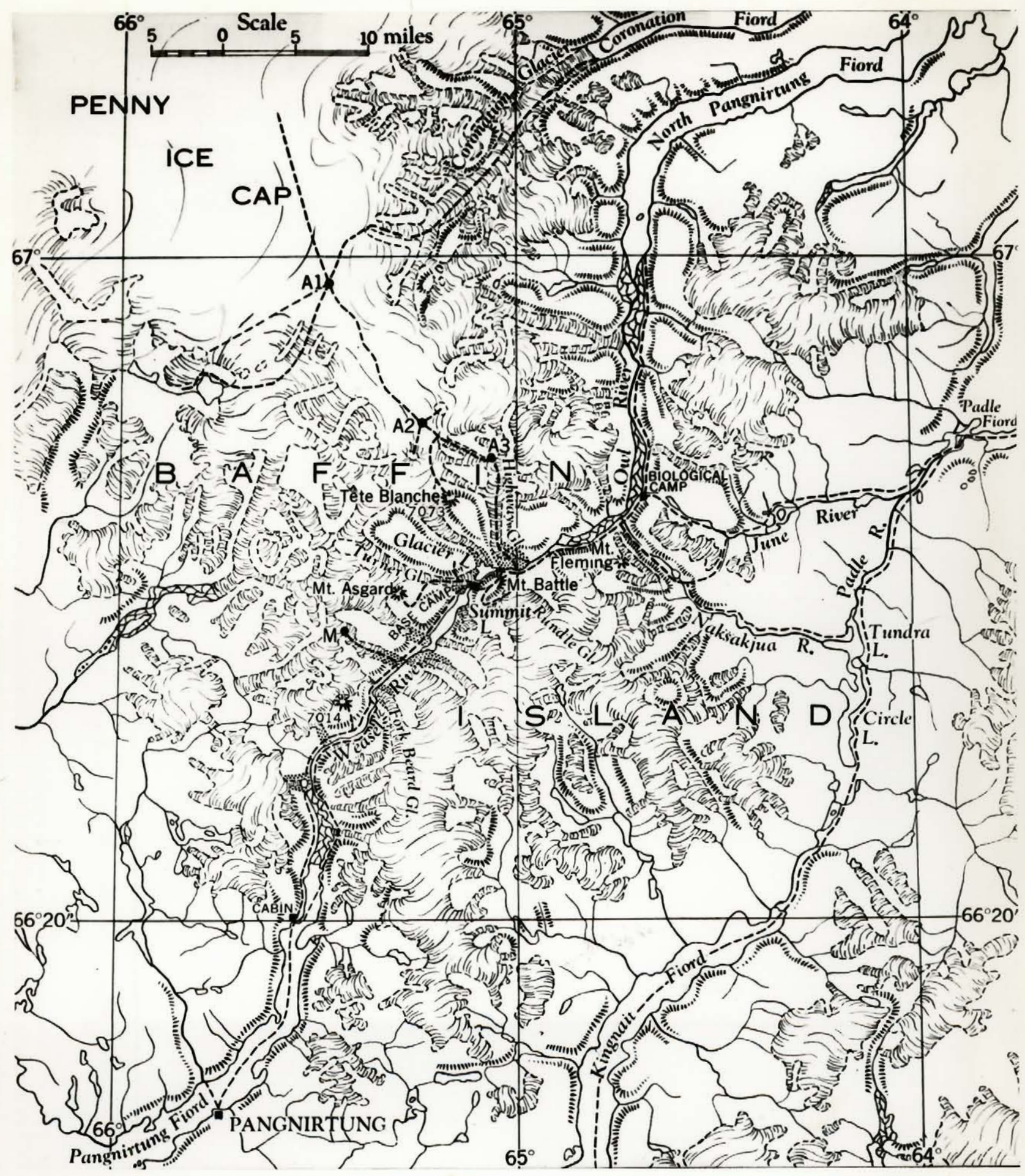

Fig. 4. Area of Investigation. 
On August 8th J. Marmet and B. H. Bonnlander arrived at Camp Al to help in evacuating, and on August 10th the icecap camp was abandoned, after eighty-six days occupation, with eighty-one days of continuous meteorological and glaciological observations. The investigations at times suffered from adverse weather conditions; fog, hoar-frost, winds and blowing snow sometimes made even the routine observations difficult or impossible to carry out.

\section{THE PENNY ICECAP, ITS SIZE AND FEATURES}

The Barnes Icecap has been described by members of the 1950 Expedition; 33 the other large ice area in Baffin Island, the Penny Icecap, lies in one of the most spectacular districts of the Arctic, and it is considerably higher than the Barnes Icecap. The first white man to sight Cumberland Peninsula was John Davis, who landed there in 1585. Since then the coasts and harbours have become familiar to whalers from Scotland and New England, but the inland has remained practically unknown. The German anthropologist Boas was there in 1883-84, and in the twentieth century J. D. Soper and I. J. Weeks worked there, 34 but nothing had been done on the valley glaciers and the icecap itself。

Pangnirtung Pass cuts through the mountain region of Cum. berland Peninsula, and the Penny Icecap extends northwestwards

\footnotetext{
33 S. Orvig, "The Climate of the Ablation Period on the Barnes Ice-Cap in 1950," Geografiska Annaler, XXXIII, Vol。33, Ht. 3-4, 1.951, p. 172.

34 P。D。Baird, "Cumberland Peninsula of Baffin Island," Canadian Geographical Journal, Vol. 48, No.3, March, 1954.
} 
from Pangnirtung Pass for some ninety miles, and is about twenty miles wide. It is bounded on the northeast and southwest by straight valleys partly filled with glaciers from the icecap and partly with ice-dammed lakes. It covers about 2300 square miles, almost identical with the area of the Barnes Icecap to the North. Its long axis curves in a southeast-northwesterly direction, along the presumed summit of the underlying mountains. In many respects it is quite different from the Barnes Icecap. The ice generally appears to be a few hundred feet thick, and it consists of a series of domes connected by broad valleys which spill relatively thick ice into more than a dozen large valley glaciers, at least ten of which are of major significance. The outer domes frequently terminate in ice cliffs, only one to two hundred feet in height, above three thousand foot rock walls which form the valiey glacier troughs.

One glacier on the north side, and two glaciers on the northeast side, reach sea level in the heads of fiords. The largest is Coronation Glacier, two miles wide and more than twenty miles long. Figure 5 shows ice cliffs on rock walls overlooking Coronation Glacier.

The icecap camp was located on the highest dome, 6725 feet above sea level, near the southeast end of the icecap, and in position $66^{\circ} 58^{\prime} 30^{\mathrm{mN},} 65^{\circ} 28^{\prime} \mathrm{W}$. From there the general level of the icecap decreases towards the northwest to an elevation of about two thousand feet. Southwards from the southeast end of 


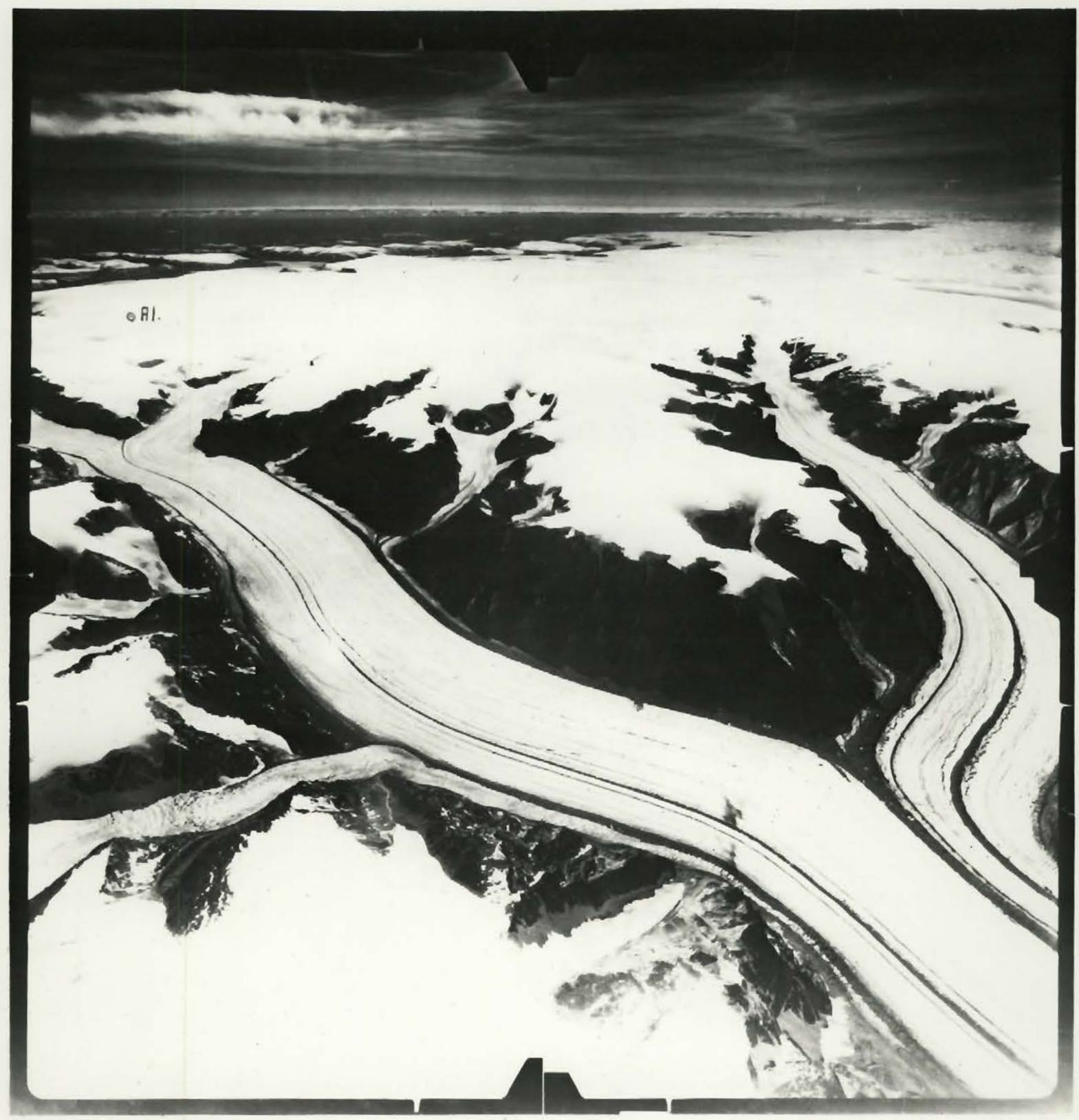

Fig. 5. R.C.A.F. Photograph of Penny Icecap and Upper Coronation Glacier 
the icecap lies the ten mile long Highway Glacier, one of three glaciers that flow into Pangnirtung Pass. This glacier was used as a ski route between Base Camp and Camp Al. Glaciological research was concentrated at Camp AI and at numerous sites between there and Base camp, along this route. 35

The whole area was photographed from the air by the Royal Canadian Air Force in 1948 and 1949, and a preliminary edition of the new National Topographic Series map was ready in 1951 on a scale of eight miles to one inch. This map was used by the members of the expedition. Base Camp was located at 1300 feet, Camp Al at 6725 feet, Camp A2 at 6300 feet, Camp A3 at 3314 feet。 and the lowest ablation stake at 1443 feet. Figure 6 shows the Penny Icecap with Camps AI and A2.

No high land was close to Camp Al. The distance to the highest mountains, which rise to seven thousand feet over Pangw nirtung Pass, is more than fifteen miles.

\section{VI。 CLIMATIC AND GLACIOLOGICAL CONDITIONS}

In order to understand the glaciation conditions in the area something must be said about the climatic conditions as far as they are known. The only two stations on the Cumberland Peninsula with weather records for several years are Pangnirtung $\left(66^{\circ} 09^{\prime} \mathrm{N}, 65^{\circ} 44^{\prime} \mathrm{W}\right)$, with records from 1930 to 1942 , and Padloping Island $\left(67^{\circ} 06^{\prime} \mathrm{N}, 62^{\circ} 21 \mathrm{~W}\right)$, with records from 1941. 1953.

35 W. H. Ward, "Glacier Physics," Arctic, Vol. VI, No. 4. 


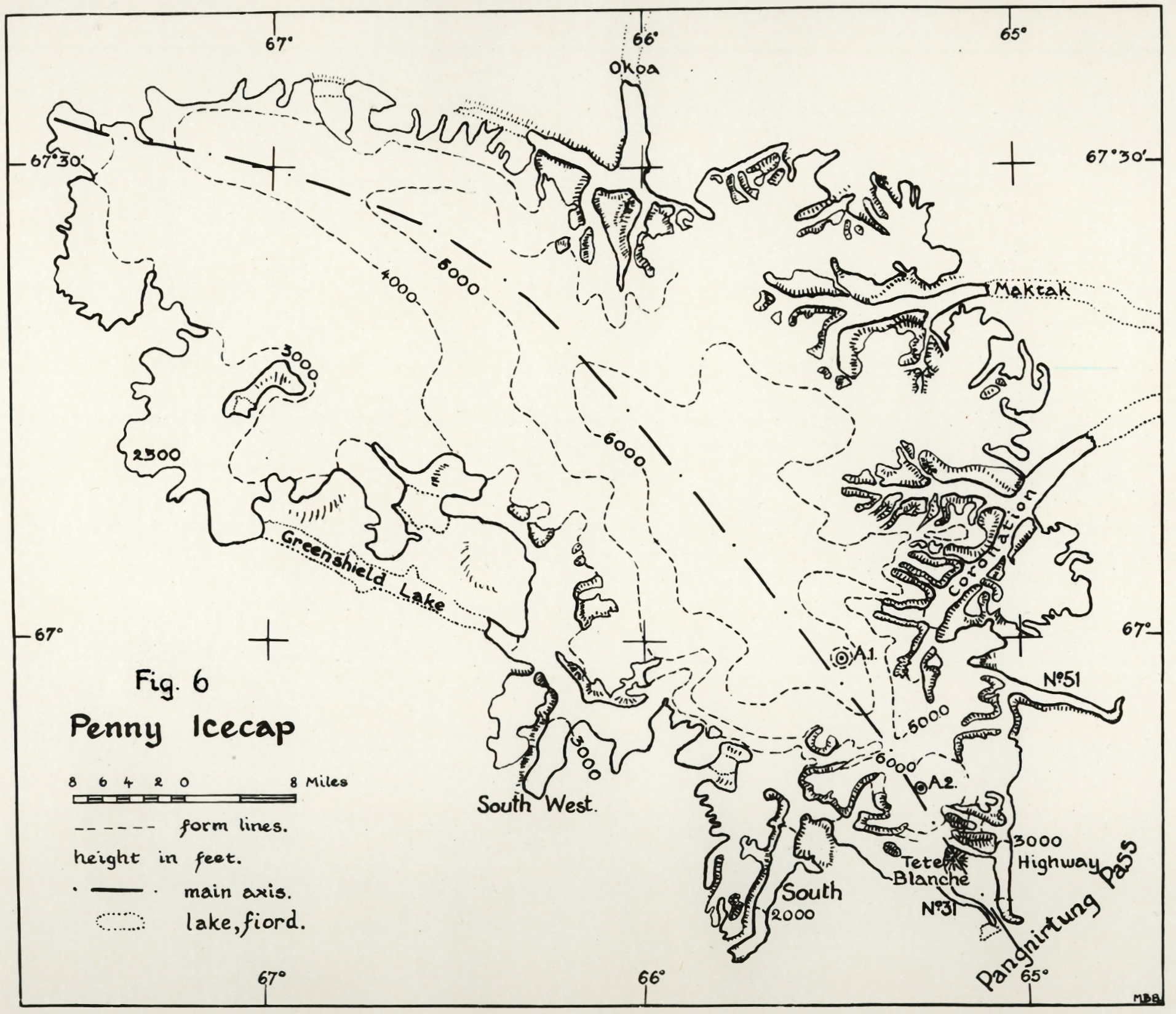


Older sources give a few references to weather observations in this area, but these are scattered and of short duraw tion. In general, these sources treat the climatic conditions of large regions, $36,37,38$ and do not describe in detail the local climates, which often vary considerably over relatively short distances。

Observations from Kingua Fiord, now called Clearwater Fiord, in the years 1877-78 (the Howgate Expedition) and 1882-83 (the German Polar Year Station) give the following means for temo perature, precipitation, and cloudiness. 39

TABLE 1

MEAN MONTHLY TEMPERATURES, CUMBERLAND SOUND $\begin{array}{ccccccccccc}\mathrm{J} & \mathrm{F} & \mathrm{N} & \mathrm{A} & \mathrm{M} & \mathrm{J} & \mathrm{J} & \mathrm{A} & \mathrm{S} & \mathrm{O} & \mathrm{N} \\ -20.2 & -24.9 & -9.4 & 7.9 & 28.4 & 35.8 & 42.4 & 42.4 & 35.6 & 20.6 & 3.3\end{array}$

$$
\begin{array}{ccc}
D & \text { Year } & \text { Range } \\
-9.5 & 12.7 & 67.3
\end{array}
$$

TABLE 2

MEAN MON'SHLY PRECIPITATION, CUMBERLAND SOUND

$\begin{array}{ccccccccccc}J & F & M & A & M & J & J & A & S & 0 & N \\ 0.31 & 0.31 & 0.55 & 0.51 & 0.75 & 2.28 & 3.39 & 1.18 & 2.17 & 0.59 & 0.91\end{array}$

$$
\begin{array}{ll}
D & \text { Year } \\
0.75 & 13.7
\end{array}
$$

36 Contributions to our Knowledge of the Meteorology of the Arctic Regions. Published by the Authority of the MeteoroIogical Council. Parts I to IV. London, 1879-85. gart, 1911.

$37 \mathrm{~J}$. Hann, Handbuch der Klimatologie, Band III, Stutt-

$38 \mathrm{~F}$. Baur, "Das Klima der bisher erforschten Teile der Arktis," Arktis, Vol. II, Heft 3,4, 1929.

39 H. U. Sverdrup, "Übersicht über das Klima des Polar. meeres und des Kanadischen Archipels, "Handbuch der Klimatologie, Band II, Teil K, Berlin, 1935, pp. 26-28. 


\section{TABLE 3}

B.EAN MONTHLY CLOUDINESS, CUMBILRLAND SOUND (0-10)

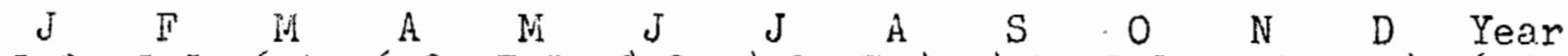
$\begin{array}{llllllllllllll}5.0 & 5.5 & 6.4 & 6.2 & 7.0 & 8.2 & 8.0 & 7.8 & 8.4 & 7.1 & 7.4 & 5.8 & 6.9\end{array}$

A thorough description of the climate requires a long record, and no such record is available. There are, however, four recent works dealing with the climate of the Canadian Arctic, and Cumberland Peninsula is included in these. $40,41,42,43$

The peninsula juts out into Davis Strait, and the distance from the north shore to the Cumberland Sound coast is only a little over one hundred miles. From the above tables it will be seen that the precipitation is relatively high for an arctic region, and the inean monthly temperatures, even at sea level and a long distance from the outer coast, are well above freezing for only two months of the year. The peninsula is mountainous, with tops up to seven thousand feet, and wide plateau surfaces only a few thousand feet lower. The precipitation falls as snow throughout most of the year in the higher parts, and although

40 H. G. Lorsey, Neteorological Characteristics of Northern Arctic America, thesis submitted for the degree of M.Sco, Massachusetts Institute of Technology, 1949, $71 \mathrm{pp}$.

$41 \mathrm{~F} . \mathrm{K}$. Hare, The Climate of the Eastern Canadian Arctic and Sub-Arctic and its Influence on lccessibility, thesis submitted for the degree of Ph.D, I Universite de Montreal, 1950, $440 \mathrm{pp}$.

42 W. C. Wonders, Climate of the Canadian Arctic Archipelago, thesis submitted for the degree of Ph.D., Toronto University, 1951。

4.3 R. W. Rae, Climate of the Canadian Arctic Archipelago. Toronto: Department of Transport, 1951, $30 \mathrm{pp}$. 
there are local continental regions with annual temperature amplitudes larger than the normal for the latitude, the climate on the whole is maritime in summer. The mean pressure distribution in sumner in the eastern Canadian Arctic has been described by Hare。 44 The lowest pressure lies over southern Baffin Island, and higher pressure over the Arctic Ocean; the abundance of Maritime Polar air along the Baffin Island coast is readily explainable, as the resultant flow over Davis Strait is from South and Southeast.

The height of the snow-line is mainly dependent on the climatic conditions in the area, but orographic factors are also important. It must be assumed that temperature conditions and precipitation do not vary to any considerable extent in the higher (accumulation) areas of the peninsula: the climatic conditions are favourable for continued glaciation in all the higher parts. The distribution of glaciers is to a large extent governed by the topography。 H. R. Thompson, who studied the geomorphology of the Pangnirtung Pass, has counted upwards of fifty glaciers on both sides, some of them pushing down valleys to the very bottom of the Pass, others filling hanging valleys and cirques.

It can also be assumed that the Penny Icecap is a survival from before the post-glacial climatic optimum; since the present day precipitation is too low for a reappearance of ice since that time. The same conclusion was reached in the more northern region

44 Hare, op. cit., pp. 47-48. 
of the Barnes Icecap, ${ }^{45}$ which was found to be in a fairly healthy state with an approximately balanced budget, only very recent slight receding, 46 and only a rather slight volumetric loss in 1949-1950.

The description of the variations of some of the Penny Icecap outlet glaciers in historical times will be dealt with by H. R. Thompson; from a preliminary examination it seems evident that the valley glaciers in the Pangnirtung Pass area are in a process of retreat, and thinning. 47

The easiest method of observing the variations of glaciers is to measure the marginal oscillations. These are a consequence of the thickening and thinning of glaciers and these latter changes in volume are far more difficult to determine. The glacier front reacts according to the size of the glacier, and is dependent also on the topography. ${ }^{48}$ Advances and retreats can therefore take place at different times, even in the same region. From a study of the outlet glaciers it is not possible to say with absolute certainly if the Penny Icecap proper has a negao

45 P. D. Baird, "Method of Nourishment of the Barnes Ice Cap," Journal of Glaciology, Vol. 2, No. 11, 1952, p.9.

$46 \mathrm{R}$. P. Goldthwait, "Development of End Moraines in EastCentral Baffin Island," Journal of Geology, Vol.59, No. 6, 1951, p. 569. 4. 1953 .

47 H. R. Thompson, "Geomorphology," Arctic, Vol. VI, No.

$48 \mathrm{H}$.W:son Ahlmann, "Glacier Variations and Climatic Fluctuations," Bowman Memorial Lectures, Series 3, Am。Geogr. Soc., New York, 1953, p. 8 . 
tive regime at the present time. The higher parts of the icecap still have a very short and interrupted ablation season, and although the firn line lies higher now than it did in the recent past, one would need to know if there has been an increase in winter accumulation before coming to a conclusion on the question of regime. Over a long period of time a surplus may be built up in the accumulation area, while the lower parts of the outlet glaciers waste away. A point may be reached when the ice again slides forward, more or less independent of the climatic conditions. Such a condition, according to Ahlmann, 49 is especially applicable to glaciers whose accumulation areas are situated on plateaus high above the valleys constituting their main ablation areas. Such are many of the Spitsbergen glaciers. The Penny Icecap closely resembles the icecaps of Spitsbergen. Further more, it has three outlet glaciers terminating in the waters of fiords; and most of the Spitsbergen glaciers terminate in floating tongues in fiords.

Some special types of polar icecaps have been described in recent years, in Peary Land 50 and Baffin Island. 51 The classification "Baffin Type" has been given by Baird to these icecaps, whose nourishment is not by accumulation of firn but

49 Ibid, p. 11

50 B. Fristrup, "Climate and Glaciology of Peary Land, North Greenland," Assemblee Generale de Bruxelles, $U_{0} G_{0} G_{0} I_{0}$ o 1951. Tome I, Louvain, 1952, pp.187-92.

5.1 P. D. Baird, "Method of Nourishment of the Barnes Ice Cap," Journal of Glaciology, Vol. 2, No. 11, 1952, p.9. 
by superimposed ice from the immediate refreezing of summer melt water. The Penny Icecap is different from its northern neighbour, the Barnes Icecap. It is not of the "Baffin Type", because it lies at a higher altitude and therefore reaches above the local firn line, about 5100 feet above sea level.

\section{OUTLINE OF THE THESIS}

The first step is to investigate how the meteorological conditions in the Cumberland Peninsula area during the summer of 1953 compare with the average conditions in that region. This comparison is undertaken in Chapter II. A comparison of the winter precipitation in 1952-1953 with the average for a long period is also carried out in that chapter, and as a result of these comparisons it is possible to state the degree of normality of the ablation conditions in the summer of 1953.

Chapter III deals with the meteorological observations on the icecap during the summer of 1953. The temperature grad ient over the snow surface is discussed, and the temperature conditions compared to those observed over a snow surface in Spitsbergen, east Greenland, and northern Baffin Island. A comparison of temperatures at Pangnirtung, Base Camp, and the icecap is also undertaken. The influence of the icecap on the climate of the nearby land is discussed with the help of observations made by other expedition members.

Humidity, wind and pressure conditions are then treated, and copies of weather maps for the stormy periods are presented, 
showing the possibility of cyclonic activity in Baffin Island. The observations of clouds, cloudiness, fog and precipitation are then treated. Chapter IV deals with the duration of sunshine and the radiation measurements.

Chapter $\mathrm{V}$ is devoted to the ablation conditions. The measurements were actually carried out by $W_{0}$. H. Ward and P。D. Baird with only occasional assistance from the author. Just enough is said about the ablation measurements to suffice in the present study, which mainly deals with the meteorological work done on the icecap.

Chapter VI deals with the heat exchange at the icecap surface。

Chapter VII is a study of the dependence of ablation on different meteorological factors.

In the final chapter (VIII) the results are re-stated and summarized to show the conclusions of the study. 


\section{CHAPTER II}

THE WEATHER IN THE CUMBERLAND PENINSULA DURING THE BUDGET YEAR 1952-1953

The closest permanent weather post to the icecap station was Padloping Island, on the north side of the Cumberland PenInsula, about eighty miles to the ENE, in position $67^{\circ} 06 \mathrm{~N}$, $62^{\circ} 21$ 'W. Surface data are avallable from this station from the sumner of 1941, and the following tables show mean values of temperature, precipitation, wind and cloudiness compared to the values for the summer months of $1953 .^{1}$

\section{SURFACE DATA FROM PADLOPING}

Air temperatures, degrees Fahrenheit.

TABLE 4

MEAN DAILY TEMPERATURE

Period: 1944-1953

lijean for period:

Niean for 1953:

\begin{tabular}{lccc} 
May & June & July & August \\
\hline 22.6 & 35.3 & 41.8 & 40.7 \\
27.6 & 33.9 & 41.8 & 40.1
\end{tabular}

TABLE 5

MEAN DAILY MAXIMUM TEMPERATURE

Period: 1944-1953

Mean for period:

\begin{tabular}{lccc} 
May & June & July & August \\
\hline 29.0 & 40.9 & 48.6 & 46.6 \\
32.9 & 38.8 & 48.6 & 44.5
\end{tabular}

Mean for 1953: 32.9

1 These data supplied by the Climatological Division, U. So Weather Bureau, Washington, D.C. 
TABLE 6

MEAN DAILY MINIMUM TEMPERATURE

Period: 1944-1953

Mean for period:

Mean for 1953:

\begin{tabular}{llll} 
May & June & July & August \\
\hline 16.2 & 29.6 & 34.9 & 34.7 \\
22.2 & 28.9 & 34.9 & 35.7
\end{tabular}

TABLE 7

ABSOLUTE MAXIMUM TEMPERATURE

Period: 1944-1953

Max。 in period:

Max。 in 1953:

\begin{tabular}{cccc} 
May & June & July & August \\
\hline 48 & 56 & 73 & 64 \\
45 & 47 & 73 & 59
\end{tabular}

TABLE 8

ABSOLUTE MINIMUM TEMPERATURE

Period: 1944-1953

Min. in period:

Min。 in 1953:

\begin{tabular}{cccc} 
May & June & July & August \\
\hline-14 & 20 & 25 & 20 \\
8 & 25 & 27 & 29
\end{tabular}

The absolute minimum temperatures in 1953 were higher, for each summer month, than the minima recorded during the nine previous years. The absolute maximum temperature in July set a ten-year record. The two months of June and August were, on the whole, slightly colder than the ten-year average; July was exactly normal. Only May was warmer than the average over the last ten years, although its absolute maximurn in 1953 was three degrees below the period absolute maximum of $48^{\circ}$. Reports from Pangnirtung in April indicated an early 
spring, 2 and this warm April weather lasted through most of May in the Cumberland Peninsula. After four days of low temperatures at the end of May, the temperature conditions became more seasonable, and remained very close to the ten-year averages.

Precipitation, inches of rain and snow. The total precipitation is the sum of rainfall and water equivalent of snowfall, calculated on the basis that ten inches of snow equals one inch of rain. T: trace.

\section{TABLE 9}

MEAN MONTHLY PRECIPITATION

\begin{tabular}{|c|c|c|c|c|}
\hline & Period & $\begin{array}{l}r \text { snon } \\
r \text { rair }\end{array}$ & $\begin{array}{l}1948-7 \\
1944-1\end{array}$ & \\
\hline & $\frac{\text { May }}{-}$ & $\frac{\text { June }}{0.22}$ & $\frac{\mathrm{July}}{0.58}$ & August \\
\hline Snow & $\overline{2}$ & 0.90 & 0.90 & 1.10 \\
\hline
\end{tabular}

Total for the four months: 1.88 inches.

TABLE 10

MONTHLY PRECIPITATION

Summer 1953

$\begin{array}{llllc} & \text { May } & \text { June } & \text { July } & \text { August } \\ \text { Rain }: & 0.01 & 0.40 & 1.03 & 0.72 \\ \text { Snow } & 2.30 & 0.80 & 2.40 & \mathrm{~T} \\ \text { Total } & 0.24 & 0.48 & 1.27 & 0.72\end{array}$

Total for the four months in 1953: 2.71 inches.

2 On April 26th the Hudson's Bay Company manager at Pangnirtung, $R_{0}$.J.Wickware, sent a radio message to the Arctic Institute suggesting that the Expedition arrive at Pangnirtung as early as possible, due to the spring season being advanced by four weeks over normal. Indications in the Pangnirtung area very definitely pointed to early spring. 
The four months May- August in 1953 thus had 0.83 inch more precipitation than the average over a longer period.

\section{Wind, direction and speed in m.p.h.}

TABLE 11

WIND, PERCENTAGE FREQUENCY BY DIRECTIONS

10-year period

North
Northeast :
East
Southeast
South
Southwest
West
Northwest :
Calm

\begin{tabular}{rrrrr} 
May & June & July & August & Mean \\
\hline 21 & 17 & 13 & 12 & $153 / 4$ \\
11 & 7 & 4 & 6 & 7 \\
10 & 10 & 12 & 13 & $11 \frac{1}{4}$ \\
5 & 7 & 11 & 10 & $8 \frac{1}{4}$ \\
7 & 7 & 9 & 9 & 8 \\
3 & 5 & 5 & 4 & $4 \frac{1}{4}$ \\
8 & 13 & 11 & 13 & $11 \frac{1}{4}$ \\
22 & 19 & 23 & 24 & 22 \\
13 & 15 & 12 & 9 & $12 \frac{1}{4}$
\end{tabular}

TABLE 12

WIND, PURCENTAGE FREQUENCY BY DIRECTIONS

Summer 1953

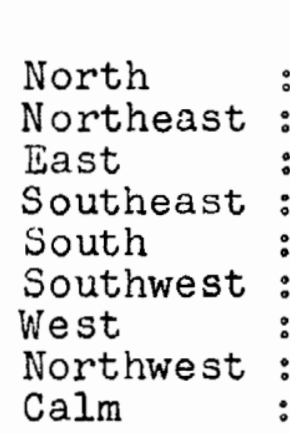

\begin{tabular}{rr} 
May & Jun \\
\hline 16 & 21 \\
18 & 12 \\
6 & 7 \\
5 & 4 \\
15 & 24 \\
11 & 3 \\
3 & 3 \\
13 & 16 \\
13 & 10
\end{tabular}

\begin{tabular}{rcl} 
July & August & Mean \\
\hline 24 & 21 & $20 \frac{1}{2}$ \\
5 & 10 & $11 \frac{2}{4}$ \\
4 & 3 & 5 \\
5 & 5 & $43^{3} / 4$ \\
29 & 10 & $19 \frac{1}{2}$ \\
3 & 3 & 5 \\
3 & 10 & $43 / 4$ \\
18 & 29 & 19 \\
9 & 9 & $10 \frac{3}{4}$
\end{tabular}

The months of May and August 1953 had the same percentage of calm weather as the average for those months over a tenmyear period. June and July had less calm weather than the average. The period as a whole had a little less calm weather than 
the average summer. The season had about average amounts of northerly and northwesterly winds; less easterly and westerly; but considerably more frequent southerly winds than the average. These prevailing southerly winds at padloping in 1953 were more frequent than normal in Nay, June and especially in July. As shown above, however, this does not seem to be of importance in the temperature conditions. Figures 7 and 8 show the per. centage frequency of wind by direction for the summer period.

\section{TABLE 13}

WIND, PERCENTAGE FREQUNNCY BY SPEIDS

$$
\text { 10-year period }
$$

\begin{tabular}{|c|c|c|c|c|}
\hline Speed in $m . p_{0} h$ & Way & June & July & August \\
\hline 32 and over: & 0.7 & 0.7 & 0.3 & \\
\hline $13-31$ & 24.1 & 18.6 & 16.3 & 16.7 \\
\hline $1-12:$ & 62.0 & 66.1 & $\begin{array}{l}71.4 \\
12.0\end{array}$ & 72.7 \\
\hline
\end{tabular}

TABLE 14

WIND, PIRCENTAGE FRE UENCY BY SPISDS

Surniner 1953

\begin{tabular}{|c|c|c|c|c|}
\hline Speed in $m . p_{0} . h$. & May & June & July & August \\
\hline 32 and over: & 2.8 & 0 & 0.4 & 0 \\
\hline $13=31:$ & 31.8 & 14.2 & 16.1 & 21.4 \\
\hline $1-12$ & 52.4 & 76.2 & 74.2 & 69.7 \\
\hline Calm & 13.0 & 9.6 & 9.3 & 8.9 \\
\hline
\end{tabular}

TABLE 15

WIND, PERCENTAGE FRI'UUEACY BY SHEDDS

FOR THE SUIMWIR PERIOD

Speed in m.p.h.

32 and over:

$13-31$ :

$1-12$ :

Calm 10-year period

0.8

18.9

68.0

12.3
Summer 1953 


\section{WINDROSES}
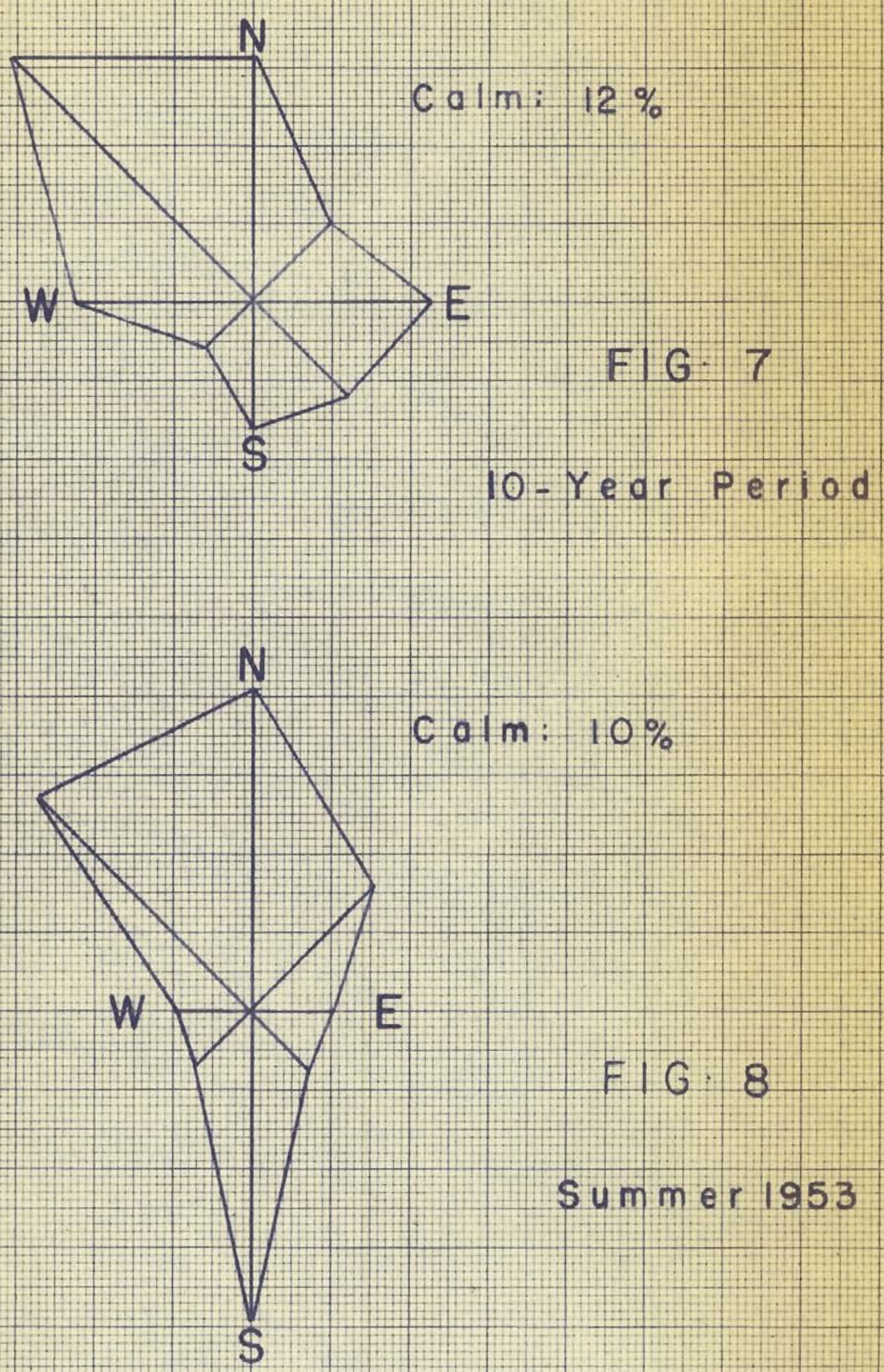
As noted above, the summer of 1953 had a little less calm weather than the average summer, but the wind conditions were very close to the average.

\section{Cloudiness, tenths of sky covered.}

TABLE 16

AVERAGE SKY COVER

Period: $1948-1953$

ivean for period:

\begin{tabular}{cccc} 
May & June & July & August \\
\hline 7.1 & 6.6 & 6.7 & 8.0 \\
6.9 & 7.5 & 7.8 & 7.8
\end{tabular}

May and August thus had a mean cloud cover only slightly below the average for the last six years; June and July rather more clouds than the average for the longer period. The dif ferences are not very large, however, and it must be remembered, as pointed out by Rae, ${ }^{3}$ that the observations of cloud amount are made non-instrumentally, and the accuracy is highly depen dent upon the experience of the observer.

II. SUMHARY OF WEATHER IN THE CUMBERLAND PENINSULA DURING THE SUMNER OF 1953

Padloping reports only surface weather observations and pilotaballoon observations of upper winds. There are no upper air data available in the Cumberland Peninsula. The nearest radiosonde stations to the icecap station are those at

3 R.W. Rae, Climate of the Canadian Arctic Archipelago. Toronto: Department of Transport, 1951, p. 21. 
Clyde (250 miles to the Northwest) and Frobisher Bay (230 miles to the Southwest). The nearest settlement in Greenland is 320 miles due East, at Holsteinsborg. The weather observations at Pangnirtung, on the south side of the Peninsula, were discontinued in 1942, after twelve years of records. It is therefore difficult to be specific in a comparison of the average weather in the Cumberland Peninsula with the summer conditions in 1953. The information obtained from the residents at Pangnirtung indicated an early spring. The month of May was, apart from the last four days, exceptionally fine and warm. However, June and early July proved to be somewhat colder and wetter than customary, and the break-up of ice in the Pangnirtung Fiord was about normal. The rest of the summer passed very much in the customary way.

The north side of the Peninsula, as shown by the data from Padloping Island, experienced a warmer May than the average; then the temperatures fell slightly below the average for June and again for August; July was very close to normal. In fact, the temperatures were, except for May, remarkably close to the average over a longer period, as the northern stations of Canada often have a greater average variability of temperaw ture from year to year than the southern stations. A list of ten stations at Hudson Bay-Hudson Strait and in Baffin Island show an average variation in mean daily temperature for July of 2.3 degrees $F .^{4}$

4 R. DeC.Ward, C. F. Brooks and A. J. Connor, "The Climates of North America," Handbuch der Klimatologie, Band II, Teil J. Berlin: Verlag von Gebruder Borntraeger, 1938, p. 374. 
The precipitation at Padloping was heavier than normal by 0.83 inches, but as a total for a period of four months this amount is not unusual. The greater amount of precipitation which falls on the southern part of Baffin Island is mainly due to the proximity of this region to the mean track of cyclonic storms from eastern Canada and the United States. In view of the fact that the precipitation in this part of the Arctic is of cyclonic origin to a large extent, the annual amount may vary considerably from year to year. ${ }^{5}$ The summer proved to be only very slightly wetter than the average over a longer period. At Padloping there were more southerly winds than the average, but less easterly and westerly winds. The wind speeds were quite close to normal summer conditions.

The cloudiness at Padloping was found to be greater than the average in June and especially in July, but this need not have been the case at the icecap station. An on-shore wind will usually bring a stratus deck over the coasts in the Arctic dur ing the summer, and for the smaller islands at least, a wind from almost any direction will bring in a deck of low cloud. 6 At the altitude of Camp Al it was frequently observed that the tops of the low clouds were below the station. It is probable that the cloud conditions were close to the average on the ice cap。
5 Rae, op.cit., p. 16.
6 Ibid., p. 24. 
From the available data it is safe to assume that the summer of 1953 was very close to the normal. The month of May was warmer and slightly drier than the average; but this is of little importance in our studies of the climate of the icecap. The temperatures at that altitude are, in May, so far below freezing that even a considerable increase would not influence the regime. The months of June, July and August had seasonable temperatures and precipitation, and on the icecap the summer s cloud conditions were probably also close to the average for a longer period.

The short, interrupted periods of melting on the icecap caused several ice layers to be formed on the surface, each layer in turn becoming snow covered. At the end of the ablation season the top layers, formed in 1953, were found to be very similar to those of previous years, now deeper in the firn.

The results of ablation measurements must always be seen in relation to the sumner weather. The conditions in 1953 were very close to an average ablation season.

\section{PRECIPITATION IN THE CUMBERLAND PENINSULA} DURING THE WINTER OF 1952-1953

When evaluating the regime of the icecap for 1952-1953 it is necessary to know the total accumulation. On a "Baffin Type" icecap this presents no problem, as the winter snow will be deposited on solid ice. Such was the case on the Barnes Icecap. ${ }^{7}$ The following table gives the total precipitation at

7 S. Orvig, "The Climate of the Ablation Period on the Barnes Ice-Cap in 1950," Geografiska Annaler, Vol. 33, Ht. 3-4, $1951, p .178$. 
Padloping for the average winter, and the precipitation for the winter 1952-1953.

\section{TABLE 17}

\section{MONTHLY PRECIPITATION, AUGUST-MAY}

Mean, six year period: August 1952-May 1953 :

Mean, six year period: August 1952-May 1953 :

$\begin{array}{cccccc}\mathrm{A} & \mathrm{S} & \mathrm{O} & \mathrm{N} & \mathrm{D} & \mathrm{J} \\ 0.55 & 1.46 & 1.41 & 0.46 & 0.37 & 0.46 \\ 0.20 & 1.39 & 2.61 & 0.42 & 1.65 & 1.03 \\ & & & \mathrm{~A} & & \mathrm{M} \\ & \mathrm{M} & 0.15 & 0.14 & 0.35 \\ & 0.35 & 0.27 & 0.24\end{array}$

At Padloping the precipitation from August 1952 to May 1953 amounted to 9.46 inches, while the normal for the same period is 5.60 inches. The normals for Padloping are only for a six year period and are probably different from long-term means. It is known that the annual amounts of precipitation may vary considerably from year to year in the eastern Arctic. Pangnirtung, on the south side of the Cumberland Peninsula, recorded a precipitation of 18.16 inches from August 1939 to ivay 1940, but only about six inches from August 1940 to May 1941. It is reasonable to suppose that the accumulation on the Penny Icecap in the budget year 1952 - 1953 was close to the average. This fact, combined with the normal conditions during the ablation season, must have resulted in a typical budget year. The results of the investigations on the Penny Icecap in 1953 can therefore be taken as a true picture of the average conditions. 
METEOROLOGICAL OBSERVATIONS ON THE PENHY ICECAP

\section{TEMPERATURE}

The temperature is the most important meteorological element in the study of ablation, for it is a function of all the different meteorological factors, such as insolation, wind and humidity, which influence the ablation. It is necessary, in the study of the correlation between temperature and ablation, to have temperature recordings taken on the glacier itself, not only at a constant level, but also at several points in the layer some meters above the surface.

The temperature was observed every two hours from 0800 to 2000 daily by a screened thermometer and an Assmann psychrometer at three feet, and by means of thermistors at thirteen and twenty-three feet above the surface. Continuous thermograph recordings were taken for the whole period, and the trace is only interrupted on May $28 \mathrm{th}$ and $29 \mathrm{th}$, when the pen dropped below the zero degree $(F)$ base line. The two-hourly readings at three levels are complete for the period May 2lst to August 9th, with the exception of the three foot readings on May 28th, 29 th and June 13th, when the weather prohibited all activity. Controls of the thermograph were made three times daily by the dry bulb thermometer. The temperature varied very slowly, the greatest change being experienced on July I6th, when the temperature dropped eight degrees in less than two hours. This 
took place between 2 and 4 a.m., after a day with very wet fog and rain and a diurnal variation of temperature of only 3.5 degrees. The wind veered from $\mathrm{SW}$ to $\mathrm{NE}$ during the night, and the temperature immediately dropped. The mean temperature on the 15 th was $33.1^{\circ}$, on the following day only $13.1^{\circ}$. Variations of five to seven degrees within a minute, as reported by Eriksson from the Frbya Glacier in northeast Greenland, ${ }^{1}$ were never experienced on the two icecaps in Baffin Island. Mean temperatures for different periods, at three feet above the surface, are presented in the following table.

\section{TABLE 18}

\section{NEAN TEMPERATURES}

May (11 days): 11.3 June: 14.8 July: 25.8 August (9 days):256 Period May 21 - July 12 (negligible ablation): 16.2 Period July 13 - August 9 (interrupted period of ablation): 26.4 Wean daily temperature for period of investigation: 19.7

The mean temperature for each day of investigation is given in Table I. The warmest days were July 24 th and 25 th with a mean temperature of 35.6 ; the coldest day was May 28 th with a mean temperature of -9.4 .

Five-day running means of mean daily temperature are given in Table II. Figure 9 shows mean temperature for each day, and five-day running means of mean daily temperature. tion on the Froya Glacier in Relation to Radiation and Meteorow logical Conditions," Geografiska Annaler, Vol. 24, 1942, p. 23. 


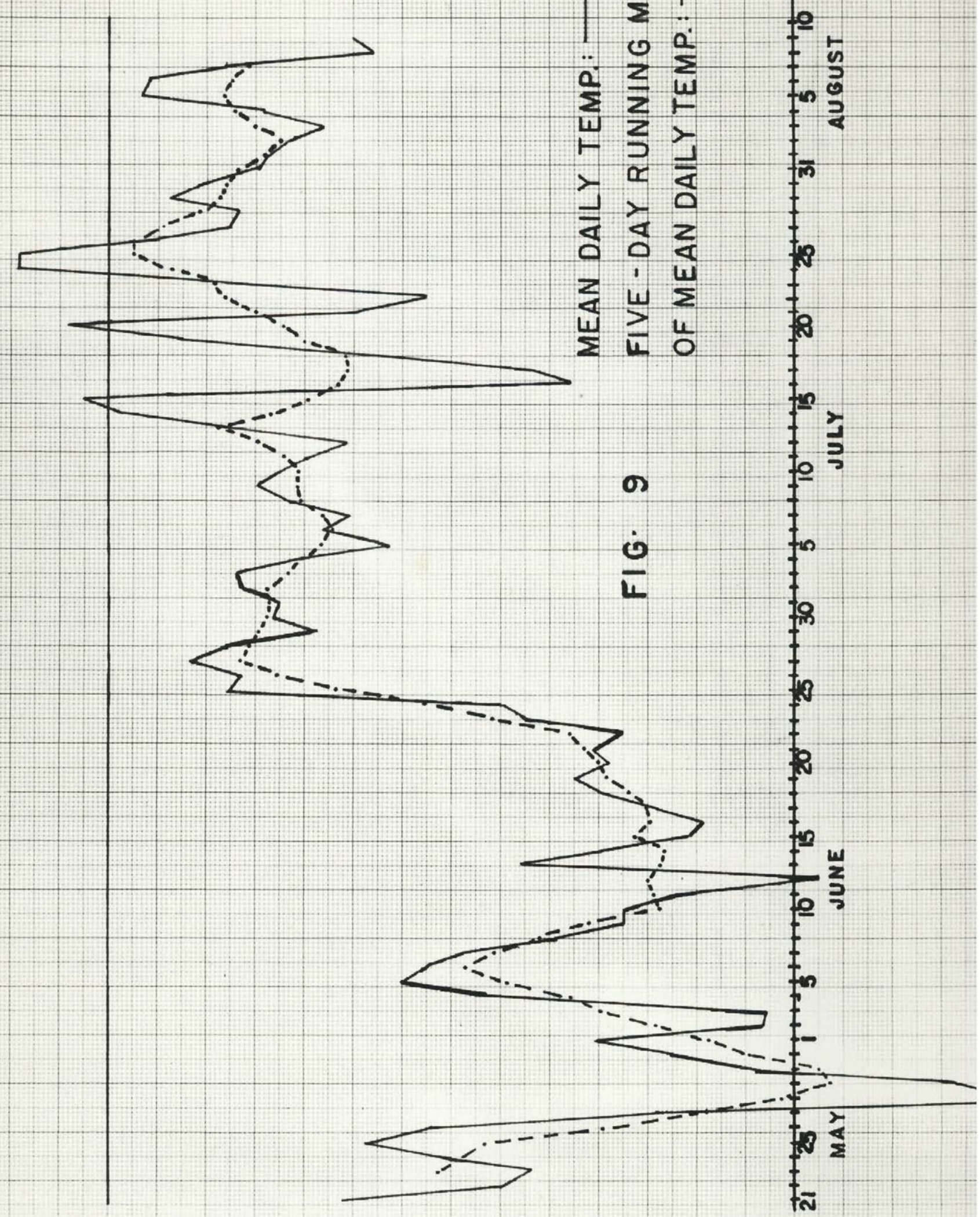

票出 
Daily maximum and daily minimum temperatures are given in Table III. The absolute maximum was 38.5 on July 25 th, and the absolute minimum was -13.5 on May 29th. The daily maximum was not usually recorded at a certain time of day; on the average the daily maximum fell between noon and 1600, while the daily minimum most frequently was recorded between midnight and 0400. The extreme maximum occurred at 1500, during a short, clear period on a caln, foggy day. The minimum was recorded around midnight, during a period of blizzard. Figure 10 shows the daily maximum and minimum temperature.

\section{TABLE 19}

MEAN DAILY MAXIMUM AND MINIMUM TEMPERATURE

liean daily max.:

Mean daily min.:

\begin{tabular}{cccc} 
Niay (11 days) & June & July & August $(9$ days) \\
\hline 18.5 & 18.5 & 29.8 & 29.5 \\
8.2 & 11.1 & 21.7 & 21.7
\end{tabular}

The daily range of temperature is given in Table IV. The greatest daily range of temperature was 22.1 degrees and occurred on May 29 th. The least daily range was 1.7 degrees on June 30th. May 29 th had severe blizzard conditions, and the great daily range was caused by the record low minimum: -13.5 . June 30 th had very thick fog, some snow and heavy hoar-frost. The mean daily range of temperature was greatest in May, 10.3 degrees, and the least in June, 7.4 degrees. For July it was 8.0 and for August 7.9 degrees. The observations on the Barnes Icecap in 1950 showed that during the period of continuous surface melting in July, the surface had a definite 


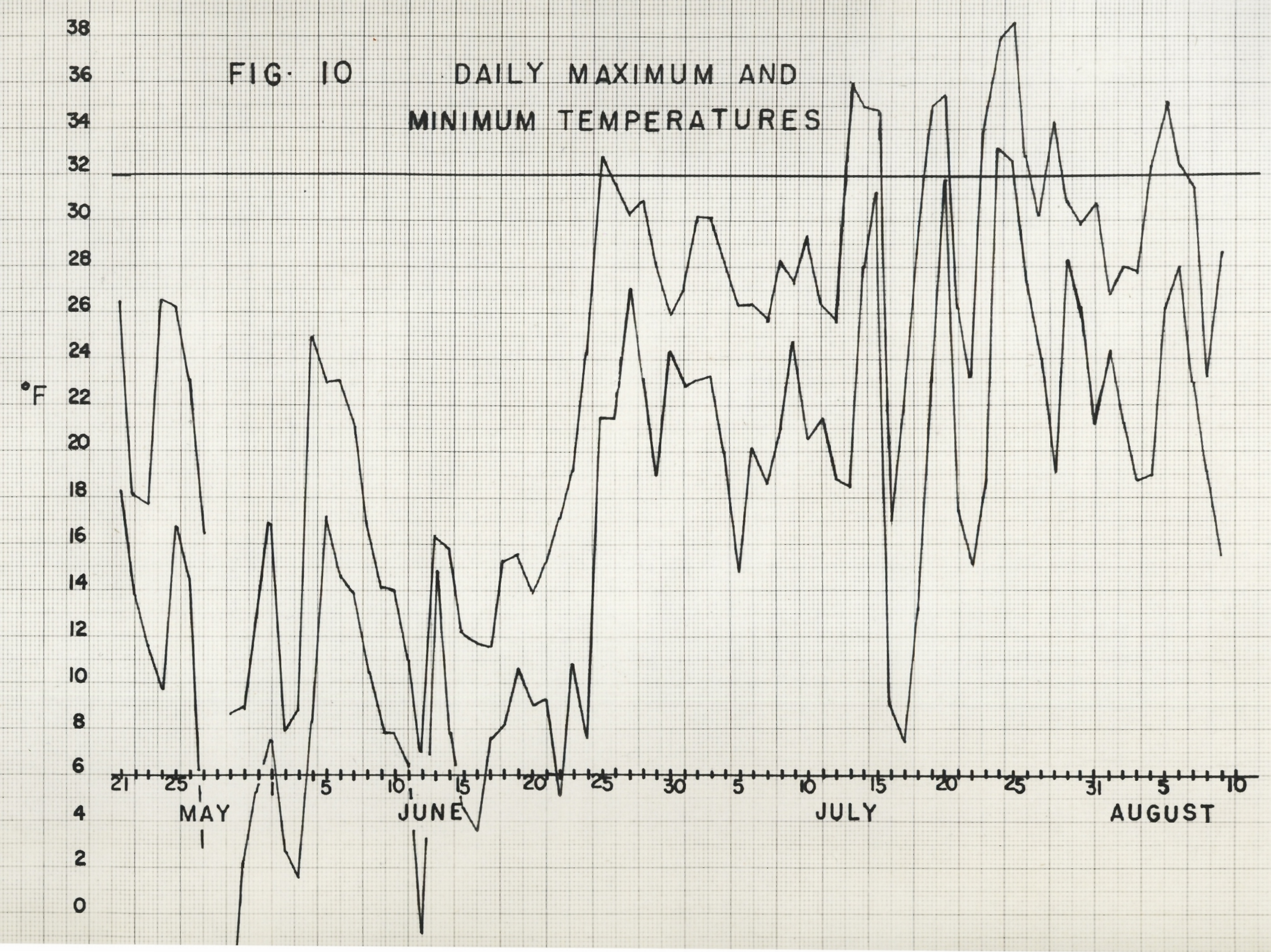


stabilizing effect on the air temperature. July had the least mean daily range, 5.6 degrees, and the longest period of surface melting. ${ }^{2}$ on the Penny Icecap the melting was of much shorter duration, interrupted by periods of colder weather, but there is evidence of a stabilizing effect by the surface during the short melting periods. On the whole, however, the daily range of temperature at Camp Al was dependent on cloud conditions and wind direction more than on the surface snow conditions. A melt of sixty hours' duration commenced on July 13th, when the temperature climbed to $36.1^{\circ}$; one of thirty hours on July 19th, which had a maximum of $35.0^{\circ}$; and one of sixty hours on the evening of July $23 \mathrm{rd}$. The thermograph traces for these periods and the colder periods between are reproduced in Figure 11, and a slight tendency to a stabilizing effect by the melting snow surface is noticeable in the three warmer periods.

\section{A comparison of temperatures at Padloping, at Base Camp} and on the icecap. The following tables present a picture of the differencesin temperatures at three locations: Padloping on the coast, Base Camp at Sumnit Lake in Pangnirtung Pass (1300 feet above sea level, 24 miles from Pangnirtung Fiord and 28 miles from North Pangnirtung F'iord), and the icecap station at 6725 feet.

2 S. Orvig, "The Climate of the Ablation Period on the Barnes Ice-Cap in 1950," Geografiska Annaler, Vol. 33, Ht. 3-4, 1951, p. 182: 

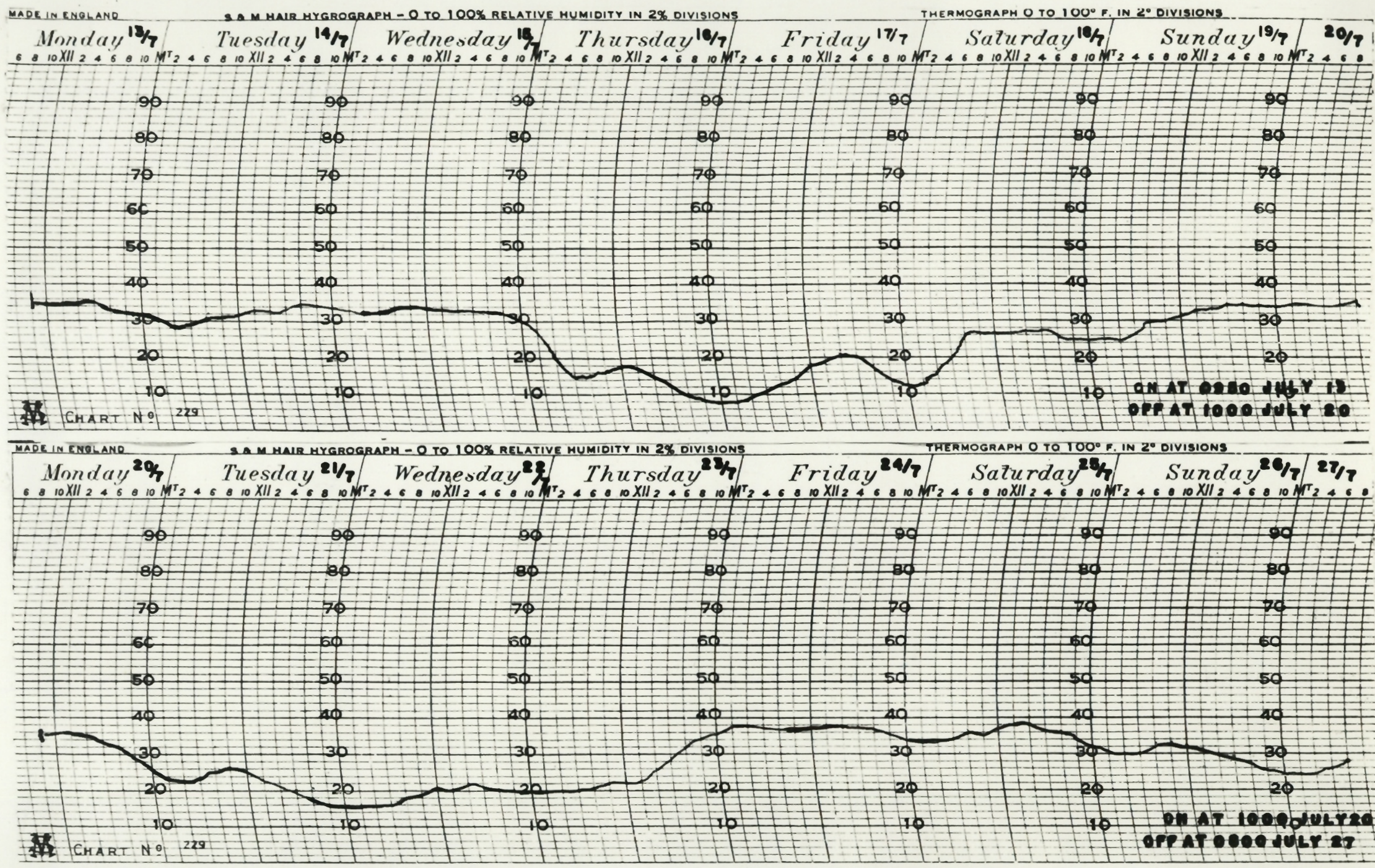

\section{FIG. II THERMOGRAPH TRACES}


Padloping:

Base Camp:

Icecap :

Padloping:

Base Camp:

I cecap

\begin{tabular}{cccc}
0800 & 2000 & Mean Maximum & Mean Minimum \\
\hline- & - & 38.8 & 28.9 \\
33.8 & 32.8 & 38.5 & 28.3 \\
16.2 & 14.6 & 18.5 & 11.1
\end{tabular}

TABLE 21

MEAN TEMPERATURES, JULY

\begin{tabular}{cccc}
0800 & 2000 & Hean Maximum & Mean Minimum \\
\hline 41.6 & 40.9 & 48.6 & 34.9 \\
27.3 & 26.8 & 47.6 & 34.4 \\
& & 23.8 & 21.7
\end{tabular}

TABLE 22

MEAN DAILY TEMPERATURES

$\begin{array}{lllll} & \text { May } & \text { June } & \text { July } & \text { August } \\ \text { Padloping: } & 27.6 & 33.9 & 41.8 & 40.1 \\ \text { Base Camp: } & 29.8 \text { ( } 8 \text { days) } & 33.4 & 41.0 & 41.2 \\ \text { Icecap } & 11.3 \text { (Il days) } & 14.8 & 25.8 & .25 .6 \text { (9 days) }\end{array}$

Figures 12 and 13 show the mean temperature at 0800 and 2000 and the mean maximum and minimum temperature at Base Camp and Camp Al for the months of June and July. The maximum temperature is plotted at 1400, although the time of occurrence of maximum temperature varied, and the minimum temperature is plotted at 0400 . Both these times are reasonably close to the average time of occurrence. The mean temperatures at 0800 and 2000 for Padloping are not available, but the mean maximum and mean minimum temperature both for June and July are very close to those recorded at Base Camp, all values at Padloping being higher by one degree or less. The temperature curve for Padloping would therefore most likely run very close to that for 


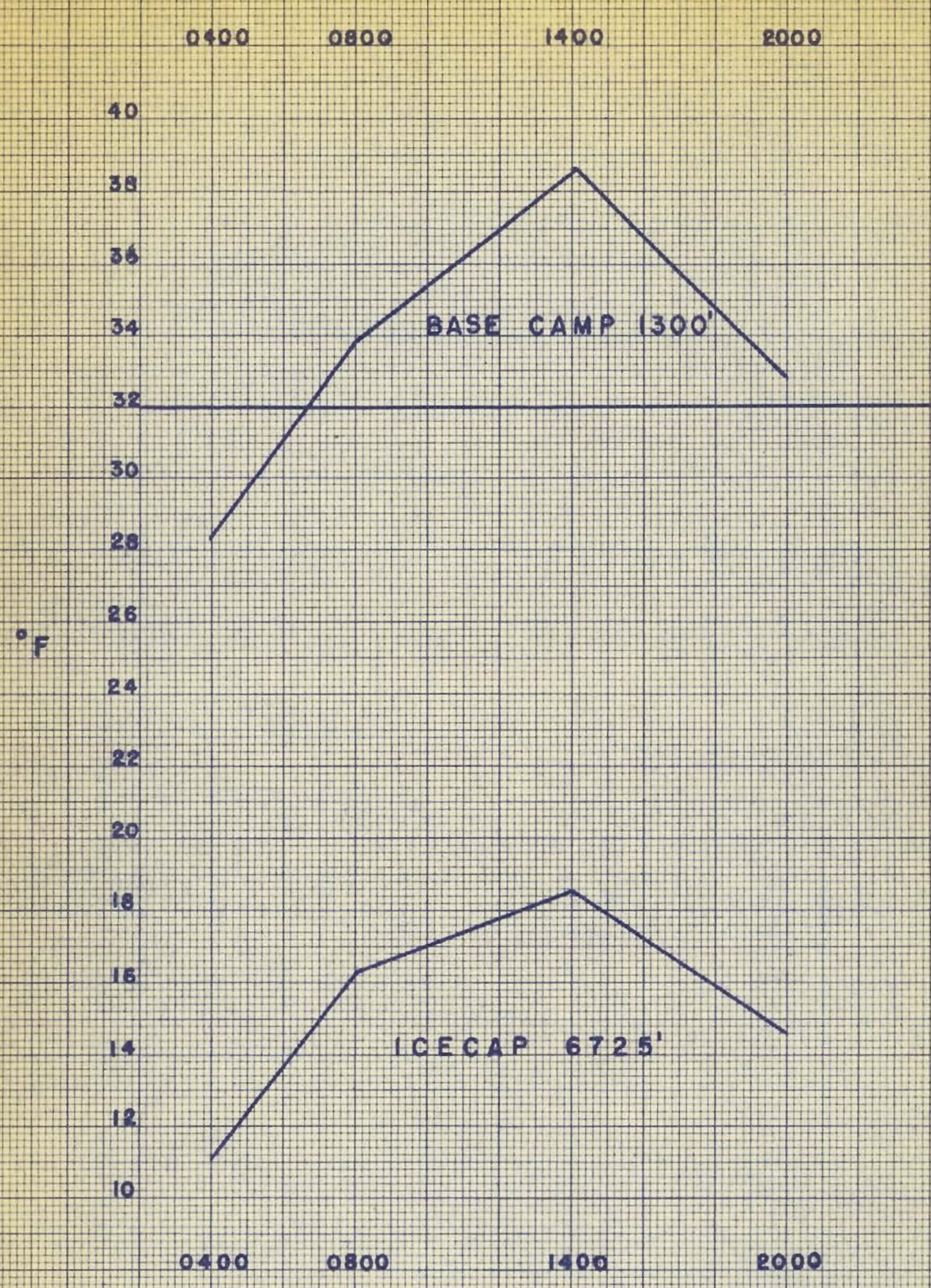

FIG: 12 MEAN TEMPERATURES JUNE 


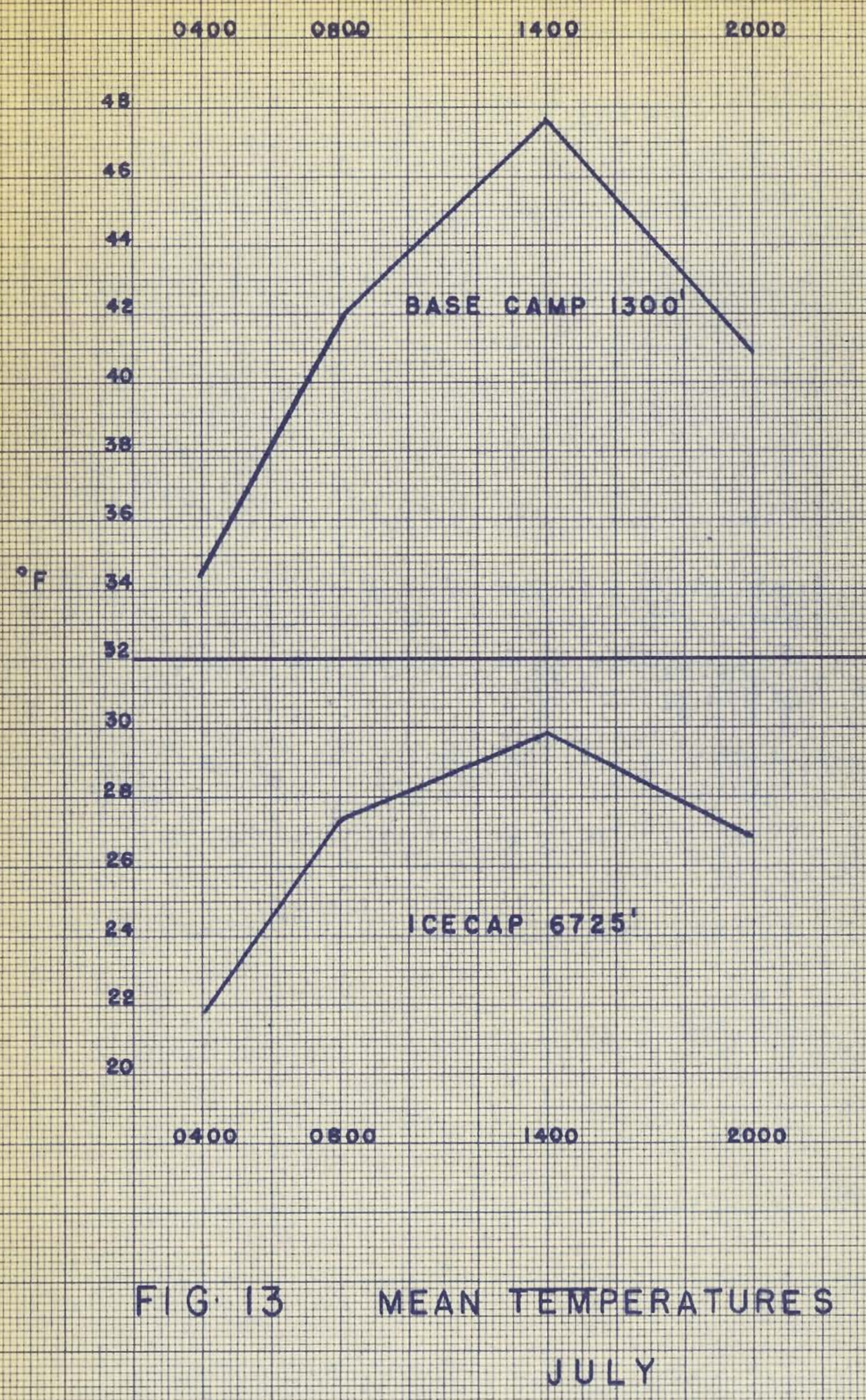


Base Camp.

Figure 14 shows the mean daily temperatures at the three stations for each of the four months May - August. It must be borne in mind that the periods of observation in May and August are of different duration for the three stations. The May observations on the icecap include the last eleven days of the month, and the probably lower temperatures earlier in the month are not considered: similarly for the temperatures after the gth of August. The drop from July to August was actually steeper than that indicated. The Base Camp temperature observations include only the last eight days of Nay, and in reality the padloping curve should probably not drop below that of Base Camp. The same is the case for August. The Padloping value is the mean of 31 days, the Base Camp value is the mean of 26 days. The difference in temperature between Padloping and Base Camp is very small, the inland location of Base Camp being counteracted by the higher altitude. In this connection reference should be made to the differences found in 1950 between the temperature on the maritime coastal zone at Clyde, and the more continental zone at sea level at the head of clyde Inlet, seventy miles inland, where mean daily maximum for June was 5.6 de

The mean daily temperature increased from Nay to June at a very similar rate for all three stations. Considering the shorter observation periods at Base Camp and AI the increase

3 Orvig, loc. cit. 


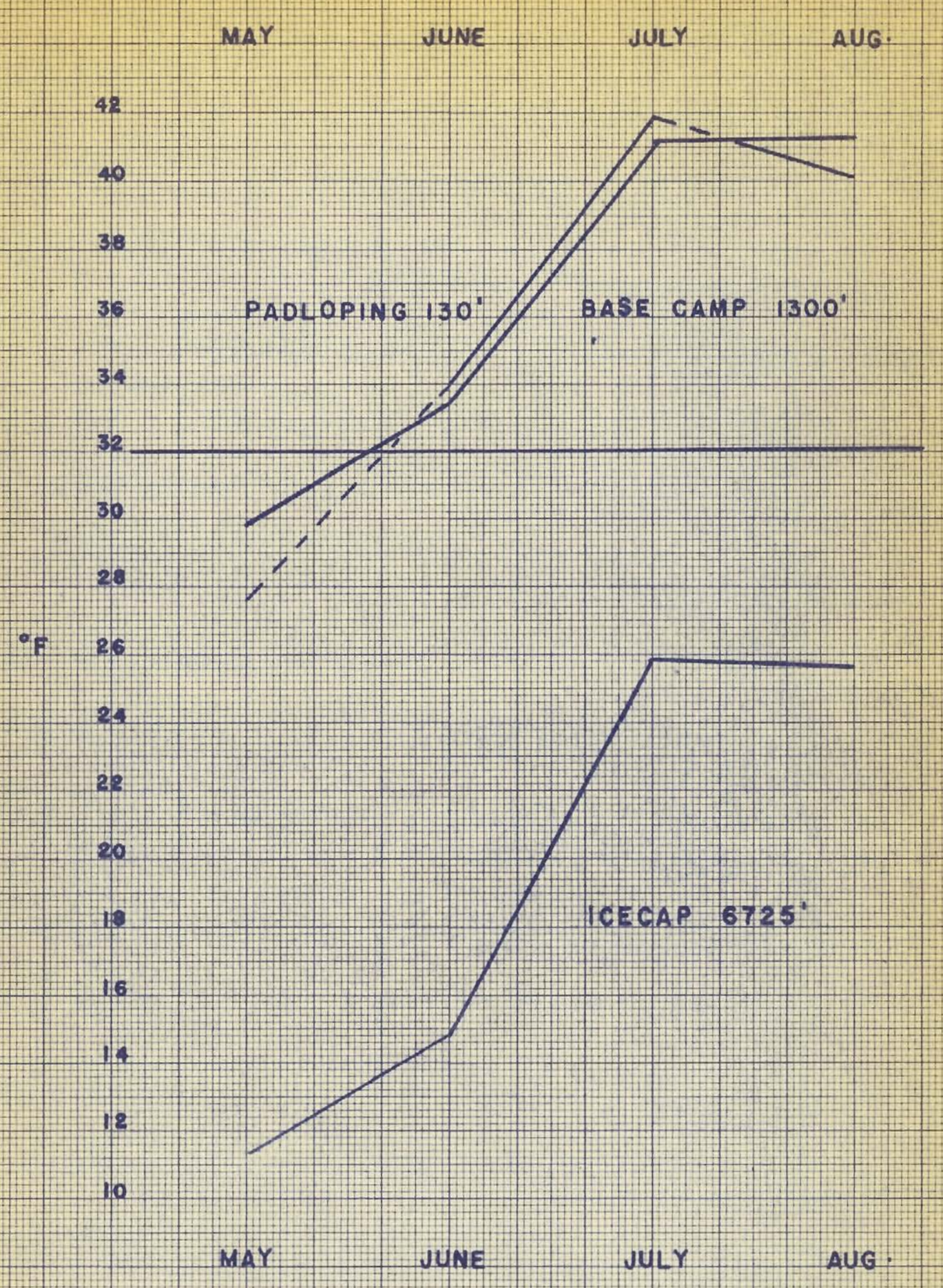

FIG: I4 MEAN DAILY TEMPERATURES 
was probably similar to that at Padloping, where it amounted to 6.3 degrees. This was before melting of snow and ice had commenced. From June to July the increase in mean daily temperature was 7.9 degrees for Padloping, 7.6 degrees for Base Camp and 11 degrees on the icecap. From July to August (again considering the different lengths of observation periods) the mean daily temperature decreased by 1.7 degrees at Padloping, increased by 0.2 degrees at Base Camp ( 26 days of observation) and must have decreased by consideraly more than 0.2 degrees on the icecap. July was thus the warmest month at Padloping and on the icecap, and probably also at Base Camp, as the temperatures there, on the last five days of August, may well have been low enough to give a mean temperature for August of less than $41^{\circ}$.

The average difference in temperature between Base Camp and the icecap station is calculated in the following table, using the mean of the temperatures measured every day at 0800 , 1400 and 2000 , for similar periods at the two locations.

\section{TABLE 23}

DIFFERENCE IN MEAN TEMPERATURES AT BASE CAMP AND AI

\begin{tabular}{llcccccccc} 
& \multicolumn{3}{c}{ June } & \multicolumn{3}{c}{ July } & \multicolumn{2}{c}{ August (9 days) } \\
& 0800 & 1400 & 2000 & 0800 & 1400 & 2000 & 0800 & 1400 & 2000 \\
Base Camp: & 33.8 & 38.0 & 32.8 & 41.6 & 46.0 & 40.9 & 40.7 & 48.9 & 41.3 \\
Icecap : & 16.2 & 16.6 & 14.6 & 27.3 & 28.0 & 26.8 & 27.2 & 27.9 & 26.8 \\
Difference: & 17.6 & 21.4 & 18.2 & 14.3 & 18.0 & 14.1 & 13.5 & 21.0 & 14.5
\end{tabular}

The average difference was 17 degrees. The altitude of Base Camp was 1300 feet, that of Al 6725 feet. The average difference was thus 0.31 degrees $F / 100$ feet, or 0.56 degrees 
C/100 meters; this is practically the same as the mean lapse rate of the free atmosphere and is to be expected, as the air moving across the icecap from any direction passes over land which is partly snow and ice covered, and the air is not subject to much warming from the ground. Reference should here be made to a similar calculation of temperature differences between Clyde (on the coast) and the icecap station on the Barnes Icecap. A temperature gradient of 0.6 degrees $C / 100$ meters was found in this locality, ${ }^{4}$ indicating a uniform value over large areas in Baffin Island.

Temperature conditions at three levels above the surface at station Al. The vertical variations of temperature above the glacier surface must be ascertained in order to study the heat balance at the surface. This is of fundamental importance in the ablation process. The temperature observations were undertaken at three levels: three, thirteen and twenty-three feet above the surface. Thermistors were placed at these heights on an aluminium mast, and the three foot readings from the thermistor were compared with the simultaneous readings from the Assmann dry bulb thermometer. A small correction was usually necessary and this correction was then applied to the thermistor readings at thirteen and twenty-three feet. The thermistors were calibrated, but at times a combination of strong radiation and calm weather caused a slightly higher reading than that recorded by the ventilated dry bulb thermometer. 
W. H. Ward again calibrated the thermistors on his return to England, and the readings are of a degree of accuracy comparable to the thermometer readings.

Figure 15 shows the two higher thermistors on the aluminium mast. The leads were extended into the living tent, where the temperatures were calculated by Wheatstone bridge and tables. Figure 16 shows the thermistor at three feet above the surface. Table $\mathrm{V}$ gives the daily means of seven temperature observations, carried out every second hour from 0800 to 2000 daily, for the three levels above the surface.

On the Barnes Icecap, in 1950, it was found that, except for a very few cases, the temperature increased with height above the surface of the snow. 5 The same was not the case on the Penny Icecap, as can be seen from Figure 17, in which the temperatures given in Table $\mathrm{V}$ are set forth graphically. Abovefreezing daytime temperatures were recorded at all three levels on July 13th, 14th and 15th, on July 19th and 20th, on July 24 th and 25 th, and at twenty-three feet on July 28th. In August only the 5th had above-freezing daytime temperature.

Thirteen days of a total of seventy-five days with complete records show a temperature distribution like that found to be most frequent on the Barnes Icecap: increasing with height above the surface. Five of the eight days with above-freezing temperatures at all three levels had this temperature distribution, indicating a loss of heat to the melting snow surface. Twenty-nine days of the total seventy-five show decreasing tem- 
$-59-$

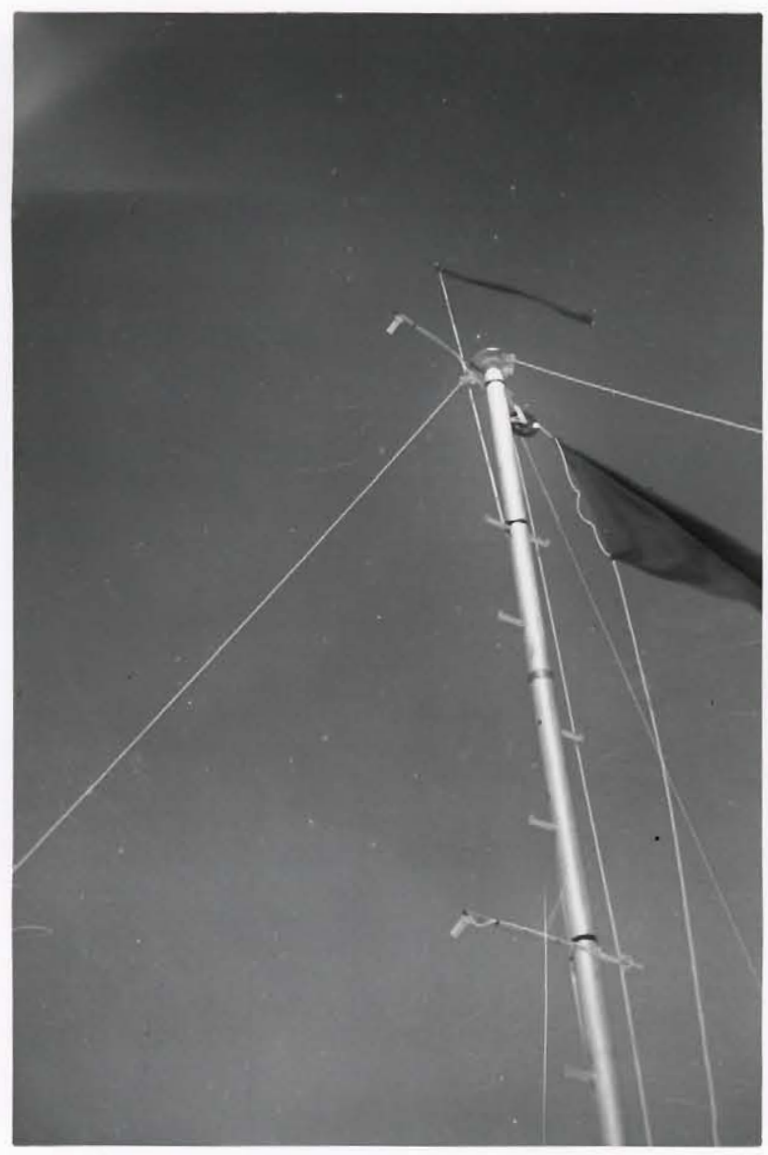

Fig. 15. Thermistors on Mast. 


$$
-60-
$$

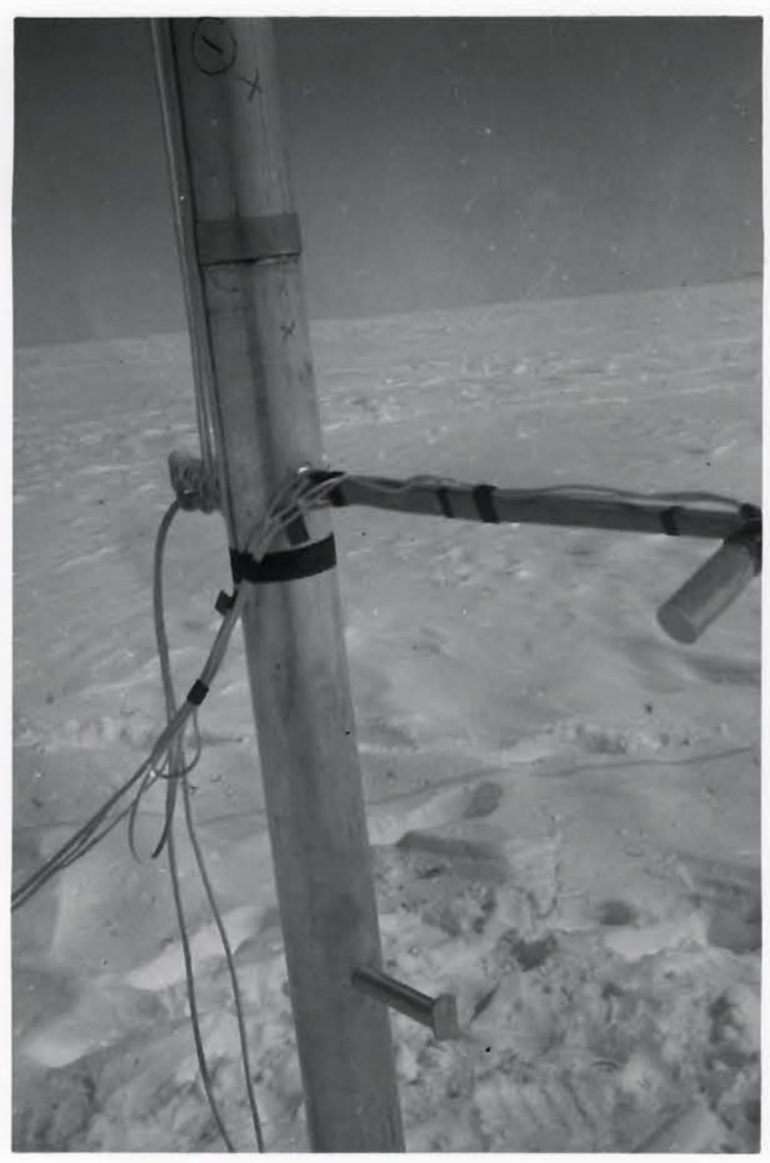

Pig. 16. The Thermistor at Three Feet. 


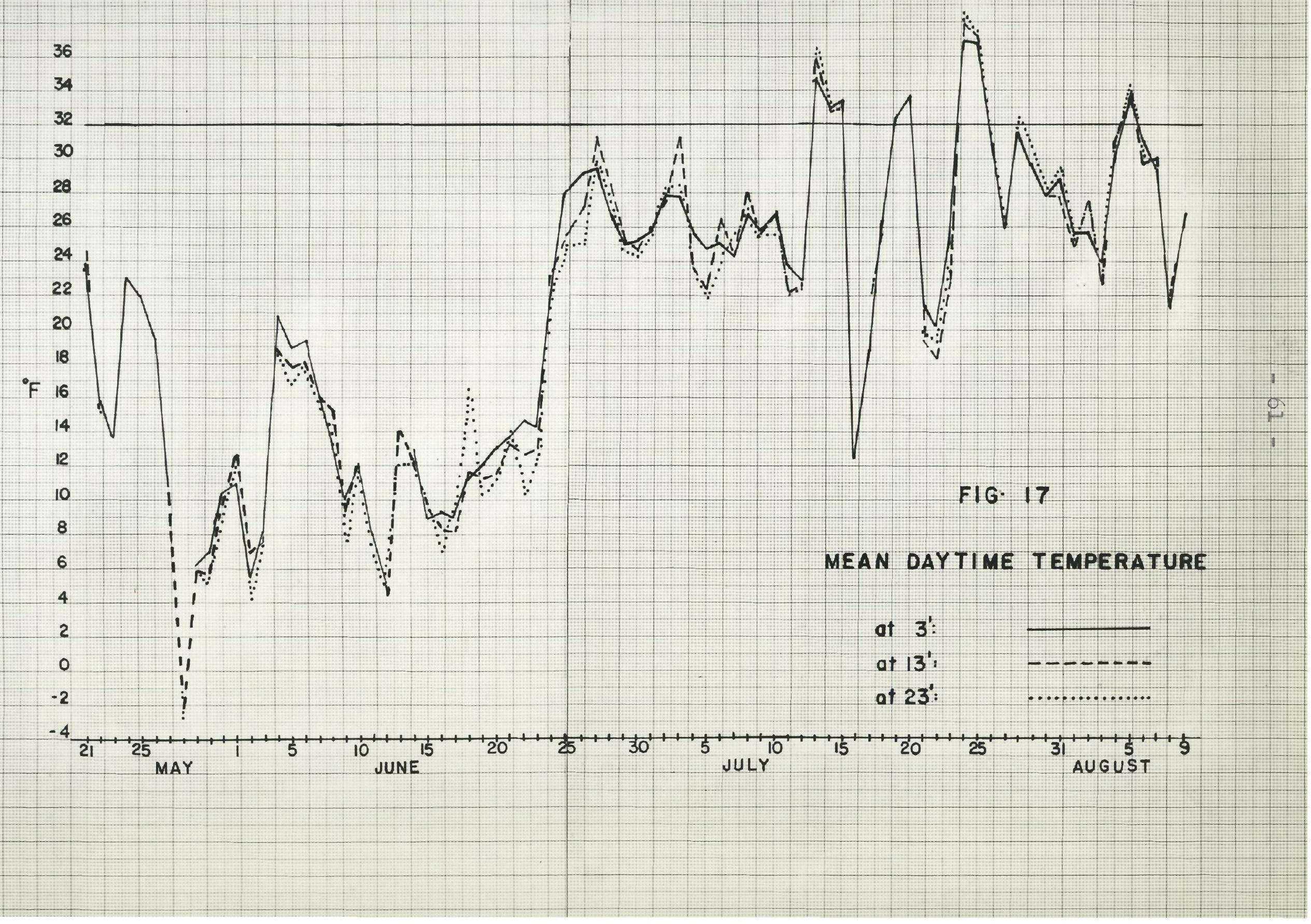


perature with height. Eighteen days show increasing temperature up to thirteen feet, then decreasing to twenty-three feet. Fifteen days show decreasing temperature up to thirteen feet, then increasing to twenty-three feet. Nine days had the same temperature reading at thirteen and twenty-three feet; in three cases this reading was higher than the three foot reading, in six cases it was lower.

On the Barnes Icecap 78 per cent of the time had a "normal" gradient of increasing temperature with height. Increasing temperature to thirteen feet, and then decreasing, was experienced 20 per cent of the time, and the lowest at thirteen feet only 2 per cent of the time.

On the Penny Icecap this "normal" gradient of increasing temperature with height was only measured 17 per cent of the time. Increasing temperature up to thirteen feet, and then decreasing, was recorded for 24 per cent of the time. Decreasing temperature to thirteen feet and then increasing, was recorded for 20 per cent of the time. A straight drop in temperature with height was recorded for 39 per cent of the time. A comparison of the two icecaps is given in the following table.

TABLE 24

TLMPERATURE GRADIENTS OVER THE SURFACE

$$
\text { per cent of time }
$$

$\begin{array}{ccccc} & \begin{array}{c}\text { Increasing } \\ \text { with height }\end{array} & \begin{array}{c}\text { Increasing } \\ \text { then decreasing then increas. }\end{array} & \begin{array}{c}\text { Decreasing } \\ \text { thith height }\end{array} \\ \text { Barnes Icecap: } & 78 & 20 & 2 & 0 \\ \text { Penny Icecap: } & 17 & 24 & 20 & 39\end{array}$


This table shows that the temperature distribution above the surface on the Barnes Icecap was, in most cases, a very stable one. Wallen found the same on the Karsa Glacier in northern Sweden. There an unstable lapse rate was only experienced in spring, and then almost exclusively when the temperature was below freezing. 6

The conditions on the Penny Icecap were found to be far more unstable. The stability conditions are complicated, but the more frequent unstable lapse rates were experienced in May and early June. In this period no cases of straight increase with height were found. The stable conditions found on the Barnes Icecap indicate that heat must have been transported from the air to the icecap surface during most of the ablation season. The air temperatures were above freezing for a long period, partly due to the relatively low altitude. In the cases of below-freezing air temperatures the surface sometimes (because of radiation conditions) was at melting temperature and a more unstable distribution could be found in the lower layers. On the Barnes Icecap the average lapse rate was $+13.1^{\circ} \mathrm{F} / 100$ feet $=+24^{\circ} \mathrm{J} / 100$ meters between three and twenty-three feet; on the days with increasing temperatures up to thirteen feet the average lapse rate was $-4.6^{\circ} \mathrm{F} / 100$ feet $=-8^{\circ} \mathrm{C} / 100$ meters between thirteen and twenty-three feet. On the Penny Icecap the mean temperatures at the different levels were as shown in the following table.

6C.C. Wallen, "Glacial-Meteorological Investigations on the Karsa Glacier in Swedish Lappland 1942-1948," Geografiska Annaler, Vol. 30, Ht. 3-4, 1948, p. 514. 
TABLE 25

MEAN TEMPERATURES AT THREE LEVELS

Increasing with height

Increasing, then decreasing:

Decreasing, then increasing:

Decreasing with height

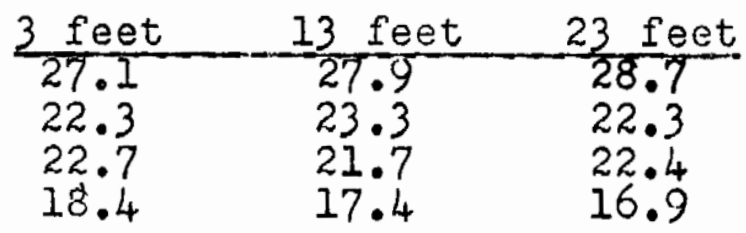

It is seen that the coldest period had the most unstable conditions, which corresponds to Vallen's results as mentioned above. The 17 per cent of the observations which showed very stable conditions fell, on the whole, on the warmest days. It must be borne in mind that these observations are of daytime temperatures only, but they give a good picture of the actual conditions because the daily variation of temperature was small. In a very detailed study of the temperature distribution at different levels one would have to use potential temperature instead of the actual temperature. The amounts to add to the actual temperatures to obtain the potential temperatures at three, thirteen and twenty-three feet are respectively: 0.016, 0.07 and 0.12 degrees $F$. These amounts are of the same order of magnitude as the observational errors in the temperature re cordings, and actual temperatures have been used throughout this chapter.

The lapse rates for the different degrees of stability are shown in the following table. 
- 68 -

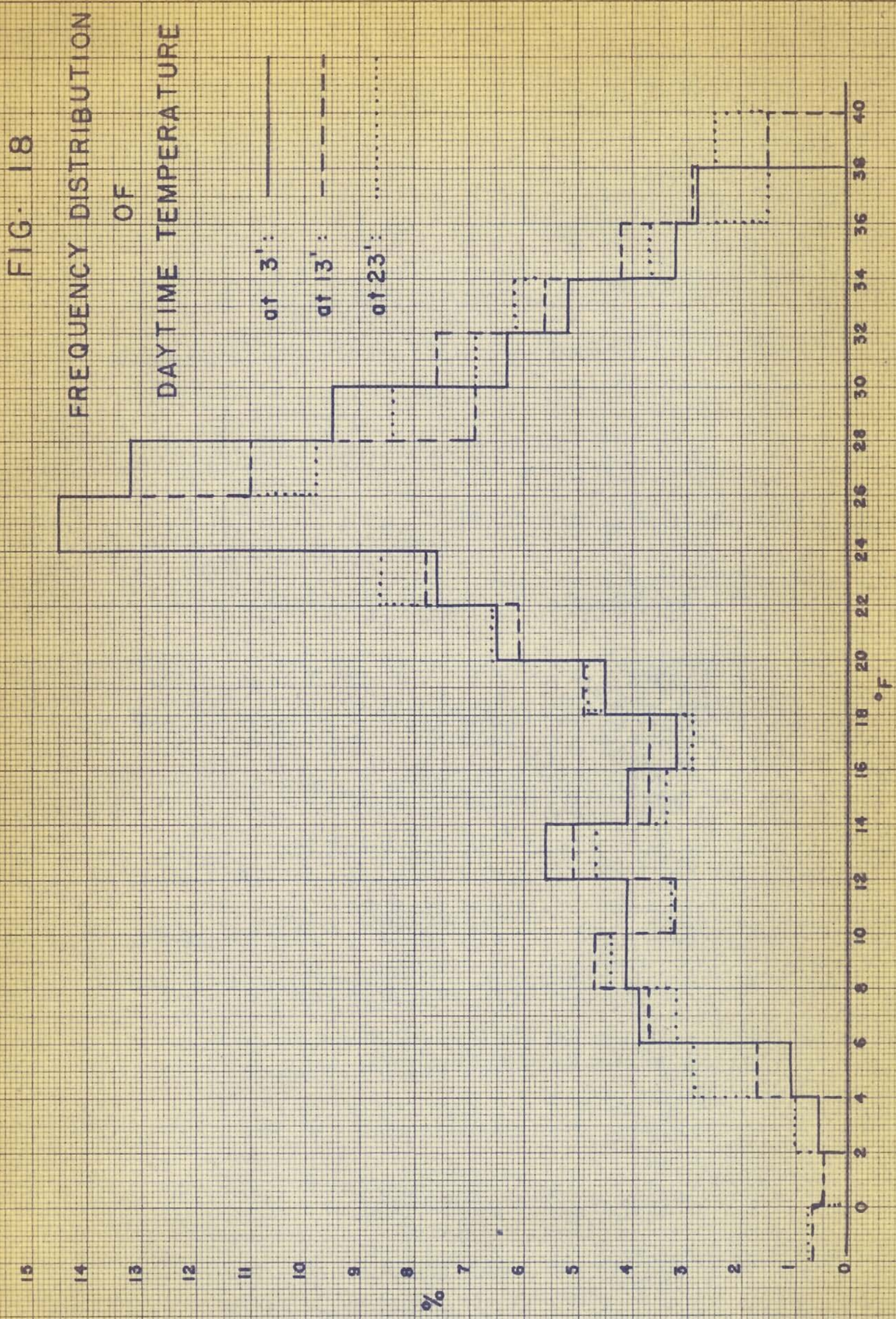


that the icecap acts as a temperature stabilizer. It endeavours to lower the air temperature to $32^{\circ}$, its own temperature in the ablation season. The investigations by Eriksson of the Froya Glacier records gave the results that a maximum frequency was found in the interval $40.1^{\circ}-41.9^{\circ}$ at $4.8^{\circ}$ feet above the surface, and no negative temperatures. ${ }^{15}$ At only 3.2 inches above the surface the temperature was usually as high as $35.6^{\circ}$. On Clavering Island, therefore, the glacier is incapable of reducing the air temperature to freezing. On the other hand, Sverdrup found on Isachsen's Plateau 16 that the maximum frequency occurred in the interval $32.9^{\circ}-34.3^{\circ}$, or the same as found on the Barnes Icecap. Furthermore, both the curves for 16.4 feet and 1.6 inches above the snow surface on Isachsen's Plateau include below-freezing temperatures, and the effect of the cold surface is present even at 16.4 feet, where there is a marked drop in the frequency curve at $36^{\circ}$. The frequency curves for the Barnes Icecap showed exactly the same characteristics, only the curve for the highest level showing a tendency to approach a symmetric form, as the cooling effect of the melting snow surface grew less.

The features of the frequency curves from Isachsen's Plateau and the Barnes Icecap correspond to the decidedly lower temperature in those localities, as compared to the Froya Glacier. A most important feature is that the frequency maximums on Isachsen's Plateau fell within the same temperature interval for the

15 Eriksson, op. cit., p. 26. 16 sverdrup, op. cit., p. 38 . 
three heights investigated ( 1.6 inches, 3.3 feet and 16.4 feet). This interval was $32.9^{\circ}-34.3^{\circ}$. On the Barnes Icecap the frequency maxima for the three heights $(3,13$ and 23 feet) also fell within the same interval, $32.1^{\circ}-36.0^{\circ}$. On the Fröya Glacier, however, the maximum frequency occurred at higher temperatures with increasing distance from the snow surface. This displacement of the maximum also occurs on the Karsa Glacier. This circumstance suggests that the supply of heat to the glacier by way of convection is especially large on the Froya and Karsa glaciers, in comparison with conditions on Isachsen's Plateau and the Barnes Icecap. Conditions are very similar in the latter two locations.

The Karsa and Froya glaciers are comparatively small. The Frolya Glacier is situated in a valley, and the air temperatures depend largely on heat radiation from surrounding land. The Karsa Glacier is also influenced by local conditions. These two glaciers are fairly similar in size and setting, as illustrated by a similar frequency distribution of temperature above the surface.

The frequency distribution of temperature over plateau glaciers and icecaps, like the Barnes and Isachsen's, shows the same characteristics in the different locations, and it is clear that over those icecaps there is only a relatively small amount of heat available for ablation by way of convection. When studying the frequency distribution of temperatures over the surface of the Penny Icecap (Figure 18) it is evident 
that the main characteristic of icecap distribution is present there also: the frequency maximum falls within the same temperature interval for all three heights and there is no displacement of the maximum. The conditions are favourable for lowering the air temperatures above the surface on all the icecaps. The surface melts for a relatively long period on the Barnes Icecap and on Isachsen's Plateau; the maximum frequency therefore falls just over $32^{\circ}$. No such continuous melting period was experienced on the Penny Icecap, where the maximum frequency fell in the interval $24^{\circ}-26^{\circ}$. Camp Al on the Penny Icecap was situated so high above the firn line that only sporadic ablation took place. This fact is important in our investigations of the conditions on the Penny Icecap. The interrupted, short periods of ablation can be studied in detail, with few disturbing factors, because of their short duration. As a preliminary conclusion it may be stated that the supply of heat to the icecap by way of convection is small.

Temperature and wind direction. The relation between temperature and wind direction is seen by the following compilation.

\section{TABLF 27}

WIND DIRECTION AND MEAN TEMPERATURE AT THREE FEET ABOVE SURFACE

Wind from: $N \quad N E \quad E \quad S E \quad S \quad S W \quad W \quad N W$ Calm

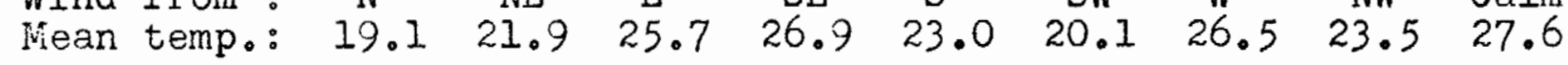

This table gives the means of all daytime temperatures recordings with the main wind directions. There is no direct 
relation between wind direction and temperature, because the distribution of wind directions was unequal throughout the period. In May and early June, when all the surrounding land was snow covered, southwest and south winds were very frequent. These directions therefore show a relatively low mean temperature. West and southeast winds were rather cornmon during the short periods of ablation, when the air temperatures reached several degrees above the melting point. The number of cases recording north wind was negligible, totalling only 1 per cent of all observations.

Both temperature and wind is controlled by the general pressure distribution in the area. As was found in a similar investigation into the relation between temperature and wind direction on the Barnes Icecap, it is the time of occurrence, (early or late in the season) and the the cloud conditions that govern the temperature-wind direction relationship. The season's barometric pressure distribution is the most important factor: indeed, an indication of a purely geographic control cannot be observed in the temperature readings. The mean temperature with winds from SW-S-SE was $21.9^{\circ}$, while the mean temperature with winds from $\mathrm{NW}-\mathrm{N}-\mathrm{NE}$ was $22.4^{\circ}$.

Diurnal variation of temperature. The average march of temperature through the day at the three levels is shown in Table VII. The means for 1600 and 1800 at thirteen feet for the eleven days of May, and the mean for 1800 at twenty-three feet have been omitted as only three measurements were undertaken. The reasons 
for this dearth of observations in the early period were various, such as general work connected with the establishment of the camp, erection of radiation instruments, installation of thermistors, etc. The other values given in the table are averages for the months, and for August the averages are given of the nine measurements undertaken at each height before the camp was evacuated on August 10th.

These mean temperatures are set forth in Figures 19, 20 and 21. Figure 19 shows the temperature variations at three feet. July days were warmest, but the means of all two-hourly temperature readings throughout the day stayed well below freezing. The first nine days of August had temperatures very similar to the average for July and a longer period of observation would presumably have given a result similar to that on the Barnes Icecap. There August days were warmer than June days, but several degrees colder than July days. 17 Figure 19 shows that the temperatures were steady throughout most of the day in July and early August; in June and late May the conditions were rather more complicated, the daily maximum occurring at differing times with the result that May shows the highest mean temperature at 1200, while June had the highest mean temperature at 1600. The fact that the eleven days of May show a higher mean temperature than June days before 1400 is fictitious, indicated by the stippled curve from 0800 to 1400 . A few temperature readings were missed during the Barnes Ice-Cap in 1950," Geografiska Annaler, Vol. 30, Ht. 3-4, 1951, p. 190 . 
MEAN TEMPERATURE AT TWOHOUR INTERVALS AT $3^{\prime}$

30

28

86

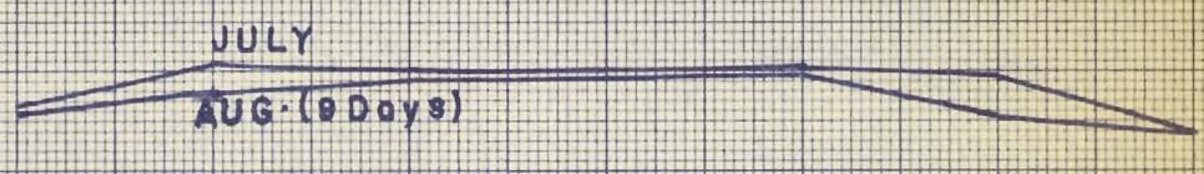

24

28

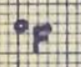

20.

16

16

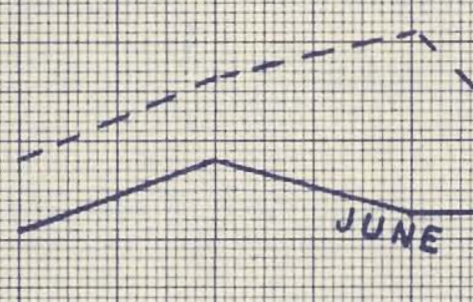

14

12 


\section{FIG 20}

MEAN TEMPERATURE AT TWOHOUR INTERVALS AT $13^{*}$

30

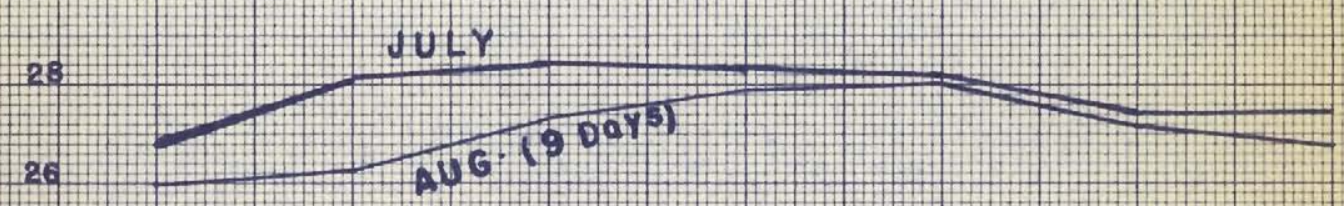

24

20

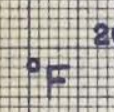

18

15

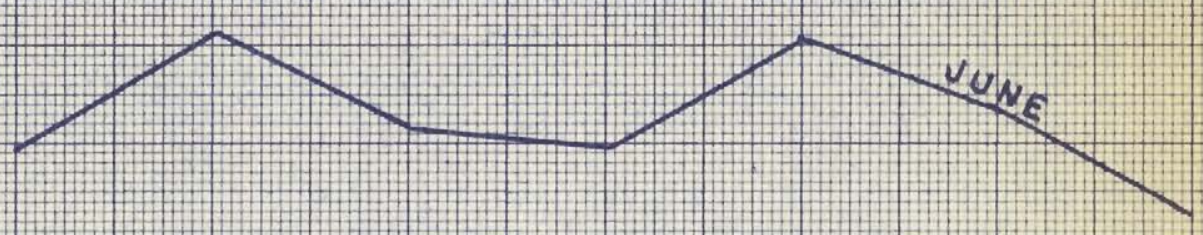

14
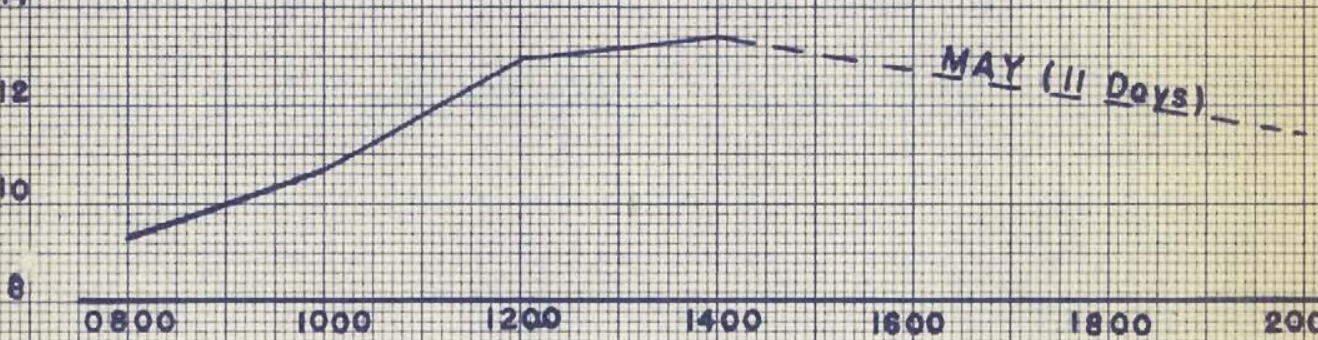


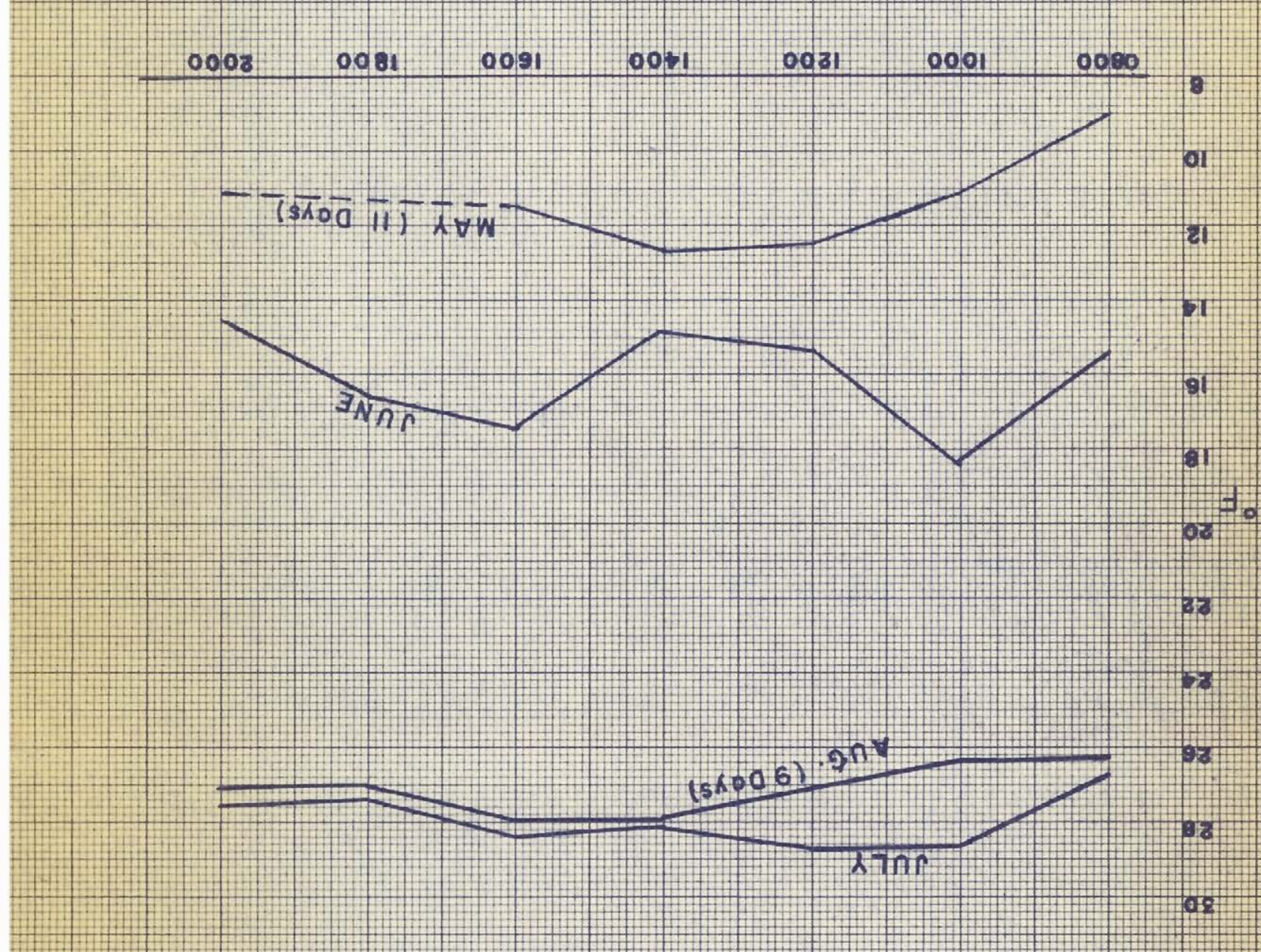

, ¿己 IV STVAYIINI צกOH

$-0 M \perp$ IV $38 \cap 1 \vee y 3 d W 3 \perp$ NV $W$

$12 \cdot 911$ 
blizzard of May 28th-29th. The curve for the last eleven days of May should, in fact, run several degrees below the June curve.

Figure 20 shows that the temperature conditions at thirteen feet were rather similar to those at three feet. The average daily maximum fell around 1400 in late May. In July and early August the temperatures were rather steady throughout the day, similarly to that found at three feet. Only the daily march of temperature in June shows irregularities, and these are found to be present also in Figure 21, which shows the temperatures at twenty-three feet above the surface. The average June temperatures at all three levels are lower at 1200 and 1400 than at 1000 and 1600. The average maximum at three feet was recorded near 1600, at thirteen feet and twenty-three feet near 1000. There is no common factor which explains this drop of average temperature between 1000 and 1600 in June. It took place on a total of eight days; on some clear calm days, on some foggy calm days, and on some days with strong steady winds.

The thermograph records also show that the diurnal variation of temperature was irregular. On the Barnes Icecap it was found that the diurnal variation was fairly well defined, both on days when the temperatures were partly or completely below freezing, as well as on days with above freezing temperatures only. ${ }^{18}$ On Isachsen's Plateau in West Spitsbergen Sverdrup $^{19}$ found that the temperature showed a well defined diurnal

18 Ibid., po 191.

$19 \mathrm{H}$. U. Sverdrup, "Results of the Meteorological Observations on Isachsen's Plateau," Geogratiska Annaler, Vol。18, Ht. 1,1936, p. 38 . 
variation on days when it was partly or completely below freezing, but that on days with only above freezing temperatures the diurnal variation was irregular.

The irregular diurnal variation of temperature on the Penny Icecap is demonstrated by means of the following compilation, which for two groups shows the mean temperature at every second hour throughout the day at the three heights.

TABLE 28

MEAN TEMPERATURE EVERY SECOND HOUR ON SEVEN DAYS WITH ABOVE FREEZING TEMPERATURES ONLY

\begin{tabular}{llll} 
Hour & $3 \mathrm{ft}$ & $13 \mathrm{ft}$. & $23 \mathrm{ft}$. \\
\hline 0800 & 33.9 & 34.2 & 34.6 \\
1000 & 34.2 & 34.3 & 34.8 \\
1200 & 34.4 & 35.0 & 35.3 \\
1400 & 35.2 & 35.8 & 36.3 \\
1600 & 35.2 & 35.7 & 35.9 \\
1800 & 35.4 & 36.0 & 36.2 \\
2000 & 35.0 & 35.7 & 36.2
\end{tabular}

TABLE 29

MEAN TEMPERATURE EVERY SECOND HOUR ON SEVEN DAYS WITH BELOW FREEZING TEMPERATURES ONLY

\begin{tabular}{llll} 
Hour & $3 \mathrm{ft}$. & $13 \mathrm{ft}$. & $23 \mathrm{ft}$. \\
\hline 0800 & 24.3 & 23.5 & 23.4 \\
1000 & 25.0 & 23.4 & 24.1 \\
1200 & 25.3 & 23.3 & 23.8 \\
1400 & 25.9 & 25.6 & 25.6 \\
1600 & 26.4 & 26.2 & 26.2 \\
1800 & 25.1 & 24.4 & 24.8 \\
2000 & 24.6 & 24.5 & 24.9
\end{tabular}

Figure 22 shows the conditions in the two cases. On days with above freezing temperatures only, the surface remained at a temperature of $32^{\circ}$, and the variation of air temperatures in the course of the day was due to the mainly unperiodic changes 
$-79-$

\section{FIG 22}

MEAN TEMPERATURE AT TWO-HOUR

INTERVALS ON SOME SELECTEDDAYS

37
36
36

3

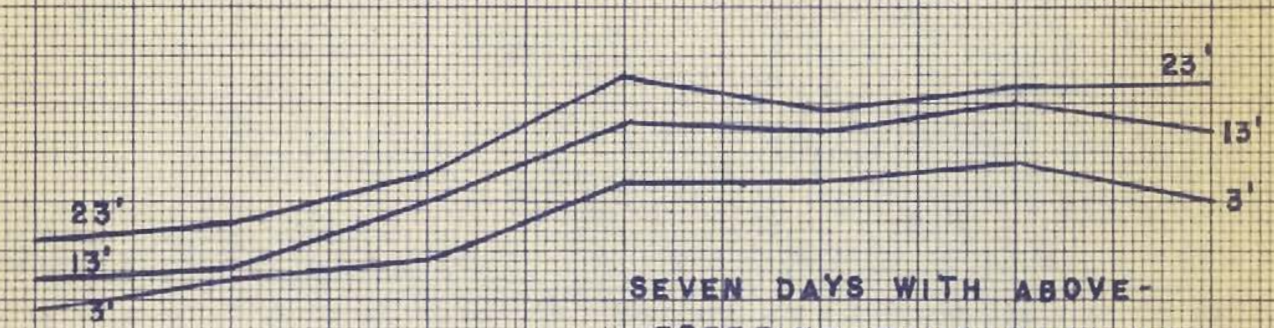

33

SEVEN DAYS WITH AGOYE-

FREEZING TENPERATURES

31

${ }^{\circ} \mathrm{F}=30$

29

28

SEVEN DAYS NITH DEL OW.

FREEZING TEMPERATURES

27

26

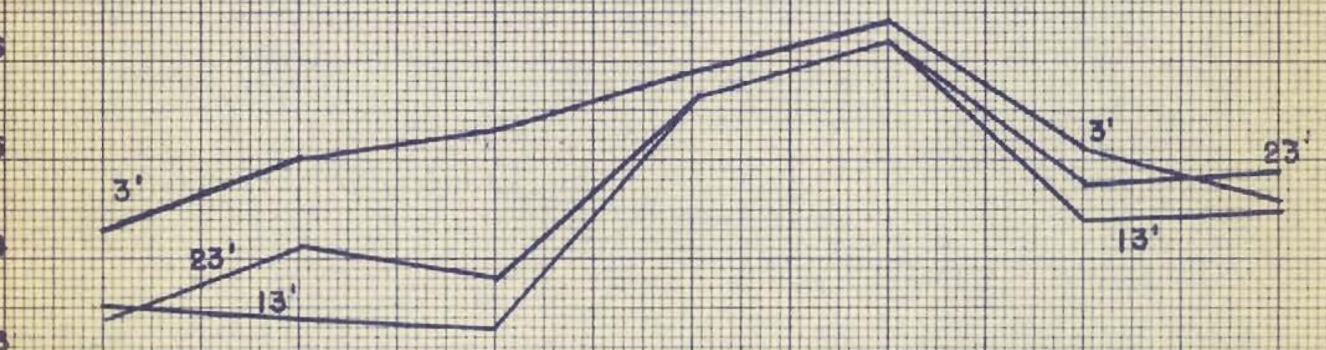

23

$0800 \quad 1000$

1200

1400

1600

1800

2000 
in the temperature of the air masses which moved over the icecap. On days with above freezing temperatures only, the air was stable below twenty-three feet. As shown in Table 25 (p. (4) the coldest period had the most unstable conditions, and this was the case on individual days as well, as can be seen in Figure 22 (below)。 On days with only below freezing temperatures the surface was frozen throughout the day and the surface temperature could, therefore, sink to low values, but could not rise above $32^{\circ}$. The diurnal variation was even more irregular than in the case of days with above freezing temperatures only, and the importance of unperiodic changes in the temperature of the air masses is greater over snow surfaces at high altitudes (the Penny Icecap) than over snow and ice surfaces at lower altitudes (the Barnes Icecap and Isachsen's Plateau).

Over the lower icecaps the stratification is also stable, on the whole, even on days with only below freezing temperatures, at least below thirteen feet. In the majority of cases the air is stable up to twenty-three feet, over the lower icecaps, and stability prevails. Over the surface of a high-lying icecap it is to be expected that the cold days (below freezing) have unstable conditions, and only the warmest periods will show stable conditions. 20

Temperature at the edge of the icecaps. The conditions at the southern edge of the Barnes Icecap were found to be ideal for an investigation into the differences in air temperatures 
over short distances. Simultaneous readings were carried out at the icecap station and at another glaciological camp on the bare land just off the southern edge of the icecap. It was found that during the period when the land is free of snow, the effect of the icecap on the climate of the surrounding land is surprisingly small. 21 The air temperatures near the surface depended more on the amount and absorption of radiation. Temperature readings on the Seward Glacier in Alaska showed that the temperatures averaged six to ten degrees $F$. lower on the glacier than at the camp site, which was on a rock crest of a nunatak in the middle of the glacier. Minimum temperatures at the glacier airstrip, 350 feet lower and two and one half miles from the research station, were found to be as much as fifteen degrees lower than those observed at the station. ${ }^{22}$ The important factor for the sumner temperature conditions is the presence of snow-free ground during periods of insolation.

The Barnes Icecap was found to have no influence on the fog formation and amounts of sunshine recorded over the surrounding land. After the land became snow covered the difference in temperature between the edge of the ice and the nearby land became negligible. No such instrumental investigation was undertaken near the edge of the Penny Icecap. This icecap in its northwestern parts is somewhat similar to the Barnes Icecap,

21 Orvig, op. cit, p. 195.

22 W。A.Wood, "Project Snow Cornice," Arctic, Vol. I, No. 2, Autumn, 1948, p. 111 . 
but in its southeastern part, where the 1953 Expedition was working, the icecap covers high plateau mountains and spills thick ice into steep valleys. It is possible, however, to judge the influence of the icecap on the climate of the surrounding land from observations made by expedition members who travelled near the edges of the outflowing glaciers. P. D. Baird travelled from Camp Al on July 2nd and returned on July 4 th, having investigated a lake at the southern edge of the icecap ten miles southwest of the icecap station. This lake was approximately 3080 feet above sea level, and it was covered with ice fortyfour inches thick. The vegetation close to the icecap edge included potentilla, heather (in flower), willows and some shortstemmed popples. The shade temperature at about 1 pomo was $55^{\circ} \mathrm{F}_{0}{ }^{23}$ The vegetation was observed also on the trip down Coronation Glacier when the icecap station was evacuated. Close to the ice surface on steep rock walls large areas were coloured green from mosses, lichens, Saxifrage and other pioneer flowerIng plants, proving the importance of radiation and snow-free ground in raising the air temperatures, in spite of the nearby cold ice masses. On numerous occasions, when thick fog was covering the dome where the icecap station was situated, a short run on skis down the north side of the dome towards Coronation Valley would take one under the fog. The domes of the icecap and its main body, stretching northwestwards, could not be seen because of fog, but the outer edges of the domes and the snow- 
free ground were in the clear. Regardless of altitude, it seems that the icecaps and glaciers in Baffin Island exercise very little control over the climate of the surrounding land.

\section{II。 HUMIDITY}

Humidity measurements were carried out every second hour, from 0800 to 2000 daily, at three feet above the surface. The humidity was observed by means of a Casella Assmann aspirated psychrometer, and a continuous trace of relative humidity was obtained by the thermo-hygrograph. Both of these methods are unsatisfactory at low temperatures, as the difference is then small between the wet and dry bulb readings, and the lag of the hair hygrograph becomes greater.

In winter the relative humidity of the air over the ice in the Arctic Ocean always remains near 100 per cent. The lowest value observed by Mialmgren in 1923-25, during the Norwegian North Polar Expedition in the "Maud", was 83 per cent, and the highest value was 122 per cent. Supersaturation was met with at low temperatures, low wind velocities and clear skies. 24 Supersaturation was frequently experienced on the Penny Icecap, but only with low temperatures and fog. When the air temperatures were close to the freezing point difficulties were also experienced in measuring the humidity, especially on the few occasions when the air was relatively dry. Sverdrup ${ }^{25}$ has pointed out the

$24 \mathrm{R}$.W. Rae, Climate of the Canadian Arctic Archipelago, p. 35, citing $H_{0}$ U。 Sverdrup, Meteorology, The Norwegian North Polar lixpedition with the Maud" 1918-25, Vol。 2, Part 1, Bergen, 1935, p. 250。

$25 \mathrm{H}$. U. Sverdrup, "The Eddy Conductivity of the Air over a Smooth Snow Field," Geofysiske Publikasjoner, Vol. 11, No.7, Oslo, 1936, p.26. 
difficulties encountered in the humidity measurements on Isachsen's Plateau at temperatures around freezing point, when the adjustment to the correct temperature reading took a long time. When the water which is applied to the muslin cover of the wet bulb freezes, the adjustment is especially slow. Sverdrup found that directly above the snow surface on Isachsen's Plateau the air was, as a rule, saturated with water vapour, but at greater distances from the surface the air could be very dry. On the average the relative humidity decreased with height, but the vapour pressure increased somewhat since the temperature increased with height. 26

On the Barnes Icecap the relative humidity was measured at three feet and at twenty-three feet above the surface with a sling psychrometer. Great difficulties were experienced, especially near the freezing point, and also due to the thermometers of the sling psychrometer being unprotected from radiation. On Wegener's crossing of Greenland comparisons were made between Assmann and sling psychrometer readings, and it was found that in sunny weather the sling psychrometer readings were up to 1.2 degrees C. too high. 27

The measurements of humidity have caused difficulties to

26 H. U. Sverdrup, "Results of the Meteorological Observations on Isachsen's Plateau," Geografiska Annaler, Vol。 18, Ht. 1,1936, p. 41 .

$27 \mathrm{~J} . \mathrm{P}$. Koch and A。 Wegener, "Wissenschaftliche Ergebnisse der Dänischen Expedition nach Dronning Louises Land und quer Uber das Inlandeis von Nordgrönland 1912-1913, "Meddelelser om Grönland, Bd. 75, Part 2, Copenhagen, 1930, p. 539. 
all investigators on glaciers and icecaps. Wallen ${ }^{28}$ mentions the fact that the registrations of humidity on the Karsa Glacier were far more uncertain than those of temperature, and errors in the values of relative hunidity up to 5 to 10 per cent are possible.

On the Penny Icecap attempts were made, on May 21 st and 22nd, to start regular humidity measurements at thirteen and twenty-three feet. It was found that the air was saturated to the highestlevel, and numerous attempts throughout the period failed to prove a great difference between the lowest and highest levels. It must be borne in mind that the air temperatures increased with height over the Penny Icecap surface for only 17 per cent of the time; for the rest of the time even a decrease in vapour pressure would not reduce the relative humidity at height, because the air temperature decreased. Even on days with increasing temperature at height over the surface, a definite humidity gradient could not be measured.

The relative humidity as observed at three feet is given in Table VIII. A certain diurnal variation of the relative humidity was not observed. Because of the difficulties experienced, and the uncertain results of the humidity measurements, no attempt has been made here to calculate the absolute humidity or water vapour pressure. The mean value of relative humidity for the whole period of investigation was 93.1 per cent.

$28 \mathrm{C} . \mathrm{C}$.Wallen, "Glacial-Meteorological Investigations on the Karsa Glacier in Swedish Lappland 1942-1948," Geografiska Annaler, Vol. 30, Ht. 3-4, 1948, p. 501. 
The values given in Table VIII are set forth graphically in Figure 23. Close to the snow surface the air was, as a rule, saturated. There the relative humidity always stayed close to 100 per cent. On the Barnes Icecap relative humidities as low as down to 50 per cent were occasionally observed at the height of twenty-three feet. There the relative humidities decreased sharply with height during June and July. The decrease in relative humidity with height was less in August, corresponding to the period with persistent fog。 On the Penny Icecap fog was persistent all through the observation period, and only very few days showed a drop in relative humidity with height. On the Barnes Icecap it was found that the periods with relatively low humidity at two levels corresponded to the periods with mean daily temperature above the freezing point. 29 A comparison of Figures 23 and 9 shows no correlation between mean daily temperature and mean daily relative humidity on the Penny Icecap.

Humidity and wind direction. The relation between humidity and wind direction is seen in the following compilation.

\section{TABLE 30}

WIND DIRECTION AND MEAN RELATIVE HUMIDITY AT THREE FEET ABOVE SURFACE

Wind from: $N \quad N E \quad E \quad S E \quad S \quad S W \quad W \quad N W$ Calm Rel. Hum.\%: $88.392 .595 .296 .092 .793 .9 \quad 87.3 \quad 92.0 \quad 84.0$

29 S. Orvig, "The Climate of the Ablation Period on the Barnes Ice-Cap in 1950," Geografiska Annaler, Vol. 33, Ht. 3-4, 1951, p. 198。 


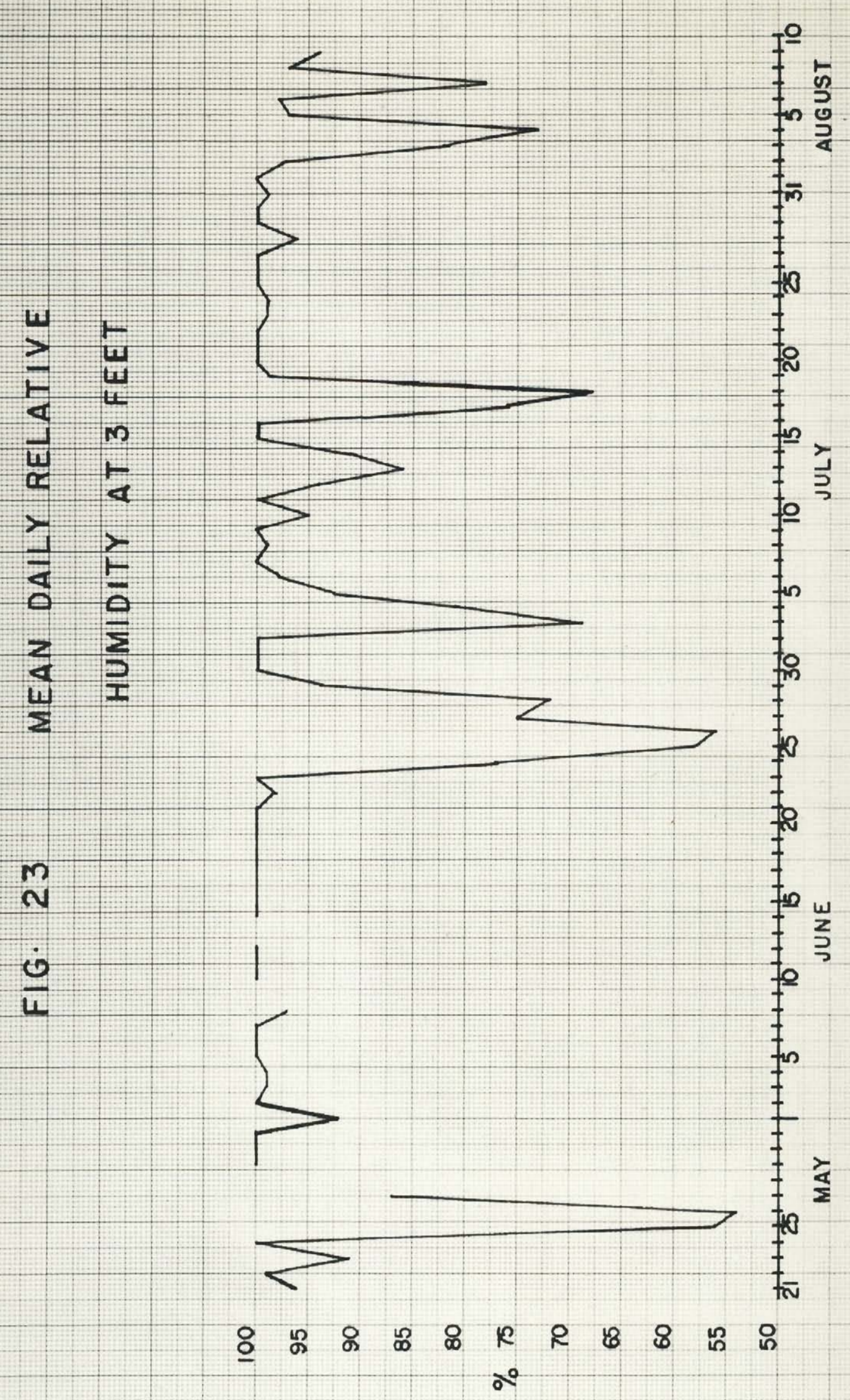


The observations of calm weather and of northerly wind were few compared to the other directions; the relatively low values of mean relative humidity in these two cases are therefore probably not representative. Otherwise the westerly winds had the lowest relative humidity, and the southeasterly winds had the highest relative humidity. Similar investigations on the Barnes Icecap ${ }^{30}$ gave the result that the warmest winds had the lowest relative humidity, and conversely the coldest winds had the highest relative humidity。

By comparing Tables $27(p, 71)$ and 30 it is seen that similar conditions were not found on the Penny Icecap. The westerly winds, with the lowest relative humidity, were among the warmest, but the southeasterly winds, on the other hand, were the warmest and yet had the highest relative humidity。

\section{III。WIND}

Wind observations were carried out every two hours, from 0800 to 2000, at six feet above the surface. A hand anemometer was used to measure the wind speed, while direction was observed with the help of a wind vane on top of the observation mast. No recording instruments were available to measure the wind at night. Owing to the position of the camp on top of the highest dome, and the distance of more than fifteen miles to the nearest higher land, no local factors influenced the wind.

On the Barnes Icecap it was found that on a few occasions

30 Orvig, 10c.cit. 
a down-slope wind was noticeable at the surface, while the upper wind came from the opposite direction. This lower wind probably corresponds to the "Schwerewind" (Katabatic wind) which is observed over most glaciers and has been especially investigated in Greenland. ${ }^{31}$ sverdrup ${ }^{32}$ also described occurrences of geostrophic flow down the slope of Isachsen's Plateau on clear nights with outgoing radiation. Eriksson measured a lower wind below two to four meters, with a direction opposite to that of the wind above two to four meters, on the Froya Glacier. ${ }^{33}$ On no occasion was a similar thin layer of air (below six to thirteen feet) observed moving down-slope on the Barnes Icecap, and on the occasions of measurements at two levels on the Penny Icecap the direction of the wind at the two levels always corresponded. The presence of fog frequently prevented observations of clouds over the Penny Icecap, but it was never observed that the direction of the wind at twenty-three feet differed from the direction of the upper wind as observed by the drifting clouds.

The frequency of the different directions is seen in the following table.

$31 \mathrm{~K} \cdot W e g e n e r$, "Zusammenfassung der Wissenschaftlichen Ergebnisse," Wissenschaftliche Ergebnisse der Deutschen Grönland Expedition Alfred Wegener I929 und 1930-31, Band VII, Leipzig, I940.

$32 \mathrm{H}$. U. Sverdrup, "Results of the Meteorological Observations on Isachsen's Plateau," Geografiska Annaler, Vol. 18, Ht. 1, 1936, p. 36 .

33 B. E. Eriksson, Meteorological Records and the Ablation on the Froya Glacier in Relation to Radiation and Meteorological Conditions," Geografiska Annaler, Vol. 24, Ht. 1-2, 1942, p. 27 . 
TABLE 31

NUMBER OF OBSERVATIONS, AND THE PERCENTAGE FREQUENCY OF THE DIFFERENT DIRECTIONS

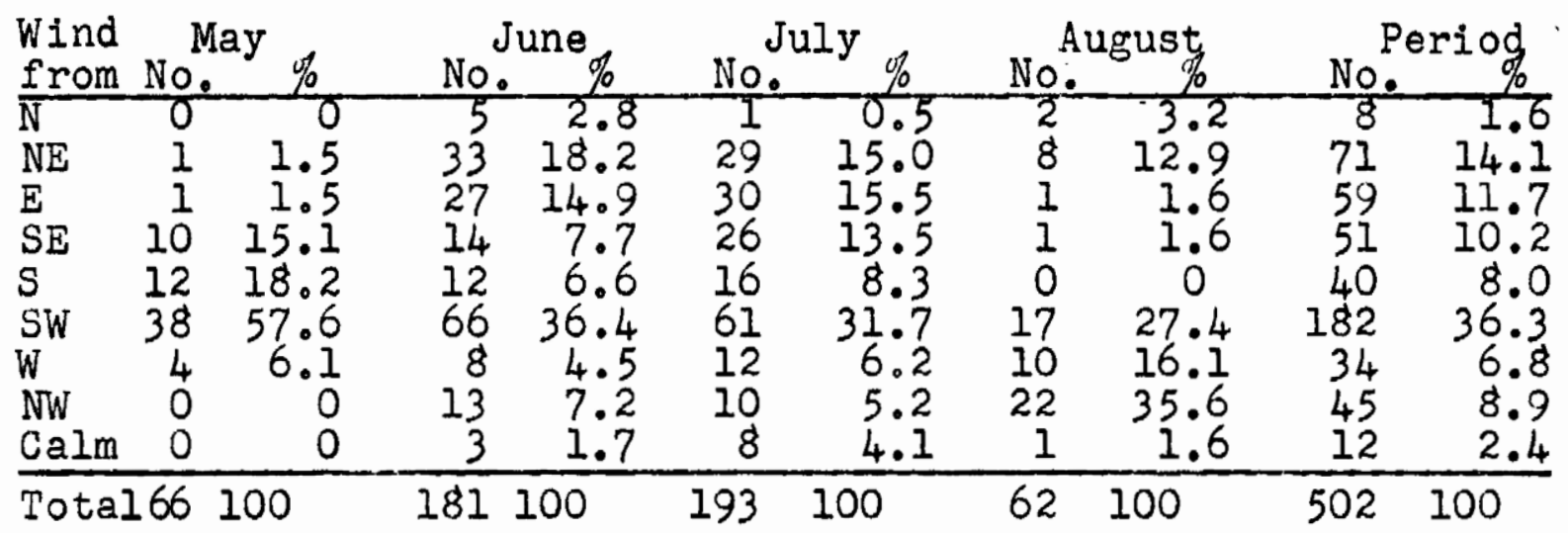

Figure 24 shows the percentage frequency of different wind directions for each month and for the whole period. The predominant direction was southwest. The months of June and July had frequent east and northeast winds, but southwest winds were twice as frequent even in those months. The first nine days of August saw an increase in west and northwest winds. The frequency of southwest wind decreased slowly during the summer, but the percentage frequency for the whole period shows that more than one third of the time had southwest wind. It is strikingly clear from Figure 24 that the wind conditions were very similar in June and July, and the resultant wind rose for the whole period is therefore similar to those for June and July. There was no topographical control of wind direction on the Penny Icecap. The wind directions were due to the pressure distribution alone. The pressure will be discussed in the next paragraph. The mean daily values of wind speed (the averages of 


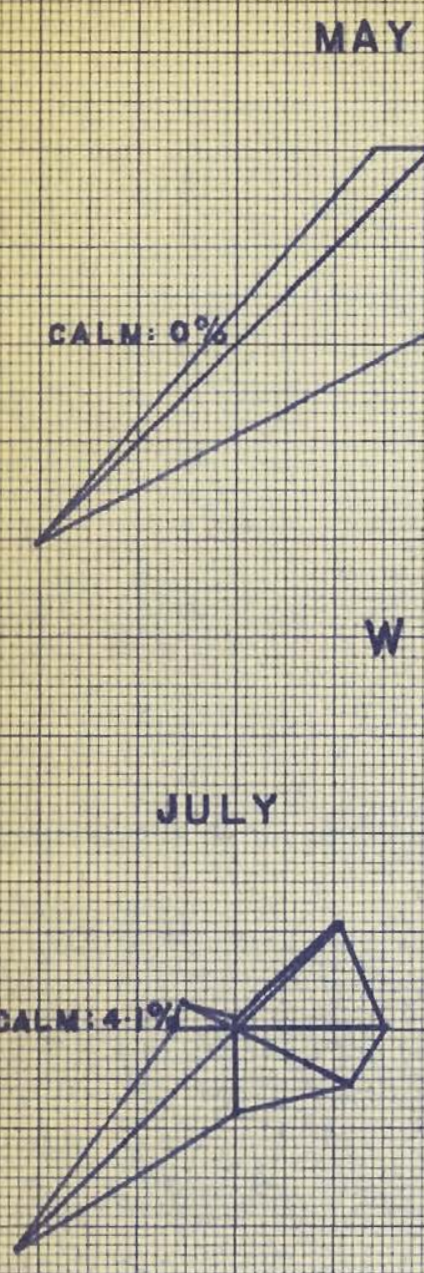

JUNE

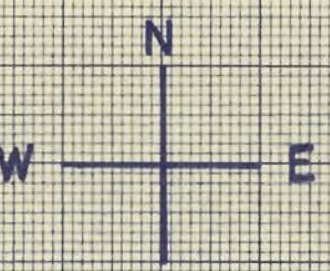

s

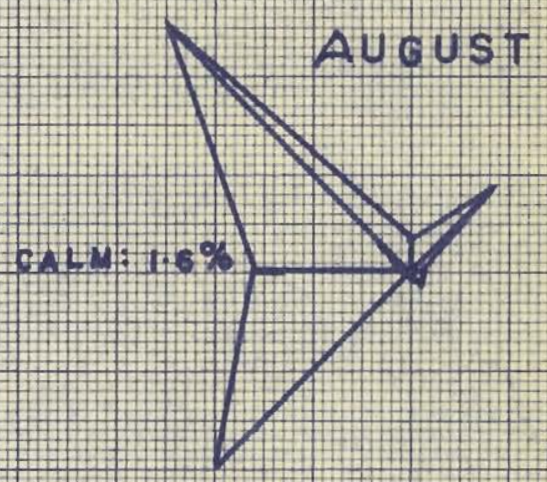

\section{PERIOD}

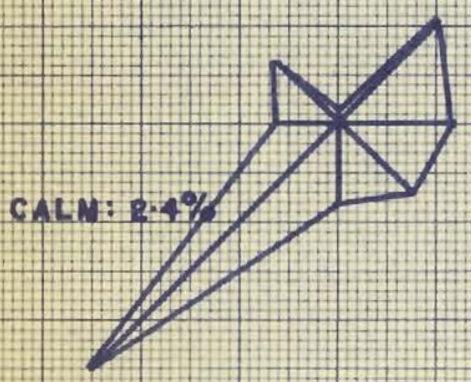

\author{
FI G. 24 \\ WINDROSES \\ (DIRECTION)
}


seven daily wind observations at six feet) are listed in Table IX. The average wind decreased steadily from $16.1 \mathrm{mph}$ for the last eleven days in liay, through $9.3 \mathrm{mph}$ for June, and $8.7 \mathrm{mph}$ for July, to $7.7 \mathrm{mph}$ for the first nine days in August.

The wind speeds with the different wind directions are given in the following table.

\section{TABLE 32}

WIND DIRECTION AND MEAN WIND SPEED AT SIX FEET ABOVE THE SURFACE

$\begin{array}{lcccccccc}\text { Wind from: } & N & N E & E & S E & S & S W & W & N W \\ \text { Wind speed: } & 10.5 & 6.9 & 7.0 & 9.5 & 9.6 & 11.6 & 10.7 & 7.0\end{array}$

This relationship between wind direction and speed is shown in Figure 25, which indicates that there was little difference in the wind speeds from the different directions; the west and southwest winds were the strongest, and the difference between the highest and the lowest averages was $4.7 \mathrm{mph}$.

The average wind speed for the whole period was $9.8 \mathrm{mph}$, which is not unduly high considering the altitude of the station. The maximum recorded wind speed was $36 \mathrm{mph}$. The wind speeds were quite high during the summer of 1950 on the Barnes Icecap, where the average wind speed at seven feet was $9.7 \mathrm{mph}$, and the maximum recorded wind speed at the same height was $37 \mathrm{mph}$.

In order to compare the wind observations with similar data from North East Greenland and Spitsbergen, the wind speeds are, in the following, converted to meter/sec. and the heights to $\mathrm{cm}$. 


\section{F16. 25 \\ WINDROSE \\ (SPEED)}
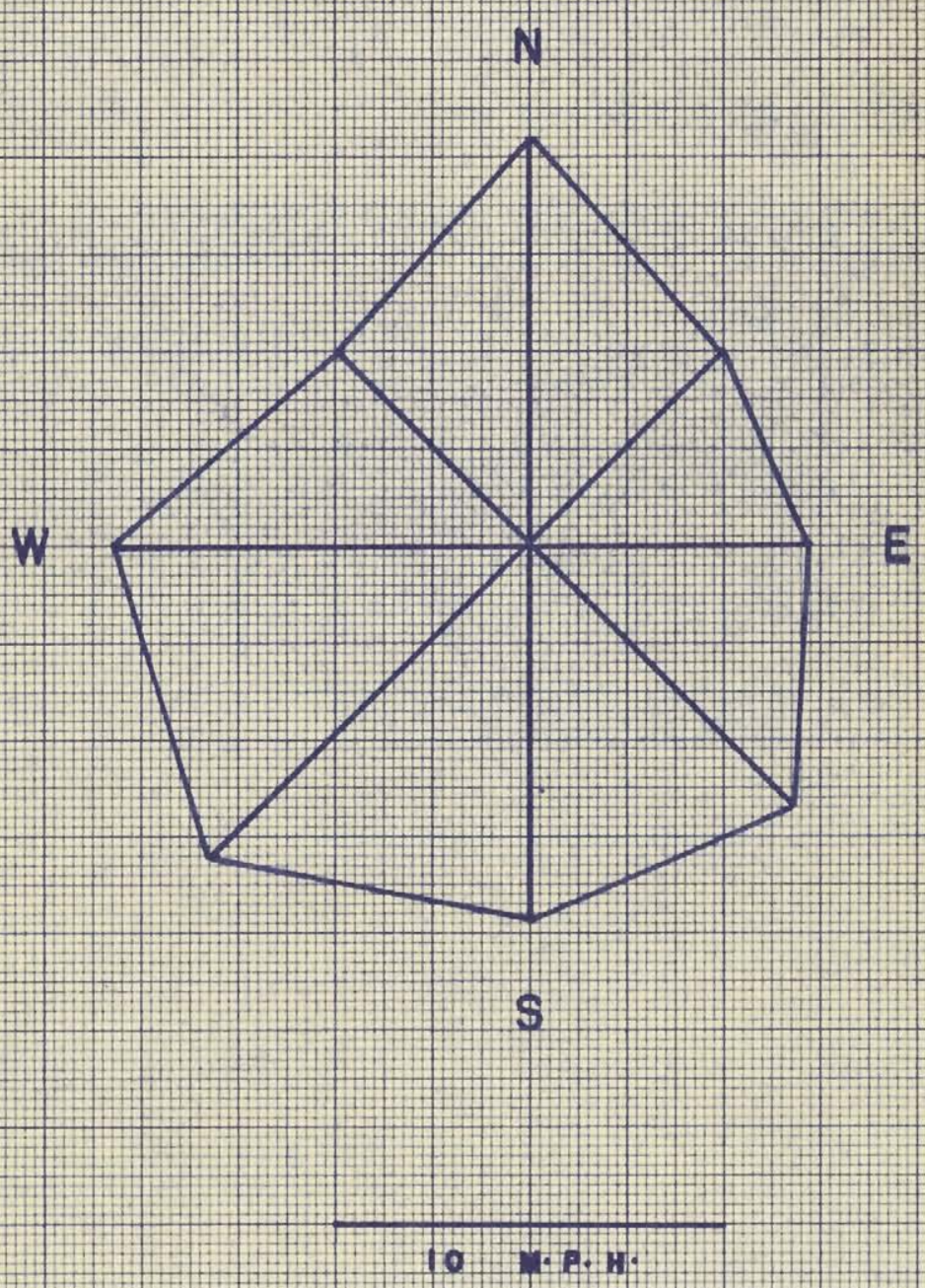
Penny Icecap, period May 2lst to August 9th:

Height in $\mathrm{cm}$. above surface:

Average wind speed in $\mathrm{m} / \mathrm{sec}_{0}:$

Maximum wind speed in $\mathrm{m} / \mathrm{sec}_{0}$ : 183 4.4 16.1

Barnes Icecap, 34 period June 1st to August 26th:

Height in $\mathrm{cm}$. above surface:

Average wind speed in $\mathrm{m} / \mathrm{sec}$ :

Maximum wind speed in $\mathrm{m} / \mathrm{sec}$ : $\frac{213}{4 \cdot 3}$ 16.5

Fröya Glacier, 35 period July 3 lst to August 18th: Height in $\mathrm{cm}$. above surface: Average wind speed in $\mathrm{m} / \mathrm{sec}_{0}$ : Maximum wind speed in $\mathrm{m} / \mathrm{sec}_{0}$ : 200 6.2

Isachsen's Plateau, ${ }^{36}$ period June 26th to August 15th:

Height in $\mathrm{cm}$. above surface: Average wind speed in $\mathrm{m} / \mathrm{sec}_{0}$ : Maximum wind speed in $\mathrm{m} / \mathrm{sec}$ : 200
2.7
8.1

Although the period of investigation on the Fröya Glacier was much shorter than the other three periods, it is nevertheless possible to compare the data from Clavering Island (the Fröya Glacier) at least with those from the Barnes Icecap. There was no difference in the wind speeds for the period July 31 st to Augrst 18th on the Barnes Icecap from the average for the whole summer:

$\frac{\text { Period: }}{\text { Average wind speed in } \mathrm{m} / \mathrm{sec}::-\frac{\text { August } 18 \mathrm{th}}{4.3} \text { June 1st to August 26th }}$

34 Orvig, op. cit., p. 200 。

35 Eriksson, loc. cit.

36 Sverdrup, 10c. cit. 
The wind was far stronger on the Barnes Icecap than on either Isachsen's Plateau (at a similar altitude) or the Froya Glacier. The reason was the frequent passages of cyclones near or over northern Baffin Island in the summer months of 1950 . The most frequent wind speed lay between four and ten mph, nearly half of all observations. 37

The station on the Penny Icecap was located almost four thousand feet higher than the camp on the Barnes Icecap. In spite of this, the wind speeds were almost identical at the two stations, and the lowest velocities were the most frequent also on the Penny Icecap, as evident from the following compilation. It shows that more than half of all observations gave wind speeds between two and ten mph.

\section{TABLE 33}

FREQUENCY OF DIFFERENT WIND SPEED INTERVALS IN PERCENTAGES OF THE TOTAL NUMBER OF MEASUREMENTS

Wind speed at six feet: $0-2$ 2.1-4 $4.1-6 \quad 6.1-8 \quad 8.1-10 \quad 10.1-12$ $\begin{array}{lllllll}\text { Percentage of obs. } 0.1 & 15.0 & 14.8 & 15.8 & 13.7 & 11.0 \\ \text { Wind speed at six feet: } 12.1-14 & 14.1-16 & 16.1-18 & 18.1-20 & >20\end{array}$ $\begin{array}{llllll}\text { Percentage of obs。: } & 5.1 & 4.6 & 5.9 & 2.7 & 5.3\end{array}$ The total number of wind speed observations was 474 .

A diurnal variation of wind speed was not observed, neither did the wind direction show any diurnal variation. The wind very closely followed the changes in pressure, as will be demonstrated in the next paragraph.

37 Orvig, loc. cit. 


\section{IV。 PRESSURE}

The pressure is the meteorological element least likely to influence the ablation, except indirectly by governing the wind speed and direction.

The problem of arctic circulation patterns has been studied by Dorsey. He has drawn average monthly sea level pressure charts, of which the July chart ${ }^{38}$ is the most important in the present study. His latest chart of mean pressure for July indicates a normal pressure at sea level in the region of the Penny Icecap of $1008 \mathrm{mb} .39$ This agrees with Rae's mean pressure chart for July。 40 The altitude of the icecap station was 6725 feet; using the normal value for the vertical pressure gradient, $4 \mathrm{mb} / 100$ feet, the normal pressure at Camp Al in July should be approximately $739 \mathrm{mb}$. The pressure was recorded in inches; the normal at Camp Al should then be approximately 21.82 inches. This is about 1.09 inches, or $37 \mathrm{mb}$, below the actual mean pressure for July, as recorded on the icecap. In this connection it may be of interest to refer to the pressure observations, at a lower altitude, on the Barnes Icecap. There the normal pressure at the station was found to be ten to fifteen mb higher than that

$38 \mathrm{H} \cdot \mathrm{G}$ 。Dorsey, Meteorological Characteristics of Northern Arctic America, thesis submitted for the degree of $\mathrm{M}_{0} \mathrm{Sc}_{0}$, Massachusetts Institute of Technology, 1949, fig。3, p. 27.

$39 \mathrm{H}$. G. Dorsey, "Arctic Meteorology," Compendium of Meteorology, American Meteorological Society, Boston, 1951, p.945.

40 R. W. Rae, Climate of the Canadian Arctic Archipelago. Toronto: Department of Transport, 1951, p.84。 
calculated, using the normal pressure gradient. 41

The averages of seven daily pressure readings are listed in Table $X_{0}$. It is possible that the aneroid may have recorded a little too high, but the variations in pressure may nevertheless be studied, and the daily pressure for the whole period is therefore set forth in Figure 26. The mean pressure for the whole period was 22.86 inches, and it will be seen that the only long, continuous period with below-average pressure lasted from June $3 \mathrm{rd}$ to June $23 \mathrm{rd}$, with the lowest mean pressure 122.39 inches) on the 14th. This period was in turn followed by the period June 24 th to July 9 th, with the highest mean pressure on July 2nd and 3 rd (23.21 inches). Figure 26 also shows the mean wind speed every day at the icecap station. These daily values are the averages of seven daily wind observations at six feet and are listed in Table IX. The curves in Figure 26 demonstrate how the wind speed on the icecap is governed by changes in pressure. The only day with high pressure and relatively high wind speed was July 13 th.

Five periods stand out clearly: 1) May 2lst to June 3rd, with large daily pressure variations and mainly high winds, an average of $30 \mathrm{mph}$ on May $28 \mathrm{th}$;2) June 3 rd to June $23 \mathrm{rd}$, with low pressure and varying winds, the lowest recorded pressure occuring on June 14th; the previous day, which had steeply falling pressure, had an average wind of $30 \mathrm{mph}$; 3) June $23 \mathrm{rd}$ to

41 S. Orvig, The Climate of the Ablation Period on the Barnes Ice-Cap in 1950 , thesis presented for the degree of $\mathrm{M}_{0} \bar{S}_{0}$, McGill University, 1951, p.91. 


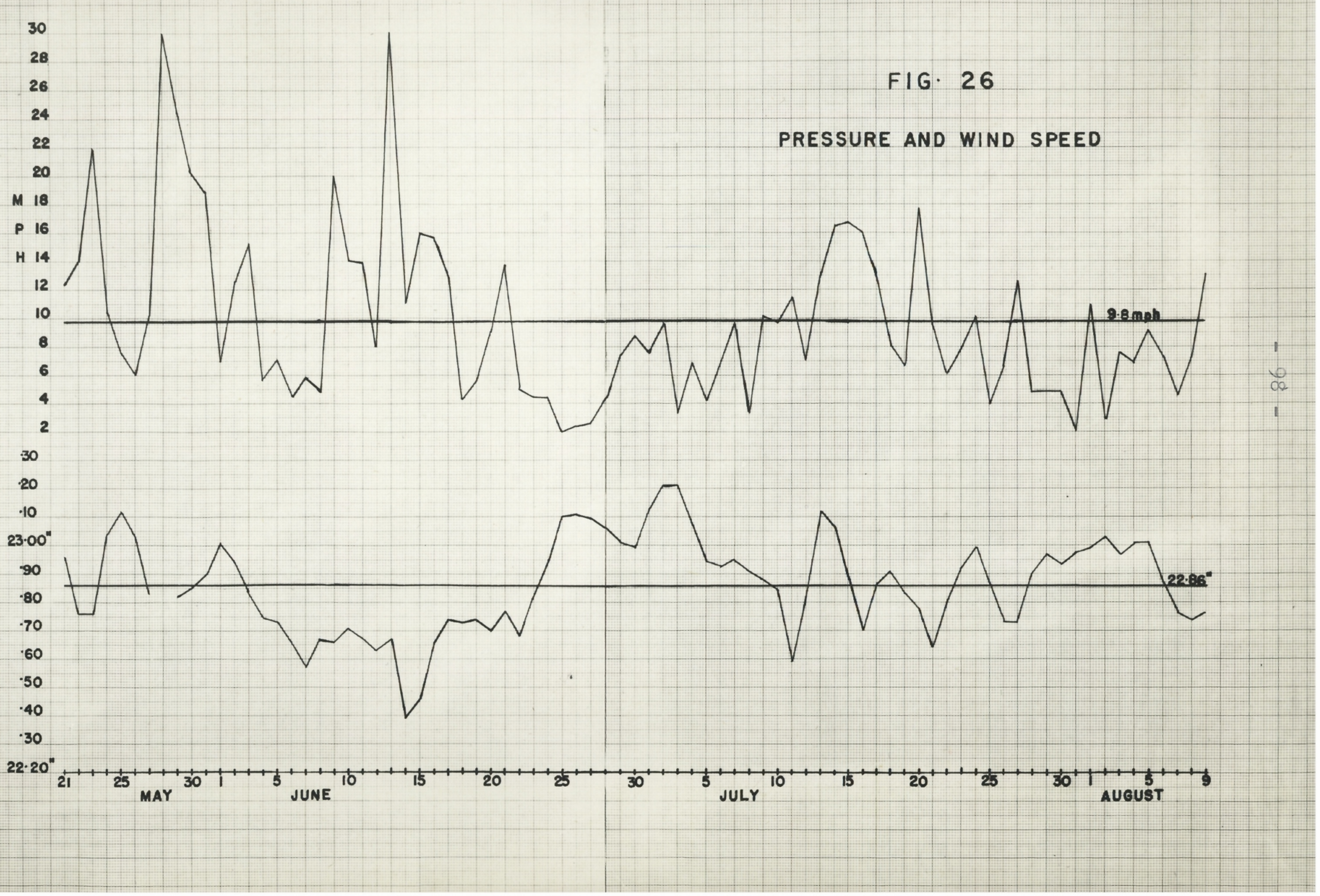


July loth, with high pressure and low winds; 4) July l0th to July 28 th, with large daily pressure variations and varying winds; 5) July 28 th to August 6th, with relatively high pressure and low winds.

The mean pressure distribution in summer in the eastern Canadian Arctic has been described by Hare。 42 The lowest pressure lies over southern Baffin Island and higher pressure over the Arctic Ocean. The resultant flow over most of the eastern Arctic is a cyclonic rotation from north Greenland and the Arctic Ocean. The abundance of relatively warm Maritime Polar air along the Baffin Island coast is readily explainable, as the resultant flow over Davis Strait is from south and southeast.

The northern parts of the eastern Canadian Arctic are more affected than the southern parts by the cyclones moving into the area from the region of the American Arctic frontal zone in summer. 43 The analysis of synoptic charts carried out by Hare showed that cyclonic flow dominates the whole Baffin Island area in July; the isopleth for 65 per cent frequency of cyclonic flow passes down the length of the island.44 The frequency of frontal activity, according to Hare, decreases abruptly northwards from Fort Chimo (50 per cent) to Clyde (20 per cent). The high frequency of cyclonic curvature, together with low

$42 \mathrm{~F} . \mathrm{K}$. Hare, The Climate of the Eastern Canadian Arctic and Sub-Arctic and its Influence on Accessibility, thesis presented for the degree of Ph.D, L'Universite de Thontreal, 1950, $p p=47-48$.

$$
\begin{aligned}
& 43 \text { Ibid., po50. } \\
& 44 \text { Ibid., figs。30,31, p. } 57 .
\end{aligned}
$$


frontal frequency, shows that non-frontal arctic cyclones are significant elements in the circulation. 45 Hare notes that the non-frontal cyclones are less common in summer than in winter, and that precipitation is rare in such systems.

On the Barnes Icecap, in latitude $69^{\circ} 42^{\prime} \mathrm{N}$, the precipitation was quite heavy at times, and a study of the synoptic charts of the summer of 1950 showed that at least two frontal systems crossed the region of the icecap, and the weather was. on several other occasions influenced by low pressure systems. 46

The precipitation on the Penny Icecap was not as heavy as that experienced on the Barnes Icecap. The following figures are the precipitation amounts measured for each of three periods with low, or varying, pressure and mainly high wind:

May 27 th to May 30 th : 2 inches snow

June 3 rd to June 23rd: 12.25 inches snow July loth to July 28 th: 14.63 inches snow, 0.83 inches rain.

The synoptic charts of the summer show that during the first period there was no frontal system in the neighbourhood of Baffin Island. There was only a steepening of the gradient between an extensive anticyclone moving eastwards across Hudson Bay and lingava, and a non-frontal cyclone over northern Baffin Island. Figure 27 shows the situation on May 29 th. The nine days in June, from the 6 th to the $15 \mathrm{th}$, saw three frontal pas-

45 Ibid., p. 58 .

$46 \mathrm{~S}$. Orvig, "The Climate of the Ablation Period on the Barnes Ice-Cap in 1950," Geografiska Annaler, Vol。33, Ht。3-4。 1951, pp. 203-06. 


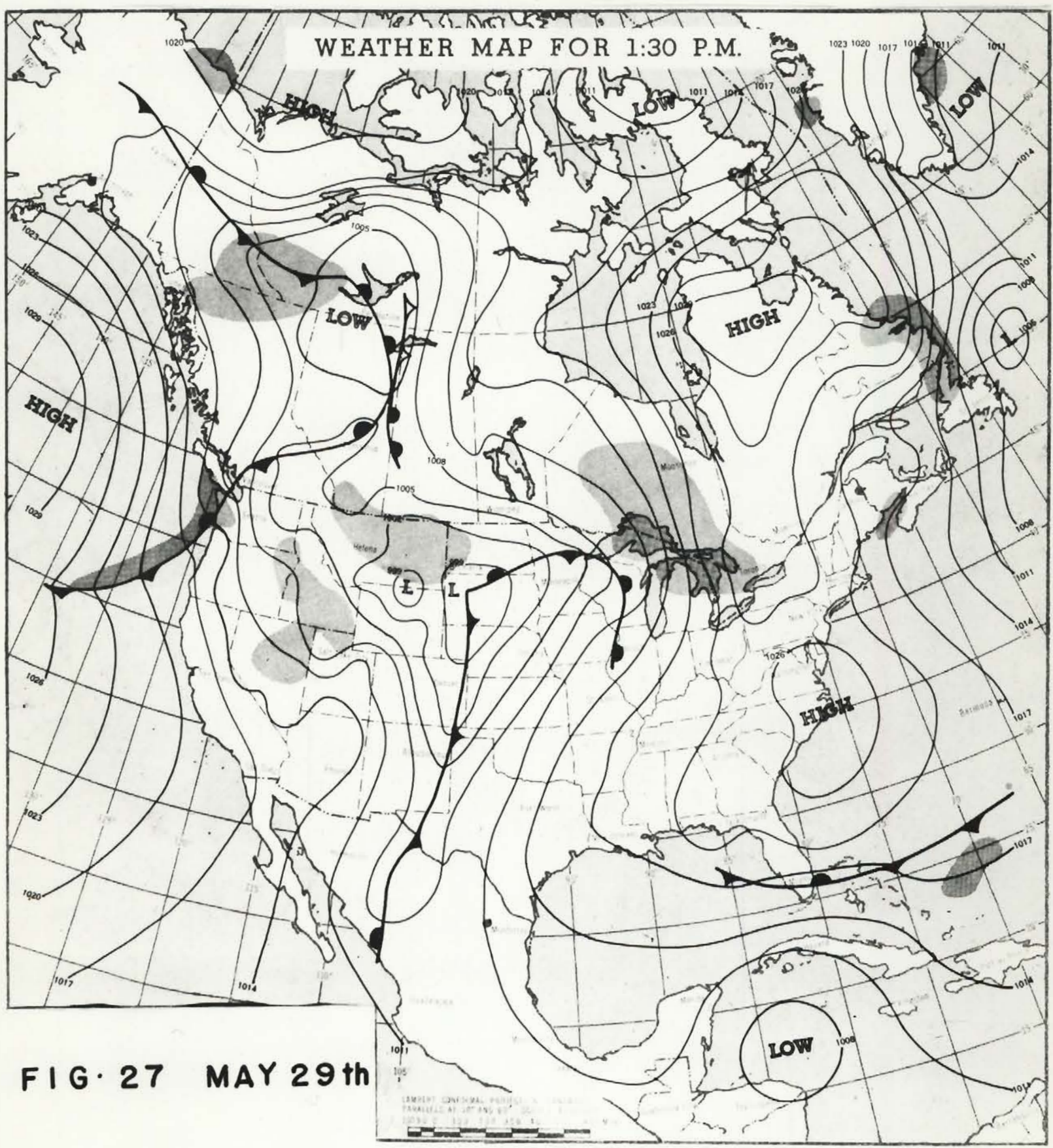


sages over Baffin Island. Figure 28 shows the situation on June 6th, with a cold front moving southeastwards over southern Baffin Island, and in Figure 29 the situation is shown as it was two days later. A new cold front was moving southeastwards from the western arctic islands. This front moved slowly, and had only passed Baffin Island four days later. By that time a new (stationary) front was forming over northern Alaska and the western Arctic. Figure 30 shows the situation on June 12th. The centre of the low pressure passed over the region of the icecap station on the evening of June $14 \mathrm{th}$, causing strong winds and snow. Figure 31 shows the situation on June 14th.

In July another three frontal passages influenced the weather in the Cumberland Peninsula. Figure 32 shows the situation on July 14th, with a cold front moving southeastwards over central Baffin Island. An occluded front passed from the southwest over the Cumberland Peninsula during the night of July 20th2lst, and Figure 33 shows the complicated situation on July 26th. A cold front was moving eastwards over Foxe Basin, and two low pressure systems were moving northeastwards from Ungava towards Greenland. It was found very frequently, especially in July, that the variations in pressure and wind speed were caused by movement of cyclones outside the area, with a general reduction in air pressure along the path of the cyclones, and a steepening of the pressure gradient. On a few occasions non-frontal cyclones formed to the north of the Cumberland Peninsula, but most frequently frontal cyclones travelled the path from northern Alberta 


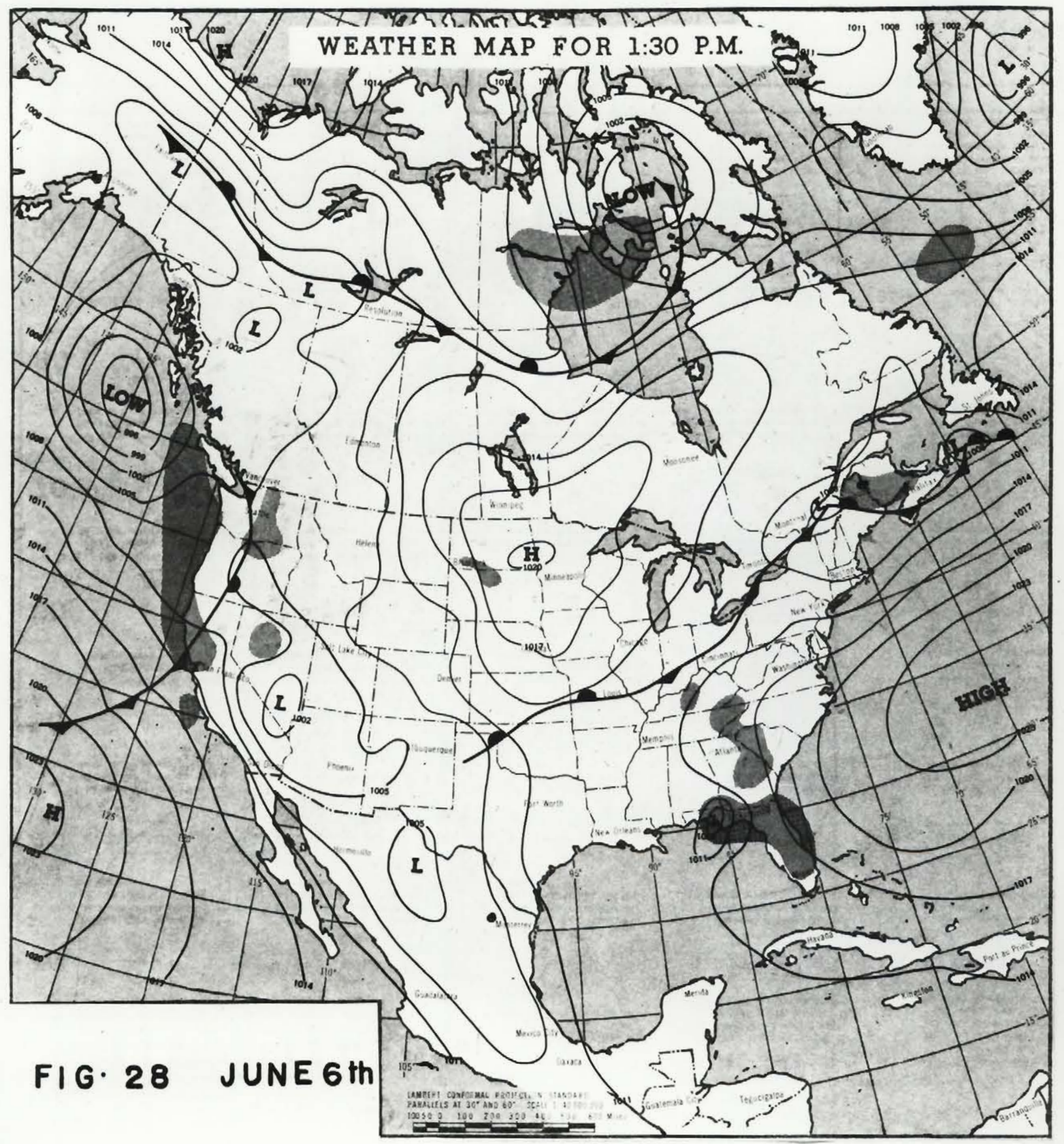




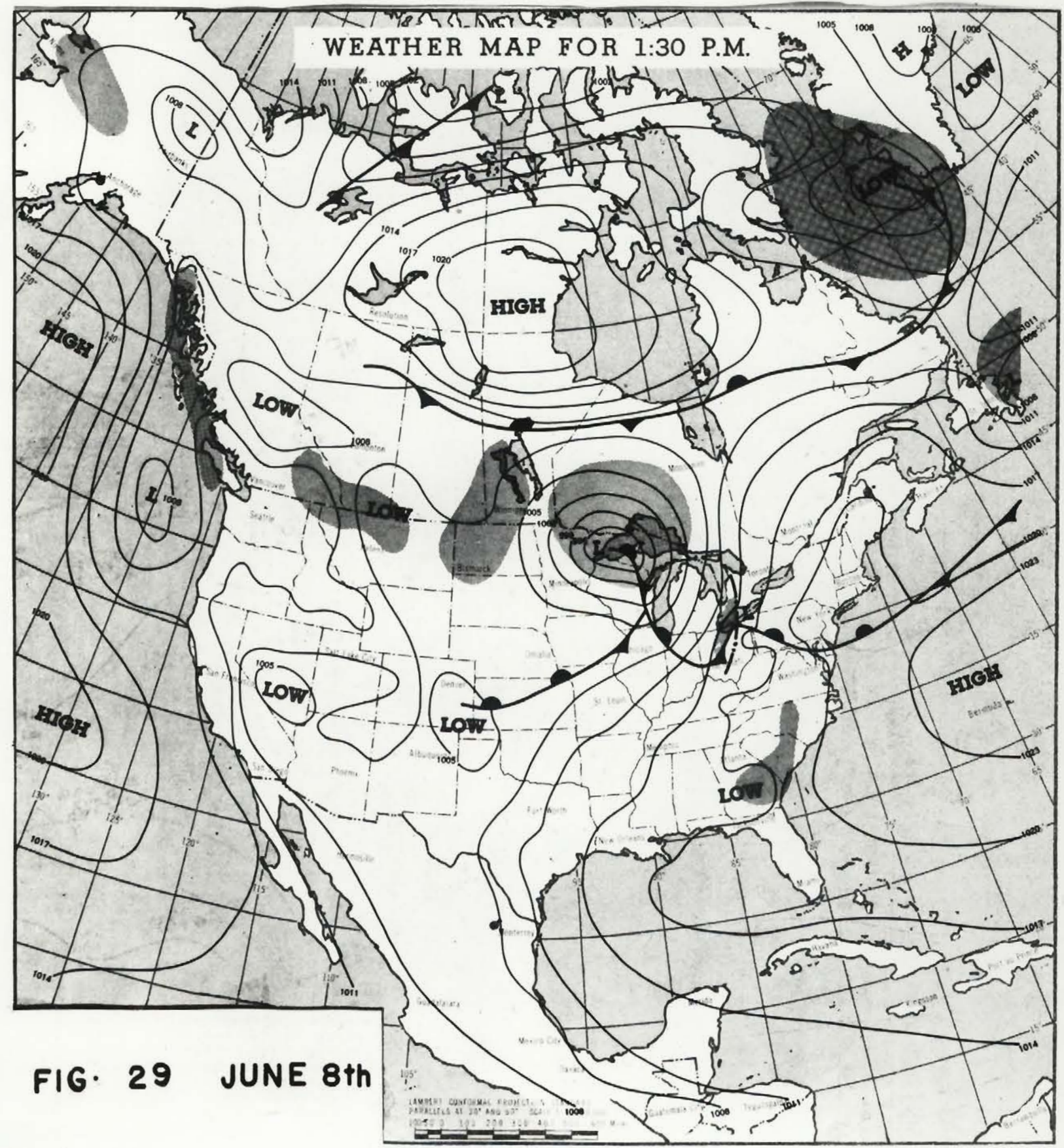




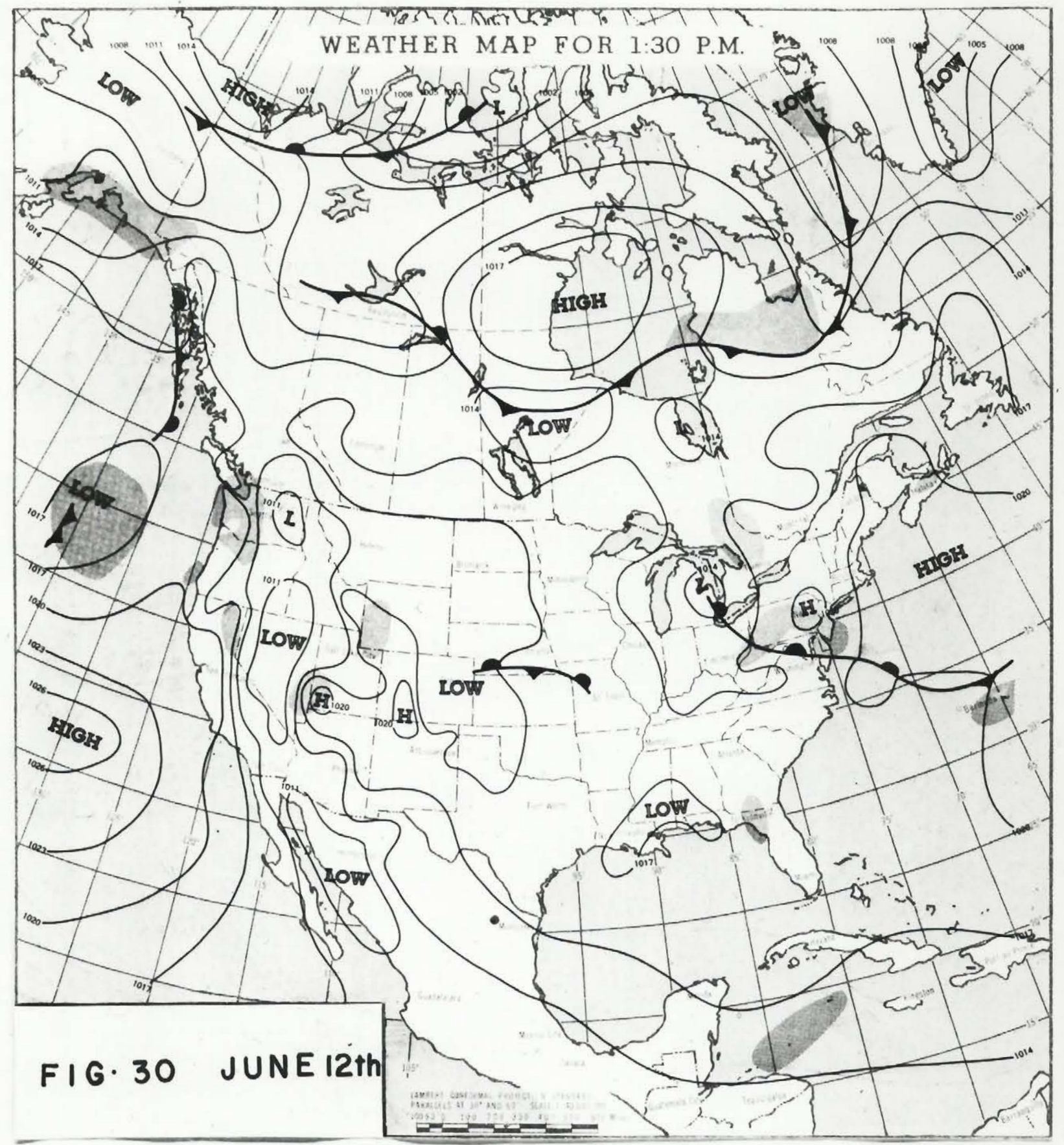




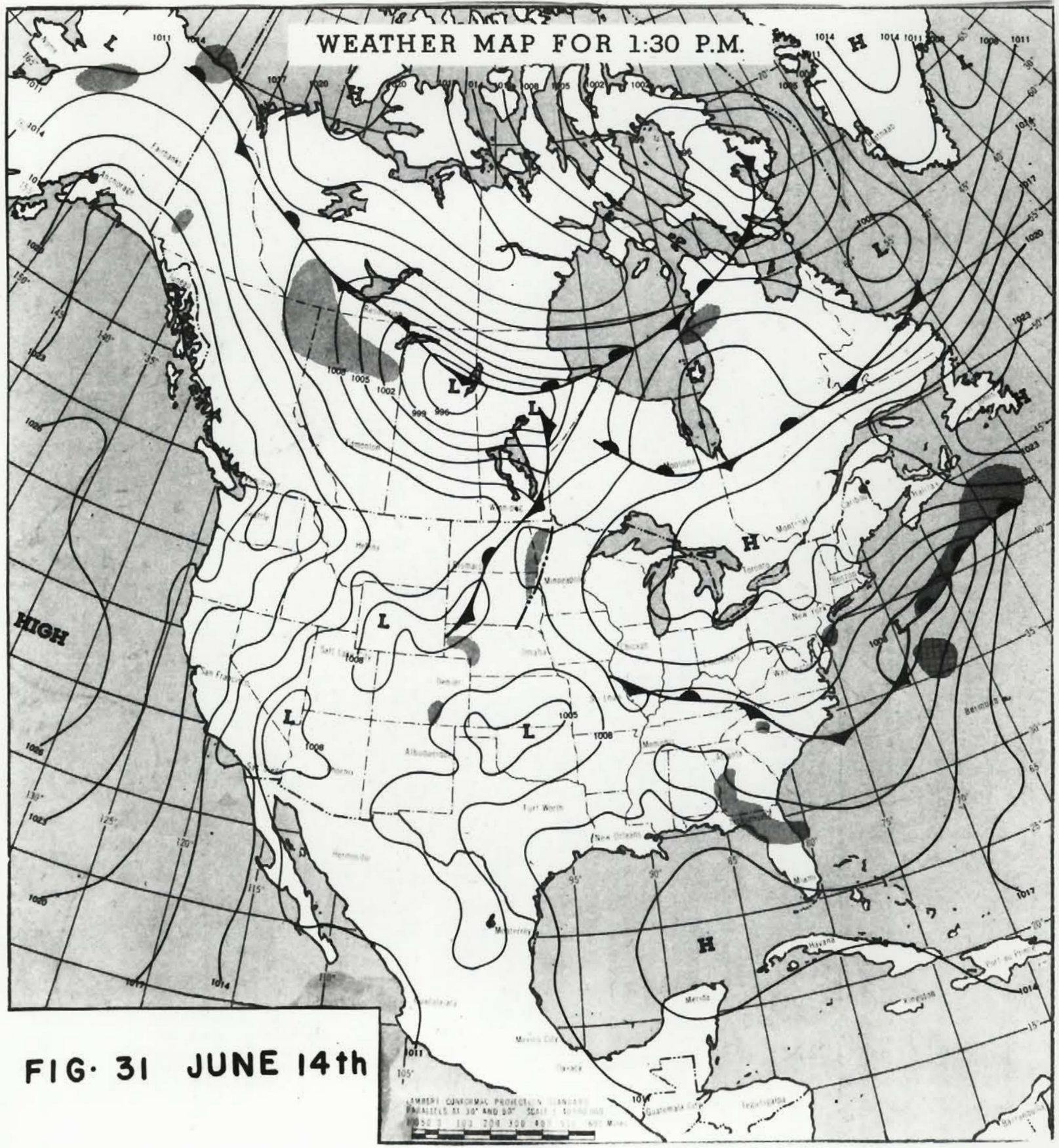




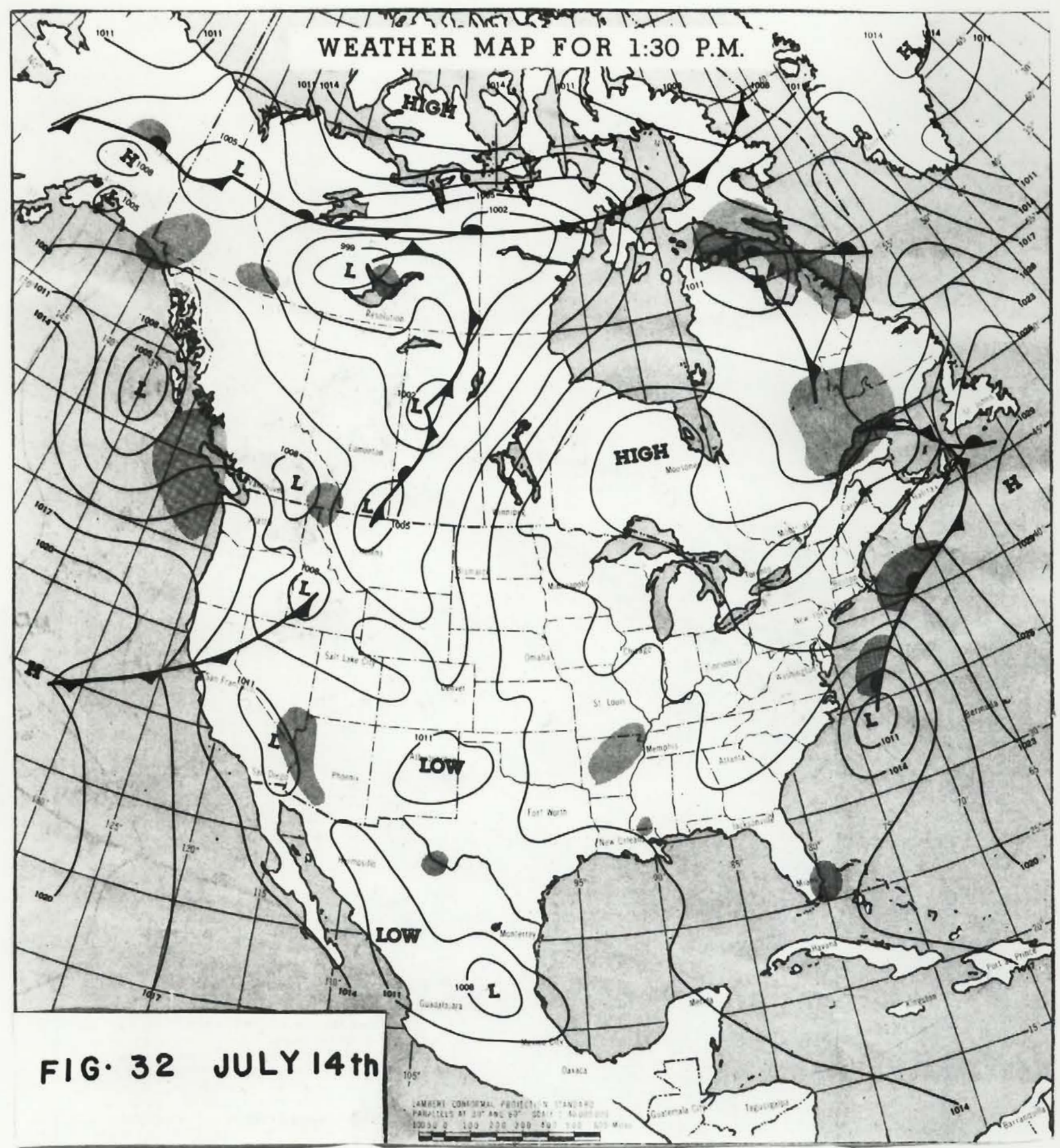




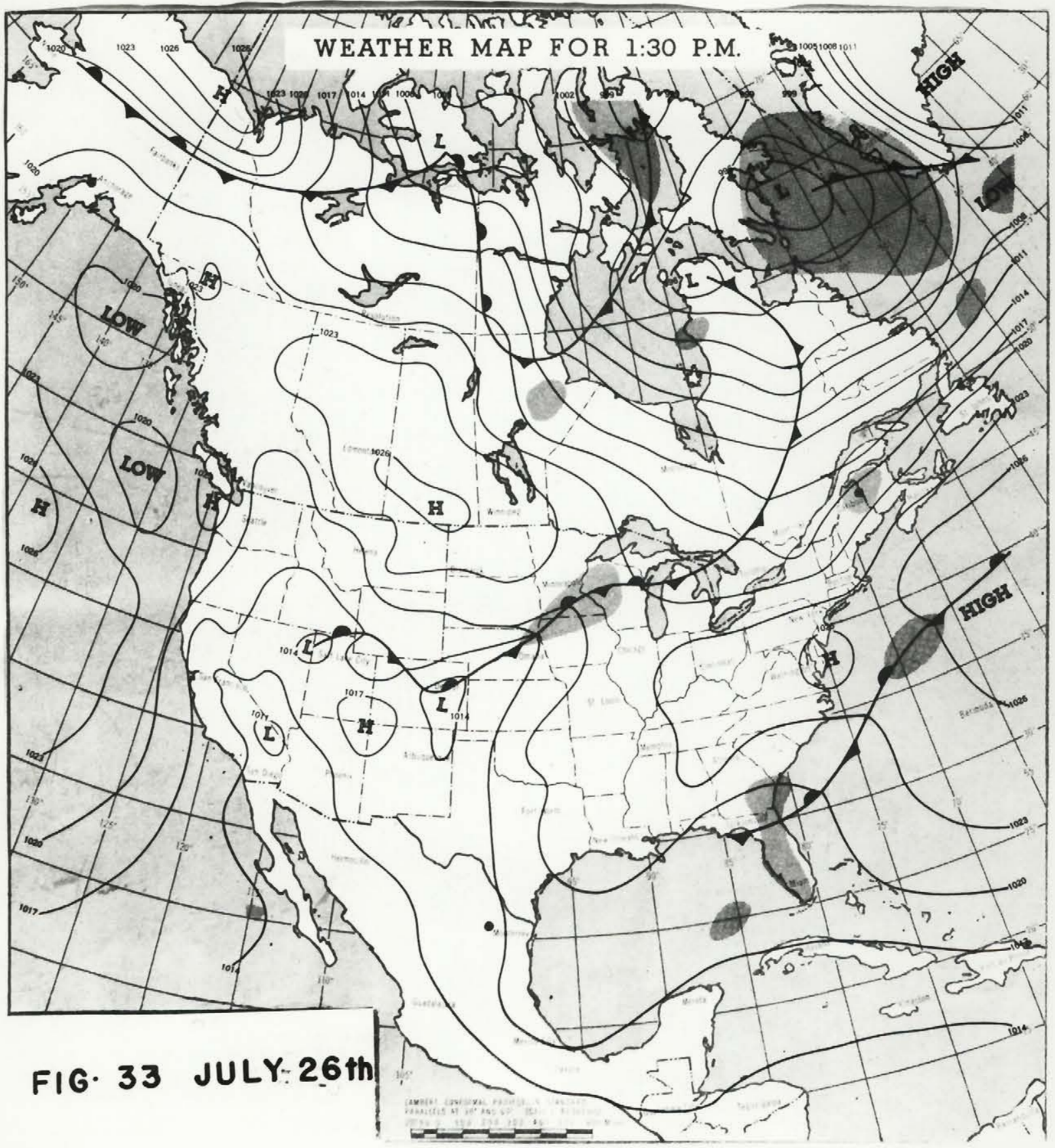


and Yukon southeastwards to Hudson Bay, and then northeastwards across Ungava and the southern tip of Baffin Island, towards southwest Greenland. An examination of the weather maps for the summer of 1953 shows several of these systems; a good example is illustrated in Figure 33. The region of the Penny Icecap is frequently influenced by the northern part of the low pressure systems。

\section{CLOUDS, CLOUDINESS AND FOG}

Rae, 47 in discussing the cloud conditions in the Arctic, describes the Cirro and Alto-type clouds associated with the weak storms crossing the islands in the summer, when the polar front is located near the southern boundary of the Archipelago. He states that these clouds are mostly hidden from an observer on the ground by the ever-present low Stratus. On occasion when there is an active cold front associated with one of these storms, instability cloud of thunderstorm proportions may develop along the front. This, however, rarely happens except over the southernmost regions of the Archipelago. The observations of cloud conditions on the Penny Icecap were often hindered by the frequent fog at the station. It was difficult to observe whether the sky was clear or overcast, as a thin layer of high cloud and a layer of fog at the surface would permit a large amount of radiation to reach the surface, and yet the vertical visibility would be only a few yards. It was important to have detailed 
observations of the cloud conditions to be used in studies of radiation income, and also in studies of ablation. When possible, an estimation was made every second hour during the daytime of the number of tenths of the sky covered by clouds. As mentioned above, strong radiation often reached the surface in spite of thin clouds and fog, and this gave rise to a peculiar relation between radiation and cloudiness in such cases. Wallen 48 has pointed out a similar condition on the Karsa Glacier. It was found on the Penny Icecap, as it was on the Barnes, that often numerous cloud forms were observed, especially previous to passages of fronts. The following values for the relative frequency of typical cloud forms demonstrate this fact:
Cloud form: Fog St-forms
Frequency, per cent $\frac{49.0 \quad 21.9}{70.9}$ Cu-forms 0.9 A-forms 7.5 Ci-forms 20.7

The total frequency of fog and St-form clouds is 70.9 per cent. On the Barnes Icecap the corresponding total was 70.1 per cent. There was 6 per cent less A-form clouds on the Penny Icecap, and 4.3 per cent more Ci-forms. The main difference, however, lies in actual fog at the surface. Fog was more than twice as frequent on the Penny Icecap compared with the Barnes Icecap. 49 This was caused by the difference in altitude of the two stations. The cloudiness as observed on the icecap from May 21 st to August 9 th is presented in the following table. The cloudiness

\section{$48 \mathrm{C}$. C.Wallen, "Glacial-Meteorological Investigations} on the Karsa Glacier in Swedish Lappland 1942-1948," Geografiska Annaler, Vol. 30, Ht. 3-4, 1948, p。 524.

49 Orvig, op. cit., p. 206 。 
for a certain day is the average of seven observations on that day。

\section{TABLE 34}

\section{CLOUDCOVER IN TENTHS OF THE SKY COVERED}

Number of days

\begin{tabular}{lllllllllllr} 
Cloudcover: & 0 & 1 & 2 & 3 & 4 & 5 & 6 & 7 & 8 & 9 & 10 \\
\hline May, 11 days $:$ & & & & 2 & & 1 & & & & 1 & 7 \\
June, 30 days : & 1 & 1 & 2 & 1 & 1 & & 1 & 4 & & 2 & 17 \\
July, 31 days : & & 2 & 1 & 1 & 1 & 1 & 3 & 4 & 18 \\
August, 9 days: & 1 & 1 & 1 & 1 & 2 & & & 1 & 1 & 1 \\
\hline Total period : & 2 & 2 & 5 & 5 & 4 & 2 & 2 & 8 & 0 & 8 & 43
\end{tabular}

A total of forty-three days, or 53 per cent of the time, had completely overcast sky. Some of this time may have had a cloudcover of less than 10/10, but was recorded as completely overcast because of thick fog. The average cloudiness for the whole period was 7.7 , which is exactly the same as the value for the average cloudiness on Isachsen's Plateau, as reported by Sverdrup 50 for the period June 26th to August 15th. There, only 27 per cent of the time had completely overcast sky, however, which is considerably less than the 53 per cent on the Penny Icecap and 46 per cent on the Barnes Icecap.

On the Penny Icecap the cloudiness was practically the same in June and July. An increase from June to July and August, similar to that on the Barnes Icecap, was not experienced. The relation between cloudiness and wind direction on the Penny Icecap is seen in the following compilation.

$50 \mathrm{H} . \mathrm{U}$. Sverdrup, "Results of the Meteorological Obserw vations on Isachsen's Plateau," Geografiska Annaler, Vol. 18, Ht. 1,1936, p. 42 . 
TABLE 35

WIND DIRECTION AND MEAN CLOUDINESS IN TENTHS OF THE SKY COVERED

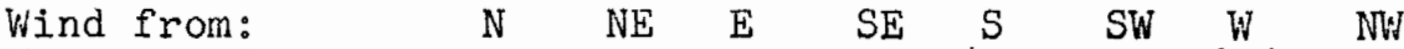
$\begin{array}{lllllllll}\text { Mean cloudiness: } & 7.4 & 7.4 & 7.7 & 9.0 & 8.3 & 7.9 & 6.8 & 4.9\end{array}$

A diurnal variation of the cloudiness was not observed. There was a fairly uniform amount of cloud with most wind directions. The largest difference was between the winds from northwest, usually associated with the clearest weather, and southeast winds, usually associated with overcast weather. F1gure 34 a shows the mean cloudiness with different wind directions for the whole period, May 2lst to August 9th.

Fog. All meteorological reports from icecaps and glaciers stress the high fog frequency. At Station Eismitte on the Greenland Inland Ice fog was observed 15 per cent of the time, and at the Weststation fog was observed 22 per cent of the time。 51 The average probability of fog on Isachsen's Plateau was 0.40 , for the period June 26 th to August $15 \mathrm{th} .52$ On the Barnes Icecap the average probability of fog for the period June lst to August 26th was 0.30 , and on the Penny Icecap, for the period May 21 st to August 9th: 0.61. The probability of fog was very uniform throughout the period on the Penny Icecap, as seen from the following table.

51 F. Loewe, "Das Kilma des Gröländischen Inlandeises," Handbuch der Kilmatologie, Band II, Teil K, 1935, pp.85-86.

52 Sverdrup, 100. cit. 
FIG 34 CLOUDINESS AND FOG

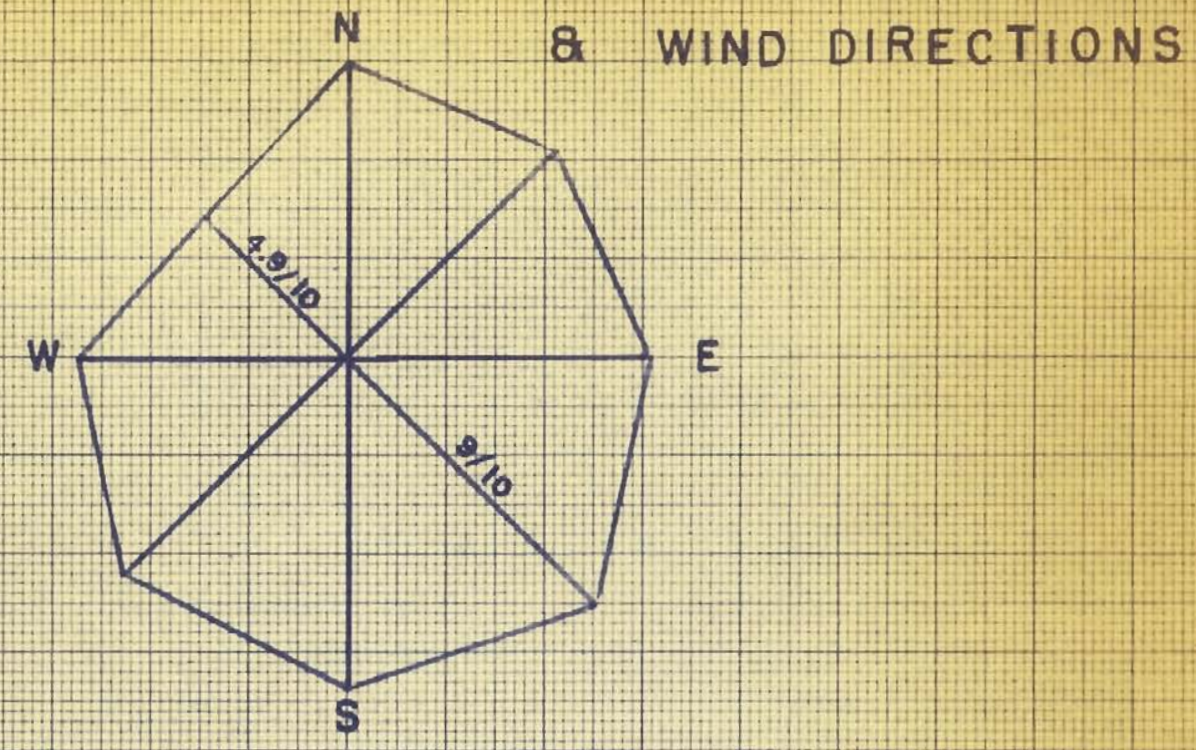

a) MEAN CLOUDINESS

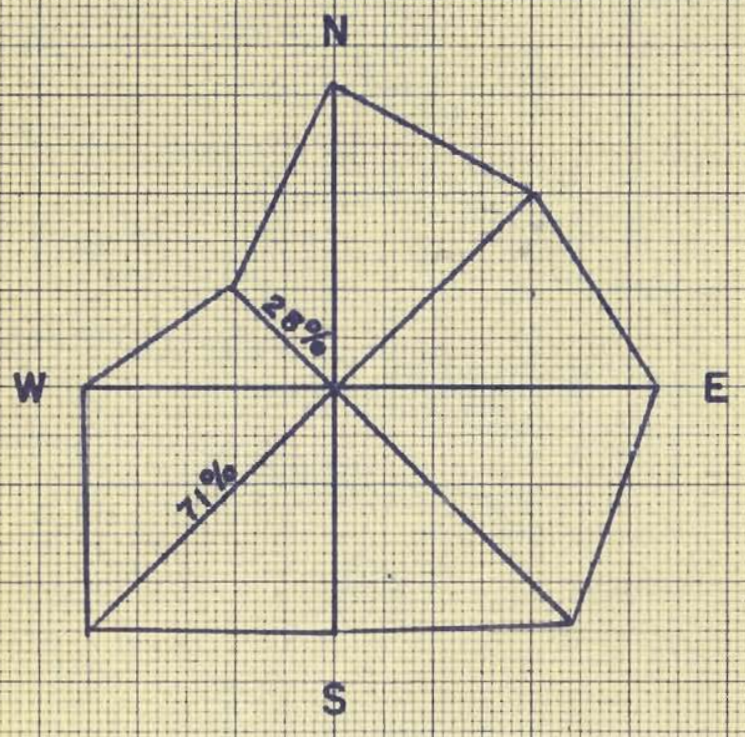

b) PROBABILITY OF FOG 
TABLE 36

PROBABILITY OF FOG

$\begin{array}{lccccc} & \text { May(11days) } & \text { June } & \text { July } & \text { August(9days) } & \text { Period(81days) } \\ \text { Hours of fog: } & 174 & 467 & 473 & 69 & 1183 \\ \text { Probability: } & 0.66 & 0.65 & 0.64 & 0.32 & 0.61\end{array}$

Only the first nine days of August had comparatively little fog. This was a period of good weather, which did not necessarily continue through the whole month. On the Barnes Icecap the month of August had the maximum amount of fog, 54 per cent of the time. Also, the probability of fog increased from 0.18 in June to 0.22 in July and 0.54 in August. As seen above no such seasonal increase took place on the Penny Icecap. The very high probability of fog was constant, and the icecap was free from fog only about one third of the time. Fog was prevalent with wind from all directions, but least so with northwest wind, which also brought the least clouds (Table 35, p。112)。The northwest wind brought the air along the axis of the peninsula, far from open water. This air was much drier than the air from other directions. Fog was very frequent with a southwesterly wind; this is seen in the following table, which shows the probability of fog with different wind directions.

TABLE 37

PROBABILITY OF FOG WITH DIFFERENT WIND DIRECTIONS

Wind from : $N \quad \mathrm{NE} \quad \mathrm{E} \quad \mathrm{SE} \quad \mathrm{S} \quad \mathrm{SW} \quad \mathrm{W} \quad \mathrm{NW}$ Calm

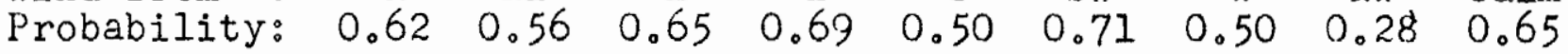

The relationship between wind direction and fog is set forth in Figure 34b。 
There was no particularly marked diurnal variation in fog formation. There was a tendency for the fog to form between 1200 and 1800, and a slight tendency for fog to dissolve during the same six-hour period (often having lasted for several days at the station).

\section{VI。 PRECIPITATION}

As always on glaciers and icecaps, the measurements of precipitation on the Baffin Island icecaps were made difficult by drifting snow and deposition of hoar-frost. Particularly was it almost impossible to measure accurately the precipitation in solid form on a glacier open to the winds. A source of precipitation, which may be of importance at times, is deposition of hoar-frost. Sverdrup 53 states that hoar-frost added approximately 15 per cent to the total precipitation measured during the drift of the "Maud". Ra $e^{54}$ considers this estimate too high, judging from snow depth measurements made at Resolute from 1947 to 1949. Although hoar-frost was common, no increase in depth of snow cover due to hoar-frost accretion was apparent. This was also experienced on the Penny Icecap. Frequently several inches of feathery or solid hoar-frost formed on all upright objects and ropes, some of it dropping off the snow gauges and making uncertain the measurements of snow accumulation. Figure 35 shows

53 H. U. Sverdrup, "Ubersicht über das Klima des Polarmeeres und des Kanadischen Archipels," Handbuch der Kiimatologie, Band II, Teil K, 1935, p。22。

$54 \mathrm{R}$. W。 Rae, Climate of the Canadian Arctic Archipelago. Toronto: Department of Transport, 1951, p. 17. 
$-116-$

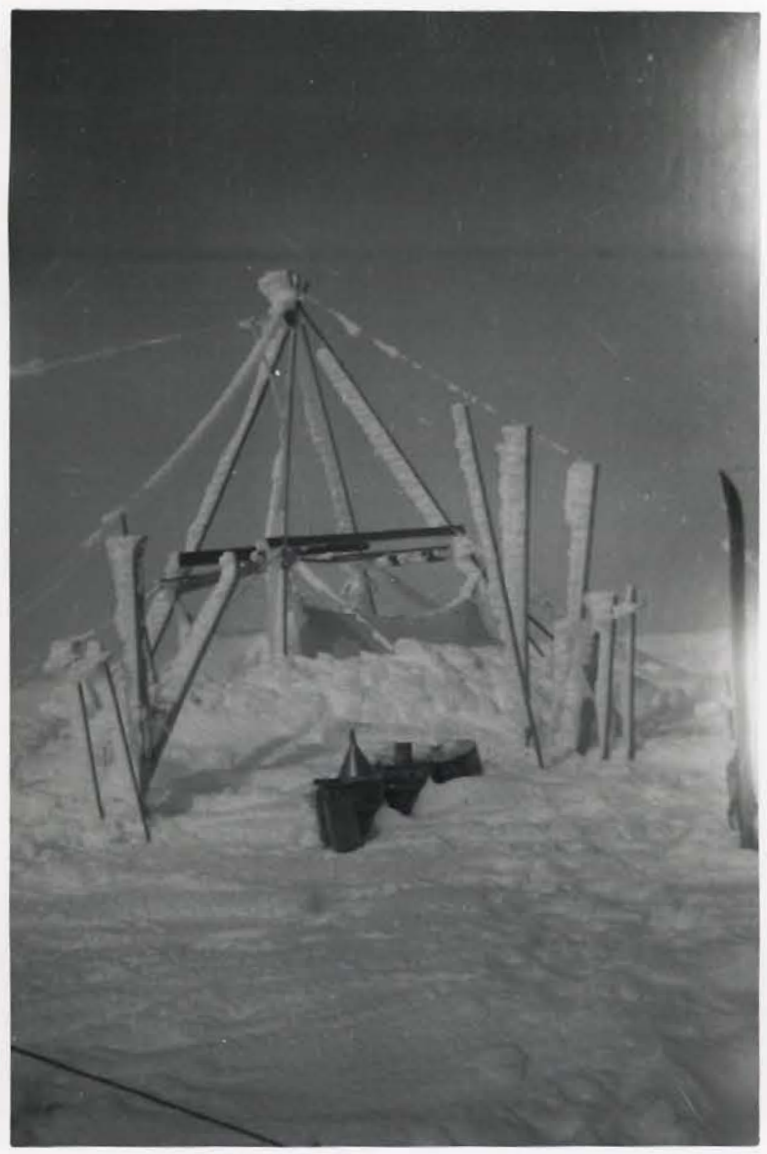

Fig. 35. Hoar-frost. 
hoar-frost on the southwest side of obstacles at the camp. Anticyclonic precipitation (snow or sublimitation crystals) were not experienced on either of the Baffin Island icecaps. Loewe 55 points out that this type of precipitation only rarely was observed on the Greenland Inland Ice by the Wegener Expedition, and the British Greenland Icecap station of the same year did not observe any occurrences of precipitation of this kind. Several observers have noted formation of hoar-frost on the surface in Greenland, but calculations of the maximum possible amount give the result that not more than one tenth of the total accumulation is due to hoar-frost. 56 As mentioned previously, the amount of hoar-frost forming on the surface of the Penny Icecap at 6725 feet was negligible, although on vertical objects the accretion was considerable.

In this study the standard procedure of the Meteorological Service of Canada is used when total precipitation is discussed. This consists of converting the amount of snow to equivalent rain on the assumption that ten inches of snow correspond to one inch of rain in water content. In the Arctic this is not always the case, and in the studies of ablation the water equivalent is used as calculated from the measurements of the density of the snow.

55 Loewe, op. cit., p. 90 .

56 Ibid., p.91. 
TABLE 38

MONTHLY PRECIPITATION IN INCHES

\begin{tabular}{lcr} 
& Rain & Snow \\
\hline May (11 days): & - & 2.88 \\
June: & - & 13.38 \\
July: & 0.88 & 16.00 \\
August $(9$ days): & - & 0.38 \\
\hline Total: & 0.88 & 32.64
\end{tabular}

The probability of occurrence is given in the following table (the number of observations when rain, drizzle, snow and hoar-frost was observed, divided by the total number of observam tions)。

TABLE 39

PROBABILITY OF RAIN, DRIZZLE, SNOW, AND HOAR-FROST

\begin{tabular}{lcccc} 
& Rain & Drizzle & Snow & Hoar-frost \\
\hline May (1l days): & - & - & 0.28 & 0.09 \\
June: & - & 0.01 & 0.21 & 0.11 \\
July: & 0.05 & 0.01 & 0.15 & 0.06 \\
August (9 days): & $\infty$ & - & 0.08 & 0.03
\end{tabular}

The probability of drizzle was very small, also in fog。 On the Barnes Icecap it was found that drizzle was especially frequent in June and July when fog was present. 57 On the Penny Icecap the temperatures were much lower, and drizzle was rarely experienced. Most of the precipitation fell as snow. Snow was more frequent on the Penny Icecap than on the Barnes in both June and July, and during the two months the Penny Icecap received 29.38 inches, while in 1950 the Barnes Icecap received 28.33 inches.

57 S. Orvig, "The Clinate of the Ablation Period on the Barnes Ice-Cap in 1950," Geografiska Annaler, Vol。33, Ht。3-4, 1951, p. 208. 
CHAPTER IV

\section{RADIATION MEASUREMENTS ON THE PENNY ICECAP}

In a study of the meteorological factors which control the ablation on a glacier or icecap, it is usually relatively easy to obtain reliable obscrvations of the standard meteorological elements. The instruments needed for observations of temperature, humidity, pressure, wind and precipitation are easily transported and set up at a glacier station. It is more difficult to transport the heavy and fragile instruments needed for radiation observations, and reliable radiation data from arctic glaciers and icecaps are few. The 1950 Baffin Island Expedition had only a Campbell-Stokes sunshine recorder for measurements of duration of sunshine. No other radiation instrum ments were available at that time. The 1953 Expedition was better equipped, and the present chapter deals with the radiation studies carried out on the Penny Icecap.

\section{I。 DURATION OF SUNSHINE}

A Campbell-Stokes recorder was used on both icecaps to record the hours of sunshine. The duration of sunshine was never influenced by topography, as both stations were situated on wide, plane snow surfaces with a practically unobstructed horizon. Table XI gives the duration of sunshine in fractions of an hour for each day, and the total hours of sunshine from midnight May 20th. 
The Campbell-Stokes recorder did not record the sunshine when the sun was relatively low on the northern horizon, as the frame of the instrument then shielded the recording paper. The figures in Table XI are actual hours of sunshine, the amount of "night-sunshine" (after 2000 hours and before 0400 hours) has been added when such sunshine was observed.

The icecap station was located approximately twenty-five miles north of the Arctic Circle, in latitude $660^{\circ} 58^{\prime} 30^{\mathrm{N}} \mathrm{N}$. Midnight sun theoretically lasts, at this latitude, as long as the sun's declination is equal to or larger than $23^{\circ} 01130^{\prime \prime}$. Considering the refraction, which at the horizon may be taken as $35^{\prime}$, and allowing for the semi-diameter of the sun, which is 16', the upper limb of the sun will be on or above the horizon on the days with declination equal to or larger than $23^{\circ} 01^{\prime} 30^{\prime \prime}-51^{\prime}=22^{\circ} 10^{\prime} 30^{\prime \prime}$. From the 1953 Almanac it is seen that this took place from June 3rd to July llth, inclusive. I The value of refraction may sometimes be higher in the Arctic; $01 s^{2}{ }^{2}$ used $35^{\prime}$ in his calculations from Spitsbergen, although the refraction sometimes amounted to $58^{\prime}$.

To calculate the hours of sunshine to be added for clear "nights" to the hours recorded by the Campbell-Stokes recorder, use has been made of the sunrise-sunset nornogram supplied with

1 The American Ephemeris and Nautical Almanac for the Year 1953. Washington: The Nautical Almanac Office, United States Naval Observatory, 1951, pp. 8-10.

2 H. Olsson, "Sunshine and Radiation, Mount Nordenskiöld, Spitsbergen," Geografiska Annaler, Vol. 18, Ht. 1, 1936, p. 95. 
TABLE 40

RECORDED HOURS OF SUNSHINE AS PERCENTAGE OF POSSIBLE SUNSHINE

\begin{tabular}{lcccc} 
& Recorded Sunshine & Possible Sunshine & Per Cent \\
\hline May (1l days) & $\vdots$ & 57.7 & 233.6 & 24.7 \\
June & $\vdots$ & 175.4 & 718.1 & 24.4 \\
July & $\vdots$ & 150.7 & 679.0 & 22.2 \\
August (9 days) & $\vdots$ & 83.3 & 166.3 & 50.1 \\
\hline Total & $\vdots$ & 467.1 & 1797.0 & 26.0 \\
\hline Period May 21-June 2: & 67.0 & 279.7 & 24.0 \\
" June 3-July 11: 253.5 & 936.0 & 27.1 \\
" July 12-Aug. 9: 146.6 & 581.3 & 25.2
\end{tabular}

The recorded hours of sunshine for the whole period were only 26 per cent of the possible. The recorded sunshine was a very constant percentage of the possible for most of the summer, except for the first nine days of August, when 50.1 per cent was recorded. This investigation was also carried out by splitting the period of observation into three parts, the middle of these being the period from June 3rd to July llth, with the upper limb of the sun continuously above the horizon. The percentage of sunshine was 27.I in this period, due to the six days in late June and three days in early July with clear weather.

Considerably more sunshine than this was recorded on the Greenland Inland Ice by Wegener's Expedition. The percentages of possible sunshine for June and July at Station Eismitte were 65 and 42 respectively, and then allowance was not made for sunshine when the sun was near the horizon. A calculation of the percentage of possible sunshine between 1100 and 1300 hours gave the result that in June 82 per cent was recorded and in July 58 per cent was recorded. 4 Handbuch der Klimatologie, Band II, Teil K, 1935, p. 76. 
During the second International Polar Year, 1932-33, Sweden operated a meteorological observatory on Mount Nordenskionld, Spitsbergen $\left(78^{\circ} 11^{\circ} \mathrm{N}-3442\right.$ feet above sea level). There the recorded sunshine in June and July 1933 was 38.6 and 39.2 per cent of the possible. 5 This is also considerably more than that recorded on the Penny Icecap, where the higher frequency of fog is responsible for the low values. As mentioned previously, days. when Camp Al was situated in thick fog have been recorded as overcast. Some days had thick fog, but a certain amount of radiation. There is therefore no close agreement between the observed averages of cloudiness and of duration of sunshine.

Figure 36 shows the duration of sunshine for each day of the summer in 1953. Twenty-five days, or nearly 31 per cent of the time, had no sunshine, and the periods with no sunshine were of one to three days' duration, interrupting periods with sunshine of from one to six days' duration. The longest period with some sunshine on each day lasted from August lst to 9th. Only three periods had an amount of sunshine approaching the maximum possible. Those periods were May 25 th to $27 \mathrm{th}$, June 24 th to $29 \mathrm{th}$, and July 3 rd to 5th. A comparison of Figure 9 (mean daily temperature) and 36 shows that the mean daily temperature did not follow the sunshine graph at all closely. A number of days with very little sunshine had higher temperatures than days with many hours of sunshine. Some examples are the following: June 4 th had no sunshine, but the mean temperature was 11.5 degrees higher than on June 3 rd,

5 0lsson, op. cit., p. 98 


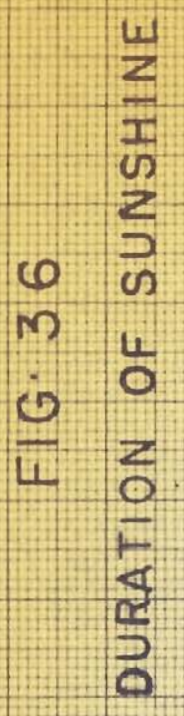
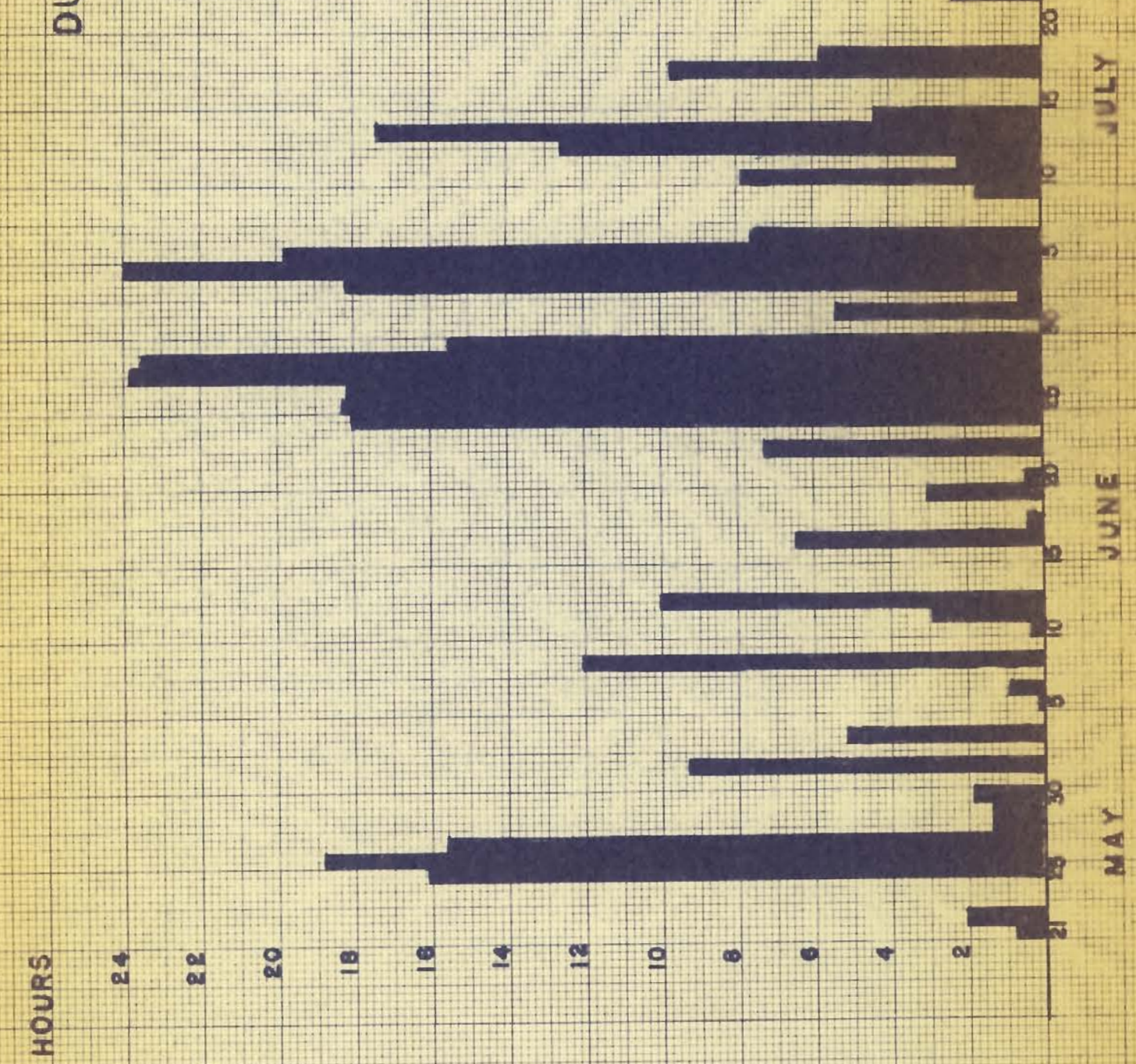
with almost five hours of sunshine; June 5 th had less than ten minutes of sunshine, but the mean temperature was the highest for the thirty days from May 26th to June 24th; June 13th had no sunshine, but the mean temperature was 12.1 degrees higher than on June 12th, with ten hours of sunshine; June 29th had 15.5 hours of sunshine, and a mean temperature of $23.5^{\circ}$, while June 30 th had no sunshine and a mean temperature of $25.2^{\circ}$; July 24 th and 25 th had the highest mean daily temperature of the summer, but the total hours of sunshine for the two days only amounted to 2.6 hours. The same phenomenon was observed on the Barnes Icecap, and the reason for this apparent anomaly is the marked lowering of the mean daily temperature by the strong outgoing radiation on clear nights, in spite of a certain amount of "night sunshine". This sunshine was weak and not able to counteract the cooling by long-wave radiation, except to some extent in the evening and early morning.

A similar comparison of Figures 17 (mean daytime temperatures) and 36 shows that neither did the mean daytime temperature follow the sunshine graph at all closely. This was rather unexpected, as night temperatures are not considered in this case. The sunshine, even on days when it was strong and almost continum ous, was not able to heat the air over the icecap to any great extent, the underlying surface always being at or below the freezing point.

6 S. Orvig, "The Clinate of the Ablation Period on the Barnes Ice-Cap in 1950," Geografiska Annaler, Vol. 33, Ht. 3-4, $1951, p .208$. 
As indicated here and discussed previously $(\mathrm{pp}, 67 \times 70)$ the icecaps act as temperature stabilizers. On clear days the temperature will remain relatively low, on clear nights the longwave radiation will cool the air. On overcast days the heating of the air during the daytime is less, but the cooling at night is also less, the result being a smaller diurnal variation of temperature. The heating of the air on sunny days takes place over the snow free land surrounding the icecaps. The temperatures over the ice itself are dependent on the duration of sunshine and on the distance the air has travelled over the icecap surface.

\section{TOTAL RADIATION FROM SUN AND SKY}

Instruments. The standard instrument used in Canada for radiation measurements is the Eppley pyrheliometer. As this instrument is expensive and delicate a subsidiary actinograph has been developed, which is self-contained and operates without external power. 7 This new actinograph is being utilized to augment the Eppley network. The instrument is used for measuring total solar and sky radiation received on a horizontal surface. It is designed primarily to give total radiation for the day. Because of the lag of the instrument, its instantaneous readings have, in practice, limited application. The total radiation as shown by the three-day graph is too low, and it must be multiplied by a factor (1.06) to obtain the correct daily total. The total

7 Instructions for the Operation of the M.S.C. Type G Bimetal Actinograph. Toronto: Department of Transport, Manual 80, 1952, p. 1. 
incoming radiation from sun and sky for the day is expressed in gram calories per square centimeter.

Because actinographs had been used previously in glaciological investigations -- for instance, by Ablmann in Spitsbergen 1931, by Olsson in Spitsbergen 1934, by Etienne in Greenland 1938, and by Wallen on the Karsa Ciacier ${ }^{8}$-- and also because few radiation data exist from the Canadian Arctic, the Controller of the Meteorological Division, Department of Transport, Mr.A. Thomson, kindly permitted the Baffin Island Expedition 1953 the loan of one of the new actinographs. The instrument was standardized at Toronto in April before being shipped to Montreal, but when it was unpacked on the Penny Icecap on May 20th it was found that the metal ligament between the black bimetal and the pen arm was broken. The instrument was dismantled to repair the ligament. W. Ho Ward carried out the repairs, and after it had been reassembled the zero was reset with the glass dome covered. This work was done in the living tent and the midnight readings on subsequent days were somewhat above the tent zero. The actinograph was erected in the afternoon of May 20th, the bimetals four feet above the snow surface. It was found that the instrument had to be rezeroed after sunset in the early period when the sun sank below the horizon at night. This zero adjustment was carried out every third evening when changing the chart, after first covering the glass dome of the instrument for one hour. A check of the zero the Karsa Glacier in Swedish Lappland 1942-1948," Geografiska Annaler, Vol。30, Ht。3-4, 1948, p. 477. 
was made at chart changing time throughout the period, corrections being applied when necessary. The total incoming radiation was recorded for every day from May 2lst to August 8th, inclusive, with the exception of May 30th and 31st, when the clock stopped, and the three day period June 27 th-29th as that chart was torn from the observer's hand in the strong wind at the time of changing charts. On July 13 th and July 22nd the clock stopped in the morning, causing incomplete records for those two days. Complete records were thus obtained for seventy three days.

It was frequently found that hoar-frost formed on the outside of the glass dome, but in these cases care was taken in wiping the glass as often as possible, and no important interruptions in the records were caused by hoar-frost. This was only possible, however, because the observers were present continuously in the immediate vicinity of the instrument. No moisture condensed on the inside of the glass dome, as the instrument was fitted with a drier cartridge of silica-gel. This was most important in locations such as that of Camp Al.

On evacuating the icecap station the instruments and the most valuable equipment together with records and personal gear had to be hauled on sledges down Coronation Glacier to sea level, a trip of some twenty-eight miles with a drop of 6725 feet. Somewhere between the Penny Icecap and Montreal, either on the sledge trip or on aircraft or ship, the glass dome of the actinograph was broken. As the calibration of the instrument is a function of the particular glass dome used, it is doubtful if a recalibration with a new glass could necessarily be related to the previous calibra- 
tion. The values obtained during the summer of 1953 will therefore be set forth in the following without the check that a recalibration would afford.

It has been considered that actinographs of a similar type (Robitzsch Actinograph) give results with a mean error in the daily radiation income of, in general, 3-4 per cent, 9 but Angstrom ${ }^{10}$ states that the accuracy is dependent on temperature, and it is difficult to avoid errors of less than about 10 per cent for individual days and less than 5 per cent in monthly means. The new MoS.C. Type G Bimetal Actinograph, however; is not affected by changes in ambient temperature, and the errors should be less than those quoted by Angström.

Figure 37 shows the above-mentioned instrument, which was placed with the window facing north and the bimetal strips in a north-south direction. The values obtained from this actinograph can be compared with those recorded simultaneously on a second actinograph, situated twenty feet away, with the window facing north and the bimetal strips in an east-west direction, three feet above the surface. Figure 38 shows this actinograph, which was a new Kew Type Robitzsch Bimetal Actinograph, brought from England by W.H.Ward. This instrument had a one-day chart, and the record of daily incoming short-wave radiation is complete for every day from May 21st to August 8th, with the exception of May 30th, June

7 Wo Morikofer and C. Thams, "Erfahrungen mit dem Bimetall aktinographen Fuess-Robitzsch," Meteorologische Zeitschrift, Bd。 54,1937, po 371 .

10 A. Angstrom, "Actinometric Measurements," Compendium of Meteorology, American Meteorological Society, Boston, 1951, pp。 $54-55$. 


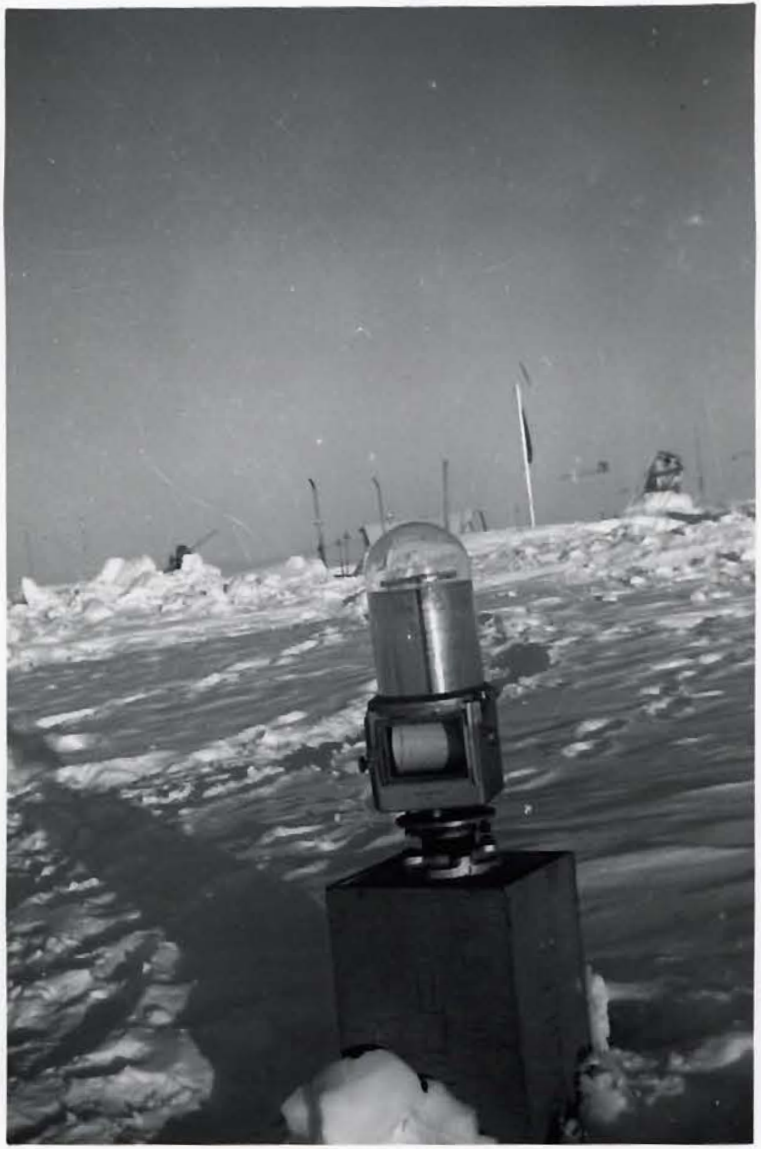

$$
\begin{aligned}
& \text { Fig. 37. M.S.C. Type G Bimetal } \\
& \text { Actinograph. }
\end{aligned}
$$




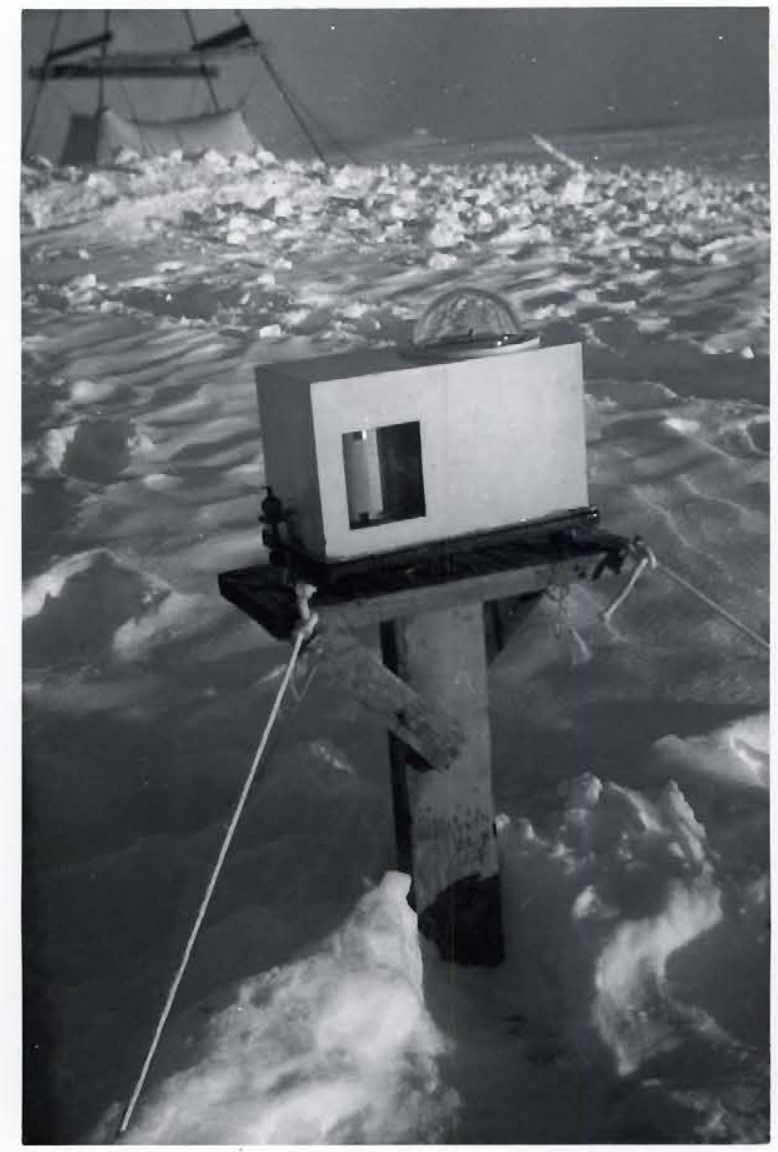

Fig. 38. Kew Type Robitzsch Actinograph. 
Ist and short periods on a few occasions when difficulties were experienced due to formation of hoar-frost on the glass dome and also a few cases of clock stoppage.

Results. It was found that the two actinographs gave slightly different values for the incoming radiation. The Canadian instrument gave consistently higher values, and the ratio between the 24 -hour radiation as recorded by the Kew Type and by the M。S.C. Type $G$ actinographs varied between 0.96 and 0.71 . The average of thirty comparisons gave the ratio: $\frac{\text { Kew Type }}{\text { MSC Type }}=0.81$. The spread is not great, and it is to be assumed that the average of the daily values from the two instruments will give an accurate value for the daily incoming radiation. Those values are set forth for each day in Table XII. For some days the recordings on the Kew Type actinograph have not been evaluated, and for those days the average values have been calculated according to: $\frac{\text { Kew }+ \text { Type } G}{2}=\frac{(0.81 \times \text { Type } G)+\text { Type } G}{2}=0.9 \times$ Type $G$ 。 On a few days when only the Kew values are available, the average values have been calculated according to: $\frac{\text { Kew }+ \text { Type } G}{2}=$ $\frac{\frac{K e w}{0.8 I}+K e w}{2}=\frac{K e w\left(1+\frac{1}{0.8 I}\right)}{2}=1.1 \times \mathrm{Kew}$. It is of interest to compare the values obtained on the Penny Icecap with other radiation measurements in high latitudes. The periods of investigation are always short, however, and it is therefore best, as Wallen ${ }^{11}$ has pointed out, to compare the mean values of radiation for clear and

$$
\text { II WaIIen, op. cit., p. } 486 .
$$


overcast sky.

The Karsa Glacier is located at about $68^{\circ} 20^{\circ} \mathrm{N}$, while station AI on the Penny Icecap was at about $67^{\circ} \mathrm{N}$. The radiation figures may therefore be compared for the same periods. Wallen has studied the incoming radiation with clear sky $\left(I_{0}\right)$ and the incoming radiation with overcast sky $\left(I_{10}\right)$ for different periods. In order to compare these results with those from the Penny Icecap, the same periods have been chosen, and for the Karsa Glacier these are: Period 1: 20/5-10/6; Period 2: 20/6-10/7; and Period 3: 20/7 = 15/8. The similar periods for the Penny Icecap are: Period 1: 21/5-10/6; Period 2: 20/6-10/7; and Period 3:20/7-8/8. The radiation for the different periods on the Penny Icecap, and the ratio $I_{10} / I_{0}$, is set forth in the following table, where the last column gives the ratio $I_{10} / I_{0}$ for the same periods on the Karsa Glacier.

TABLE 41

INCONING RADIATION AND THE RATIO $I_{10} / I_{0}$

\begin{tabular}{llllll} 
Period & $I_{10}$ & $I_{0}$ & $I_{10} / I_{0}$ & $I_{10} / I_{0}$ (Karsa Glacier) \\
\hline 1 & 635 & 809 & 0.78 & 0.50 \\
3 & 657 & 807 & 0.81 & 0.46 \\
& 452 & 608 & 0.74 & 0.43
\end{tabular}

The values of the ratio $I_{10} / I_{0}$ are considerably higher on the Penny Icecap than on the Karsa Glacier. The explanation is the frequent thick fog on the Penny Icecap, when the sky was reported overcast, in spite of the fact that there may have been no middle and high clouds. The fog probably permitted more radiation to reach the surface than 10/10 middle and high cloud would have 
done, but under the circurnstances no better values for $I_{10}$ are available。

The high values of incoming radiation are reasonable when compared with those obtained by 0 sson $^{12}$ in West Spitsbergen, at $79^{\circ} \mathrm{N}$. During the last week of June he recorded a daily value of up to $840 \mathrm{cal} / \mathrm{cm}^{2}$, and around August lst up to $680 \mathrm{cal} / \mathrm{cm}^{2}$.day。 This is only 37 and $1 \mathrm{cal} / \mathrm{cm}^{2}$.day, respectively, different from the Penny Icecap values. Mosby ${ }^{13}$ measured $800 \mathrm{cal} / \mathrm{cm}^{2}$ at clear sky in late May over the pack ice; on May 25th on the Penny Icecap the total radiation was $845 \mathrm{cal} / \mathrm{cm}^{2}$. That day was clear until 1600, thereafter 4/10 cirro-stratus. At Sveanor in Spitsbergen $\left(79^{\circ} 56 \cdot \mathrm{N}\right) 772 \mathrm{cal} / \mathrm{cm}^{2}$.day was recorded with clear sky in the middle of July, ${ }^{14}$ and with overcast sky around $220 \mathrm{cal} / \mathrm{cm}^{2}$ was recorded。 The corresponding values on the Penny Icecap were 767 and 384 $\mathrm{cal} / \mathrm{cm}^{2}$.day, An increase in elevation will give higher radiation income, and none of the investigations referred to above were undertaken at an altitude comparable to that of the Penny Icecap. The values obtained at this location are therefore in remarkably good agreement with previous investigations。

The ratio $I_{10} / I_{0}$ and its variation with time is of great

$12 \mathrm{H} \cdot \mathrm{O}$ lsson, "Radiation Measurements on Isachsen's Plateau," Geografiska Annaler, Vol.18, Ht.3-4, 1936, p. 231.

13 H. Mosby, "Sunshine and Radiation," The Norwegian North Polar Expedition with the "Maud" 1918-25. Scientific Results, Vol. Ia, No. 7, 1933.

14 A. Angstro"m, "On the total Radiation from Sun and Sky at Sveanor," Geografiska Annaler, Vol.15, Ht。2-3, 1933, p. 157 . 
interest in radiation studies. Wallen ${ }^{15}$ has plotted the annual variation of $I_{10} / I_{0}$ according to different investigations in high latitudes. All curves from the Arctic, and northern regions generally, show a decrease of the ratios from May to August, and no values are as high as 0.70 . As seen in Table 41 this decrease was not found to be as simpie on the Penny Icecap, where all values were above 0.70. The reason is the impossibility of observing cloud conditions through the thick fog, and it is probable that the high values for $I_{10}$ were partly caused by multiple reflection between the snow surface and the fog. It may also be that the high values of $I_{10} / I_{0}$ on the Penny Icecap are caused by thinner clouds overhead than those experienced in other locations. Certainly the low stratus frequently found in the Arctic in summer would not influence the station at 6725 feet.

Figure 39 shows the graphs of incoming radiation for two three-day periods, as recorded by the M。S.C. Type G actinograph. The three days of June 18th, 19th and 20th had fog of varying thickness, allowing a considerable amount of radiation to reach the surface. However, the type and amount of middle and high cloud could not be observed, except on the morning of June 19th, when 7/10 alto-stratus was observed from 0800 until 1100. The total incoming radiation for the three days as recorded on this instrument amounted to $2264 \mathrm{cal} / \mathrm{cm}^{2}$. The value for the three days as given in Table XII was $2037 \mathrm{cal} / \mathrm{cm}^{2}$.

$$
15 \text { Wallen, op. cit. fig. 15, p. } 491 \text {. }
$$




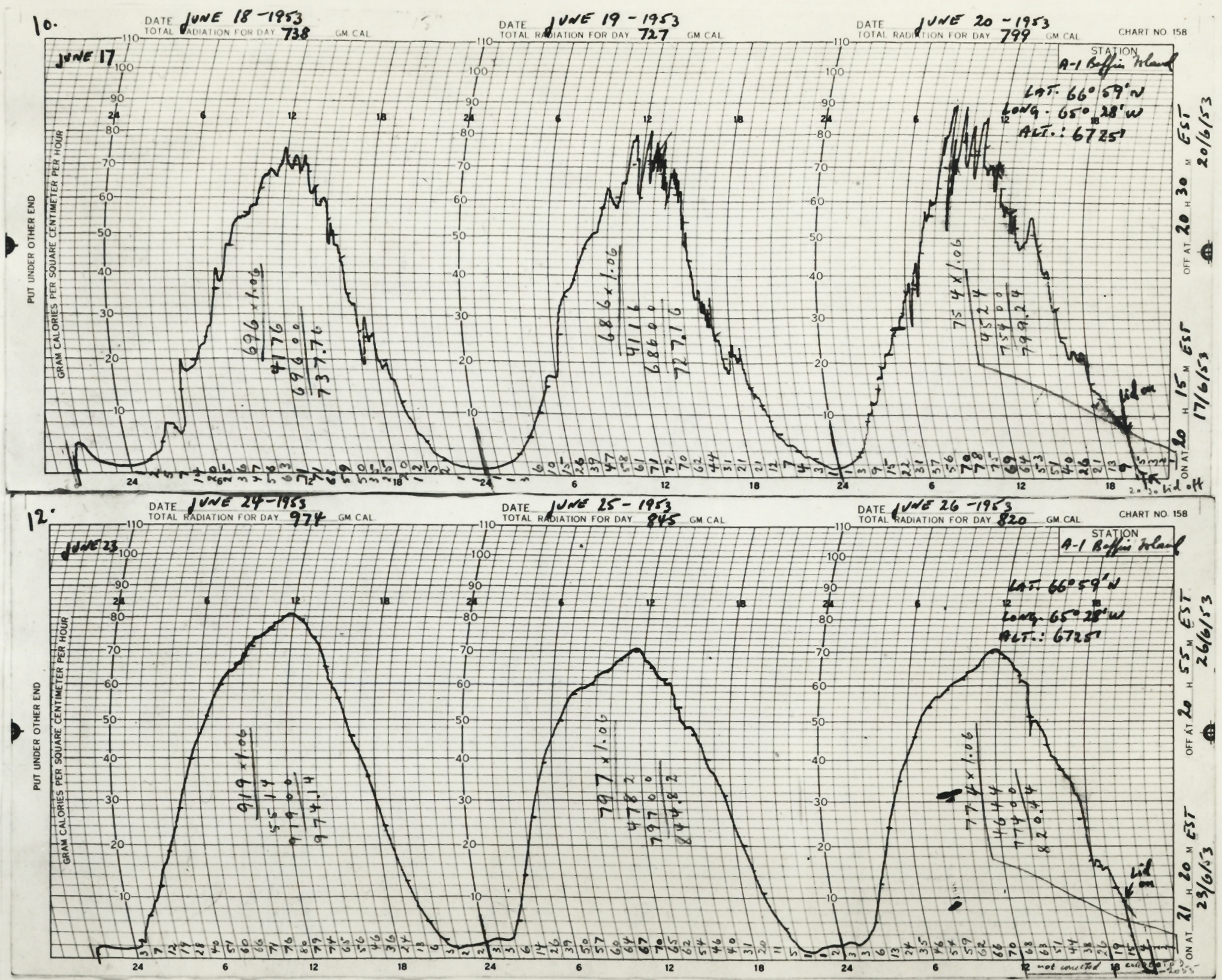

FIG. 39 INCOMING RADIATION ON SIX DAYS 
The tinree days of June $24 \mathrm{th}, 25 \mathrm{th}$ and $26 \mathrm{th}$ had $2 / 10$ cirrus, $1 / 10$ cirrus and 3/10 cirrus, and the total incoming radiation for the three days as recorded on this instrument amounted to $2639 \mathrm{cal} / \mathrm{cm}^{2}$. The value for the three days as given in Table XII was $2376 \mathrm{cal} / \mathrm{cm}^{2}$. Using the two sets of values for the incoming radiation during both three-day periods, the ratio $I_{10} / I_{0}$ is the same: 0.86 . This corresponds well with the value in Table 41 for Period $2(20 / 6-10 / 7): 0.81$. It is very probable that the ratio $I_{10} / I_{0}$ would have been smaller on the Penny Icecap if accurate observations of the high and middle cloud had been possible.

\section{THE ALBEDO}

When evaluating the amount of heat available for melting and evaporation, it is necessary to know the albedo or reflective power of the snow surface. The albedo (a) is defined as the ratio of reflected radiation $\left(I_{r}\right)$ to total incoming radiation: $a=\frac{I_{r}}{I}$. The absorbed part of the incoming radiation is then: $I-I_{r}=I-a I=(I-a) I \equiv \alpha I$. Several investigators have measured the albedo in different locations, and it has been found that the values vary considerably with different surface conditions. Wallen ${ }^{16}$ measured albedo by turning the solarimeter upside down to measure the reflected radiation. Measurements were first made of the incoming radiation and then of the reflected radiation. 
Olsson ${ }^{17}$ used the same method. When cloud conditions change rapidly it is impossible to obtain reliable values in this manner. On the Penny Icecap albedo measurements were carried out by measuring simultaneously the incoming and reflected radiation。 Any other method would have been useless, as the fog density varied considerably even in very short time intervals. It often proved impossible to get a steady spot reading of radiation income, and to compare such a reading with one of reflected radiation taken $\frac{1}{2}$ minute or more afterwards would have given completely false results.

Instruments. W. H. Ward had constructed two radiometers which permitted simultaneous readings of incoming and reflected short-wave radiation, using two Wheatstone bridges. Figure 40 shows the two radiometers, on the left and on the centre of the stand. In this case both instruments were turned up for incoming radiation. These radiometers employed thermistor elements and in one of the instruments the white thermistor was completely shaded while the black thermistor was placed centrally under a thin glass dome. The ratio of the resistances was approximately proportional to the incoming radiation. The other radiometer consisted of two thermistors inside an evacuated round flask. In this instrument both thermistors were exposed to the sun.

Results. The albedo measurements were carried out at

$17 \mathrm{H}$. Olsson, "Radiation Measurements on Isachsen's Plateau," Geografiska Annaler, Vol. 18, Ht。3-4, 1936, p. 237. 


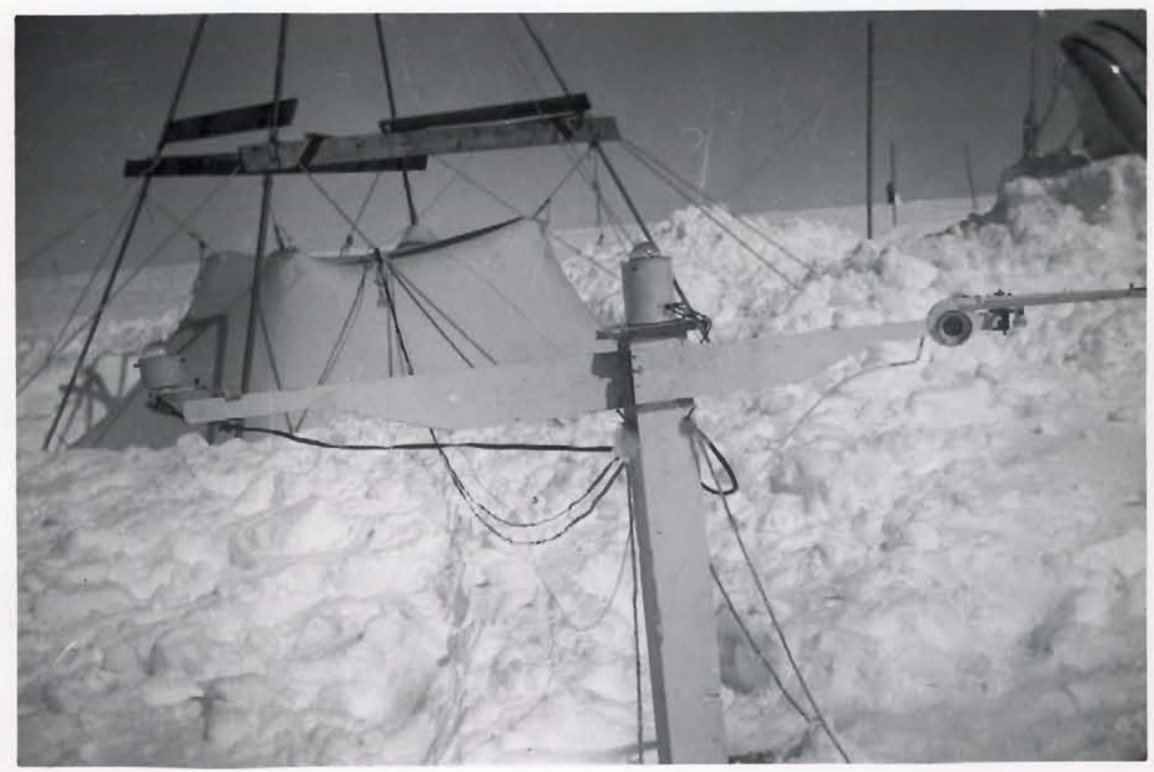

Fig. 40. Radiometers for Measurement of Albedo. 
intervals from May 22nd until August 8 th, but no observations were obtained during the three main melting periods. The mean value of four observations on July 29th was 0.77. That day had thick fog and the temperature at three feet in all observation periods was $-1.4^{\circ} \mathrm{C}=29.5^{\circ} \mathrm{F}$. Some slight snow fell during the previous evening and night. I'his corresponds well with the value 0.75 given by 01 sson 18 for cloudy conditions and new snow on the surface。

In previous investigations it has been found that over a wet snow surface there are no significant variations with different cloud conditions, and Wallen ${ }^{19}$ gives a mean value for the albedo of 0.60 , and 0lsson 0.62 . Wallen ${ }^{20}$ was of the opinion that since there have been so many studies of the albedo which agree well with each other, there is no reason for not using the values he obtained on the Karsa Glacier. He therefore used 0.60 for a wet and melting snow surface. The average of fifty-four measurements in clear weather with a frozen snow surface on the Penny Icecap gave a value for the albedo of 0.81 . This is in agreement with Kalitin's results $(0.80)$, and Prohaska's and Thams' results $(0.82)$ as cited by Wallen. There seems to be so close an agreement between these measurements that the value 0.60 for the albedo of melting snow surface has been adopted for the Penny Icecap.

\section{0lsson, 1oc. cit.}

$19 \mathrm{C}$ 。C.Wallen, "Glacial-Meteorological Investigations on the Karsa Glacier in Swedish Lappland 1942-1948," Geografiska Annaler, Vol. 30, Ht.3-4, 1948, p. 495.

20 Ibid., p. 496 . 


\section{IV 。 OUTGOING RADIATION}

The balance between incoming and outgoing radiation is of great importance in the study of the heat exchange at the icecap surface. The outgoing (long-wave) radiation from the surface can either be measured directly (compensation pyrgeometer, Angström type), or by observing the net radiative flux into or out from the snow surface. By combining those observations with measurements of incoming and outgoing short-wave radiation, it is possible to evaluate the long and short-wave components of the incoming and outgoing radiation.

Instrument. Observations of the net radiative flux were made with a Gier and Dunkle Type blown plate radiometer constructed by $W_{0} H_{0}$ Ward, using thermistors for the sensitive elements. This instrument can be seen in Figure $40(p, 139)$, on the right arm of the stand. A similar instrument has been described by Franssila。 21 The net radiation fluxmeter gives only spot measurements, and a continuous recording is not available. The readings are not complete enough for the three main melting periods to allow an evaluation of the outgoing (long-wave) radiation, and this factor has therefore been adopted from previous research in other regions.

$$
\text { The outgoing radiation, } \mathrm{R} \text {. Wallen }{ }^{22} \text { refers to previous }
$$

$21 M_{\circ}$ Franssila, "A Net Radiation Instrument with Constant Ventilation," Geophysica, Vol。4, No。3, 1953, pp。131-34。

22 Wallen, op. cit., p. 497. 
work by Angström, Linke, Johnsson and Phillips, and gives the theoretical value for the outgoing radiation for perfectly clear sky as: $R_{0}=0.142 \mathrm{cal} / \mathrm{cm}^{2}$ 。min, in the case of a melting snow surface. Wallen also calculated this value and got: $R_{0}=0.141$. It is probable that the effective outgoing radiation will increase somewhat with increasing altitude above sea level, because the back-radiation of the atmosphere must be reduced and the outgoing radiation therefore be increased. Investigations by Lauscher into this problem indicated, however, that the increase is very small up to 9-10000 feet. 23 Sverdrup ${ }^{24}$ calculated the value of $R_{0}$ (for clear sky) and $R_{f}$ (with presence of $f \circ g$ ) and adopted the value $R_{0}=0.160$. In the presence of fog the value adopted was $R_{f}=$ $0.045 \mathrm{cal} / \mathrm{cm}^{2}$ omin, in the case of an albedo value of 0.64 . There must be a close connection between the cloudiness and the effective outgoing radiation, and Angstrom 25 nas studied this relationship: $R_{c}=R_{0}\left(l-k_{0} C\right)$, where $R_{c}$ is the radiation at $\mathrm{c} / 10$ cloudiness; $\mathrm{k}$ is a constant, which varies with the type of clouds. Sverdrup ${ }^{26}$ put: $R_{c}=0.160(1-0.075 C)$ 0lsson ${ }^{27}$ got a

23 F. Lauscher, "Dampfdruck und Ausstrahlung in einem Gebirgsland," Gerl. Beitr.zur Geoph., Bd. 51, 1937, p. 234。

$24 \mathrm{H}$. U. Sverdrup, "The Eddy Conductivity of the Air over a Smooth Snow Field," Geofysiske Publikasjoner, Vol. 11, No.7, 1936, pp。37-38.

$25 \mathrm{~A}$. Angstro"m, "On the radiation and temperature of snow and convection of the air at its surface," Ark. $f_{0}$ mat., astr., och fys., Bd. 13, No. 21, 1918.

26 Sverdrup, op. cit., p.38.

$27 \mathrm{H}$. Olsson, "Sunshine and Radiation, Mount Nordenskiöld, Spitsbergen," Geografiska Annaler, Vol.18, Ht. I, 1936, p. 105. 
value for $k$ of 0.05 on Mount Nordenskiöld. This is smaller than the usually adopted value (around 0.08-0.09), and it implies that cloudiness reduces radiation less in northerly latitudes. The reason for this is that clouds in the Arctic are thinner than in lower latitudes.

During the three main melting periods on the Penny Icecap two days had 4/10-6/10 cirrus and cirro-stratus, and the remainder had fog. The value for $\mathrm{k}$ with high cloud has been given by Phillips ${ }^{28}$ as 0.045 , and Wallen ${ }^{29}$ calculated $k$ for $10 / 10$ low clouds and got 0.086 , which agreed well with Phillips' value of 0.082 for low clouds.

For the studies of conditions on the Penny Icecap we have adopted the value 0.60 for the albedo during the melting periods, and we now adopt Sverdrup's value for $R_{f}$ (which was calculated for an albedo of 0.64 ). This value is $0.045 \mathrm{cal} / \mathrm{cm}^{2}$.min. For the two days of the melting period which had an average of 5/10 high cloud we use Phillips' value for $k: 0.045$, and can then calculate the outgoing radiation on these days according to

$$
R_{c}=0.160(1-0.045 C)
$$

where $0.160 \mathrm{cal} / \mathrm{cm}^{2}$ 。min is Sverdrup's value for clear sky in West Spitsbergen.

$28 H_{0}$ Phillips, "Zur Theorie der Wärmestrahlung in
Bodennähe, "Gerl. Beitr. z. Geoph., Bd.56, 1940, p.229. 29 Wallen, op.cit., p. 500. 
CHAPTER V

\section{ABLATION MEASUREMENTS ON THE PENNY ICECAP}

Glaciological observations on the two icecaps were carried out by $\mathrm{P}, \mathrm{D}$. Baird and W. H. Ward, assisted at times by the author. The results of the glaciologica]. studies have been published, $1,2,3$ and only a short description of the ablation on the Penny Icecap will be given here.

As mentioned in Chapter I, the Barnes Icecap is an example of the "Baffin Type" icecaps; its nourishment is not by accumulation of firn but by superimposed ice from immediate refreezing of summer melt water. The Barnes Icecap does not fit readily into Ahlmann's geophysical classification of glaciers; if only temperatures are considered it must be called a "sub-polar" icecap. (Ahlmann first called this group "sub-arctic", but changed it to "sub-polar" in his 1948 paper, R.G.S. Research Series No. 1, p. 66). This group is characterized by below-freezing temperatures in the accumulation area, even in summer, to a depth of at least one hundred meters. The air temperatures, however, should be only slightly below freezing, and thaw water is found in the accumula-

I P.D. Baird, W. H. Ward and S. Orvig, "The Glaciological Studies of the Baffin Island Expedition, 1950, Parts I and II," The Journal of Glaciology, Vol. 2, No. 1l, 1952, pp。2-23.

$2 \mathrm{~S}$. Orvig, The Climate of the Ablation Period on the Barnes Ice-Cap in 1950 , thesis submitted for the degree of $\mathbb{M}_{\circ} \mathrm{Sc}$, McGill University, 1951 , pp.117-42.

3 W. H. Ward and P. D. Baird, "A Description of the Penny Ice Cap, Its Accumulation and Ablation," The Journal of Glaciology, Vol. 2, No. 15, April, 1954. 
areas of high-land ice in Baffin, Bylot, Devon and southern Ellesmere Islands are nourished in the same way, and not by accumulation of firn snow. The conditions requisite for such "Baffin Type" glaciers would seem to be (a) insufficient altitude to reach the local firn line, (b) great residual cold in the ice, (c) light precipitation, and (d) the usual Arctic climatic environment of short cool summers and lon cold winters. ${ }^{8}$ Figure 41 shows the first pit dug on the Barnes Icecap, with three feet of snow on solid ice.

As mentioned in Chapter I ( $p, 31)$, the Penny Icecap is different from its northern neighbours. It lies at a higher altitude and therefore reaches above the local firn line. Glaciological studies were carried out on the highest dome, 6725 feet, at Camp Al, and at several locations between this camp and Base Camp in Pangnirtung Pass, 1300 feet. The firn line was found to be about 5100 feet. On the tops of the domes of the underlying plateau-like rock surface the icecap is probably not very thick anywhere. Only in the cols between the heads of the major valleys is the icecap likely to be more than 1000 feet thick. On the cliffs of the valleys could be observed ice walls 150-200 feet thick, and behind them smooth domes would rise, covering what is probably an undulating plateau-like rock surface. The icecap camp was well above the firn line, and Figure 42 shows the first pit dug on the Penny Icecap. Ice crusts and layers of differing thicknesses are visible, but further digging, and boring, to a

8 Baird, op, cit, p.9. 


\section{$-147-$}

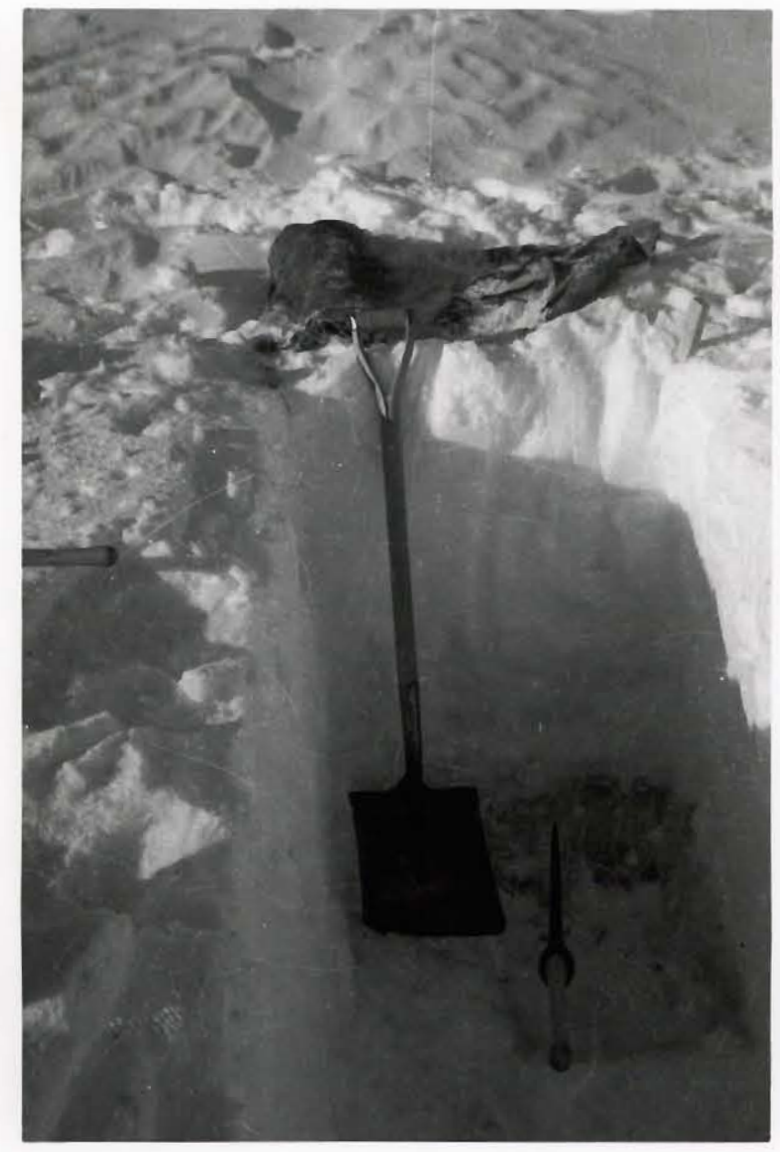

Fig. 41. The First Pit Dug on the Barnes Icecap, 1950. 
$-148-$

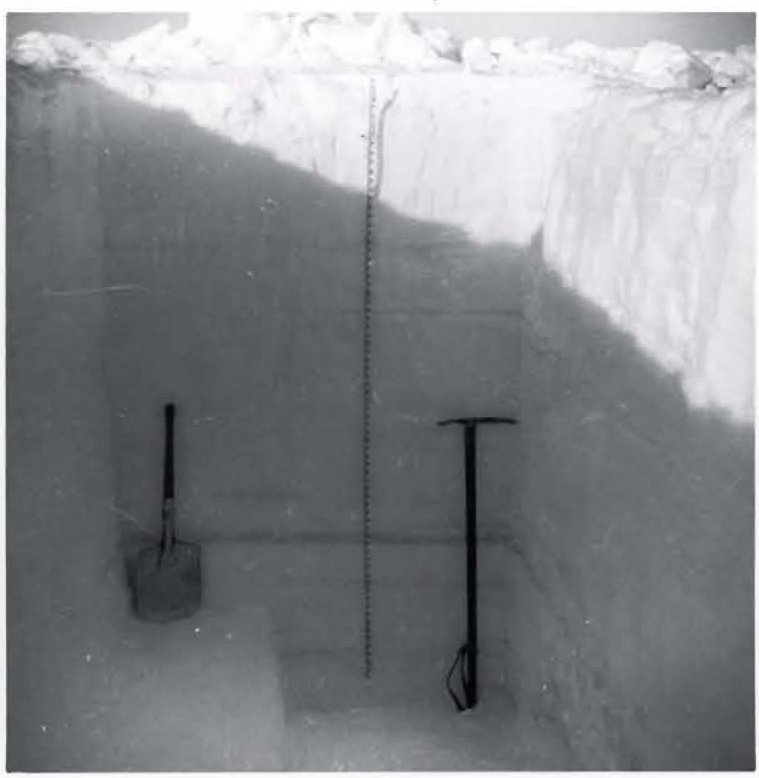

Fig. 42. The First Pit Dug on the
Penny Icecap, 1953.
(W. H. Ward) 
depth of sixty-nine feet disclosed that below the current settled snow, which was about three to four feet thick, the typical firn of the region reached to about twenty feet. It was a coarse dense firn, containing frequent layers of dense ice. From about twenty to about forty feet there was distinctly less firn and much more dense ice, and below forty-three feet there was almost entirely solid ice. 9

Similar thin ice crusts to those observed near the surface were observed in Spitsbergen and have been described by Ahlmann。 10

\section{I。 ABLATION}

The simplest method for measuring ablation is by planting stakes. A small, irregular valley-glacier with great differences in altitude demands a large number of observation posts, while on a uniform plateau-glacier or icecap, like the Barnes Icecap and the higher parts of the Penny Icecap, a smaller number suffices. The stakes used were of bamboo, a little more than seven feet long. The exposed situation of the icecap camps, with consequent drifting of snow, made it very difficult to obtain accurate measurements of ablation. It seems certain, after experience on the two icecaps, that even a specially designed instrument, such as Devik's Ablatograph, ${ }^{11}$ would not have given better results than those

\footnotetext{
$9 W_{0} H_{0}$ Ward and P. D。 Baird, "A Description of the Penny Ice Cap, Its Accumulation and Ablation," The Journal of Glaciology, Vol. 2, No. 15, April, 1954.

$10 \mathrm{H}$. W:son Ahlmann, "The Stratification of the Snow and Firn on Isachsen's Plateau," Geografiska Annaler, Vol. 17, Ht. 1-2, 1935, p. 37.

11 0. Devik, "Ein Registrierinstrument zur Messung der Ablation," Det Kgl. Norske Videnskabers Selsk. Forhandlinger, Bd, 2, No. 31, Trondhjem, 1929.
} 
obtained by the use of stakes. Ahlmann used a similar instrument on Isachsen's Plateau in 1934, and when the float was covered by a thin layer of snow, the instrument would not register the ablation. ${ }^{12}$ on the Barnes Icecap falling, drifting, or blowing snow was experienced on forty-one days out of eighty-seven, and on the Penny Icecap the same conditions were experienced on forty-three days out of eighty-one. Uinier such conditions no present method will give accurate values for the ablation.

The only way of obtaining complete knowledge of a glacier and its regime is to determine the amount of accumulation and the amount of ablation as accurately as possible under the existing conditions. On glaciers like the Penny Icecap the temperature never reaches $32^{\circ} \mathrm{F}$ all the way through, and the rain in the summertime is then also important in the accumulation, as the rain will freeze as it seeps through the frozen layers, and it is thus accumulated in the firn. In order to evaluate the yearly accumulation it is necessary to be present on the icecaps before the ablation season commences, and to stay until it is over. Especially on the Penny Icecap it was found that the ablation season was short and interrupted, and accumulation took place throughout the summer at the altitude of the icecap camp. By digging pits and measuring the density of the snow at varying depths one can calculate the amount of water accumulated during the preceding winter. The problem of accumulation is important in the glaciological in-

$12 \mathrm{H} \circ \mathrm{W}$ : son Ahlmann, "Ablation Measurements at the Headquarters on Isachsen's Plateau," Geografiska Annaler, Vol. 17, Ht. $1-2,1935$, p. 49. 
vestigation of the icecaps, their regime, etc., but the ablation is of greater interest in a meteorological study, because ablation is dependent on the different meteorological factors.

The net ablation is the water equivalent of snow and ice actually lost by the glacier or icecap. The total (gross) ablation due to melting, evaporation, wind corrasion and calving, is larger, because some of the water will be redeposited in lower layers, and some of the snow drifting on the surface will be deposited again in another place.

The ablation is measured by the sinking of the surface at a stake, and simultaneous measurements of the density of surface and underlying snow. The influence of water deposited in the firn is largely dependent on the geophysical characteristics of the glacier. In the case of the Baffin Icecaps, which are "sub-polar", some of the melt water is retained in the firn and ice, and is of importance in the regime. There is always a considerable difference between the gross ablation (calculated by means of the density of the surface snow) and the net ablation on polar icecaps. This deposition process is also common in temperate glaciers, even when the snow has for some time had a consistent temperature of $32^{\circ} \mathrm{F} .13$ Ablation measurements were made for two purposes. In order to obtain a general picture of the accumulation and ablation at different heights, stakes were placed in twelve locations. Detailed observations of ablation during short interrupted periods were

13 C。C.Wallen, "Glacial-Meteorological Investigations on the Karsa Glacier in Swedish Lappland, 1942-1948," Geografiska Annaler, Vol. 30, Ht. 3-4, 1948, p. 529. 
carried out at Camp Al. The measurements of ablation at different levels of the icecap and one of the outflowing glaciers has been described by Ward. ${ }^{14}$ Only the particular conditions at the glacier camp will be considered here.

On the Barnes Icecap the measured amounts of ablation corresponded well with the variations in temperature, depending far more on high temperatures on odd days than on the average temperature of longer periods, as established by Ahlmann. ${ }^{15}$ The temperate glaciers and most of the sub-polar glaciers have air temperatures above the freezing point in the ablation season over the whole glacier. Such was the case on the Barnes Icecap. If a sub-polar glacier or icecap is situated at a high altitude, the conditions may become similar to those of a polar glacier, where the air temperature may never rise above the freezing point. The ablation in the accumulation area becomes very small. Such was the case on the Penny Icecap.

Table XIII gives the daily snow depth on the Penny Icecap, in inches of snow. Measurements were carried out every morning, using two stakes, north and south of the camp, and the snow depth was taken from a reference level, which was a layer of dense ice, easily recognizable, at a depth of $537 / 8$ on May 21st. The measurements as given in Table. XIII are those obtained from Stake No. 1, north of the camp. The daily loss as given in this Table

14W. H. Ward and P. D. Baird, "A Description of the Penny Ice Cap, Its Accumulation and Ablation," The Journal of Glaciology, Vol. 2, No. 15, April, 1954.

$15 \mathrm{H}$. W:son Ahlmann, "The Stratification of the Snow and Firn on Isachsen's Plateau," Geografiska Annaler, Vol. 17, Ht. $1-2,1935, \mathrm{p} .41$. 
is not ablation only, because compaction and wind erosion are included in the loss of snow. More accurate measurements of the real ablation were carried out in the short periods when it took place, and will be treated below. Table XIII is only meant to illustrate the variations of the surface as indicated by one of the stakes. The snow depth increased by $21 / 8 n$ in the period from May 2lst to August 10th. The break-down of measurements for each month shows that in May (II days) the surface at Stake No. I gained $17 / 8^{\prime \prime}$ by snow, rime and hoar-frost, and lost $7 / 8^{\prime \prime}$ by compaction and erosion. In June the surface gained $145 / 8^{\mathrm{n}}$ and lost by compaction, erosion and ablation: $95 / 8^{\prime \prime}$. In July the figures were: gain, 11 3/8 and loss, $161 / 8 \%$. In August (9 days): gain, 2 5/8", loss, $16 / 8 "$. The total gain for the whole period was $304 / 8 n$, the total loss was $283 / 8 "$.

To study in more detail the ablation at the icecap camp additional stakes were planted later in the season. On June 16th three dowels were established in a line to the south of the camp, and on June 18th another two dowels were established north of the camp. Later in the season fluoresceine was also used to study the melting and seepage of melt water into the underlying firn. The ablation was so small at the altitude of Camp Al that hourly values could not be obtained. The mean variation of the ablation during the day is unobtainable in a location with only interrupted brief ablation periods. The values recorded represent the gross ablation. As these studies are concerned with the relation between ablation and meteorological factors there is no necessity for net ablation values. In the firn zone even gross ablation is difficult 
to evaluate, for surface sinking may be due not only to surface ablation, but also indirectly to the descending melt water causing compaction of the snow particles. The three main melt periods at Camp Al were preceded by a new deposit of snow, which started to melt at a density around 0.2 and finished melting at a density over 0.40 The sinking of the surface was greater than the thickness of new snow, hence an estimate based on the new snow density times the sinkage is probably an underestimate of the amount melted. $^{16}$ For an upper limit the melting could involve the total thickness of new snow and some of the denser snow beneath. In the intermittent melting period at the end of the season nearly all the sinkage originated below the top of the old firn, and a melting estimate based on the density of the old firn would be an upper limit. Working in this way, between limits, Ward has estimated that the total melt during occupation of Camp Al lies between about 10 and 15 centimeters of water. The evaporation in the firn zone was very small。

The following table shows the highest and lowest limits for the amounts of ablation at Camp Al for different periods, in centimeters of water. ${ }^{17}$

TABLE 42

ABLATION AT CAMP AI IN CM OF WATER

\begin{tabular}{lc}
\multicolumn{1}{c}{ Period } & Arnount \\
June & $0.9-0.7$ \\
lst Main & $2.4=1.8$ \\
2nd Main & $2.6=1.8$ \\
3rd Main & $4.3=3.1$ \\
Intermittent end & $5.0=3.0$ \\
Total & $15.2=10.4$
\end{tabular}

16 Ward and Baird, op. cit.

17 Personal information from W. H. Ward 


\section{PERIODS OF ABLATION}

Figure 43 shows the daily snow depth as given in Table XIII, the daily maximum temperature, the five-day running means of mean daily temperature, and days with snowfall and strong wind. The maximum wind speeds are given in $m_{\circ} p_{0} h$. Several periods can be distinguished, and these are indicated in the Figure.

There was a total of 228 hours of surface melting until August 10th, when observations ceased, and there were subsequently a few more hours of melting, judging from the snow conditions as described by other members of the Expedition, who climbed the highest mountain in Pangnirtung Pass on August 25 th and 28th. 18 The date when melting finally finished is uncertain, but the melting near the end of the summer must have been insignificant. The daily maximum temperature was above the freezing point on June 25 th, on ten days in July, and on three days early in August.

Figure 43 shows the periods of surface melting at Camp Al. There were two short periods on June $25 \mathrm{th}$ and $27 \mathrm{th}$, then came three main periods: July 13th-15th, July 19th-20th, and July 23rd26th. There then followed a number of short periods of midday melting。

Period I. June 25th to June 27th.

This short period had little effect -- on the 25 th the melting lasted 4 hours, on the 27 th only 2 hours. Period II. July 13th to July 15th。

This was the first main melting period, with 61 hours of 


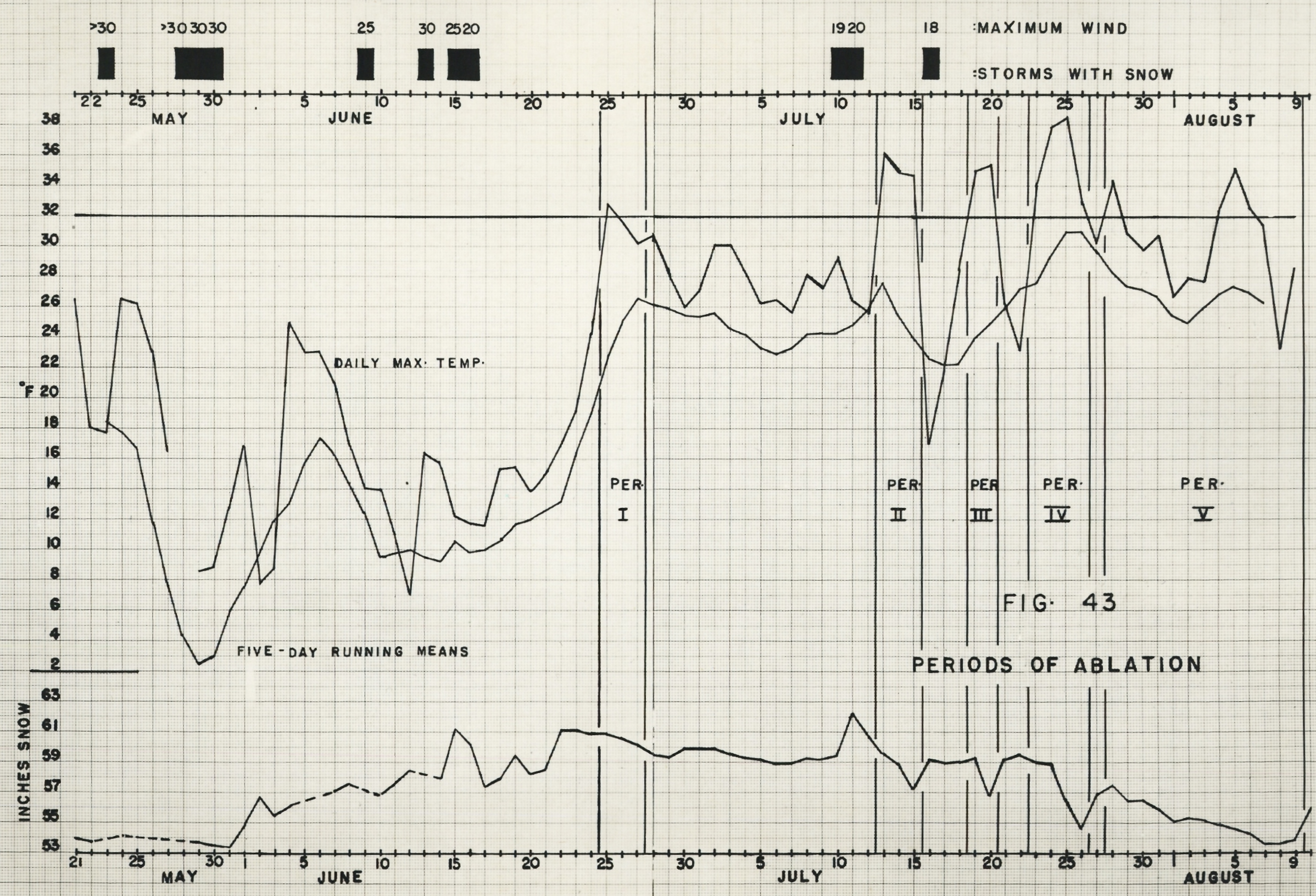


surface melting. It was a period with the daily maximum temperature above $32^{\circ} \mathrm{F}$, fairly strong wind and broken overcast. Rain was experienced on July 15th.

Period III. July 19th to July 20th。

This was the second main melting period, with 32 hours of surface melting. It was a period with two days recording maximum temperature above the freezing point, and it had thick, wet fog and rain on July 20th。

Period IV. July 23rd to July 26th。

This was the third main melting period, with 61 hours of surface melting. It had four days with maximum temperature above freezing. It had thick, wet fog and rain every day。 Period V. July 28th to August 9th。

This was a period of intermittent melting. Nine days had some melting, the periods being of varying duration: $8,9,9,10$, $3,11,11,4$ and 3 hours, totalling 68 hours. This last period had four days with maximum temperature above $32^{\circ} \mathrm{F}$. It had low overcast or wet fog, some rain and mainly light wind in the beginning, later mainly clear with light wind。

III. THE BUDGET YEAR 1952 -1953 ON THE PENNY ICECAP

To estimate the regime of a glacier or icecap, it is necessary to ascertain the total accumulation and the net ablation during a budget year. One needs to know the accumulation and ablation over the entire range of altitude of the glacier. For this purpose a series of bamboo stakes were established to measure the/relative level of the snow surface, and pits were dug as fre- 
quently as possible to record the snow profile and to measure the varying density of the settled snow. ${ }^{19}$ Ward points out that the interpretation of the pit data in the firn zone as regards the time when the various layers were formed was not simple, because: (1) the melting season was brief and intermittent, and the snow that fell during this peried was comparable in quantity to the amount that melted, (2) the melt of the current season formed ice layers within the previous year's firn, which was well below the melting point at the time, and therefore the lower limit of the previous year's firn could not be defined, (3) it was not possible to recognize any of the earlier accumulation years, (4) not the slightest trace of dirt was formed in any firn zone pit or in the deeper boring, (5) the present melt season left behind a different record of deposition to the previous year (either the melting was less, the snowfall greater or, rather unlikely, a significant amount of melting occurred after evacuation). Moreover, it was difficult to define the beginning of the next accumulation season, especially in the firn zone, because of the snowfall during the intermittent melting period. When calculating the accumulation at Camp Al the amounts of snow that blew away have been omitted, and the amounts that drifted into the area have been included. The total annual accumulation at Camp Al was about 43 centimeters of water. 20 The total settled snow and rain during the observation period amounted to 14.5 centimeters of water. As shown above

$$
\begin{aligned}
& 19 \text { Ibid. } \\
& 20 \text { Ibid. }
\end{aligned}
$$


(Table 42) the total ablation at Camp Al lies between 10 and 15 centimeters of water; this, however, was not lost to the icecap, as the melt water was redeposited in the firn, and evaporation was negligible. (See paragraph on humidity above the icecap surface, pp。 $83-88$.

The total accumulation, ebiation and net loss or gain of water is summarized for the various altitudes in the following table. The errors should be within $\pm 3 \mathrm{cms}$ 。 in the worst cases。 21

\section{TABLE 43}

\section{REGIME OF THE PENNY ICECAP}

\begin{tabular}{|c|c|c|c|c|c|}
\hline \multirow[b]{2}{*}{$\begin{array}{l}\text { Elevation } \\
\text { meters }\end{array}$} & \multirow[b]{2}{*}{$\begin{array}{c}\text { Elevation } \\
\text { feet }\end{array}$} & \multicolumn{4}{|c|}{ Centimeters of water } \\
\hline & & $\begin{array}{c}\text { Total } \\
\text { Accumulation }\end{array}$ & $\begin{array}{l}\text { Total } \\
\text { Ablation }\end{array}$ & $\begin{array}{l}\text { Net } \\
\text { Loss }\end{array}$ & $\begin{array}{r}\text { Net } \\
\text { Gain }\end{array}$ \\
\hline $\begin{array}{l}440 \\
750 \\
1010 \\
1060 \\
1300 \\
1380 \\
1600 \\
1630 \\
1920 \\
1940 \\
2050\end{array}$ & $\begin{array}{l}1444 \\
2461 \\
3314 \\
3478 \\
4265 \\
4528 \\
5249 \\
5348 \\
6300 \\
6365 \\
6725\end{array}$ & $\begin{array}{l}38 \\
40 \\
41 \\
36 \\
40 \\
40 \\
37 \\
39 \\
63 \\
60 \\
43\end{array}$ & $\begin{array}{r}268 \\
154 \\
118 \\
97 \\
66 \\
48 \\
? \\
? \\
? \\
? \\
10 ? 15\end{array}$ & $\begin{array}{r}222 \\
106 \\
70 \\
52 \\
18 \\
0 \\
\vdots \\
\vdots \\
\vdots \\
-\end{array}$ & $\begin{array}{r}- \\
\infty \\
\infty \\
0 \\
>12 \\
39 \\
63 \\
60 \\
43\end{array}$ \\
\hline
\end{tabular}

The 1952-1953 accumulation, equal to the ablation, at the equilibrium line was 40 centimeters of water.

IV。A COMPARISON OF GLACIERS

The quantity of water deposited in the firn or on underlying ice surfaces in the accumulation area depends largely on 
the geophysical character of the glacier. According to Ahlmann it may rise to 100 per cent of the water present during the ablation season on a sub-polar glacier。 ${ }^{22}$ The thickness of the superimposed ice at the main camp on the Barnes Icecap was such that failure to take it into account when determining the regime of the icecap would have given ccinpletey false results. The gross ablation there was $48.8 \mathrm{cms}$. of water and the water equivalent of new ice on the surface $11.5 \mathrm{cms}$, leaving a net ablation of $37.3 \mathrm{cms}$. of water. $^{23}$ The melting process as observed on the Barnes Icecap was strikingly similar to that observed in North East Land, Spitsbergen, and described by several authors. Sandford, 24 Ahlmann, 25 and Glen ${ }^{26}$ all mention the overwhelming influence upon the conditions of the surface by thaw.

The similarity between the Barnes Icecap and icecaps in Spitsbergen is a direct result of the relatively similar meteorological conditions mentioned previously $(p, 66)$. Ahlmann has studied the different conditions on several glaciers, and in a diagram he has plotted the values of accumulation = ablation at

22 HoW:son Ahlmann, "The Froya Glacier in 1939-40," Geografiska Annaler, Vol。28, Ht。3-4, 1946, p。25l。

$23 \mathrm{~W}$. H. Ward and So Orvig, "The Heat Exchange at the Surface of the Barnes Ice Cap during the Ablation Period," The Journal of Glaciology, Vol。2, No.13, 1953, p.162.

$24 \mathrm{~K}$. S. Sandford, "The Glacial Conditions and Quaternary History of North East Land," The Geographical Journal, Vol.74, 1929, p. 465.

$25 \mathrm{H}$. W:son Ahlmann, "Scientific Results of the SwedishNorwegian Arctic Expedition in the Summer of 1931, Part 8: Glaciology," Geografiska Annaler, Vol。15, Ht。2-3, 1933, pp。201-06。

26 A. R。 Glen, "A sub-arctic glacial cap: the West Ice of North East Land," The Geographical Journal, Vol.98, 1941, p。139. 
the firn line and the altitude of the firn line above sea level。 27 The relative positions of the points give a good idea of the regimes and characteristics which are conditioned by the climate. This diagram is presented here as Figure 44, the only difference being the addition of the Karsa Glacier and the Barnes and Penny Icecaps. The average height of the firn limit on the Karsa Glacier was 1150 meters, and the accumulation $\mathrm{s}$ ablation at this level averaged $196 \mathrm{cms}$ 。 of water。 ${ }^{28}$ On the Barnes Icecap the lower limit of the accumulation area was about 2460 feet $(750$ meters), and the accumulation = ablation at this equilibrium line was calculated to be $51 \mathrm{cms}$ 。 of water. ${ }^{29}$ On the Penny Icecap the firn line was found to lie at about 5085 feet (1550 meters). The equilibrium line, where there was neither a gain nor a loss of water, was found about 4528 feet ( 1380 meters)。 The accumulation = ablation at this equilibrium line was $40 \mathrm{cms}$. of water. ${ }^{30}$ When plotting Figure 44 the values for the equilibrium line have been used for the two Baffin Island icecaps。

$27 \mathrm{H} . \mathrm{W}:$ son Ahlmann and S。Thorarinsson, "The Vatnajökull Glacier. Preliminary Report on the Work of the Swedish-Icelandic Investigations 1936-1937," The Geographical Review, Vol。28, No。 3, 1938, fig。 11 , p。 431。

$28 \mathrm{C}$. C.Wallen, "Glacial-Meteorological Investigations on the Karsa Glacier in Swedish Lappland 1942-1948," Geografiska Annaler, Vol。 $30, \mathrm{Ht}$, 3-4, 1948, po559.

29 P。D。Baird, W。H。Ward and So Orvig, "The Glaciological Studies of the Baffin Island Expedition, 1950" "The Journal of Glaciology, Vol, 2 , No, $11,1952, \mathrm{p}, 8$ 。

$30 \mathrm{~W}, \mathrm{H}$. Ward and $\mathrm{P} \circ \mathrm{D}$. Baird, "A Description of the Penny Ice Cap, Its Accumulation and Ablation, "The Journal of Glaciology, Vol. 2, No。15, April, 1954。 
ACCUMULATION= ABLATION AT THE FIRN LINE, AND ITS ALTITUDE

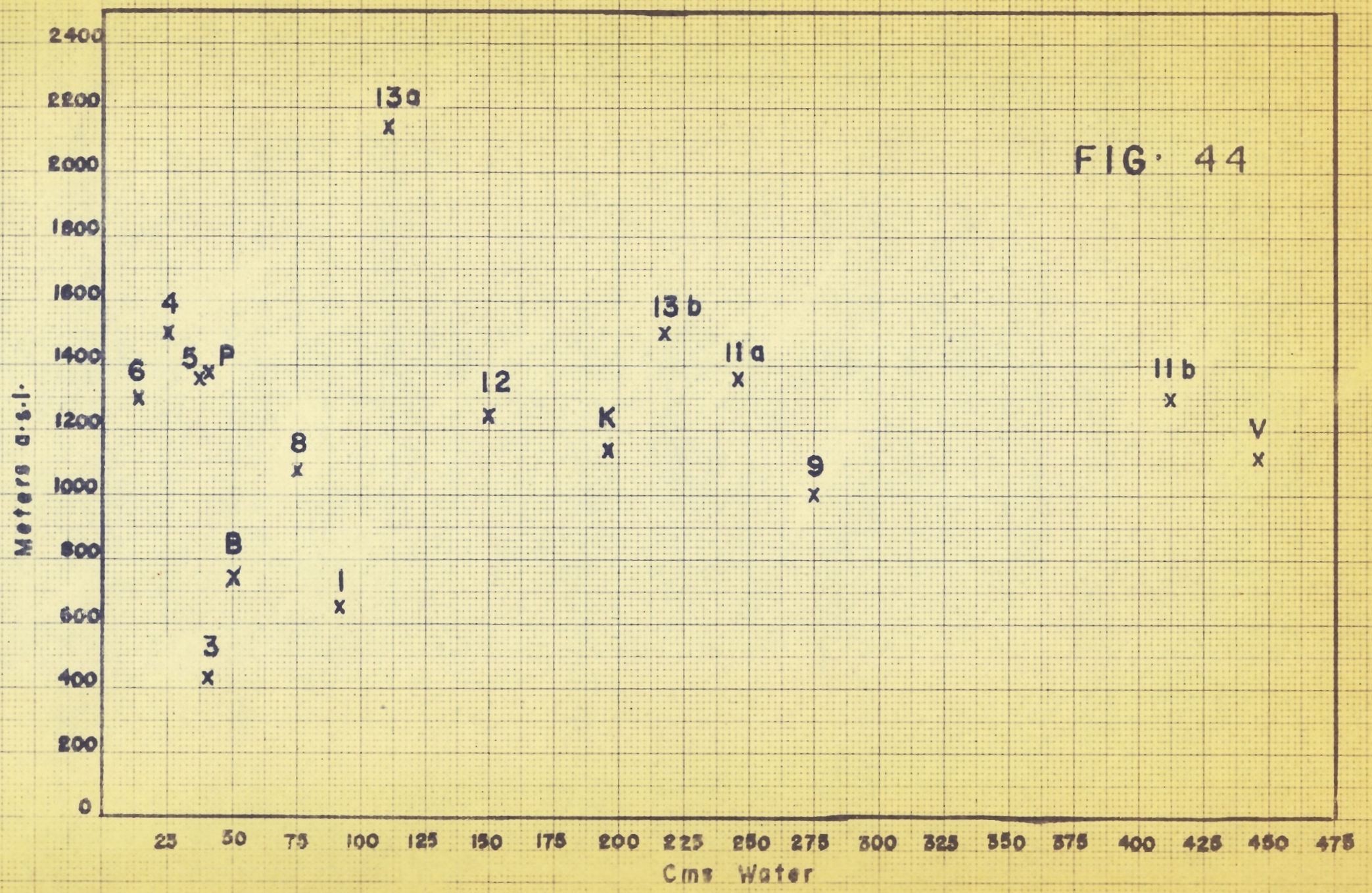


In Figure 44 the different glaciers represented are: V: Vatnaj8kkull, Iceland。

Ilb, 9, Ila: Norwegian coastal glaciers. 13b, 12, 13a: Norwegian inland glaciers。

4, 5, 6, 8: Glaciers in East Greenland $(8$ is central part of East Greenlaraj。

1: Fourteenth of July Glacier, West Spitsbergen。

3: North East Land, East Spitsbergen.

K: Karsa Glacier, northern Sweden.

B: Barnes Icecap, Baffin Island。

P: Penny Icecap, Baffin Island。

The grouping of the different glaciers is caused by the difference in climate. The Barnes Icecap is situated between the Fourteenth of July Glacier, which has arctic-maritime climate, and North East Land, which has arctic-continental climate resulting in a low firn line and small accumulation a ablation. The Penny Icecap is practically identical to one of the three Green land examples, which are characterized by small precipitation and consequently high firn lines. The Karsa Glacier has a regime definitely higher than that of the sub-polar glaciers, but considerably smaller than that of Vatnajökull and the Norwegian coastal glaciers. It is more like some of the Norwegian inland glaciers. As Wallen ${ }^{31}$ has pointed out, this is quite reasonable from a climatological point of view. The total value of the regime of

31 Wallen, op。cito, po56l。 
a glacier normally increases with the maritimity of the region. The relation of the firn line altitude to the accumulation (ablation) depends on both the amount of precipitation and the temperature of the ablation period. Temperature variations are generally of more importance to the life of a glacier than variations in precipitation。 ${ }^{32}$ In East Greenland the high firn line is due to the small accumulation, and also to the relatively high summer temperature. As mentioned above, the temperatures in west Spitsbergen are very similar to those on the Barnes Icecap, therefore the nearly equal altitude of the firn line in the two locations. The difference in precipitation, however, causes a displacement of the Barnes Icecap to the left in Figure 44, towards the more continental glaciers.

The extensive glaciation of Greenland, in spite of the small precipitation, is made possible by the insignificant ablation in the vast accumulation areas。 33 Conditions are reversed in maritime Iceland. Vatnajökull resembles the Alfot Glacier, a Norwegian coastal glacier (1lb)。They are both maritime types, with relatively low firn lines and very large accumulation : ablation.

Ahlmann states that not only are most of the world's glaciers retreating, but in many regions the present retreat is

32 H.W: son Ahlmann, "Researches on Snow and Ice, 191840," The Geographical Journal, Vol. 107, 1946, p。19.

33 H. W:son Ahlmann, "Accumulation and Ablation on the Fröya Glacier, its Regime in 1938-39 and 1939-40," Geografiska Annaler, Vol。24, Ht。1-2, 1942, po 15. 
the most rapid ever recorded 34 The glacier caps of North East Land are practically dead, and the Fröya Glacier in North East Greenland is almost dead. 35 The reason for this wasting away of the glaciers around the North Atlantic is probably a change in the horizontal pressure gradient, resulting in increased advection of warm air to the regions around the northernmost part of the Atlantic。 Petterssen ${ }^{36}$ has shown that the northward atmospheric transport has increased since the year 1900 over the eastern part of the North Atlantic region with a maximum increase in Scandinavia. The southward transport of the air has increased noticeably in the Greenland-Labrador-Newfoundland area. Although the increase in the meridional transport (positive toward the north) may be said to account for the increase in temperature in the European area, it is clearly incapable of explaining the simultaneous increase in temperature in Labrador, Newfoundland, and parts of Greenland. Thus, the general mechanism of the clima tic variation cannot everywhere be associated with increased advection of air from more southerly latitudes. 37

$34 \mathrm{H}$. W: son Ahlmann, "Den nutidiga klimatfluktuationen och dess utforskande," Norsk Geografisk Tidsskrift, Bd。Il, Nos。 $3-4,1947, \mathrm{pp}, 304=05$ 。

$35 \mathrm{H}$. W:son Ahlmann, "Researches on Snow and Ice, 1918 40," The Geographical Journal, Vol。107, 1946, p。14 and p。21。

$36 \mathrm{~S}$. Petterssen, "Changes in the General Circulation Associated with the Recent Climatic Variation," Geografiska Annaler, Vol。31, Ht。1-4, 1949, po216。

37 Ibid。, p。217。 
The most important cause of the reduction in ice area is the negative regime created by the great ablation, which is due to the increased transfer of heat through the atmosphere. Wallen 38 concludes from his study of the Karsa Glacier that the increased heat supply from the air is in turn caused by increased summer temperatures, increased suinier huridity, and a prolongation of the ablation season.

The problem of the increase in atmospheric circulation into the Arctic is not well known in the Canadian arctic regions, ${ }^{39}$ and it is not possible to state that it can be readily detected from observations on the Barnes Icecap. All indications were that the icecap is nearly stationary and not receding. Vegetation grows right up to its edge, there is obvious activity on the ice cliffs in the lakes, and on the ground one could observe the form mation of moraines. 40 The Barnes Icecap is too small to cause a large degree of cooling and direct self-preserving effects through increased precipitation. The climate of the region is continental in winter, and there is no direct accumulation of snow. Because of the low temperature of the ice, however, accumulation of new ice takes place above a certain equilibrium line, and it may be said that the icecap is selfopreserving in an unusual sense. The

$38 \mathrm{C} . \mathrm{C}$. Wallen, "The Shrinkage of the Karsa Glacier and its Probable Meteorological Causes," Geografiska Annaler, Vol. 31, Ht. 1-4. 1949, po290。

39 R。 Scherhag, "Die Erwarmung der Arktis," Journal Conseil Permanent International pour l'Exploration de la Mer, Vol. 12, $1937, \mathrm{pp} .263-76$ 。

40 P。D。Baird, W。H。Ward and S。Orvig, "The Glaciological Studies of the Baffin Island Expedition, 1950," The Journal of Glaciology, Vol。2, No。11, 1952, pp。3-4。 
equilibrium line will move up or down the icecap depending on the summer temperatures.

The Penny Icecap region showed that the outflowing glaciers are noticeably retreating, and visual observations throughout the area by various members of the expauition showed that a general increase in the extent of glaciation at least 150-200 years ago had been followed by a retreat which began about 50 years ago, and which is still notably in progress. 41 It is therefore prom bable, but not absolutely certain that the Penny Icecap proper regularly has a negative regime at the present time. 42

Ice temperatures were observed by thermistors buried at various depths. The deepest at the icecap station was placed at sixty-nine feet. The steady temperature below the zone of seasonal change was about $-13.3^{\circ} \mathrm{C}\left(8^{\circ} \mathrm{F}\right)$. This is considered to be about the mean annual air temperature, and it is readily under stood that a very marked increase in air temperatures would be necessary before a shrinkage of the present icecaps could take place at this altitude. However, a prolongation of the ablation season, and higher summer temperatures would certainly be noticed in increased ablation in the lower altitudes. This is taking place.

$4 I W_{0} H_{0}$. Ward and P.D.Baird, "A Description of the Penny Ice Cap, Its Accumulation and Ablation," The Journal of Glaciology, Vol. 2, No. 15, April, 1954 . 42 Cfoante, pp。29-30。 
CHAPTER VI

THE HEAT EXCHANGE AT THE ICECAP SURFACE

On the Barnes Icecap the conditions were found to be favourable for a study of the heat exchange between the atmosphere, the melting snow, and the lucierlying ice during the ablation period. This exchange has been described as taking place in two stages. At the snow surface the atmospheric heat turns snow into water, and at the original ice surface some of this water is transformed back. into ice and the latent heat is yielded downwards. A theoretical estimate of the rate of formation of super-imposed ice, and of the temperature change in the original ice, agreed well with the actual measurements。 ${ }^{1}$ The observations were de= ficient in precise measurements of incoming and outgoing radiation, and in night-time observations of humidity and wind. The estimate of the amount of heat received by the snow from the atmosphere was restricted, therefore, to the total received during the ablation period.

The relationship between ablation and the meteorological conditions has only been studied since $19310^{2}$ The most important study of the heat exchange at a snow surface was carried out by

I w. H. Ward and So Orvig, "The Heat Exchange at the Surface of the Barnes Ice Cap during the Ablation Period," The Journal of Glaciology, Vol。2, No。13, 1953, pp。158-68.

2 A. Angstrom, "On the Dependence of Ablation on Air Temperature, Radiation and Wind," Geografiska Annaler, Vol。15, Ht. 4, 1933, pp. 264-71。 
Sverdrup, ${ }^{3}$ who also used his formulas in an analysis of the dependence of ablation on different meteorological elements. Sverdrup's conclusions have been used in all later investigations of this kind, and the present study joins those of the Vatnajökull in Iceland, 4 the Fröya Glacier in North East Greenland, 5 and the Karsa Glacier in northern Sweden。 5 Wallen notes, however, that his study of the Karsa Glacier showed that the conditions there are in many ways different to those on Isachsen's Plateau, 7 and it was necessary to modify Sverdrup's theories in such a way as to be applicable to the particular conditions existing on the Karsa Glacier。

\section{THE HEAT EXCHANGE}

The snow surface receives heat by incoming (short-wave) radiation from sun and sky (I), by conduction and convection from the air above the surface if the air temperature increases with

$3 H_{0} U_{\circ}$ Sverdrup, "The Eddy Conductivity of the Air over a Smooth Snow Field," Geofysiske Publikasjoner, Vol. Il, No.7, 0slo, 1936, pp.1-69.

$4 \mathrm{H}$.W:son Ahlmann and S. Thorarinsson, "Scientific Results of the Swedish-Icelandic Investigations 1936-37-38, Part V: Ablation," Geografiska Annaler, Vol。20, $\mathrm{Ht}, 3-4,1938, \mathrm{pp}, 17 \mathrm{l}-$ 233.

5 B. E。 Eriksson, "Meteorological Records and the Ablation on the Froya Glacier in Relation to Radiation and Meteorological Conditions," Geografiska Annaler, Vol。24, Ht. 1-2, 1942, pp.2350 .

$6 \mathrm{C}$. Co Wallen, "Glacial-Meteorological Investigations on the Karsa Glacier in Swedish Lappland 1942-1948," Geografiska Annaler, Vol。30, Ht。3-4, 1948, pp。45l-672。

7 Ibid.g p. 570。 
height $\left(Q_{a}\right)$, by conduction from below if the temperature of the snow increases with depth $\left(Q_{S}\right)$. Heat is also received by the surface if the water content of the air increases with height. Water vapour is then transported to the surface and condensation of the water vapour will release the heat of condensation. The amount of water condensed will be indicated by $F$ grs.

The snow surface loses heat by outgoing (Iong-wave) radiation $(R)$, by conduction and convection to the air above the surface if the air temperature decreases with height $\left(-Q_{Q}\right)$, by conduction downwards if the temperature of the snow decreases with depth $\left(-Q_{S}\right)$. Heat is also lost if the water content of the air decreases with height. Water is then evaporated from the surface, and the heat of evaporation will be taken from the surface. The amount of water evaporated will be indicated by $-F$ grs 。

Some of the incoming radiation is lost due to reflection。 If the albedo of the snow is called a $(=$ reflected radiation divided by total incoming radiation) the absorbed part of the incoming radiation will be $I-a I=(I-a) I=\alpha I$ 。

The heat transported to the surface by all processes is used to raise the temperature of the surface snow to the melting point and for evaporation. After the melting point has been reached the heat is used for melting and evaporation. It is convenient to give all amounts of heat in gram calories per square centimeter. The total ablation of the surface, measured in $\mathrm{cm}$. of water will be called $H$, the water equivalent of the layer which is evaporated is $\mathrm{h}$, and the water equivalent of the layer which is 
melted is, therefore, $(\mathrm{H}-\mathrm{h})$. To melt one gram of snow takes 80 gr.calories, and 680 gr.calories are needed for evaporating one gram of snow. The amount of heat used for melting is therefore: $80(\mathrm{H}-\mathrm{h})$, and for evaporation: $680 \mathrm{~h}$ 。

If melting and evaporation take place we have: 8

$$
\alpha I-R \pm Q_{a} \pm Q_{S}=80(t-h)+680 h
$$

or $\quad \alpha I-R \pm Q_{a} \pm Q_{S}=80 \mathrm{H}+600 \mathrm{~h}$

But $h$ (evaporated water) $=-F$, so the equation takes the form

$$
\alpha I=R \pm Q_{a} \pm Q_{s}=80 \mathrm{H}-600 \mathrm{~F} \text {. }
$$

Here $F$ is negative, since water vapour is transported away. When no evaporation takes place, the heat equation takes the form

$$
600 F+\alpha I-R \pm Q_{a} \pm Q_{s}=80 H
$$

(600 gr.calories is the amount of heat liberated by condensation of one gram of water vapour). This equation can be written

$$
80 H-600 F \approx \alpha_{0} I R \pm Q_{a} \pm Q_{s}
$$

This equation is therefore valid both in the case of melting and evaporation and in the case of melting only, but $F$ must be given the proper sign: positive in the case of condensation, negative in the case of evaporation.

The periods of ablation on the Penny Icecap were: June 25 th and June 27 th, July 13 th to 15 th, July 19th to 20th, July $23 \mathrm{rd}$ to $26 \mathrm{th}$, and intermittent between July 28.th and August 9th. The surface snow temperature was measured three times daily, with the help of a thermistor buried $\frac{3}{4}$ inch below the surface, and during the ablation periods the surface temperature was very close 
to the melting point, although it was found that during the first main melting period, in July, pockets of water fed from the surface were situated in snow as cold as $-3^{\circ} \mathrm{C}$. Temperature conditions were quite complex, also during the second main melting period. During and after the third main melting period the whole profile was melting well down into the ca firn. ${ }^{9}$ It may be assumed that the upper layers of snow had a temperature of $0^{\circ} \mathrm{C}$ during the periods of ablation, and that the term $Q_{s}$ in the heat equation may therefore be disregarded. The equation then takes the form

$$
80 \mathrm{H}=\alpha I-\mathrm{R} \pm \mathrm{Q}_{\mathrm{a}}+600 \mathrm{~F}
$$

A calculation of the contribution of each of the different terms in the equation to the total melting and evaporation is possible, because we have the values of $\mathrm{H}$ for the periods of ablation, and we have also the values of $I$ and $\alpha$ and. $R$ for the same periods. The most difficult problem is the determination of convection and conduction, and of condensation and evaporation, expressed by the terms $Q_{\mathrm{a}}$ and 600F.

II. TRANSFER OF HEAT AND WATER VAPOUR THROUGH THE AIR

The exchange of heat occurs by conductional and convec tional processes; the exchange of water vapour is governed by the eddy conductivity. In order to ascertain the values of $Q_{a}$ and $F$ for the periods of ablation, it is therefore necessary to discuss

9 W。 H。 Ward and P。D。Baird, "A Description of the Penny Ice Cap, Its Accumulation and Ablation," The Journal of Glaciology, Vol. 2, No。15, April, 1954。 
the problem of eddy conductivity and convectivity. Sverdrup 10 has studied, on a broad basis, the problem of heat exchange within the layer of air next to the ground, and he applied the results from the Norwegian-Swedish Spitsbergen Expedition, 1934, to this theoretical study。

The convection term iqa Considering first the transfer of heat, a study by Nyberg ${ }^{I l}$ gives the value of the term $Q_{a}$ :

$$
Q_{a}: c_{p} \cdot A \cdot \frac{d \theta}{d z} \cdot T
$$

$c_{p}$ is the specific heat of air at constant pressure $(0.24$ cal/grot) $A$ is the eddy conductivity coefficient $(\mathrm{gr} / \mathrm{cm} . \mathrm{sec}), \frac{d \theta}{d z}$ is the vertical gradient of potential temperature. $T$ is the time interval in seconds. The dimension of $Q_{a}$ is $\mathrm{cal} / \mathrm{cm}^{2}$

The value of $A$ at a particular height above the surface is a function of the wind velocity at that height, and of the temperature and wind velocity gradients. It is therefore necessary to examine the variations in temperature and wind velocity with height. Wallen ${ }^{12}$ noted that in meteorological studies it can be assumed that the average wind velocity increases with height according to a power law of the form

$10 \mathrm{H} \circ \mathrm{U}$. Sverdrup, "The Eddy Conductivity of the Air over a Smooth Snow Field," Geofysiske Publikasjoner, Vol. 11, No. 7, Oslo, 1936, pp。1-69.

11 A Nyberg, "Temperature Measurements in an Air Layer very close to a Snow Surface," Geografiska Annaler, Vol. 20, Ht. $3-4,1938, p .247$.

12 C.C. Wallen, "Glacial-Meteorological Investigations on the Karsa Glacier in Swedish Lappland, 1942-1948," Geografiska Annaler, Vol. 30, Ht。3-4, 1948, po 572。 


$$
u=u_{1} \cdot\left(\frac{z_{1}}{z_{1}}{ }^{1 / n_{u}}\right.
$$

where $u$ is the speed at height $z$, and $u_{1}$ at height $z_{1}$. Different investigations have obtained different values for $\mathrm{n}_{\mathrm{u}}$, according to the various conditions under which the investigations were carried out. However, under certain conditions; such as over a rough surface, a logarithmic law may better indicate the wind speed gradient. It has been found ${ }^{13}$ that a power law best represents the conditions under stable conditions, while the logarithmic law fits best if the stratification is unstable. On the Barnes Icecap, where wind observations were carried out at two heights, and where the stratification was stable for 78 per cent of the time, the wind speed was found to increase with height according to the power law. 14 The value of $\mathrm{n}_{\mathrm{u}}$ was found to be 4.9 .

On the Penny Icecap the stratification was far more unstable (see Table 24), especially early in the season. During the three main melting periods, however, which are the only cases studied here, the stratification was mainly stable. The average wind speeds were almost identical on the two icecaps (see page 95), and we may therefore assume that the wind velocity on the Penny Icecap increased with height according to the equation

$$
\frac{u}{u_{1}}=\left(\frac{z}{z_{l}}\right)^{1 / n_{u}}
$$

13 Sverdrup, op. cit., p. 12.

14 W. H. Ward and So Orvig, "The Heat Exchange at the Surface of the Barnes Ice Cap during the Ablation Period, "Journal of Glaciology, Vol. 2, No. 13, 1953, p. 167. 
where $\mathrm{n}_{\mathrm{u}}$ has the value of 4.9 . This assumption is probably justified, not only because the stratification was stable during the ablation periods, but also because both icecaps are large and quite horizontal and the meteorological conditions were therefore not influenced by local effects.

To find the temperature gradient during the three main melting periods the averages of the two-hourly daytime potential temperatures at three and twenty-three feet (91 and $701 \mathrm{~cm}$ ) above the surface have been calculated for each period. For the three periods the mean daytime potential temperatures at the two levels were, in degrees $C$ 。:

$\begin{array}{cccc}3 \text { feet }(91 \mathrm{~cm})) & \text { lst period } & \text { 2nd period } & \text { 3rd period } \\ 23 \text { feet }(701 \mathrm{~cm}): & 1.01 & 0.46 & 0.29 \\ 1.29 & 0.57 & 0.40\end{array}$

These temperatures vary with height according to

$$
\frac{\theta}{\theta_{1}}=\left(\frac{z}{z_{1}}\right)^{1 / n_{\theta}}
$$

where $\theta$ is the potential temperature at height $z$, and $\theta_{1}$ at height $z_{1}$, and where $n_{\theta}$ takes a slightly different value for each period. The values for $n_{\theta}$ for the three main melting periods are:

$$
n_{\theta_{1}}=8.3 \quad n_{\theta_{2}}=9.5 \quad n_{\theta_{3}}=6.3
$$

Wallen ${ }^{15}$ noted that Sverdrup assumed and was able to show that the wind and temperature distribution followed the same type of a power law, where the value of the power $\mathrm{n}$ was the same in both cases. It is not certain, however, that the same value of $n$ is

15 Wallen, op, cit., p. 582 . 
applicable for both wind and temperature distribution in other areas. Wallen found a difference in his study of conditions on the Karsa Glacier, and on the Barnes Icecap ${ }^{16}$ the value for $n_{u}$ was found to be 4.9 , whereas the value for $n_{\theta}$ was 2.2 . The small value for $\mathrm{n}_{\theta}$ on the Barnes Icecen, compared with the three higher values on the Penny Icecap, arrees with Sverdrup's and Wallen's ${ }^{17}$ results that there is a decrease of $n_{\theta}$ with increasing stability。 Wallen ${ }^{18}$ found values for $n_{\theta}$ varying between 2.1 and 13.6 。 As the value for $n_{u}$ is not a function of the stability of the air, it seems reasonable to use the value 4.9 for all three ablation periods, whereas the value for $\mathrm{n}_{\theta}$ will be different for each period, as mentioned above. Wallen ${ }^{19}$ concluded that it is not reasonable to apply Sverdrup's values to other glaciers without a study of the laws governing exchange of momentum and heat in every particular case. It is therefore necessary to determine in every new area of investigation the n-values, which govern the heat balance conditions above the glacier surface. It is to be expected that the values will be different in regions where topographical features make the wind and temperature conditions above the surface more complicated than those over a flat, smooth surface of considerable extent.
16 Ward and Orvig, 10c.cit.
17 Wallen, op。cit., po 587.
18 Ibid., p. 588 .
19 Ibid., p. 593. 
The values for $\mathrm{n}_{\mathrm{u}}$ and $\mathrm{n}_{\theta}$ for the three main melting periods on the Penny Icecap are reasonable in relation to Wallen's study, and in these circumstances the equation for the eddy conductivity used by Wallen 20 has been adopted:

$$
A=k \times 10^{-4} \cdot u_{Z} \circ z\left(\frac{n_{0}-1}{n_{\theta}}-\frac{1}{n_{u}}\right)
$$

From this equation it is evident that the eddy conductivity at a particular height $\mathrm{z}$ must be a function of the wind velocity at that height and also of the temperature and velocity gradients $\left(n_{\theta}\right.$ and $\left.n_{u}\right)$. It follows then that the convection term is

$$
Q_{a}=c_{p} \times 1 \cdot 4 \times 10^{-4} \cdot u_{z} \cdot z\left(\frac{n_{\theta}-1}{n_{\theta}}-\frac{1}{n_{u}}\right) \cdot \frac{d \theta}{d z} \cdot T
$$

where $c_{p}$ is the specific heat of air at constant pressure 10.24 $\left.\mathrm{cal} / \mathrm{gr} \cdot{ }^{\circ} \mathrm{C}\right), u_{z}$ is the mean wind speed at six feet $(183 \mathrm{~cm}$ ) in $\mathrm{cm} . / \mathrm{sec}, \mathrm{z}$ is $183 \mathrm{~cm}, \mathrm{n}_{\theta}$ takes on a different value for each of the three melting periods: $8.3,9.5,6.3$, and $n_{u}$ is $4.9 . \frac{d \theta}{d z}$ is the mean vertical gradient of potential temperature, in ${ }^{\circ} \mathrm{C} / \mathrm{cm}$ 。 $T$ is the time interval in seconds. On substituting the values for each term in equation (12), the convectional heat can be calculated for each of the three main melting periods. As the temperature increased with height over the surface during all three periods, the value of $Q_{a}$ will be positive in the heat equation.

The condensation term 600F. The exchange of water vapour governed by the eddy conductivity may be calculated from a formula

20 Ibid., p. 597. Wallen actually used $\mathrm{k}=1.8$, while Sverdrup found $\mathrm{k}, 1.4$ on Isachsen's Plateau. As the conditions are relatively similar on the Baffin Island icecaps and on Isachsen's Plateau, the value 1.4 has been adopted here. 
analogous to the one expressing the convection term ${ }^{21}$

$$
F=A \cdot \frac{d f}{d z} \cdot T=A \cdot \frac{0.623}{p} \cdot \frac{d e}{d z} \cdot T
$$

where $A$ and $T$ have the same meanings as above, $f$ is the specific humidity, $e$ is the vapour pressure and $p$ the atmospheric pressure.

On the Barnes Icecap it was found that on the average during the ablation period there was a net decrease in vapour pressure with height, and hence a net evaporation. A study of the individual observations showed that the gradient was irregular。 ${ }^{22}$ Often there was an increase in vapour pressure from the surface to $92 \mathrm{~cm}$, followed by a decrease higher up. It was therefore not reasonable to assume that the vapour pressure and the temperature distributions followed the same laws.

The humidity distribution will vary according to the stability conditions, the normal condition is that $\frac{d e}{d z}<0 \quad i_{0} e$. water is evaporated from the surface. However, above a melting snow surface the conditions are mostly the opposite: $\frac{d e}{d z}>0$ because the vapour pressure at the melting surface is fixed at $4.58 \mathrm{~mm}$. The air above generally has a higher value. If dry air moves over the melting icecap surface the humidity will increase from the surface in the air layer very close to it, but decrease at higher levels. Such was frequently the case on the Barnes Icecap. On

$21 \mathrm{H} \cdot \mathrm{U}_{0}$ Sverdrup, "The Eddy Conductivity of the Air over a Smooth Snow Field," Geofysiske Publikasjoner, Vol。1l, No.7, 1936, p. 39。

22 W. H. Ward and S. Orvig, "The Heat Exchange at the Surface of the Barnes Ice Cap during the Ablation Period, "Journal of Glaciology, Vol.2, No。13, 1953, p。167. 
the Penny Icecap fog was very frequent, also in the ablation periods, and the vapour pressure and the temperature therefore very probably followed the same power law. Wallen ${ }^{23}$ found that there was no considerable difference between the laws governing the heat and humidity transport $i_{i 1}$ the two-meter air layer above the glacier surface, and both Sverdrup and Wallen came to the conclusion that the indices of the power laws governing the vapour pressure and the temperature distribution $\left(n_{e}\right.$ and $\left.n_{\theta}\right)$ are equal.

As the power law is considered to be the same for temperature and humidity, $\mathrm{A}$ is identical in equations (7) and (13). The condensation term is then

$$
F=1.4 \times 10^{-4} \cdot u_{z} \cdot z\left(\frac{n_{\theta^{-1}}}{n_{\theta}}-\frac{1}{n_{u}}\right) \cdot \frac{0.623}{p} \cdot \frac{d e}{d z} \cdot T(14)
$$

where $u_{z}$ is the mean wind speed at six feet $\left(183, \mathrm{~cm}_{0}\right)$ in $\mathrm{cm}, / \mathrm{sec}$, $z$ is $183 \mathrm{~cm}, \mathrm{n}_{\theta}$ takes on a different value for each of the three melting periods: $8.3,9.5,6.3$, and $n_{u}$ is $4.9 \%$ is the mean atmospheric pressure at the icecap station $(\mathrm{mm} \mathrm{Hg})$, and $\frac{\text { de }}{\mathrm{dz}}$ is the mean vertical gradient of vapour pressure, in $\mathrm{mm} \mathrm{Hg} / \mathrm{cm}$. T is the time interval in seconds. The dimension of $\mathrm{F}$ is $\mathrm{gr} . / \mathrm{cm}^{2}$. On substituting the values for each term in equation (14), the heat of condensation can be calculated for each of the three main melting periods. As the vapour pressure increased with height over the surface during all three periods, the value of $F$ will be positive in the heat equation. 
CHAPTER VII

\section{ABLATION AS A FUNCTION OF RADIATION AND METEOROLOGICAL FACTORS}

In the study of conditions on the Barnes Icecap a detailed investigation of the importance of the different meteorological factors in the ablation was prohibited by a lack of instruments for measuring radiation, However, Sverdrup's simplified formula was used to compute the ablation on certain specified days. This computed ablation was then compared with the observed ablation on those days ${ }^{1}$ It must be borne in mind that the relationships discovered by Sverdrup ${ }^{2}$ do not hold in all cases. Both Sharp ${ }^{3}$ and Ahlmann ${ }^{4,5}$ quote Wallen's results from the Karsa Glacier in Sweden, where Sverdrup's relationships were found not to hold。 The importance of the different meteorological factors in ablation vary from one morphological type of glacier to another. Very recent (1953) observations from the Lemon Creek Glacier in Alaska

I S. Orvig, The Climate of the Ablation Period on the Barnes Ice-Cap in 1950 , thesis presented for the degree of $\mathrm{M}_{0} \mathrm{Sc}_{\circ}$ McGill University, 1951, $\mathrm{pp}$ 。153-58.

$2 \mathrm{H}$. U. Sverdrup, "The Eddy Conductivity of the Air over a Smooth Snow Field," Geofysiske Publikasjoner, Vol. 11, No.7, 1936, pp. $1-69$.

3 R。P.Sharp, "Glacial-Meteorological Investigations in Swedish Lappland: Review Article," Arctic, Vol. 3, No. 2, 1950, p. 115 .

$4 \mathrm{H}$.W:son Ahlmann, "The Contribution of Polar Expeditions to the Science of Glaciology," The Polar Record, Vol. 5, Nos。 $37-38,1949, p 。 328$.

$5 \mathrm{H}$. W:son Ahlmann, "Glacier Variations and Climatic Fluctuations," Bowman Memorial Lectures, Series 3, 1953, p。7. 
are only in a preliminary stage of evaluation, but there are indications that long-wave radiation from clouds to the snow was more important than insolation in the total heat exchange. 6 Previous investigations on the heat balance over a snow surface have not mentioned the importance of long-wave radiation in the transfer of heat to the surface. As more work is being done on radiation problems it is probable that it will be found necessary to consider the heat radiated from thick clouds, at least in the case of clouds with higher temperatures than the snow. However, in the case of the Baffin Island icecaps it is to be expected that the importance of long-wave radiation in transferring heat to the snow is negligible. There is rather a net outgoing radiation due to lower air and cloud temperatures and less cloudiness than experienced on the Juneau Ice Field. The two icecaps studied in Baffin Island are similar in many respects to Isachsen's Platw eau in West Spitsbergen, where Sverdrup carried out his heat exw change studies. Not only are those icecaps relatively level and situated at altitudes of several thousand feet, but the climatic conditions have much in common and, most important, the meteorological conditions are not influenced by topographical factors. Sverdrup applied his simplified formula to observations from North East Land as well as West Spitsbergen, and the results were consistent. He was of the opinion that the formula probably can be

\footnotetext{
Washington。

6 Personal information from $R$ 。 C. Hubley, University of
} 
applied at other localities, 7 and the results of the computation of ablation on the Barnes Icecap according to Sverdrup's formula suggested that the formula will give accurate results, if the necessary information is available regarding radiation and meteorological factors. 8

The simplified formula combines the effects of the factors which influence the ablation, but the relative importance of the different factors is quite obscured. A knowledge of the effects of the separate meteorological elements on the ablation is only possible if a continuous and complete record of radiation is available for the whole ablation season.

On the Penny Icecap the ablation took place in short, interrupted periods, and it is possible to apply the results of the meteorological and radiation studies to the problem of ablation in the three main melting periods. In Chapter VI the heat equation was given as:

$$
80 \mathrm{H}=\alpha I-R \pm Q_{a}+600 F
$$

where $F$ is positive in the case of condensation, and negative in the case of evaporation. It was further mentioned in Chapter VI that for the three main melting periods on the Penny Icecap both $Q_{a}$ and $F$ were positive in the heat equation. This then takes the form:

7 H. U. Sverdrup, "The Ablation on Isachsen's Plateau and on the Fourteenth of July Glacier in Relation to Radiation and Meteorological Conditions," Geografiska Annaler, Vol. 17, Ht. 3-4, 1935, p. 163.

8 Orvig, op. cit., p. 158 . 


$$
\begin{gathered}
-183- \\
80 \mathrm{H}=\alpha I-R+Q_{a}+600 F
\end{gathered}
$$

where $\mathrm{H}$ is the ablation measured in cms. of water; $\alpha=(1-a)$, where $a$ is the albedo of the snow surface; I is the total incoming (short-wave) radiation from sun and sky; $R$ is the outgoing (longwave) radiation from the surface; $Q_{a}$ is the heat transported to the surface by conduction anci convection; and $600 \mathrm{~F}$ is the heat transported to the surface by condensation. The value of $Q_{a}$ is expressed by equation (12), and that of $F$ by equation (14), both in Chapter VI.

As mentioned in the paragraph on Humidity (pp. 83-88), it was found to be practically impossible to obtain reliable humidity observations at low temperatures, and at temperatures close to the freezing point. As pointed out on pp。 84-85 all investigators on glaciers and icecaps have found that accurate measurements of humidity have caused difficulties.

Sharp 9 pointed out that some method is sorely needed for measuring ablation of snow and firn with an accuracy and reliability equivalent to that with which the meteorological factors are measured. It is not an easy task to develop such a method, but it is essential to the balancing of the ablation equation. This difficulty in measuring ablation was experienced on the Baffin Island icecaps also, and there are therefore two factors in the ablation equation which are difficult to obtain with satisfactory accuracy: the ablation and the vertical gradient of vapour pressure. 


\section{THE FIRST MAIN MELTING PERIOD}

This period began at 0700 on July 13 th, and lasted until 2000 on July $15 \mathrm{th}$, or a total of 61 hours. The mean daily relative humidity for the three days was 86, 91 and 100 per cent. Rain fell on July 15th.

The value of $\mathrm{H}$ for this period is $2.4-1.8 \mathrm{cms}$. of water (Table $42, p .154$ ). The value of $\alpha$ is 0.40 , because the value 0.60 for the albedo of melting snow has been adopted for the Penny Icecap (p. 140). The total incoming radiation (I) for the 61 hours amounted to $1659 \mathrm{cal} / \mathrm{cm}^{2}$. The value of $\mathrm{R}$ (out-going radiation) can be calculated from the values given in Chapter IV, paragraph IV. In fog we have adopted the value $R_{f}=0.045 \mathrm{cal} / \mathrm{cm}^{2}$. min. Parts of two of the days of the first main melting period had an average of 5/10 high cloud, a total of 27 hours, and the outgoing radiation is then: $R_{5}=0.160(1-0.045 \times 5) \mathrm{cal} / \mathrm{cm}^{2} \cdot \min$. The total value for $R$ is therefore:

$(0.045 \times 60 \times 34) \mathrm{cal} / \mathrm{cm}^{2}+(0.160(1-0.225) \times 60 \times 27) \mathrm{cal} / \mathrm{cm}^{2}=292.7 \mathrm{cal} / \mathrm{cm}^{2}$. The value of $Q_{a}$ (conductional and convectional heat) can be calculated from equation (12), (p. 177):

$$
Q_{a}=c_{p} \times 1.4 \times 10^{-4} \times u_{z} \times z\left(\frac{\left(n_{\theta_{1}}-1\right.}{n_{\theta_{1}}}-\frac{1}{n_{u}}\right) \times \frac{d \theta}{d z} \times T
$$

where $c_{p}$ is $0.24 \mathrm{cal} / \mathrm{gr} .{ }^{\circ} \mathrm{C} ; u_{z}$ is $676.37 \mathrm{~cm} / \mathrm{sec} . ; z$ is $183 \mathrm{~cm}$; $n_{\theta_{1}}=8.3$; and $n_{u}=4.9$. For the first main melting period $\frac{d \theta}{d z}=$ $0.00046^{\circ} \mathrm{C} / \mathrm{cm}$. $T=60 \times 60 \times 61$. The value for $Q_{a}$ is therefore: $Q_{a}=77.5 \mathrm{cal} / \mathrm{cm}^{2}$. 
The amount of heat liberated by condensation, 600F, can be calculated from equation (14), (p. 179):

$F=1.4 \times 10^{-4} \times u_{z} \times z\left(\frac{n_{\theta 1}-1}{n_{\theta_{1}}}-\frac{1}{n_{u}}\right) \times \frac{0.623}{p} \times \frac{\mathrm{de}}{\mathrm{dz}} \times \mathrm{T}$ where $u_{z}$ is $676.37 \mathrm{~cm} / \mathrm{sec} . ; z$ is $183 \mathrm{~cm} \cdot ; n_{\theta_{l}}=8.3 ; n_{u}=4.9$; $p=584.72 \mathrm{~mm} . \mathrm{Hg} . ;$ and $\frac{d e}{d z}=0.0001 \mathrm{~mm} \cdot \mathrm{Hg} \cdot / \mathrm{cm} . \mathrm{T}=60 \times 60 \times 61$. On page 179 it was stated that the vapour pressure increased with height over the surface during all three periods, and that the value of $F$ is therefore positive in the heat equation. This is true for the second and third melting periods, and also true, as an average, for the first period. However, 27 hours of the total 61 hours of the first melting period had no fog, and the mean vertical gradient of vapour pressure was then negative, indicating evaporation from the surface. For the remaining 34 hours the mean vertical gradient of vapour pressure was positive, indicating condensation. For the period as a whole the mean vertical gradient of vapour pressure was positive: $\frac{d e}{d z}=0.0001 \mathrm{~mm} . \mathrm{Hg} . / \mathrm{cm}$, , and the resultant value of $F$ is positive in the heat equation. The amount of heat liberated by condensation is therefore: $600 \mathrm{~F}=44.8 \mathrm{cal} / \mathrm{cm}^{2}$. We can now calculate the theoretical ablation ( $\mathrm{H} \mathrm{cms.)} \mathrm{for}$ the first melting period:

$$
\begin{gathered}
8 \mathrm{OH}=0.4 \times 1659-292.7+77.5+44.8=493.2 \mathrm{cal} / \mathrm{cm}^{2} \\
\mathrm{H}=6.2 \mathrm{cms} \text {. water }
\end{gathered}
$$

This is 2.6 times as much as the maximum of the observed value, which lies between 2.4 and $1.8 \mathrm{cms}$. This, however, is not unduly high, as it has been supposed in this calculation that the value 
$-Q_{S}$-- the heat lost to the underlying snow -- was zero. As mentioned on pp. $171-172$ it was observed that melt water was present in snow as cold as $-3^{\circ} \mathrm{C} .10$ A total loss downwards of $301.2 \mathrm{cal} / \mathrm{cm}^{2}$ during this period would balance the equation and give $H=2.4 \mathrm{cms}$. This means an average value for $-Q_{S}$ of 0.00137 $\mathrm{cal} / \mathrm{cm}^{2}$.sec., and to balance tise heat equation with the minimum value of observed ablation $(H=1.8)$ would give a total value for $-Q_{s}$ of $349.2 \mathrm{cal} / \mathrm{cm}^{2}$, or an average of $0.00158 \mathrm{cal} / \mathrm{cm}^{2} . \mathrm{sec}$. It is certain that there was heat conduction through the snow during this first melting period, as the temperature decreased with depth from the very surface, and the value for $-Q_{S}$ : $0.0014-0.0016 \mathrm{cal} / \mathrm{cm}^{2}$. sec. is reasonable as shown in the following.

The speed with which heat is transferred into the snow by conduction, not considering the trickling down of melt water, depends on the temperature gradient and the thermal conductivity of the snow. This latter is given by $b=c a l / c m .{ }^{\circ} \mathrm{C} . \mathrm{sec}$. , and with a temperature gradient in the snow of $t{ }^{\circ} \mathrm{C} / \mathrm{cm}$ the following amount of heat will pass through $1 \mathrm{~cm}^{2}$ per second: b.t $\mathrm{cal} / \mathrm{cm}^{2}$. sec. Many different values are given for the thermal conductivity of snow. Geiger ${ }^{l l}$ gives for old snow: 0.0007 and for freshly fallen

10 Sverdrup described "pockets" of cold firn surrounded by melting firn ("The Temperature of the Firn on Isachsen's Plateau and General Conclusions regarding the Temperature of the Glaciers on West-Spitsbergen," Geografiska Annaler, Vol. 17, Ht. $1-2,1935, \mathrm{p} .79)$. On the Penny Icecap it was found that "pockets" of melt water were surrounded by cpld firn, i.e., more of the latter.

11 R. Geiger, The Climate Near the Ground. Cambridge: Harvard University Press, 1950, Table 9, p. 28. 
snow: $0.0002 \mathrm{cal} /{ }^{\circ} \mathrm{C} . \mathrm{cm} . \mathrm{sec}$. Variables such as density, crystal structure and orientation are responsible for the lack of agreement in the results of a great number of investigations. Abels $^{12}$ was one of the first to study the problem of heat conduction in snow, and for snow densities of $0.14<\rho<0.34$ he found $b=0.0068 \rho^{2} \mathrm{cal} /{ }^{\circ} \mathrm{C} . \mathrm{cm}$.sec., which for a density of 0.33 $\mathrm{gr} / \mathrm{cm}^{3}$ gives $\mathrm{b}=0.0007$, and this value corresponds to Geiger's values above. Some of the more recent investigations give only slightly different results; those calculated by The Cooperative Snow Investigation were based on the diurnal temperature variation at different depths in a natural snow cover, and gave a value: ${ }^{13} \mathrm{~b}=18.3 \rho \times 10^{-4}$, which for density of $0.33 \mathrm{gr} / \mathrm{cm}^{3}$ gives: $\mathrm{b}=0.0006 \mathrm{cal} /{ }^{\circ} \mathrm{C} . \mathrm{cm} \cdot \mathrm{sec}$.

From recent studies Reuter ${ }^{14}$ has drawn the conclusion that the transfer of heat in the highest layers of snow must make up about 7-8 times the figures given in literature by Abels and others, who have based their calculations on investigations of the diurnal waves of temperature in snow layers. It must be borne in mind that no detailed investigations of thermal conductivity of snow are, as yet, available from locations where

12 H. Abels, "Beobachtungen der täglichen Periode der Temperatur im Schnee und Bestimmung der Warmeleitvermbgens des Schnees als Funktion der Dichte," Rep. Meteor. Petersburg, Bd.16, No. 1, 1892, pp. 31-32.

13 Review of the Properties of Snow and Ice. SIPRE Report No. 4, University of Minnesota, July, 1951, p. 55.

$14 \mathrm{H}$. Reuter, "Uber die Theorie des Wärmehaushaltes einer Schneedecke," Archiv für Meteorologie, Geophysik und Bioklimatologie, Serie A, Bd. 1, Ht. 1, 1948, p. 63 . 
the temperature gradient is as steep as that on the Penny Icecap ${ }^{15}$ Even during the first main melting period, when melt water actually had trickled down into the snow, was the temperature gradient in the upper $30-40 \mathrm{cms}$. of snow as steep as $0.113^{\circ} \mathrm{C} / \mathrm{cm}$., and calculated for a deeper layer it was even steeper.

Using Reuter's value for $\mathrm{b}: 0.006 \mathrm{cal} /{ }^{\circ} \mathrm{C} . \mathrm{cm} . \mathrm{sec}$. and $\mathrm{a}$ temperature gradient of $0.113^{\circ} \mathrm{C} / \mathrm{cm}$., we obtain a heat loss by conduction of $0.0007 \mathrm{cal} / \mathrm{cm}^{2} . \mathrm{sec}_{0}$, which is one half of the amount necessary to balance the heat equation. However, considering the impossible task of obtaining accurate ablation measurements, the very cold firn under the top layers of snow (causing a probably larger heat loss than that calculated above), and the complex temperature conditions in the snow, we may take the values as calculated in this paragraph as reasonable indications of the relative importance of the different meteorological factors in the process of ablation during the first melting period.

II. THE SECOND MAIN MELTING PERIOD

This period began at 1200 on July 19th, and lasted until 2000 on July 20 th, or a total of 32 hours. The mean daily relative humidity for the two days was 99 and 100 per cent. July 20 th had very thick fog.

\footnotetext{
15 Sverdrup, op. cit., p. 82, mentions that it was in tended to undertake a detailed investigation of temperatures at depths in order to obtain data for computing the heat conductivity of the snow. However, the observations gave no information about the conductivity as the snow reached the melting point early in the ablation period.
} 
The value of $\mathrm{H}$ for this period was $2.6-1.8 \mathrm{cms}$. of water (Table 42, p. 154). The value of $\alpha$ is 0.4 as for the first period. The total incoming radiation for the 32 hours amounted to 583 $\mathrm{cal} / \mathrm{cm}^{2}$. The period had continuous fog and the outgoing radiation was therefore: $\mathrm{R}=(0.045 \times 60 \times 32) \mathrm{cal} / \mathrm{cm}^{2}=86.4 \mathrm{cal} / \mathrm{cm}^{2}$. The value of $Q_{a}$ is again calculated from:

$$
Q_{a}=c_{p} \times 1.4 \times 10^{-4} \times u_{z} \times z\left(\frac{n_{\theta_{2}-1}}{n_{\theta}}-\frac{1}{n_{u}}\right) \times \frac{d \theta}{d z} \times T
$$

where $c_{p}$ is $0.24 \mathrm{cal} / \mathrm{gr} \cdot{ }^{\circ} \mathrm{C}_{\text {; }} u_{z}$ is $530.86 \mathrm{~cm} / \mathrm{sec}$; $z$ is $183 \mathrm{~cm}$; $n_{\Theta_{2}}=9.5$; and $n_{u}=4.9$. $\frac{d \theta}{d z}$ is now: $0.00018^{\circ} \mathrm{C} / \mathrm{cm}$; and $T$ is $60 \times 60 \times 32$.

The value for $Q_{a}$ for this second ablation period is therefore: $Q_{a} \approx 13.5 \mathrm{cal} / \mathrm{cm}^{2}$.

The value of $600 \mathrm{~F}$ is again calculated from:

$$
F=1.4 \times 10^{-4} \times u_{z} \times z\left(\frac{n_{\theta_{2}}-1}{n_{\theta}}-\frac{1}{n_{u}}\right) \times \frac{0.623}{p} \times \frac{d e}{d z} \times T
$$

where $u_{z}$ is $530.86 \mathrm{~cm} / \mathrm{sec} . ; z$ is $183 \mathrm{~cm} . ; n_{\theta_{2}}=9.5 ; n_{u}=4.9$; $\mathrm{p}=579.35 \mathrm{~mm} \cdot \mathrm{Hg}$. and $\frac{\mathrm{de}}{\mathrm{dz}}=0.0005 \mathrm{~mm} \cdot \mathrm{Hg} \cdot / \mathrm{cm}$. $\mathrm{T}=60 \times 60 \times 32$. The mean vapour pressure at 23 feet $(701 \mathrm{~cm}$ ) was $4.9022 \mathrm{~mm}$. Hg, and the mean temperature was $0.94^{\circ} \mathrm{C}$. This corresponds well with Sverdrup's ${ }^{16}$ vapour pressure at $500 \mathrm{~cm}$. on days with $>3 \mathrm{~m} / \mathrm{sec}$ wind and temperature $0.9-1.9^{\circ} \mathrm{C}: 4.89 \mathrm{~mm} . \mathrm{Hg}$. The value of $600 \mathrm{~F}$ is: $100.9 \mathrm{cal} / \mathrm{cm}^{2}$.

We can now calculate the theoretical ablation ( $\mathrm{H} \mathrm{cms}$ ) for the second melting period:

16 H.U. Sverdrup, "The Eddy Conductivity of the Air over a Smooth Snow Field," Geofysiske Publikasjoner, Vol. 11, No. 7, 1936, Table 2, p. 28. 


$$
\begin{gathered}
80 \mathrm{H}=0.4 \times 583-86.4+13.5+100.9=261.2 \mathrm{cal} / \mathrm{cm}^{2} \\
H=3.3 \mathrm{cms} . \text { water }
\end{gathered}
$$

This is 0.7 cms. more than the maximum of the observed value, which lies between 2.6 and $1.8 \mathrm{cms}$. This must be considered to be very close to the observed value, as a certain amount of heat was lost to the underlying snow also during the second melting period (p. 172). This amount, $-Q_{S}$, has not been allowed for in the above calculation. A total heat loss downwards of $53.2 \mathrm{cal} /$ $\mathrm{cm}^{2}$ would balance the equation and give $\mathrm{H}=2.6 \mathrm{cms}$. This is an average value for ${ }^{-Q_{S}}$ of $0.00046 \mathrm{cal} / \mathrm{cm}^{2}$.sec., a very probable value. To balance the heat equation with our minimum value for observed ablation $(H=1.8)$ would give a value for $-Q_{S}$ of 117.2 $\mathrm{cal} / \mathrm{cm}^{2}$, or an average value of $0.0010 \mathrm{cal} / \mathrm{cm}^{2} . \mathrm{sec}_{0}$, also a value of the expected order of magnitude. The values calculated in this paragraph are therefore good indications of the relative importance of the different meteorological factors in the process of ablation during the second melting period.

III. THE THIRD MAIN MELTING PERIOD

This period began at 2000 on July 23rd, and lasted until 0900 on July 26th, or a total of 61 hours. The mean daily relative humidity for the four days was 99, 99, 100 and 100 per cent. The whole period had thick fog, and hoar-frost was observed on July 23 rd.

The value of $\mathrm{H}$ for this period was $4.3-3.1 \mathrm{cms}$. of water (Table 42, p. 154). The value of $\alpha$ is 0.4 as for the two other 
main melting periods. The total incoming radiation for the 61 hours amounted to $897 \mathrm{cal} / \mathrm{cm}^{2}$. The period had continuous fog; the outgoing radiation was therefore: $R=(0.045 \times 60 \times 61)$ cal/ $\mathrm{cm}^{2}=164.7 \mathrm{cal} / \mathrm{cm}^{2}$. The value of $Q_{a}$ is again calculated from:

$$
Q_{a}=c_{p} \times 1.4 \times 10^{-4} \times u_{z} \times 2\left(\frac{n_{\theta_{3}} 1}{n_{\theta_{3}}}-\frac{1}{n_{u}}\right) \times \frac{d \theta}{d z} \times T
$$

where $c_{p}$ is $0.24 \mathrm{cal} / \mathrm{gr}_{\circ}{ }^{\circ} \mathrm{C}_{;} u_{z}$ is $308.46 \mathrm{~cm} / \mathrm{sec}_{0} ; \mathrm{z}$ is $183 \mathrm{cms}$; $n_{\theta_{3}}=6.3 ;$ and $n_{u}=409$. $\frac{d \theta}{d z}$ is now: $0.00018^{\circ} \mathrm{C} / \mathrm{cm}_{\circ} ;$ and $T=$ $60 \times 60 \times 61$. The value for $Q_{a}$ for this third ablation period is therefore: $Q_{a}: 11.3 \mathrm{cal} / \mathrm{cm}^{2}$ 。

The value of $600 F$ is again calculated from:

$$
F=1.4 \times 10^{-4} \times u_{z} \times z\left(\frac{n_{\theta_{3}} I}{n_{\theta_{3}}}-\frac{1}{n_{u}}\right) \times \frac{0.623}{p} \times \frac{\mathrm{de}}{\mathrm{dz}} \times \mathrm{T}
$$

where $u_{z}$ is $308.46 \mathrm{~cm} / \mathrm{sec}_{0} ; \mathrm{z}$ is $183 \mathrm{cms} ; \mathrm{n}_{\theta_{3}}=6.3 ; \mathrm{n}_{\mathrm{u}}=4.9$; $p=582.27 \mathrm{~mm} \cdot \mathrm{Hg}_{\circ} ;$ and $\frac{\mathrm{de}}{\mathrm{dz}} \approx 0.0012 \mathrm{~mm}$. Hg。/cm。 $\mathrm{T}=60 \times 60 \times 61$ 。 The mean vapour pressure at 23 feet $(701 \mathrm{cms}$ ) was $5.41 \mathrm{~mm}$.Hg。。 and mean temperature was $2.4^{\circ} \mathrm{C}$. This corresponds well with Sverdrupis 17 vapour pressure at $500 \mathrm{cms}$ 。 on days with $>3 \mathrm{~m} / \mathrm{sec}$ wind and temperature $\$ 1.9^{\circ} \mathrm{C}: 5.58 \mathrm{~mm}$. $\mathrm{Hg}$. The value of $600 \mathrm{~F}$ is: $202.0 \mathrm{cal} / \mathrm{cm}^{2}$.

We can now calculate the theoretical ablation ( $\mathrm{H} \mathrm{cms}$ ) for the third melting period:

$$
\begin{aligned}
80 \mathrm{H}=0.4 \times 897 & =164.7+11.3+202.0 \approx 407.4 \mathrm{cal} / \mathrm{cm}^{2} \\
H & =5.1 \mathrm{cms} \text { owater }
\end{aligned}
$$

This is $0.8 \mathrm{cms}$. more than the maximum of the observed value, 
which lies between 4.3 and $3.1 \mathrm{cms}$. This must be considered to be close to the observed value. The top layer was now melting, and conduction of heat downwards $\left(-Q_{S}\right)$ was probably negligible; to balance the equation and obtain $\mathrm{H}=4.3 \mathrm{cms}$ 。 we must account for a total of $63.4 \mathrm{cal} / \mathrm{cm}^{2}$. This is an average of $0.00029 \mathrm{cal} /$ $\mathrm{cm}^{2}$.sec。, which can be explained by a very small heat conduction downwards or by the uncertainty in ablation and humidity values. The values calculated in this paragraph are therefore good indications of the relative.importance of the different meteorological factors in the process of ablation during the third melting period.

\section{IMPORTANCE OF RADIATION, CONVECTION AND CONDUCTION,} AND CONDENSATION

The relative significance of radiation, convection and conduction, and condensation in ablation varies not only with altitude and the general character of the climate, but also with the latitude. Radiation is greatest in high-lying parts; at low altitudes the convection is of greater importance than radiation, as observed in West Spitsbergen and North East Land. ${ }^{18}$ As a general rule it is also true that the relative importance of the different factors changes from the beginning of the ablation season to its end. ${ }^{19}$ The influence of radiation usually diminishes

I8 H.W:son Ahlmann, "The Contribution of Polar Expeditions to the Science of Glaciology," The Polar Record, Vol. 5, Nos, 3738,1949, p. 328.

19 H. W:son Ahlmann, "Glacier Variations and Climatic Fluctuations," Bowman Memorial Lectures, Series 3, 1953, p.7. 
after late June, and radiation becomes more important with decreasing latitude. In a continental and arid climate (e.g०o Peary Land) the evaporation becomes of greatest importance in the ablation process. 20

The Penny Icecap station was situated on the highest dome。 The results are therefore not completely representative of the conditions between the firn line and this highest point. Also, due consideration must be paid to the uncertainty of some of the observations, as conditions were very unfavourable for obtaining accurate measurements. Conditions may also change from year to year, although for the region as a whole the weather was average (p.42)。The assumptions on which the calculations are based are, of necessity, rough. As a reconnaissance of an unknown icecap the results may, however, be used in a comparison with other well explored glaciers and icecaps around the North Atlantic。

During the three main melting periods on the Penny Icecap the heat received at the surface by the different factors was as set forth in the following table. Some evaporation took place during the 27 first hours of Period 1, but on the whole evaporation was insignificant because of the high moisture content of the air, and because the temperatures were above the freezing point. This is in accordance with results from other research North Greenland," Assemblee Generale de Bruxelles, $U_{0} G_{0} G_{0} I_{0}{ }_{1251}$ Tome I, Louvain, 1952, p。189. 
in Sweden, Spitsbergen and Greenland. 21 Between July 28 th and August 9 th nine days had some ablation, but the periods were short and interrupted, lasting from three to eleven hours. The period had mainly thick fog or low overcast; only 72 hours of the whole period had no fog at the station, and less than 5/10 clouds. Humidity values were high even then, and only August $3 \mathrm{rd}$ and 4 th could possibly have had evaporation. However, no noticeable ablation was measured on those days.

TABLE 44

HEAT SUPPLY AND PERCENTAGE IMPORTANCE

$$
\mathrm{cal} / \mathrm{cm}^{2}
$$

$\frac{\text { available radiation convec. \& conduc. condensation total }}{\alpha I \infty R} \frac{Q_{a}}{\%} \frac{600 \mathrm{~F}}{\%} \frac{\mathrm{cal} / \mathrm{cm}^{2}}{\mathrm{Q}_{\mathrm{a}}}$

Period $1: 370.9$ Period 2: 146.8 Period 3: 194.1 Total:

\section{2}

56.2

47.6

61.3
77.5

13.5

11.3
15.7 5.2 2.8 $8.8 \quad 347.7$
44.8 100.9 202.0
9.1493 .2 $38.6 \quad 261.2$ $49.6 \quad 407.4$

As a total for the three main periods of ablation on the Penny Icecap, then, the heat was mainly supplied by radiation (61.3 per cent). Next in importance was condensation (29.9 per cent); convection and conduction supplied only 8.8 per cent. The season was so short that a variation with time of the heat supply for ablation could not be detected. There was a diminishing importance of radiation from Period 1 to Period 3, but the three melting periods spanned over only a total of thirteen days, and Annaler, Vol. 30, Ht. 3-4, 1948, p. 603, and p. 609. 
the diminishing radiation is therefore not due to the seasonal factor, but rather to cloud and fog conditions. For the same reason (brief ablation season) nothing can be said about the varias tion of importance of conductional and convectional heating, which normally should increase from the heginning to the end of the ablation season. The concissational heat supply accounted for 30 per cent, from about 9 per cent in the period with partly clear or overcast weather, to 50 per cent in thick fog。 As mentioned above, the results from Camp Al on the Penny Icecap are not completely representative of the conditions lower on the icecap, and on the outflowing glaciers. The importance of radiation for the icecap as a whole must be less than the 61.3 per cent calculated for the highest dome. The convectional and conductional process must be considerably more important in ablation at lower altitudes, as there the fog frequency was lower and air temperatures higher than at the highest dome. Condensation would lose some of its impor tance at lower altitudes。

\section{COMPARISON WITH OTHER INVESTIGATIONS}

Wallen ${ }^{22}$ has summarized the results of the pioneer investigations around the northernmost Atlantic。 His Table 53 contains results, for August, of investigations in West Spitsbergen, North East Land, East Greenland, Iceland and Sweden. Ahlmann ${ }^{23}$ has reproduced Wallen's table and added results from an Alpine glacier。

22 Ibido, pp. 632-34。

23 Ahlmann, op, cito, po6. 
In the following table a similar comparison is made of the importance of various factors in the ablation on different glaciers, using the values given by Sverdrup, 24 Eriksson, 25 Ahlmann and Thorarinsson, 26 Wallen, 27 and Ward and Orvig. 28

TABLF: 45

PERCENTAGE IMPORTANCE OF DIFFERENT FACTORS IN ABLATION

Position \& Radia- Convec. \& Conden-

\begin{tabular}{|c|c|c|c|c|c|}
\hline Glacier \& Year & Elevatio & tion & Conduc & sation & Surface \\
\hline $\begin{array}{l}\text { Isachsen's } \\
\text { Plateau } \\
26 / 6-15 / 8,1934\end{array}$ & $\begin{array}{l}79009 \cdot \mathrm{N} \\
12056 \mathrm{E} \\
870 \mathrm{~m} . \\
\end{array}$ & 55.9 & 29.4 & 14.7 & Snow \\
\hline $\begin{array}{l}\text { Sveanor } \\
30 / 6-6 / 8,1931\end{array}$ & $\begin{array}{l}790561 \mathrm{~N} \\
18018^{\circ} \mathrm{E} \\
5 \mathrm{~m} .\end{array}$ & 23.9 & 58.5 & 17.6 & $\begin{array}{l}\text { Isolated } \\
\text { snow field }\end{array}$ \\
\hline $\begin{array}{l}\text { 14th of July } \\
\text { Glacier } \\
31 / 5-31 / 8,1934\end{array}$ & $\begin{array}{l}790001 \mathrm{~N} \\
120-\mathrm{E} \\
600 \mathrm{~m} .\end{array}$ & 47 & $\begin{array}{l}53+ \\
\text { cond. }\end{array}$ & -- & $\begin{array}{l}\text { Snow, ice } \\
\text { in August }\end{array}$ \\
\hline $\begin{array}{l}\text { Froya Glacier } \\
1 / 8-18 / 8,1939\end{array}$ & $\begin{array}{l}74024 \mathrm{~N} \\
20050 ! \mathrm{W} \\
453 \mathrm{mo}\end{array}$ & 8.2 & 83.4 & 8.4 & Snow \\
\hline $\begin{array}{l}\text { Hoffellsjökuil } \\
\text { April-October, } \\
1936\end{array}$ & $\begin{array}{r}64030 \mathrm{~N} \\
15^{\circ} 30 \mathrm{~W} \\
<1000 \mathrm{~m} . \\
\end{array}$ & 14 & $\begin{array}{l}86+ \\
\text { cond. }\end{array}$ & - & Ice \\
\hline $\begin{array}{l}\text { Karsa Glacier } \\
\text { August (1942- } \\
\text { 1948) }\end{array}$ & $\begin{array}{r}68020^{\prime} \mathrm{N} \\
18020^{\prime} \mathrm{E} \\
<1100 \mathrm{~m} . \\
\end{array}$ & 55 & 29 & 16 & Ice \\
\hline$--n-$ & $>-1100 \mathrm{~m}$. & 32 & 44 & 24 & Snow \\
\hline $\begin{array}{l}\text { Vernagtferner } \\
\text { (Alps), } 1950 \\
\text { li days in Aug. }\end{array}$ & $\begin{array}{l}46050 \mathrm{~N} \\
10045^{\circ} \mathrm{E} \\
3000 \mathrm{~m} .\end{array}$ & 81 & 15 & 3.5 & Ice \\
\hline $\begin{array}{l}\text { Barnes Icecap } \\
25 / 6-4 / 8,1950\end{array}$ & $\begin{array}{l}69^{\circ} 43^{\circ} \mathrm{N} \\
72013 \cdot \mathrm{W} \\
866 \mathrm{~m} .\end{array}$ & 67.7 & $\begin{array}{l}32.3 t \\
\text { cond. }\end{array}$ & - & $\begin{array}{l}\text { Snow (37days) } \\
\text { Ice (4days) }\end{array}$ \\
\hline $\begin{array}{l}\text { Penny Icecap } \\
13 / 7-26 / 7,1953\end{array}$ & $\begin{array}{l}66059 \mathrm{~N} \\
65^{\circ} 28 \mathrm{~W} \\
2050 \mathrm{~m} .\end{array}$ & 61.3 & 8.8 & 29.9 & Snow \\
\hline
\end{tabular}

24 H. U. Sverdrup, "The Ablation on Isachsen's Plateau and on the Fourteenth of July Glacier in Relation to Radiation and Meteorological Conditions," Geografiska Annaler, Vol. 17, Ht. 3-4, 1935 , p. 149 , p. 155 , p. 164 .

$25,26,27$ and 28: please see next page. 
It must be borne in mind that these values do not cover the same periods, and that therefore a direct comparison of the different locations can only have a limited value. However, Wallen's table contains the results of August observations; on both the Baffin Island icecara the ablation season was over before the middle of August。

It is not surprising, in view of the similar climatological conditions, that the results from Isachsen's Plateau and the Barnes and Penny Icecaps show so many similarities. The radiation is somewhat more important in Baffin Island than in Spitsbergen due to the lower latitude. The Karsa Glacier, although situated in a latitude between that of the Barnes and Penny Icecaps, shows somewhat less radiation importance, because it is of the temperate type and situated in a naritime climate。

The small amount of convection on the Penny Icecap is due to the low air temperatures. In this respect the opposite is found on the Froya Glacier and on Hoffellsjökull (Iceland), which are quite similar. Those glaciers are situated at low altitudes close to the sea, where sumer air temperatures are relatively

25 B。 E。 Eriksson, "Meteorological Records and the Ablation on the Froba Glacier in Relation to Radiation and Meteorological Conditions," Geografiska Annaler, Vol. 24, Ht. 1-2, 1942, p.39。

$26 \mathrm{H}$ 。 W: son Ahlmann and S. Thorarinsson, "Scientific Results of the Swedish-Icelandic Investigations 1936-37-38, Chapter $\mathrm{V}:$ Ablation," Geografiska Annaler, Vol。20, Ht. 3-4, 1938, p.226.

27 Wallen, op。cito, po633。

$28 \mathrm{~W}$. H. Ward and So Orvig, "The Heat Exchange at the Surface of the Barnes Ice Cap during the Ablation Period," The Journal of Glaciology, Vol。2, No。13, 1953, pp。166-67. 
high. More important on the Froya Glacier, however, is the fact that, in clear weather, the radiation from the snow surface was so great that the sum of radiated heat was negative, resulting in ablation mainly by convection. 29 The radiation actually increased in importance in cloudy weat':er. Etienne ${ }^{30}$ also found in West Greenland $\left(66^{\circ} \mathrm{N}\right)$ that the sum of radiated heat over the glacier surface often was negative。

It is necessary, in a comparison of conditions in different areas, to remember the topographical factor, which is important in governing radiation and wind conditions. The topographical picture is the same on the two Baffin Island icecaps and Isachsen's Plateau, and the most noticeable difference in the meteorological factors in those three locations is the very high condensation on the Penny Icecap. This is caused by the altitude and consequent low air temperature, resulting in fog and a reduced importance of convection。

Near the end of the ablation season the importance of the different factors will depend on a glacier's location. Near the coast, at low altitude, the convection will continue even after the radiation term becomes negative, but inland at higher altitudes the convection term will not increase in importance, and the radiation is important till the end of the season, as observed in Baffin Island. The season in Baffin Island terminated rather earlier than

29 Eriksson, 10c。cit.

30 E。 Etienne, cited by Eriksson, Ibid., p. 40。 
that in other investigated localities.

Although no previous research has been done on the glaciology of the Baffin Island icecaps, it seems safe to assume that conditions in the higher parts cannot have become more favourable for ablation in recent decades. The upper parts of the Penny Icecap are still in a healthy state, and the cause for the recent rapid wasting of the outflowing glaciers, as observed in the Pangnirtung Pass, must be increased ablation due to increased transfer of heat from the air. This is the most important factor at low levels, and it is caused by either increased air temperatures during the ablation season, or by a longer season, or by a como bination of these two factors. This could be caused by stronger and more persistent southerly winds, or by a reduction in frequency of northerly winds. It is probable that Baffin Island lies outside the area affected by the recent increased southward transport of air in the Greenland-Labrador - Newfoundland area (cf。p。165)。 Because of the altitude of the Penny Icecap the results of these ablation period studies are probably indicative of the conditions in high-polar regions。 
CHAPTER VIII

SUMIIARY AND CONCLUSIONS

\section{I。 SUMMARY}

The thesis contains the iesults of meteorological obsero vations carried out during the summer of 1953 on the Penny Icecap, and many references to similar observations on the Barnes Icecap in 1950. The weather in the Cumberland Peninsula area during the budget year 1952-53 is discussed, and an account is given of the radiation and ablation measurements. The heat exchange at the icecap surface is discussed, and the dependence of ablation on different meteorological factors is studied and compared with other regions.

\section{THE BUDGET YEAR 1952-53}

Surface data (average temperature, precipitation, wind and cloudiness) from Padloping Island have been compared with the values for the summer months of 1953. The months of June and August were only slightly colder than the ten-year average: July was exactly normal. May was warmer than the ten-year average. The summer had slightly more precipitation than the average over a longer period, and about average amounts of northerly winds. The southerly winds were considerably more frequent than in an average summer. Wind speeds were very close to normal, as was the cloudiness. 
The winter snowfall (1952-1953) at Padloping was heavier than the normal, but as the normal is for a short period (six years) it is reasonable to suppose that the accumulation on the Penny Icecap was close to the average.

\section{METEOROLOGICAL UBSERVATIONS}

Temperature. The mean daily temperature for the whole period of investigation was $19.7^{\circ}$; the absolute maximum was $38.5^{\circ}$ and the absolute minimum was $13.5^{\circ}$.

The average difference in temperature between Base Camp and the icecap was 17 degrees $F_{0}$ o $i_{0} e_{0}, 0.6$ degrees $\mathrm{C} / 100$ meters, or the same as the mean lapse rate of the free atmosphere.

The temperature increased with height above the icecap surface in only 17 per cent of all observations, and a straight drop in temperature with height was recorded in 39 per cent of all observations. The coldest period had the most unstable conditions, and the Penny Icecap stands out as an icecap with a frequently unstable temperature distribution above the surface。

The frequency distribution of temperatures above the surface on the Penny Icecap shows different characteristics from those of the Barnes Icecap and Isachsen's Plateau. On the Penny Icecap the maximum frequency fell in the interval $24.1-26.0^{\circ}$, several degrees below the freezing point. There was no direct relation between wind direction and temperature on the Penny Icecap。 
Humidity. The humidity measurements were not satisfactory, mainly because it was difficult to measure humidity at air temperatures near or below the freezing point. Supersaturation was frequently experienced on the Penny Icecap, with low temperatures and fog. The air was saturatcu to the highest level during most of the season. No certain correlation could be found between mean daily temperature and mean daily relative humidity.

Wind. No local factors influenced the wind, and the direction at different levels above the surface corresponded at all times. More than one third of the time had southwest wind. There was little difference in the wind speeds from the different directions. The average wind speed for the whole period was 9.8 $\mathrm{mph}$, which is relatively low, considering the altitude. The wind speeds were almost identical to those observed on the Barnes Icecap in 1950. More than half of all observations gave wind speeds between two and ten $\mathrm{mph}$.

Pressure. The wind very closely followed the changes in pressure; the mean pressure at the station was found to be 22.86 inches. Several frontal systems passed over the region during the summer, giving strong winds and heavy precipitation.

Clouds, cloudiness and fog. The observations of cloud conditions on the Penny Icecap were often hindered by the frequent fog at the station. Of all cloud observations 71 per cent showed fog or.St-forms; otherwise numerous forms were observed. 53 per 
cent of all observations had completely overcast sky. The average cloudiness for the whole period was $7.7 / 10$. The northwest winds were usually associated with the clearest weather, the southeast winds were usually associated with overcast conditions. The probability of fog was very uniform throughout the periocis the average probability was 0.61 , and fog was prevalent with wind from all directions.

\section{RADIATION MEASUREMENTS}

Sunshine. The total amount of sunshine for the eighty one days was 467 hours, this being only 26 per cent of the maximum possible. The high frequency of fog was responsible for the low value. Twenty-five days, or nearly 31 per cent of the time, had no sunshine. The mean daily temperature was often lower on days with many hours of sunshine than on days with overcast weather, the reason being the lower minimum temperatures on clear nights.

Incoming radiation. Two actinographs were used in recording total incoming short-wave radiation. The results were slightly different for the two instruments, and the average value for each day has been calculated. The ratio $I_{10} / I_{0}$ was considerably higher on the Penny Icecap than on the Karsa Glacier, in about the same latitude. The explanation is the frequent fog on the Penny Icecap, when the sky was often reported overcast, in spite of the fact that there may have been no middle or high cloud. The high values of incoming radiation are reasonable when 
compared with other observations in high latitudes.

Albedo. On the Fenny Icecap albedo measurements were carried out by measuring simultaneously the incoming and reflected radiation by two specially const, ucted radiometers. The albedo measurements gave good agreement with other investigations。

Outgoing radiation. Observations of the net radiative flux were made, but these were only spot measurements, and a continuous recording is not available. The outgoing (long-wave) radiation has been adopted from previous research in other regions.

\section{ABLATION MEASUREMENTS}

The Penny Icecap is different from its northern neighbours. It lies at a higher altitude and therefore reaches above the local firn line. The firn line was found to be at about 5100 feet. At Camp Al typical firn was found below the current settled snow of about three to four foot thickness. Below forty-three feet there was almost entirely solid ice. The ablation season was short and interrupted, and accumulation took place throughout the summer at the altitude of the icecap campo The temperate and most of the sub-polar glaciers have air temperatures above the freezing point in the ablation season over the whole glacier. Such was the case on the Barnes Icecap. If a sub-polar glacier or icecap is situated at a high altitude, the conditions may become similar to those of a polar glacier where the air temperature may never rise above the freezing point. The ablation in 
the accumulation area becomes very small. Such was the case on the Penny Icecap. The ablation on the highest dome took place in three short continuous periods and in one intermittent period, totalling 10-15 cms。 of water。 The 1952-53 accumulation, equal to the ablation, at the equilibrium line was $40 \mathrm{cms}$ of water.

Classification。 The values of accumulation ( = ablation) at the equilibrium line, and the altitude of that line, placed the Barnes Icecap close to the icecaps of Spitsbergen in a general classification of glaciers a direct result of the relatively similar meteorological conditions.

On the Penny Icecap the equilibrium line was found to be at 1380 meters.

In 1950 it was found that the Barnes Icecap is nearly stationary, and not receding. In the Penny Icecap region the outflowing glaciers are noticeably retreating, but air temperatures in summer are too low to allow a great deal of ablation in the higher parts。

THE HEAT EXCHANGE

On the Barnes Icecap the total amount of heat received during the ablation period was estimated because the observations were deficient in precise measurements of radiation.

For the Penny Icecap Sverdrup's theories have been used, with modifications where necessary according to the results of the meteorological observations. As a first approximation it was 
assumed that the upper layers of snow had a temperature of $0^{\circ} \mathrm{C}$ during the periods of ablation, although the temperature conditions in effect were quite complex during the first and second periods.

\section{ABLATION AND METFORULOGICAL FACTORS}

There are two factors in the ablation equation which are difficult to obtain with satisfactory accuracy: the ablation and the vertical gradient of vapour pressure. With due consideration to these uncertain values, and to the heat loss in the underlying firn, a reasonable agreement has been obtained between the theoretical and observed ablation for all three main melting periods. Evaporation was insignificant because of the high moisture content of the air. The heat for ablation was mainly supplied by radiation (61.3 per cent)。 Next in importance was condensation (29.9 per cent); convection and conduction supplied only 8.8 per cent. In a comparison with investigations in other areas it is found that the results from Isachsen's Plateau (West Spitsbergen) and the Baffin Island icecaps show many similarities. The importance of radiation is somewhat greater in Baffin Island, due to the lower latitude。

\section{II。 CONCLUSIONS}

THE BUDGET YEAR 1952-1953

From the available data it is safe to assume that the summer weather in 1953 was very close to normal, and on the icecap 
the summer's ablation was close to an average season's. The assumption that the winter accumulation on the icecap was close to the average, combined with the normal conditions during the ablation season, must have resulted in a typical budget year. The results of the investigaitions on the Penny Icecap in 1953 can therefore be taken as a true picture of the average conditions.

\section{METEOROLOGICAL OBSERVATIONS}

Temperature. Only a slight tendency to a stabilizing effect by the melting snow surface was observed. On the whole the daily range of temperature was dependent on cloud conditions and wind direction more than on the surface snow conditions.

The difference in temperatures between Padloping and Base Camp in Pangnirtung Pass ( 1300 feet) was very small, the inland location of Base Camp being counteracted by the higher altitude.

A temperature gradient of 0.6 degrees $C / 100$ meters was found both in 1950 and in 1953, indicating a uniform value over large areas in Baffin Island。

The temperature distribution above the surface on the Penny Icecap was, on the whole, an unstable one. The more frequent unstable lapse rates were experienced in May and early June. On the Barnes Icecap the temperature distribution was, in most cases, a very stable one, indicating that heat must have been transported from the air to the surface during most of the ablation season. This was not the case on the Penny Icecap. The Barnes Icecap acts as a temperature stabilizer; it endeavours to lower the air 
temperature to $32^{\circ}$, its own temperature in the ablation season. On the Penny Icecap the supply of heat to the icecap by way of convection is small. Both temperature and wind is controlled by the general pressure distribution in the area; an indication of a purely geographic contrci of the temperature-wind relationship was not observed. The importance of unperiodic changes in the temperature of the air masses is greater over snow surfaces at high altitudes (the Penny Icecap) than over snow and ice surfaces at lower altitudes (the Barnes Icecap and Isachsen's Plateau). Over the lower icecaps the stratification is also stable, on the whole, even on days with only below-freezing temperatures. Over the surface of a high-Iying icecap it is to be expected that the cold days have unstable conditions, and only the warmest periods will show stable conditions. Regardless of altitude, it seems that the icecaps and glaciers in Baffin Island exercise very little control over the climate of the surrounding land.

Pressure. Several frontal systems passed over the region, and it seems that well developed frontal systems may form or travel farther north than has generally been recognized. The region of the Penny Icecap is frequently influenced by the northern part of the low pressure systems.

\section{RADIATION MEASUREMENTS}

Sunshine. The icecaps (especially low-lying ones) act as temperature stabilizers in the period of ablation. On clear days the temperature will remain relatively low, on clear nights the 
long wave radiation will cool the air. On overcast days the heating of the air during the daytime is less, but the cooling at night is also less, the result being a smaller diurnal variation of temperature. The heating of the air on sunny days takes place over the snow free land surounding the icecaps. The temperatures over the ice itself are dependent on the duration of sunshine, the ratio of snow covered to snow free land, and on the distance the air has travelled over the icecap surface.

\section{Incoming radiation. The ratio $I_{10} / I_{0}$ was higher on the} Penny Icecap than anywhere else in the Arctic where similar investigations have been undertaken. The reason must be the impos sibility of observing cloud conditions through the thick fog, and probably multiple reflection between the snow surface and the fog。 It is also probable that the clouds overhead were thinner than those experienced in other (lower) locations. More accurate observations of the high and middle cloud would almost certainly have resulted in a smaller value for $I_{10} / I_{0}$.

\section{ABLATION MEASUREMENTS}

Classification. Ahlmann ${ }^{1}$ has suggested a classification of glaciers according to the accumulation (: ablation) at the firn line and the altitude of the firn line.

"Arctic-continental" glaciers, according to Ahlmann, should have an accumulation at the firn line of $0-50 \mathrm{cms}$ of water, 
and "arctic-maritime" glaciers should have an accumulation of 50-100 cms of water and an altitude of the firn line of 0-750 meters above sea level。 More pronouncedly continental climates are characterized by less accumulation. The Barnes Icecap must be placed on the dividing in ne between "arctic-continental" and "arctic-maritime" glaciers. The values for the Penny Icecap place it among the glaciers characterized by small precipitation and consequently high firn lines. Studies on the Barnes Icecap did not make it possible to state that the general "warming of the Arctic" is making itself felt in that part of Baffin Island. In the region of the Penny Icecap a general increase in the extent of glaciation at least 150-200 years ago has been followed by a retreat which began about 50 years ago, and which is still notably in progress. It is probable, but not certain, that the Penny Icecap proper regularly has a negative regime at the present time. A very marked increase in air temperatures would be necessary before a shrinkage of the present icecap could take place at the altitude of the highest parts. However, a prolongation of the ablation season and higher summer temperatures would be noticed in increased ablation in the lower altitudes。

\section{ABLATION AND METEOROLOGICAL FACTORS}

The relative significance of radiation, convection and conduction, and condensation in ablation varies not only with altitude and the general character of the climate, but also with the latitude, and with the season. 
Nothing can be said about the variation with time of the heat supply for ablation, as the season spanned over only thirteen days. The icecap camp was located on the highest dome; the results are therefore not completely representative of conditions lower on the icecap, and on the outtiowir glaciers. The importance of radiation for the icecap as a whole must be less than 61 per cent. The convectional and conductional processes must be considerably more important in ablation at lower altitudes than near the top。 Condensation would lose some of its importance at lower levels. Near the end of the ablation season the importance of the different factors will depend on a glacier's location. In the position of the Baffin Island icecaps, inland at relatively high altitudes, the convection term will not increase in importance towards the end, and the radiation continues to be important till the end of the season. The ablation season in Baffin Island terminates rather earlier than that in other regions investigated。

It seems safe to assume that conditions in the higher parts of the Baffin Island icecaps cannot have become more favourable for ablation in recent decades. The upper parts of the Penny Icecap are still in a healthy state, and the cause for the recent rapid wasting away of the outflowing glaciers must be increased ablation due to increased transfer of heat from the air. It may be caused by either increased air temperatures during the ablation season, or by a longer ablation season, or by a combination of these two factors. It is probable that Baffin Island lies outside the area affected by the recent increased southward transport of air in 
the Greeland-Labrador $\sim$ Newfoundland area。

The results of the observations on the Penny Icecap may be assumed to be indicative of conditions in high-polar regions, because of the altitude of the iccuap station. 
TABLES $I$ - XIII 


\section{TABLE I}

MEAN TEMPERATURE FOR EACH DAY OF INVESTIGATION

Three feet above the surface

\begin{tabular}{|c|c|c|c|c|}
\hline Date & May & Juné & July & August \\
\hline $\begin{array}{l}1 \\
2 \\
3 \\
4 \\
5 \\
6 \\
7 \\
8 \\
9 \\
10 \\
11 \\
12 \\
13 \\
14 \\
15 \\
16 \\
17 \\
18 \\
19 \\
20 \\
21 \\
22 \\
23 \\
24 \\
25 \\
26 \\
27 \\
28 \\
29 \\
30 \\
31\end{array}$ & $\begin{array}{r}22.4 \\
16.0 \\
14.7 \\
18.1 \\
21.5 \\
18.9 \\
9.7 \\
-9.4 \\
-2.5 \\
5.6 \\
9.1\end{array}$ & $\begin{array}{r}12.2 \\
5.3 \\
5.2 \\
16.7 \\
20.1 \\
18.9 \\
17.5 \\
13.7 \\
11.0 \\
11.0 \\
8.8 \\
3.1 \\
15.2 \\
11.9 \\
8.4 \\
7.7 \\
9.7 \\
11.8 \\
13.1 \\
11.5 \\
12.3 \\
11.1 \\
15.0 \\
15.9 \\
27.2 \\
26.5 \\
28.7 \\
27.1 \\
23.5 \\
25.2\end{array}$ & $\begin{array}{l}25.0 \\
26.6 \\
26.7 \\
24.1 \\
20.5 \\
23.3 \\
22.1 \\
24.6 \\
26.0 \\
24.9 \\
23.8 \\
22.2 \\
27.3 \\
31.4 \\
33.1 \\
13.1 \\
14.6 \\
20.9 \\
29.1 \\
33.7 \\
21.9 \\
19.1 \\
26.4 \\
35.6 \\
35.6 \\
30.1 \\
27.1 \\
26.7 \\
29.6 \\
28.0 \\
25.9\end{array}$ & $\begin{array}{l}25.6 \\
24.6 \\
23.2 \\
25.7 \\
30.7 \\
30.3 \\
27.2 \\
21.2 \\
22.0\end{array}$ \\
\hline
\end{tabular}


TABLE II

FIVE-DAY RUNNING MEANS OF MEAN DAILY TEMPERATURE

Three feet above the surface

\begin{tabular}{lrrrr} 
Date & May & June & July & August \\
\hline 1 & & 7.5 & 25.4 & 25.5 \\
2 & & 9.7 & 25.5 & 25.0 \\
3 & & 11.9 & 24.6 & 26.0 \\
4 & 13.2 & 24.2 & 26.9 \\
5 & & 15.7 & 23.3 & 27.4 \\
6 & 17.4 & 22.9 & 27.0 \\
7 & & 16.2 & 23.3 & 26.3 \\
8 & & 14.4 & 24.2 & \\
9 & & 12.4 & 24.3 & \\
10 & & 9.5 & 24.3 & \\
11 & & 9.8 & 24.8 & \\
12 & & 10.0 & 25.9 & \\
13 & 9.5 & 27.6 & \\
14 & & 9.3 & 25.4 & \\
15 & & 10.6 & 23.9 & \\
16 & & 9.9 & 22.6 & \\
17 & & 10.1 & 22.2 & \\
18 & & 10.8 & 22.3 & \\
19 & & 11.7 & 24.0 & \\
20 & & 12.0 & 24.9 & \\
21 & & 12.6 & 26.0 & \\
22 & & 13.2 & 27.3 & \\
23 & & 16.3 & 27.7 & \\
24 & 18.5 & 19.1 & 29.4 & \\
25 & 17.8 & 22.7 & 31.0 & \\
26 & 16.6 & 25.1 & 31.0 & \\
27 & 11.8 & 26.6 & 29.8 & \\
28 & 7.6 & 26.2 & 28.3 & \\
29 & 4.5 & 25.9 & 27.5 & \\
30 & 2.5 & 25.5 & 27.2 & \\
31 & 3.0 & & 26.7 & \\
& 5.9 & & & \\
& & & &
\end{tabular}


TABLE III

DAILY MAXIMUM AND NINIMUM TEMPERATURE

Three feet above the surface

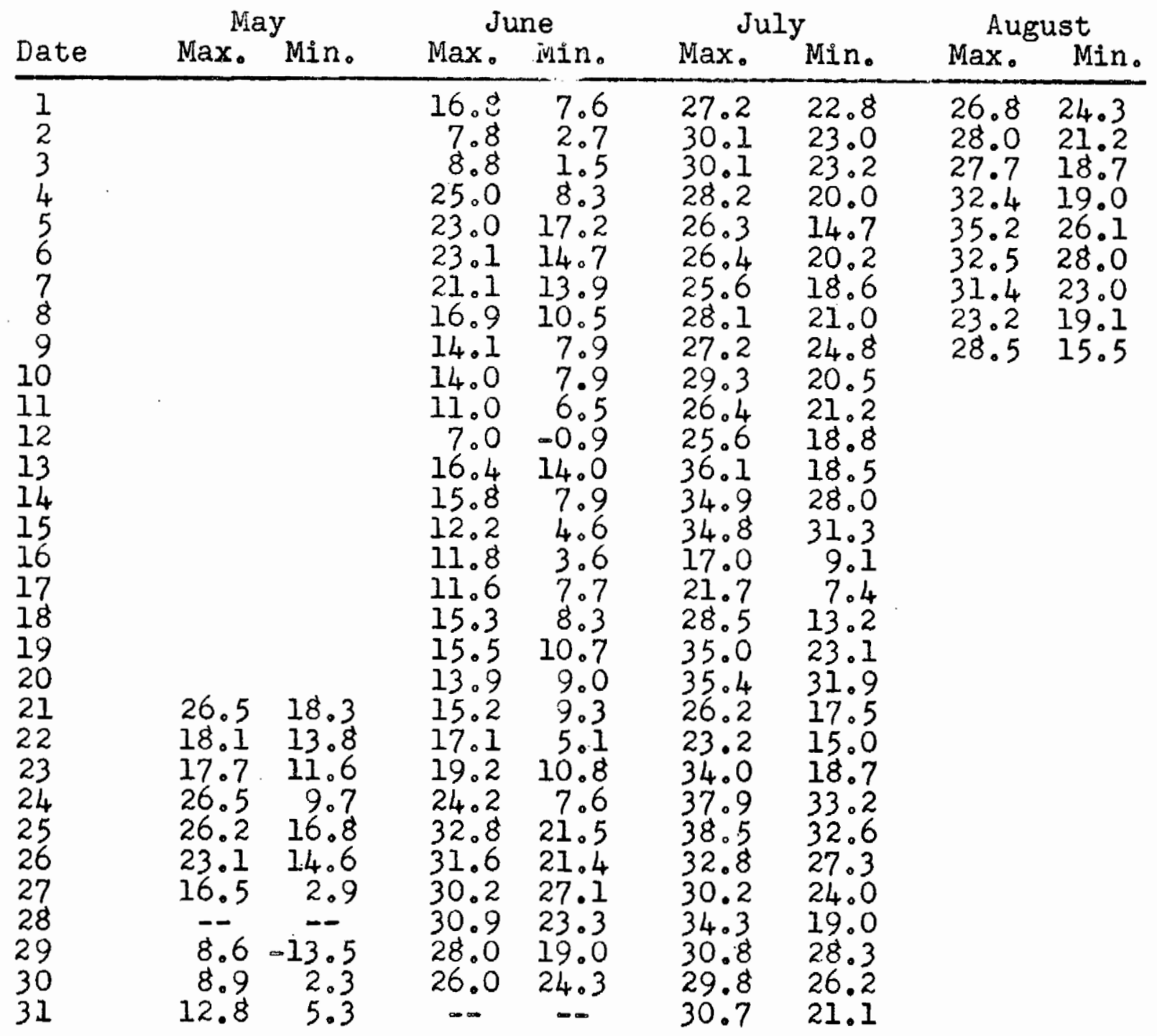


TABLE IV

DAILY RANGE OF TEMPERATURE

Three feet above the surface

\begin{tabular}{|c|c|c|c|c|}
\hline Date & May & Tine & July & August \\
\hline $\begin{array}{l}1 \\
2 \\
3 \\
4 \\
5 \\
6 \\
7 \\
8 \\
9 \\
10 \\
11 \\
12 \\
13 \\
14 \\
15 \\
16 \\
17 \\
18 \\
19 \\
20 \\
21 \\
22 \\
23 \\
24 \\
25 \\
26 \\
27 \\
28 \\
29 \\
30 \\
31\end{array}$ & $\begin{array}{r}8.2 \\
4.3 \\
6.1 \\
16.8 \\
9.4 \\
8.5 \\
13.6 \\
22.1 \\
6.6 \\
7.5\end{array}$ & $\begin{array}{r}9.2 \\
5.1 \\
7.3 \\
16.7 \\
5.8 \\
8.4 \\
7.2 \\
6.4 \\
6.2 \\
6.1 \\
4.5 \\
7.9 \\
2.4 \\
7.9 \\
7.6 \\
8.2 \\
3.9 \\
7.0 \\
4.8 \\
4.9 \\
5.9 \\
12.0 \\
8.4 \\
16.6 \\
11.3 \\
10.2 \\
3.1 \\
7.6 \\
9.0 \\
1.7\end{array}$ & $\begin{array}{r}4.4 \\
7.1 \\
6.9 \\
8.2 \\
11.6 \\
6.2 \\
7.0 \\
7.1 \\
2.4 \\
8.8 \\
5.2 \\
6.8 \\
17.6 \\
6.9 \\
3.5 \\
7.9 \\
14.3 \\
15.3 \\
11.9 \\
3.5 \\
8.7 \\
8.2 \\
15.3 \\
4.7 \\
5.9 \\
5.5 \\
6.2 \\
15.3 \\
2.5 \\
3.6 \\
9.6\end{array}$ & $\begin{array}{r}2.5 \\
6.8 \\
9.0 \\
13.4 \\
9.1 \\
4.5 \\
8.4 \\
4.1 \\
13.0\end{array}$ \\
\hline $\begin{array}{l}\text { Mear } \\
\text { ran }\end{array}$ & 10.3 & 7.4 & 8.0 & 7.9 \\
\hline
\end{tabular}


TABLE V

MEAN DAYTIME TEMPERATURE AT THREE LEVELS

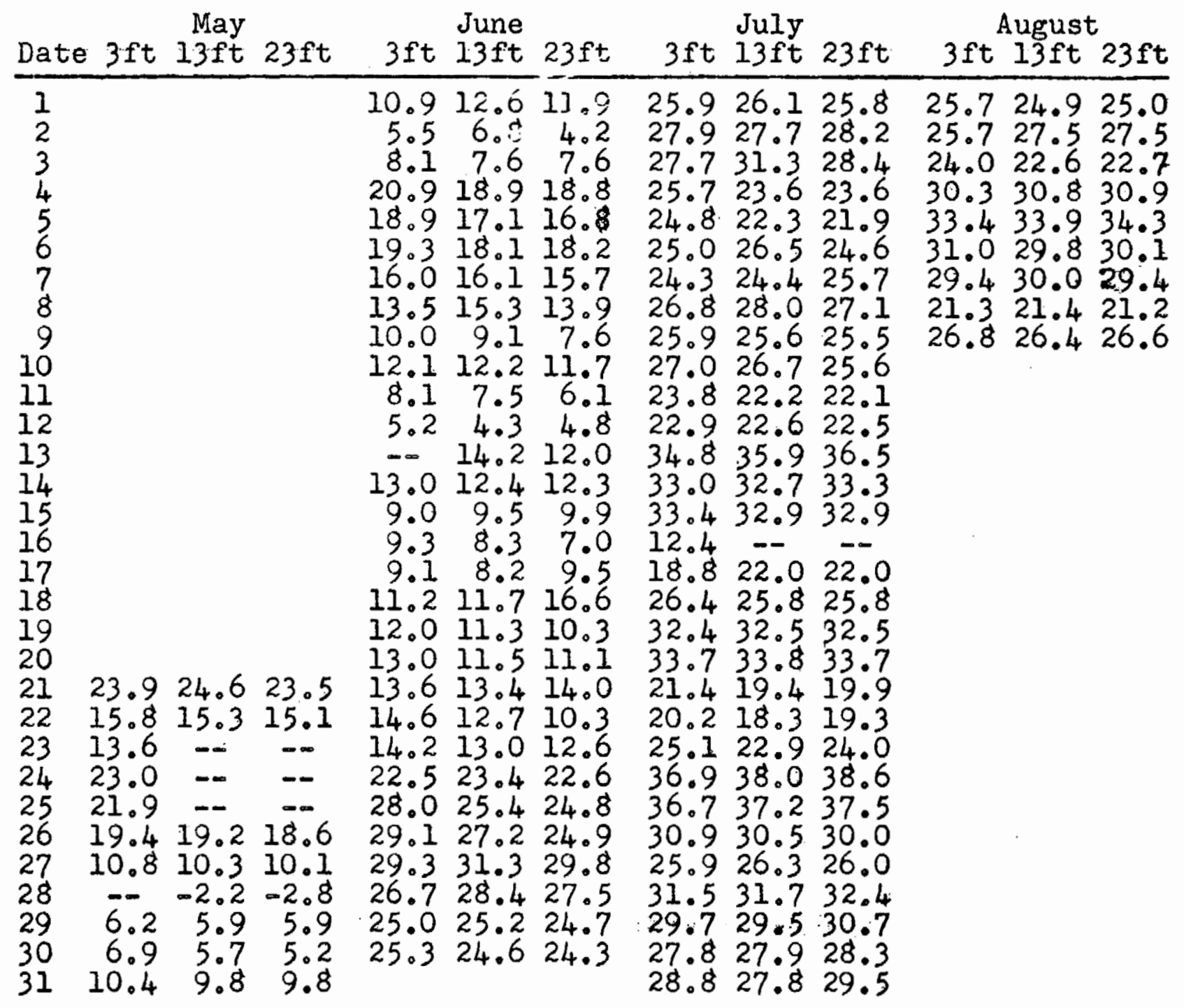


TABLE VI

FREQUENCY OF DIFFERENT TEMPERATURE

INTERVALS AT THE THREE LEVELS IN PERCENTAGES

OF THE TOTAL NUMBER OF MEASUREMENTS

(Daytime Temperatures from 0800 to 2000)

\begin{tabular}{|c|c|c|c|c|c|c|}
\hline Interval & $\begin{array}{l}\text { no. of } \\
\text { cases }\end{array}$ & $\begin{array}{r}3 \mathrm{ft} 。 \\
\% \\
\end{array}$ & $\begin{array}{l}\text { no. of } \\
\text { cases }\end{array}$ & $\begin{array}{r}13 \mathrm{ft} . \\
\%\end{array}$ & $\begin{array}{l}\text { no. of } \\
\text { cases }\end{array}$ & $23 \mathrm{ft}$. \\
\hline 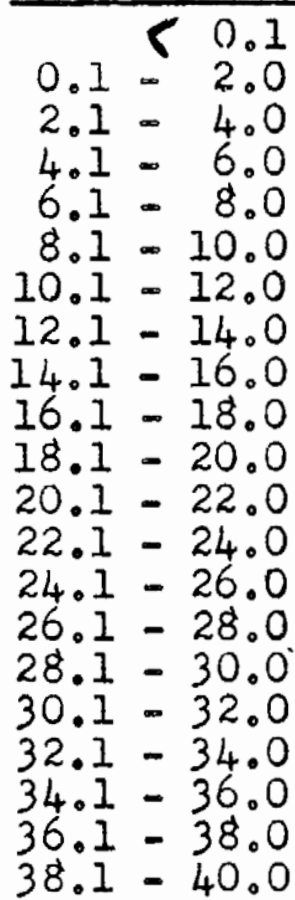 & $\begin{array}{r}0 \\
0 \\
3 \\
5 \\
18 \\
19 \\
19 \\
26 \\
19 \\
15 \\
21 \\
30 \\
35 \\
67 \\
61 \\
44 \\
29 \\
24 \\
15 \\
13 \\
0\end{array}$ & $\begin{array}{l}0 \\
0 \\
0.6 \\
1.1 \\
3.9 \\
4.1 \\
4.1 \\
5.6 \\
4.1 \\
3.2 \\
4.5 \\
6.5 \\
7.6 \\
14.5 \\
13.2 \\
9.5 \\
6.3 \\
5.2 \\
3.2 \\
2.8 \\
0\end{array}$ & $\begin{array}{l}3 \\
2 \\
0 \\
7 \\
15 \\
19 \\
13 \\
21 \\
15 \\
15 \\
20 \\
25 \\
32 \\
59 \\
45 \\
28 \\
31 \\
23 \\
17 \\
12 \\
6\end{array}$ & $\begin{array}{l}0.7 \\
0.5 \\
0 \\
1.7 \\
3.7 \\
4.7 \\
3.2 \\
5.1 \\
3.7 \\
3.7 \\
4.9 \\
6.1 \\
7.8 \\
14.5 \\
11.0 \\
6.9 \\
7.6 \\
5.6 \\
4.2 \\
2.9 \\
1.5\end{array}$ & $\begin{array}{l}3 \\
0 \\
4 \\
12 \\
13 \\
18 \\
13 \\
19 \\
14 \\
12 \\
20 \\
27 \\
35 \\
59 \\
40 \\
34 \\
28 \\
25 \\
15 \\
6 \\
10\end{array}$ & $\begin{array}{l}0.7 \\
0 \\
1.0 \\
2.9 \\
3.2 \\
4.4 \\
3.2 \\
4.7 \\
3.4 \\
2.9 \\
4.9 \\
6.6 \\
8.6 \\
14.5 \\
9.8 \\
8.4 \\
6.9 \\
6.2 \\
3.7 \\
1.5 \\
2.5\end{array}$ \\
\hline Total: & 463 & 100.0 & 408 & 100.0 & 407 & 100.0 \\
\hline
\end{tabular}


TABLE VII

MEAN VALUES OF TEMPERATURE AT TWO-HOURLY INTERVALS FROM 0800 TO 2000 AT THREE LEVELS

\begin{tabular}{lcccccc} 
Hour & \multicolumn{9}{c}{ May (1l days) } & June \\
& 3ft. & 13ft. & 23ft。 & 3ft. & 13ft. & 23ft. \\
\hline 0800 & 17.6 & 9.3 & 9.0 & 16.2 & 15.9 & 15.4 \\
1000 & 19.3 & 10.7 & 11.1 & 17.6 & 18.2 & 18.2 \\
1200 & 20.1 & 12.9 & 12.5 & 16.5 & 16.3 & 15.3 \\
1400 & 16.4 & 13.4 & 12.7 & 16.6 & 15.9 & 14.9 \\
1600 & 14.9 & $-\infty$ & 11.5 & 18.3 & 18.1 & 17.4 \\
1800 & 14.8 & $\infty$ & $-\infty$ & 17.6 & 16.7 & 16.6 \\
2000 & 13.0 & 11.4 & 11.1 & 14.6 & 14.5 & 14.5
\end{tabular}

\begin{tabular}{|c|c|c|c|c|c|c|}
\hline Hour & $3 \mathrm{ft}$. & $\begin{array}{l}\text { July } \\
13 \mathrm{ft} \text {. }\end{array}$ & $23 \mathrm{ft}$. & $3 \mathrm{ft}$. & $\begin{array}{l}\text { ugust } \\
13 \mathrm{ft} \text {. }\end{array}$ & $\begin{array}{c}\text { days) } \\
23 \mathrm{ft} .\end{array}$ \\
\hline $\begin{array}{l}0800 \\
1000 \\
1200 \\
1400 \\
1600 \\
1800 \\
2000\end{array}$ & $\begin{array}{l}27.3 \\
28.1 \\
28.0 \\
28.0 \\
28.1 \\
27.1 \\
26.8\end{array}$ & $\begin{array}{l}26.8 \\
28.1 \\
28.4 \\
28.3 \\
28.2 \\
27.4 \\
27.5\end{array}$ & $\begin{array}{l}26.7 \\
28.6 \\
28.7 \\
28.1 \\
28.4 \\
27.4 \\
27.6\end{array}$ & $\begin{array}{l}27.2 \\
27.6 \\
27.8 \\
27.9 \\
27.9 \\
27.1 \\
26.8\end{array}$ & $\begin{array}{l}26.0 \\
26.3 \\
27.3 \\
27.9 \\
28.1 \\
27.1 \\
26.8\end{array}$ & $\begin{array}{l}26.3 \\
26.4 \\
27.1 \\
28.0 \\
28.0 \\
27.0 \\
27.1\end{array}$ \\
\hline
\end{tabular}


TABLE VIII

MEAN DAILY VALUES OF RELATIVE HUMIDITY AT THREE FEET

\begin{tabular}{|c|c|c|c|c|}
\hline Date & May & June & July & August \\
\hline 1 & & 92 & 100 & 100 \\
\hline 2 & & IUU & 100 & 97 \\
\hline 3 & & $9 \%$ & 69 & 82 \\
\hline 4 & & 99 & 81 & 73 \\
\hline 5 & & 100 & 93 & 97 \\
\hline 6 & & 100 & 98 & 98 \\
\hline 7 & & 100 & 100 & 78 \\
\hline 8 & & 97 & 99 & 97 \\
\hline 9 & & $\infty$ & 100 & 94 \\
\hline 10 & & 100 & 95 & \\
\hline 11 & & 100 & 100 & \\
\hline 12 & & 100 & 94 & \\
\hline 13 & & $=x-$ & 86 & \\
\hline 14 & & 100 & 91 & \\
\hline 15 & & 100 & 100 & \\
\hline 16 & & 100 & 100 & \\
\hline 17 & & 100 & 76 & \\
\hline 18 & & 100 & 68 & \\
\hline 19 & & 100 & 99 & \\
\hline 20 & & 100 & 100 & \\
\hline 21 & 96 & 100 & 100 & \\
\hline 22 & 99 & 98 & 100 & \\
\hline 23 & 91 & 100 & 99 & \\
\hline 24 & 100 & 77 & 99 & \\
\hline 25 & 56 & 58 & 100 & \\
\hline 26 & 54 & 56 & 100 & \\
\hline 27 & 87 & 75 & 100 & \\
\hline 28 & $=$ & 72 & 96 & \\
\hline 29 & 100 & 94 & 100 & \\
\hline 30 & 100 & 100 & 100 & \\
\hline 31 & 100 & & 99 & \\
\hline Mean: & 88.3 & 93.5 & 94.9 & 90.7 \\
\hline
\end{tabular}


TABLE IX

AVERAGE DAILY WIND SPEED ON THE ICECAP IN MPH

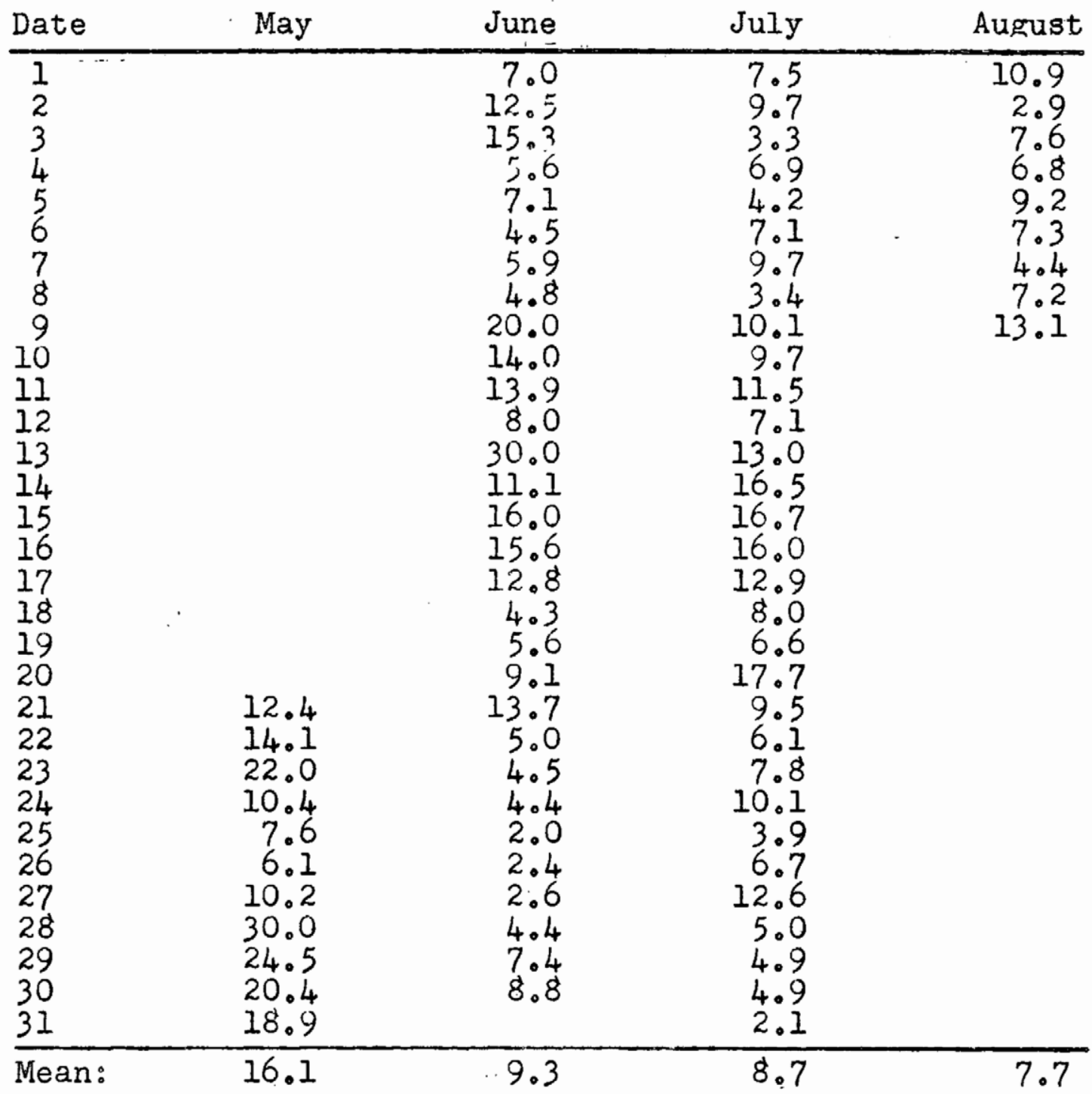


TABLE $X$

MEAN DAILY PRESSURE AT CAMP AI

\begin{tabular}{|c|c|c|c|c|}
\hline Date & May & June & July & August \\
\hline $\begin{array}{r}1 \\
2 \\
3 \\
4 \\
5 \\
6 \\
7 \\
8 \\
9 \\
10 \\
11 \\
12 \\
13 \\
14 \\
15 \\
16 \\
17 \\
18 \\
19 \\
20 \\
21 \\
22 \\
23 \\
24 \\
25 \\
26 \\
27 \\
28 \\
29 \\
30 \\
31\end{array}$ & $\begin{array}{l}22.96 \\
22.76 \\
22.76 \\
23.03 \\
23.12 \\
23.03 \\
22.83 \\
22.8 \\
22.82 \\
22.85\end{array}$ & $\begin{array}{l}23.01 \\
22.94 \\
22.81 \\
22.75 \\
22.73 \\
22.66 \\
22.57 \\
22.67 \\
22.66 \\
22.71 \\
22.67 \\
22.63 \\
22.67 \\
22.39 \\
22.46 \\
22.66 \\
22.74 \\
22.73 \\
22.74 \\
22.70 \\
22.77 \\
22.68 \\
22.81 \\
22.95 \\
23.90 \\
23.11 \\
23.09 \\
23.06 \\
23.01 \\
22.99\end{array}$ & $\begin{array}{l}23.12 \\
23.21 \\
23.21 \\
23.08 \\
22.95 \\
22.93 \\
22.95 \\
22.91 \\
22.88 \\
22.84 \\
22.99 \\
22.81 \\
23.12 \\
23.06 \\
22.89 \\
22.70 \\
22.86 \\
22.91 \\
22.83 \\
22.78 \\
22.64 \\
22.80 \\
22.92 \\
22.99 \\
22.897 \\
22.73 \\
22.73 \\
22.99 \\
22.997 \\
22.99 \\
22.998\end{array}$ & $\begin{array}{l}22.99 \\
23.03 \\
22.97 \\
23.01 \\
23.01 \\
22.87 \\
22.76 \\
22.74 \\
22.76\end{array}$ \\
\hline Mean: & 22.91 & 22.78 & 22.91 & 22.90 \\
\hline $\mathrm{mb} .:$ & 775.8 & 771.4 & 775.8 & 775.5 \\
\hline
\end{tabular}


TABLE XI

DURATION OF SUNSHINE

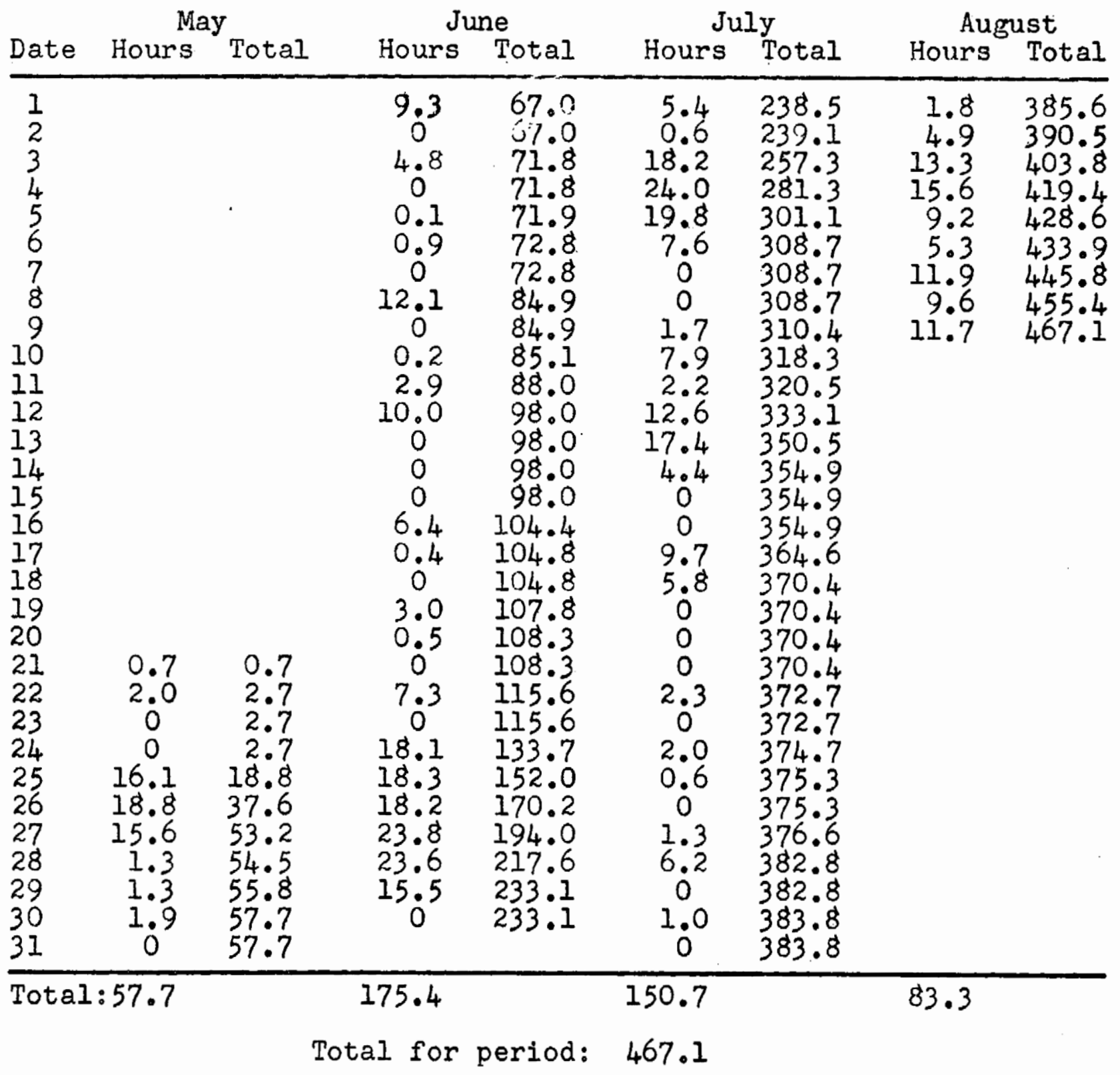


-225 -

TABLE XII

DAILY INCOMING RADIATION IN $\mathrm{cal} / \mathrm{cm}^{2}$

\begin{tabular}{ccccc} 
Date & May & June & July & August \\
\hline 1 & & 844 & 730 & 576 \\
2 & & 626 & 664 & 555 \\
3 & $7 j 2$ & 792 & 679 \\
4 & & 595 & 843 & 632 \\
5 & 601 & 911 & 594 \\
6 & & 648 & 792 & 527 \\
7 & 647 & 662 & 576 \\
8 & & 737 & 623 & 649 \\
9 & & 687 & 580 & \\
10 & & 699 & 621 & \\
11 & & 704 & 627 & \\
12 & & 738 & 756 & \\
13 & & 823 & -12 & \\
14 & & 697 & 544 & \\
15 & & 673 & 522 & \\
16 & & 822 & 677 & \\
17 & & 675 & 767 & \\
18 & & 664 & 603 & \\
19 & & 654 & 540 & \\
20 & & 719 & 384 & \\
21 & 663 & 501 & \\
22 & 479 & 842 & -5 & \\
23 & 623 & 723 & 477 & \\
24 & 603 & 877 & 406 & \\
25 & 504 & 761 & 409 & \\
26 & 845 & 738 & 335 & \\
27 & 778 & 812 & 498 & \\
28 & 767 & 828 & 386 & \\
29 & 776 & 661 & 438 & \\
30 & 616 & & 457 & \\
31 & 678 & & & \\
& 678 & & &
\end{tabular}


$-226=$

TABLE XIII

SNOW DEPTH IN INCHES

\begin{tabular}{|c|c|c|c|c|c|c|c|c|}
\hline \multirow[b]{2}{*}{ Date } & \multicolumn{2}{|c|}{ May } & \multicolumn{2}{|c|}{ June } & \multicolumn{2}{|c|}{ July } & \multicolumn{2}{|c|}{ August } \\
\hline & $\begin{array}{l}\text { Snow } \\
\text { Depth }\end{array}$ & Loss & $\begin{array}{l}\text { Snow } \\
\text { Depth }\end{array}$ & Loss & $\begin{array}{l}\text { Snow } \\
\text { Depth }\end{array}$ & Loss & $\begin{array}{l}\text { Snow } \\
\text { Depth }\end{array}$ & Loss \\
\hline $\begin{array}{l}1 \\
2 \\
3 \\
4 \\
5 \\
6 \\
7 \\
8 \\
9 \\
10 \\
11 \\
12 \\
13 \\
14 \\
15 \\
16 \\
17 \\
18 \\
19 \\
20 \\
21 \\
22 \\
23 \\
24 \\
25 \\
26 \\
27 \\
28 \\
29 \\
30\end{array}$ & $\begin{array}{cc}53 & 7 / 8 \\
53 & 6 / 8 \\
- & - \\
54 & 1 / 8 \\
-\infty \\
=- \\
-- \\
53 & 6 / 8 \\
53 & 4 / 8 \\
53 & 3 / 8\end{array}$ & $\begin{array}{r}2 / 8 \\
1 / 8 \\
-14 / 8\end{array}$ & $\begin{array}{cc}54 & 7 / 8 \\
56 & 6 / 8 \\
55 & 5 / 8 \\
56 & 1 / 8 \\
-\infty \\
57 & 1 / 8 \\
57 & 5 / 8 \\
56 & 7 / 8 \\
57 & 5 / 8 \\
58 & 4 / 8 \\
& -\infty \\
57 & 7 / 8 \\
61 & 2 / 8 \\
60 & 2 / 8 \\
57 & 3 / 8 \\
57 & 7 / 8 \\
59 & 5 / 8 \\
58 & 2 / 8 \\
58 & 5 / 8 \\
61 & 1 / 8 \\
61 & 1 / 8 \\
60 & 7 / 8 \\
60 & 7 / 8 \\
60 & 5 / 8 \\
60 & 1 / 8 \\
59 & 4 / 8 \\
59 & 2 / 8 \\
59 & 7 / 8\end{array}$ & 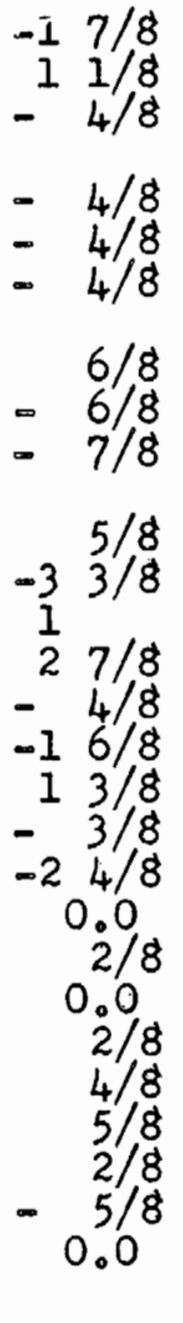 & $\begin{array}{ll}59 & 7 / 8 \\
59 & 7 / 8 \\
59 & 5 / 8 \\
59 & 2 / 8 \\
59 & 1 / 8 \\
58 & 7 / 8 \\
58 & 7 / 8 \\
59 & 1 / 8 \\
59 & 1 / 8 \\
59 & 3 / 8 \\
62 & 2 / 8 \\
60 & 6 / 8 \\
59 & 5 / 8 \\
58 & 7 / 8 \\
57 & 2 / 8 \\
59 & 1 / 8 \\
59 & \\
59 & \\
59 & 2 / 8 \\
56 & 6 / 8 \\
59 & 2 / 8 \\
59 & 4 / 8 \\
59 & \\
58 & 7 / 8 \\
56 & 4 / 8 \\
54 & 5 / 8 \\
56 & 7 / 8 \\
57 & 5 / 8 \\
56 & 3 / 8 \\
56 & 4 / 8 \\
55 & 7 / 8\end{array}$ & 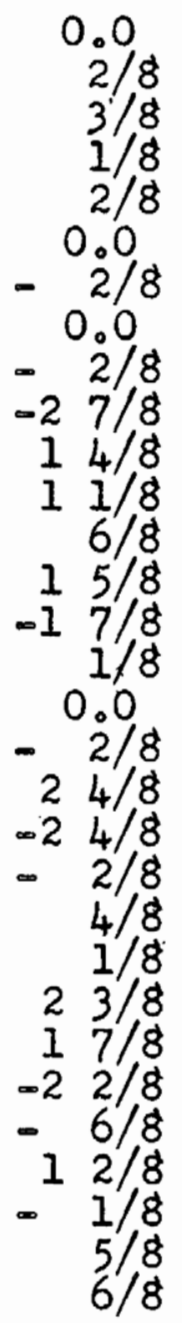 & $\begin{array}{ll}55 & 1 / 8 \\
55 & 3 / 8 \\
55 & 2 / 8 \\
54 & 7 / 8 \\
54 & 5 / 8 \\
54 & 2 / 8 \\
53 & 5 / 8 \\
53 & 5 / 8 \\
53 & 6 / 8 \\
56 & \end{array}$ & $\begin{array}{r}2 / 8 \\
1 / 8 \\
3 / 8 \\
2 / 8 \\
3 / 8 \\
5 / 8 \\
0.0 \\
-21 / 8 \\
-22 / 8\end{array}$ \\
\hline
\end{tabular}


BIBLIOGRAPHY

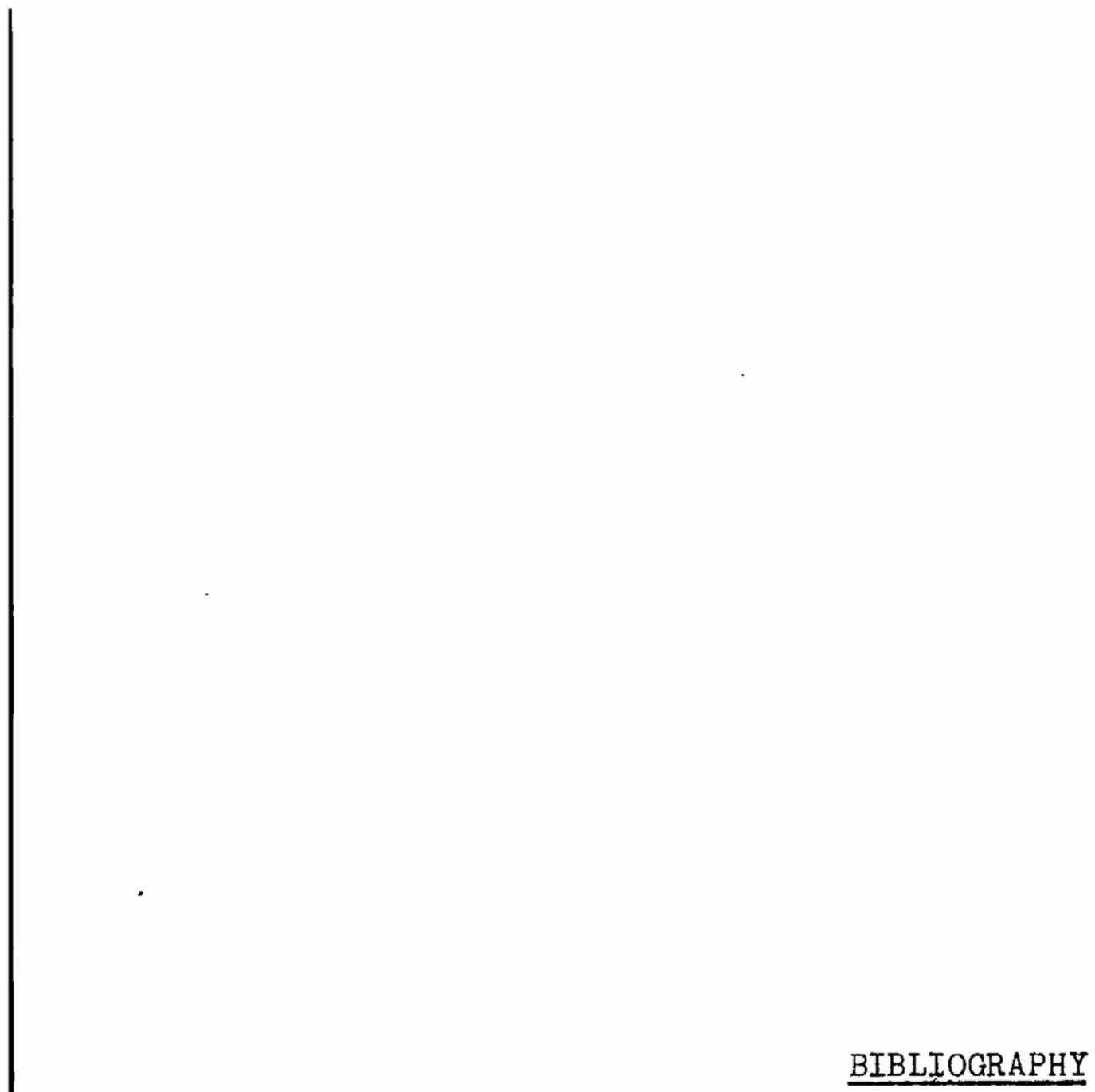


Abels, H., "Beobachtungen der täglichen Periode der Temperatur im Schnee und Bestimmung des Wärmeleitvermögens des Schnees als Funktion der Dichte," Rep. Meteor. Petersburg, Bd. 16, No. 1,1892 .

Ahlmann, H. W: son and A. Tveten, "The Recrystallization of Snow into Firn and the Glaciation of the latter," Geografiska. Annaler, Vol. 5, Ht. 1, 1923. Pp. 52-58.

Ahlmann, H. W:son, H. U. Sverdrup and H. Olsson, "Scientific Results of the Norwegian-Swedish Spitsbergen Expedition in 1934, Parts I-VIII," Geografiska Annaler, Vol. 17, Ht. 1-2 \& 3-4, 1935. Pp. 29-88 and 145-217, and Vol. 18, Ht. 1 \& 3-4, 1936. Pp. 34-73 and 225-43.

Ahlmann, H.W:son and S. Thorarinsson, "Scientific Results of the Swedish-Icelandic Investigations 1936-37-38, Part V: Ablation," Geografiska Annaler, Vol. 20, Ht. 3-4, 1938. Pp. 171-233。

"The Vatnajökull Glacier. Preliminary Report on the Work of the Swedish-Icelandic Investigations, 1936-1937," The Geographical Review, Vol. 28, No. 3, 1938. Pp. 412-38.

Ahlmann, $H_{0} \mathrm{~W}$ :son and $\mathrm{B}_{0}$ E. Eriksson, "Revet Station and the Froya Glacier - North East Greenland- in 1939-40," Geografiska Annaler, Vol. 28, Ht. 3-4, 1946. Pp. 227-57.

Ahlmann, H. W:son, H. F. Johansson and E. Woxnerud, "Scientific Investigations in the Kebnekajse Massif, Swedish Lappland, Parts I-IV," Geografiska Annaler, Vol. 33, Ht. 1-2 \& 3-4, 1951. Pp. 90-143.

Ahlmann, H. W:son, "Glaciers in Jotunheim and their Physiography" Geografiska Annaler, Vol. 4, Ht. 1, 1922. Pp. 1-57.

"Scientific Results of the Swedish-Norwegian Arctic Expedition in the Summer of 1931: Part 8: Glaciology," Geografiska Annaler, Vol. 15, Ht. 2-3, 1933. Pp. 16i-216.

"Melting Process during the Ablation Period," Geografiska Annaler, Vol. 15, Ht. 2-3, 1933. Pp. 201-06.

"Present Glaciation round the Norwegian Sea," Geografiska Annaler, Vol. 15, Ht. 4, 1933. Pp. 312-48.

"Contribution to the Physics of Glaciers," The Geographical Journal, Vol. 86, No. 2, 1935. Pp. 97-113.

"The Stratification of the Snow and Firn on Isachsen's Plateau," Geografiska Annaler, Vol. 17, Ht. 1-2, 1935. Pp. 29-42. 
Ahlmann, $H$ 。W:son, "Ablation Measurements at the Headquarters on Isachsen's Plateau," Geografiska Annaler, Vol。 17, Ht. 1-2, 1935. Pp. 43-52.

"The Fourteenth of July Glacier," Geografiska Annaler, VoI: 17, Ht. 3-4, 1935. Pp. 167-218.

"The Relative Influence of Precipitation and Temperature on Glacier Regime," Geografiska Annaler, Vol. 22, Ht. 3-4, 1940. Pp. 188-205.

, "Accumulation and Ablation on the Fröya Glacier, its Regime in 1938-39 and 1939-40," Geografiska Annaler, Vol. 24, Ht. 1-2, 1942. Pp. 1-22.

"Glaciological Methods," The Polar Record, Vol. 4, No. 31, 1946. Pp. 315-19.

"Researches on Snow and Ice, 1918-40," The Geographical Journal, Vol. 107, 1946. Pp. 11-28.

"The Froya Glacier in 1939-40," Geografiska Annaler,

Vol? 28, Ht. 3-4, 1946. Pp. 239-57.

, "Den nutidiga klimatfluktuationen och dess utforskande," Norsk Geografisk Tidsskrift, Bd. 11, Nos。3-4, 1947. Pp. $290-326$.

, "Glaciological Research on the North Atlantic Coasts," R. G. S. Research Series, No. 1, 1948. 83 pp.

"The Contribution of Polar Expeditions to the Science of Glaciology," The Polar Record, Vol. 5, Nos. 37-38, 1949. Pp. 324-31。

"Glacier Variations and Climatic Fluctuations," Bowman Memorial Lectures, Series 3, A. G. Soc., New York, $19 \overline{53 .}$ $51 \mathrm{pp}$.

Angström, A., "A study of the radiation of the atmosphere," Smithsonian Misc. Coll., Vol. 65, No. 1, Washington, 1915.

, uber die Gegenstrahlung der Atmosphäre, "Met. Zeitschrift, Bd. 33, No. 12, Braunschweig, 1916.

"On the radiation and temperature of snow and the convection of the air at its surface," Ark. f. mat., astr. och fys., Vol. 13, No. 21, Stockholm, 1918.

"The Radiation Problems and their Geophysical Consequences," Geografiska Annaler, Vol. 2, Ht. 2, 1920. Pp. 169-70. 
Angström, A., "On Radiation and Climate," Geografiska Annaler, Vol. 7, Ht. 1-2, 1925. Pp. 122-42.

"The Albedo of various Surfaces of Ground," Geografiska Annaler, Vol. 7, Ht. 4, 1925. Pp. 323-42.

"On the total Radiation from Sun and Sky at Sveanor," Geografiska Annaler, Voi. 15, Ht. 2-3, 1933. Pp. 151-60.

"On the Dependerce of Ablation on Air Temperature, Radiation and Wind," Geografiska Annaler, Vol. 15, Ht. 4, 1933. Pp. 264-71。

, "Actinometric Measurements," Compendium of Meteorology, American Met. Soc., Boston, 1951. Pp. 50-57.

Baird, P. D. and others, "Preliminary Report, Baffin Island Expedition, 1950," Arctic, Vol. 3, No. 3, 1950. Pp. 131-49.

Baird, P. D., "Method of Nourishment of the Barnes Ice Cap," The Journal of Glaciology, Vol. 2, No. 1l, 1952. Pp.2-9.

Baird, P. D., W. H. Ward and S. Orvig, "The Glaciological Studies of the Baffin Island Expedition, 1950, Parts 1 \& 2," The Journal of Glaciology, Vol. 2, No. 11, 1952. Pp. 2-2

Baird, P. B. and others, "Baffin Island Expedition, 1953: A Preliminary Field Report," Arctic, Vol. 6, No. 4, 1953. Pp. 227-51.

Baird, P. D., "Cumberland Peninsula of Baffin Island," Canadian Geographical Journal, Vol. 48, No. 3, March, 1954. Pp. 88-97.

Baur, F., "Das Klima der bisher erforschten Teile der Arktis," Arktis, Bd. 2, Ht. 3-4, 1929. Pp. 77-89, 110-20.

Belknap, R. L., "The Michigan-Pan American Airways Greenland Expedition: Preliminary Results," Geographical Review, Vol. 24, No. 2, 1934. Pp. 205-18.

"Meteorological Report of the University of MichiganPan American Airways Greenland Expedition," University of Michigan Studies, Scientific Series, Vol. 6, Part 2, 1941. Pp. 191-95.

Blake, W., "Studies of the Grinnell Glacier, Baffin Island," Arctic, Vol. 6, No. 2, 1953. P. 167.

"British Expedition to North Baffin Island, 1938-39," The Polar Record, Vol. 3, No. 19, 1940. P.,226:

Carles, L.-M., "Climatologie de l'inlandsis Groenlandais," La Presse Thermale et Climatique, No. 3-4, 1953. $14 \mathrm{pp}$. 
Church, J. E., "Evaporation at high altitudes and latitudes," Trans. Am. Geophys. Union, 15th Annual Meeting, Washington, 1934.

Meteorological Studies: Climate and Evaporation in Alpine and Arctic Zones," Reports of the Greenland Expedition of the University of Michigan. Part II, 1941. Pp. $7-45$.

Conrad, Vo, "Radiation anù Cloudiness," Trans. Am, Geoph. Union, 25th Annual Meeting. Reports and Papers, Part 3, 1944.

Contributions to our Knowledge of the Meteorology of the Arctic Regions. Published by the Authority of the Meteorological Council. Parts I to IV. London, 1879-85.

Demorest, M., "Greenland's Glacial Anticyclone: A Review," Am. Journal of Science, No. 239, 1941. Pp.771-78.

Devaux, Jo, "L'economie radio-termique des champs de neige et des glaciers," Ann. Physique, Vol. 20, No. 2, 1933.

Devik, $0_{0}$, "Ein Registrierinstrument Zur Messung der Ablation," Det $\mathrm{Kgl}$. Norske Videnskabers Selsk. Forhandlinger, Bd。2, No. 31, 1929.

Die Internationale Polarforschung 1882-1883, Die BeobachtungsErgebnisse der Deutschen Stationen, Bd。1: Kingua Fjord, Berlin, 1886 .

Dorsey, H。Go, "Some Meteorological Aspects of the Greenland Ice Cap," Journal of Meteorology, Vol. 2, No. 3, 1945. Pp. 13542 .

Meteorological Characteristics of Northern Arctic America, thesis submitted for the degree of M.Sc, Massachusetts Institute of Technology, 1949. $71 \mathrm{pp}$.

, "Arctic Meteorology," Compendium of Meteorology. Boston: The Am. Met.Soc., 1951. Pp. 942-5I.

Dorsey, N。E., Properties of Ordinary Water Substance. New York: Reinhold Publishing Corporation, 1940. $673 \mathrm{pp}$.

Drygalski, E。 vo and F。 Machatschek, Gletscherkunde. Wien: Franz Deutiche, 1942. $261 \mathrm{pp}$.

Eriksson, B. E。 "Scientific Results of the Swedish-Norwegian Arctic Expedition in the Summer of 1931, Part VI: Climatology and Meteorology," Geografiska Annaler, Vol. 15, Ht. 2-3, 1933. Pp. 117-50. 


\section{$-232-$}

Eriksson, B. E., "Meteorological Records and the Ablation on the Fröya Glacier in Relation to Radiation and Meteorological Conditions," Geografiska Annaler, Vol. 24, Ht. 1-2, 1942. Pp. 23-50.

, "Till kannedomen om den nutidiga Klimat omraadena kring nordligaste Atlanten," Geografiska Annaler, Vol.25, Ht。 3-4, 1943. Pp. 270-201.

"Meteorological Ojservations at Revet 1939-40," Geografiska Annaler, Vol。28, Ht。3-4, 1946. Pp.229-38.

Etienne, E., "Expeditionsbericht der Grönland-Expedition der Universit Universitlt Leipzig, Bd。13, Leipzig, 1940。

Expeditions Polaires Francaises, Liste Des Publications des Expeditions Arctiques et Antarctiques (Groenland et Terre Adelie). Paris: Missions Paul-Emile Victor, Decembre, 1952. $35 \mathrm{pp}$ 。

, "Expedition en Terre Adelie, 1950-52," Rapports Preliminaires, 20, Serie Scientifique, Missions Paul-Emile Victor, Paris, 1953.

Field, W。 O. and M。M。Miller, "The Juneau Ice Field Research Project," The Geographical Review, Vol. 40, No。2, 1950. Pp. 179-90。

Flint, R. Fo, Glacial Geology and the Pleistocene Epoch. New York: John Wiley \& Sons, Inc., 1947. 589 pp.

Franssila, M。, "A Net Radiation Instrument with Constant Ventilation," Geophysica, Vol。 4, No. 3, Helsinki, 1953. Pp. 131-34。

Freuchen, $P_{0}$, "Report of the first Thule Expedition 1912. Meteorological Observations," Medd。om Gronland, Vol.51, No. 13, Copenhagen, 1915.

Fristrup, B。, Meteorology and Glaciology. A Preliminary Account of the Danish Pearyland Expedition, 1948-49, Arctic, Vol. 3, No. 1, 1950. Pp。9-12.

\section{Pp.'19-33.}

"Peary Land," Naturens. Verden, Vol。35, Nos。1-2, 1951.

"Climate and Glaciology of Peary Land, North Greenland," Assemblee Generale de Bruxelles, U.G.G.I.2 1951, Tome I, Louvain, 1952. Pp. 185-93. 
Fristrup, B., "Danish Expedition to Peary Land, 1947-1950," The Geographical Review, Vol。 42, No. 1, 1952. Pp. 87-97.

Geiger, R., The Climate Near the Ground. Cambridge: Harvard University Press, 1950。 $482 \mathrm{pp}$.

Georgi, J., "Deutsche Inlandeisexpedition nach Grönland unter Leitung von A. Wegener Sommer 1929. Vorläufige Berichte, Meteorologische Ergebni s.je," Zeitschrift d.Ges.f.Erdkunde z. Berlin, 1930。

, "Deutsche Grönlandexpedition Alfred Wegener. Die Meteorologischen Arbeiten der Station Eismitte," Zeitschrift d. Ges. f. Erdkunde z. Berlin, 1932。

" "Die Eismittestation," Wiss. Ergebnisse d. Deut. GrönIandexp. Alfred Wegener, Abt. IV, Leipzig, $1935^{\circ}$

Gier, J. T. and $R_{0} V_{0}$ Dunkle, "Total hemispherical radiometers," Transact. Amer. Inst. Electr. Engin., Vol. 70, 1951. 5 pp.

Gilkey, A. Ko and others, Progress Report, Juneau Ice Field Research Project, Alaska, 1952. New York: Am. Geogr. Soc., 1953.

Glen, A. R., "The Oxford University Arctic Expedition to North East Land, 1935-36," The Geographical Journal, Vol. 90, 1937. Pp. 289-314.

"The Glaciology of North East Land," Geografiska Annaler, Vol: 21, Ht。1, 1939. Pp。1-38.

"The West Ice of North East Land," The Geographical Journal, Vol. 98, 1941. Pp. 65-76 and 135-46.

Gold, L. W., "Snow and Ice Research on the North American Continent," The Journal of Glaciology, Vol。2, No. 14, 1953. Pp. 292-94.

Goldthwait, R. P., "Development of End Moraines in East-Central Baffin Island," The Journal of Geology, Vol. 59, No. 6, 1951. Pp. 567-77.

Greenaway, K. R., "My Experiences with Arctic Flying Weather," Royal Met. Soc, Canadian Branch, Publications, Vol. 1, No. 9, Toronto, 1950。12 $\mathrm{pp}$.

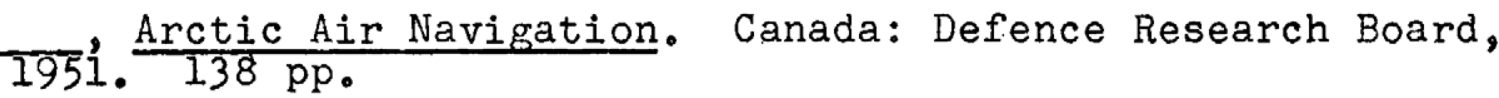

Hamberg, A., "Zur Technik der Gletscheruntersuchungen," Comptes Rendus IX Congres geol. internat. de Vienne 1903. Wien, 1904. 
Hamberg, A., "Anleitung zur Messung der periodischen Grössenveranderungen der Gletscher," Geografiska Annaler, Vol. 12, Ht. 2-3, 1930. Pp. 125-29.

Hann, J。, Handbuch der Klimatologie, Vol. 3, Stuttgart, 1911.

Hare, F. K., The Climate of the Eastern Canadian Arctic and SubArctic and its Influence on Accessibility, thesis presented for the degree of Ph.D., ituniversite de Montreal, 1950. 2 vols. $440 \mathrm{pp}$.

"Recent Investigations into the Distribution of Snow and Ice in Eastern Canada," Assemblee Generale de Bruxelles, U.G.G.I.2 1951, Tome I, Louvain, 1952. Pp. 167-71.

Haurwitz, B., "Insolation in Relation to Cloudiness and Cloud Density," Journal of Meteorology, Vol. 2, No. 3, 1945. Pp. 154-66.

Henry, To J。 Go and G. R。 Armstrong, Aerological Data for Northern Canada. Toronto: Department of Transport, 1949. 271 pp.

Heusser, C.J., "Radiocarbon Dating of the Thermal Maximum in Southeastern Alaska," Ecology, Vol. 34, No. 3, 1953. Pp. $637-40$.

Hobbs, W. H., "Characteristics of the Inland-Ice of the Arctic Regions," Proc.Amer.phil.Soc., Vol. 49, 1910. Pp. 57-129.

, "The Glacial Anticyclones, The Poles of the Atmospheric Circulation," University of Michigan Studies, Scientific Series, Vol. 4. New York: The MacMillan Co., 1926. $198 \mathrm{pp}$.

"Reports of the Greenland Expeditions of the University of Hichigan, 1926-33," University of Michigan Studies, Scientific Series; Vol. 5 , Parts $1 \& 2$.

"Nourishment of the Greenland Continental Glacier," Journal of Geology, Vol. 52, No. 2, 1944. Pp. 73-96.

"The Greenland Glacial Anticyclone," Journal of Meteorology, Vol. 2, No. 3, 1945. Pp. 143-53.

"The Climate of the Arctic as Viewed by the Explorer and the Meteorologist," Science, Vol. 108, 1948. Pp.193-201.

Hoeck, E., "Der Einfluss der Strahlung und „der Temperatur auf den Schmelzprozess der Schneedecke," Beitrage zur Geologie der Schweiz, Hydrologie, Lieferung 8, Bern, 1952. 36 pp.

Hoinkes, $H_{0}$ and $\mathrm{N}$. Untersteiner, "WHrmeumsatz und Ablation auf Alpengletschern," Geografiska Annaler, Vol. 34, Ht. 1-2, 1952. Pp. 99-158. 
Hoinkes, H., "Wärmeumsatz und Ablation auf Alpengletschern, II," Geografiska Annaler, Vol。35, Ht。2, 1953. Pp. 116-140。

Holzappel $R_{0}$, and G. Kirsch, "Uber die Oberflächenwellen der gronlandischen Inlandeises," Met. Zeitschrift, Bd. 51, 1934.

Holzappel, R。, "Die Weststątion und die Station Umanak," Wiss. Ergebnisse d. Deut. Gronlandexp. Alfred Wegener, Abt。 IV, Leipzig, 1935.

Hubley, R。C., "Preliminary Report on Meteorological and Glacio. logical Studies on Lemon Creek Glacier," Progress Report, Juneau Ice Field Research Project, Alaska, 1953. American Geographical Society, 1953. Pp. 16-21。

Hughes, T. Po and $G_{0}$ Seligman, "The Temperature, Meltwater Movement and Density Increase in the Neve of an Alpine Glacier," Monthly Notices, Royal Astronomical Society, Geophysical Suppl., Vol. 4, No. 8, 1939. Pp.616-47.

Instructions for the Operation of the M.S.C. Type G Bimetal Actinograph. Toronto: Department of Transport, Manual 80, 1952. $10 \mathrm{pp}$.

Johnsson, O.H., "Termisk-hydrologiska studier i sjon Klämmingen," Geografiska Annaler, Vol。28, Ht.1-2, 1946. Pp.1154 .

Kalitin, N。 N., "Die Radiationseigenschaften des Schnees und des Eises," IV Conf. Hydro. des Etats Baltiques, Leningrad, 1933.

Kimball, H. H., "Solar Radiation and Its Role," Physics of the Earth--III: Meteorology, Chapter 3. Washington: The National Research Council, 1931. Pp. 35-66.

Klebelsberg, $R$ 。 v., Handbuch der Gletscherkunde und Glazialgeologie. Wien: Springer Verlag, 1948. 2 vols. $1028 \mathrm{pp}$.

Koch, J。 P。 and A. Wegener, "Wissenschaftliche Ergebnisse der Dänischen Expedition nach Dronning Louises-Land und quer uber das Inlandeis von Nordgron].and 1912-13 unter Leitung von Hauptmann J.P. Koch," Medd. om Grönland, Vol. 75, Parts 1 and 2, Copenhagen, 1930。404 and $272 \mathrm{pp}$.

Kopp, W., "Die Oststation," Wiss. Ergebnisse d. Deut. Grönlandexp. Alfred Wegener, Abt. IV, Leipzig, 1935.

Lauscher, F., "Dampfdruck und Ausstrahlung in einem Gebirgsland," Gerl. Beitr. 2. Geoph., Bd. 51, Leipzig, 1937.

Lawrence, D. B., "Glacier Fluctuations for Six Centuries in Southeastern Alaska and Its Relation to Solar Activity," The Geographical Review, Vol. 40, No.2, 1950. Pp. 19l-223. 
Lawrence, D. B., "Glacier Fluctuations in northwestern North America within the past six Centuries," Assemblee Generale de Bruxelles, U。G.G.I., 1951, Tome I, Louvain, 1952. Pp. 161-66.

Lawrence, D。B。 and J. A. Elson, "Periodicity of Deglaciation in North America since the late Wisconsin Maximum," Geografiska Annaler, Vol. 35, Ht. 2, 1953. Pp. 83-104.

Lindsay, M., "The British I'rans-Greenland Expedition, 1934, The Geographical Journal, Vol. 85, No. 5, 1935. Pp. 393-411, and Vol. 86, No. 3, 1935. Pp. 235-51.

Linke, F. Meteorologisches Taschenbuch II. Leipzig: Ak. Verlagsgeselischaft, 1939.

Loewe, F., "Deutsche Grönlandexpedition Alfred Wegener. Abschmelz- und Zuwachsmessungen," Zeitschrift d. Ges. f. Erdkunde z. Berlin, 1932。

"Die Bedeutung des Schneefegens für den Massenhaushalt von 'Inlandeisen," Met. Zeitschrift, 1933.

"Das Klima des Grönländischen Inlandeises," Part 3 of Klima des Kanadischen Archipels und Gronlands, Bd. 2, Teil K of Handbuch der Klimatologie, Berlin: Verlag von Gebrlder Borntraeger, 1935. Pp.67-101.

"Glaciological Work in Terre Adelie in 1951: Preliminary Report," The Journal of Glaciology, Vol. 2, No. 14, 1953. Pp. $248-49$.

Lysgaard, L., "Recent Climatic Fluctuations," Folia Geographica Danica, Tome 5, Copenhagen, 1949.

"On the Present Climatic Variation," Centenary Proceedings of the Royal Met. Soc., London, 1950. Pp. 206-11.

Malmgren, F., "Studies of Humidity and Hoar-Frost over the Arctic Ocean," Geofysiske Publikasjoner, Vol. 4, No. 6, Oslo, 1926. $20 \mathrm{pp}$.

Matthes, F. E., "Ablation of snow fields at high altitude by radiant solar heat," Trans. Am. Geophys. Union, 15th Annual Meeting, Washington, 1934.

"The Glacial Anticyclone Theory Examined in the Light of Recent Meteorological Data from Greenland," Transactions American Geophysical Union, Vol. 27, 1946. Pp. 324-41.

"Glaciological Studies," The Geographical Review, Vol. 37, 1947. Pp. 154-56. 
Matthes, F。E。 and A。 D。 Belmont, "The Glacial Anticyclone Theory Examined in the Light of Recent Meteorological Data from Greenland - Part 2 " Transactions American Geophysical Union, Vol. 31, April, 1950. Pp。174-82。

Maurstad, A., "Die Meteorologischen Beobachtungen whhrend Arne H8ygaard und Martin Mehren"s Durchquerung von Gronland 1931," Geofysiske Publikasjcier, Vol。9, No. 10, Oslo, 1932. 11 pp.

Mercer, JoHo, The Physiography and Glaciology of Southernmost Baffin Island thesis presented for the degree of Ph.D. 8 McGill University, 1954。150 pp.

Meteorology of the Canadian Arctic. Toronto: Meteorological Division, Department of Transport, 1944. $85 \mathrm{pp}$.

Middleton, W。E。Ko and A。F。 Spilhaus, Meteorological Instruments. Toronto: University Press, 1953. $286 \mathrm{pp}$

Miller, M。 Mo, "1951 Winter Season," Juneau Ice Field Research Project, Report No。 8, December, 1953. 65 pp。

Mirrlees, S. To A。 "Meteorological results of the British Arctic Air $\sim$ Route Expedition 1930-31," Met. Office Geophysical Mem., Vol. 7, No.61, London, 1934。

Mohn, H. and F。 Nansen, "Wissenschaftliche Ergebnisse von Dr. F: Nansen ${ }^{\circ}$ Durchquerung von Gronland 1888," Peterm. Mitt.: Erg。-Heft 105, Gotha, 1892。

Mosby, H., "Sunshine and Radiation," The Norwegian North Polar Expedition with the "Maud" 1918-25. Scientific Results, Vol. Ia, No. 7, Bergen, 1932。

Moss, $R_{0}$, "The Physics of an Ice-cap," The Geographical Journal, Vol.92, 1938. Pp.211-27.

Mörikofer, $W_{0}$ and $C$. Thams, "Erfahrungen mit dem Bimetallaktinographen Fuess-Robitzsch," Meteorologische Zeitschrift, Bd. 54, 1937. Pp。360-71。

Nielsen, I. E。 and A. S. Post, "The Castner Glacier Region, Alaska," The Journal of Glaciology, Vol。2, No. $14,1953$. Pp. 277-80.

Nyberg, A., "Temperature Measurements in an Air Layer very close to a Snow Surface," Geografiska Annaler, Vol. 20, Ht. 3-4. 1938. Pp. 234-75.

Odell, N. E. "The Glaciers and Morphology of the Frans Josef Fjord Region of North-east Greenland," The Geographical Journal, Vol. 90, 1937. Pp. 111-25 and 233-58. 
Olsson, H., "Sunshine and Radiation, Mount Nordenskiolld, Spitsbergen," Geografiska Annaler, Vol. 18, Ht. 1, 1936. Pp. 94118 .

"Radiation Measurements on Isachsen's Plateau," Geografiska Annaler, Vol. 18, Ht. 3-4, 1936. Pp. 225-43.

Orvig, S., The Climate of the Ablation Period on the Barnes IceCap in 1950, thesis presonted for the degree of M.Sc., McGill University, 1951. 170 op.

"The Climate of the Ablation Period on the Barnes IceCap' in 1950," Geografiska Annaler, Vol. 33, Ht. 3-4, 1951. Pp. 166-209. 1953. "Meteorology - Ice cap station," Arctic, Vol. 6, No. 4,
Pp. 237-38.

Pearce, D. C., "A Bibliography on Snow and Ice," National Research Council, Division of Building Research, Bibliography, No. I, 1951. $69 \mathrm{pp}$.

Petterssen, S., "Changes in the General Circulation Associated with the Recent Climatic Variation," Geografiska Annaler, Vol. 31, Ht. 1-4, 1949. Pp. 212-21.

, "Some Aspects of the general circulation of the atmosphere," Centenary Proceedings of the Royal Met. Soc., London, 1950. Pp. 120-55.

Pewe, T. L. and others, "Multiple Glaciation in Alaska, A Progress Report," Geological Survey Circular, No: 289, Washington, 1953. $13 \mathrm{pp}$.

Phillips, H., "Zur Theorie der Wärmestrahlung in Bodennähe, "Gerl. Beitr.z. Geoph., Bd. 56, Leipzig, 1940。

Pooler, F., "Brief Discussion of some theoretical Aspects and Recommendations for future Meteorological Studies," Juneau Ice Field Research Project, Report No. 6, 1952. Pp. 95-99.

Proceedings of the Second Glaciological Conference, under the Auspices of The Arctic Institute of North America, The American Geographical Society, and The Research Committee on Glaciers. New York: 1951. $46 \mathrm{pp}$.

Prohaska, F. and C. Thams, "Neue Untersuchungen über die Strahlungseigenschaften der Schneedecke," Helv. Phys. Acta., Bd. 13, Basel, 1940.

Quervain, A, de. and P. Mercanton, "Ergebnisse der Schweizerischen Grônlandexpedition 1912-13," Medd. om Gronland, Vol. 59, No. 5, Copenhagen, 1925. 
Quervain, M. R. de, "Snow and Ice Problems in Canada and the U.S.A.," Nat. Res. Council of Canada, Technical Report, No. 5, Ottawa, 1950. $70 \mathrm{pp}$.

"Zur Verdunstung der Schneedecke," Archiv für Meteorologie, Geophysik und Bioklimatologie, serie B, Bd. 3, 1951. Pp. 47-64.

Rae, R. W., Climate of the Canadian Arctic Archipelago. Toronto: Department of Transport, I951. $90 \mathrm{pp}$.

Reuter, H., "Uber die Theorie des Wärmehaushaltes einer Schneedecke," Archiv fur Meteorologie, Geophysik und Bioklimatologie, Serie A, Bd. 1, Ht. 1, Wien, 1948. Pp. 62-92.

"Zur Theorie des Wärmehaushaltes strahlungsdurchlässiger Medien," Tellus, Vol. 1, No. 6, 1949. Pp. 6-14.

Review of the Properties of Snow and Ice. SIPRE Report, No. 4, University of Minnesota, July, 1951. $156 \mathrm{pp}$.

Richter, G. D., "Snow Cover, Its Formation and Properties," Academy of Science, U.S.S.R., Popular Science Series, Publishing House of the Academy of Science, U.S.S.R., Moscow, 1945. 112 pp. (Translation)

Robin, G., "Queen Maud Land: The Scientific Results of the International Expedition," The Geographical Magazine, Vol. 25, No. 6, 1952. Pp. 283-93.

Rogstad, 0., "Avsmeltningen paa Jostedalsbreen i forhold til lufttemperaturen," Norsk Geografisk Tidsskrift, Bd. 13, Nos. $1-2,1951$. Pp. 10-16.

Roy, S. K., "The Grinnell Ice-Cap," Geol. Ser. Field Museum of Natural History, Vol. 7, No. I, 1937. Pp. 1-19.

"Additional Notes on the Grinnell Ice-Cap," Geol. Ser. Field Museum of Natural History, Vol. 7, No. 4, 1938. Pp. 59-69.

Röthlisberger, H., "Seismic Sounding," Arctic, Vol. 6, No. 4, 1953. Pp. 234-37.

Sandford, K. S., "The Glacial Conditions and Quaternary History of North East Land," The Geographical Journal, Vol. 74, 1929. Pp. 451-70 and 543-52.

Sauberer, F. and I. Dirmhirn, "Untersuchungen uber die Strahlungsverh Geophysik und Bioklimatologie, Serie B, Bd. 3, 1951. Pp. 25669. 
Sauberer, F. and I. Dirmhirn, "Der Strahlungshaushalt horizontaler Gletscherflachen auf dem hohen Sonnblick," Geografiska Annaler, Vol. 34, Ht. 3-4, 1952. Pp. 261-90.

Scherhag, R., "Die Erwarmung der Arktis," Journal Conseil Permanent International pour l'Exploration de la Mer, Vo1. 12, 1937. Pp. 263-76.

Schumacher, No J., "The Mavilieim expedition, 1949-52. Parts I and II," Weather, Vol. 7, No. 10, 1952. Pp. 314-19. Vol. 7, No. $11,1952 . \mathrm{Pp} .327-34$.

Schytt, V., "Glaciologiska arbeten i Kebnekajse," Ymer, Vol. 67, Ht. 1, 1947. Pp. 18-42.

, "Refreezing of the Melt-water on the Surface of Glacier Ice," Geografiska Annaler, Vol. 31, Ht. 1-4, 1949. Pp. 22228 .

"Die norwegisch-britisch-schwedische Antarktisexpedition 1949 bis 1952," Die Erde, Ht. 3-4, 1953. Pp. 179-94.

"Glaciology in Queen Maud Land: Work of the NorwegianBritish-Swedish Antarctic Expedition, The Geographical Review, Vol. 44, No. 1, 1954. Pp. 70-87.

Sharp.R. P., "Glacial-Meteorological Investigations in Swedish Lappland: Review Article," Arctic, Vol. 3, No. 2, 1950. Pp. $113-16$.

, "Accumulation and Ablation on the Seward-Malaspina GIacier System, Canada-Alaska," Bull. Geol. Soc. Am.., Vol. 62, 1951. Pp. 725-43.

"Glaciological Studies on Malaspina Glacier, Alaska, and Saskatchewan Glacier, Canada, in 1953," Status Report, Nov., 1953. $6 \mathrm{pp}$.

"Glacier Variations and Climatic Fluctuations: Review Article," Arctic, Vol. 6, No. 4, 1953. Pp. 272-73.

Slater, G., "Studies on the Rhone Glacier, 1927. The Relationship between the average air temperature and the rate of melting of the surface of the glacier," Quart. Journal Royal Met. Soc., Vol. 55, 1929. P. 385.

Sorge, E., "Deutsche Grönlandexpedition Alfred Wegener. Glaziologische Untersuchungen in Station Eismitte," Zeitschrift d. Ges. f. Erdkunde z. Berlin, 1932. 
Sverdrup, H. U., The Norwegian North Polar Expedition with the "Maud" 1918-25. Scientific Results, Vol. 2: Meteorology, Part 1: Discussion. Bergen, 1935.

"Varmeutvekslingen mellem en sneflate og luften," $\mathrm{Chr}$. Michelsens Institutt, Beretninger, Vol. 5, No. 3, 1935. $33 \mathrm{pp}$.

, "The Temperature of the Firn on Isachsen's Plateau, and General Conclusions regarding the Temperature of the Glaciers on West-Spitsbergen," Geografiska Annaler, Vol. 17, Ht. 1-2, 1935. Pp. 53-88.

, "Ubersicht über das Klima des Polarmeeres und des Kanaw dischen Archipels," Handbuch der Klimatologie, Bd. 2, Teil K. Berlin: Verlag von Gebrlider Borntraeger, 1935. Pp. 3-29.

of July Glacier in Relation to Radiation and Meteorological Conditions," Geografiska Annaler, Vol. 17, Ht. 3-4, 1935. Pp. 145-66.

Field," Geofysiske Publikasjoner, Vol. Il, No. 7, 1936. pp.

"Results of the Mieteorological Observations on Isachsen's Plateau," Geografiska Annaler, Vol. 18, Ht. 1, 1936. Pp. 3447.

Thams, C., "Uber die Strahlungseigenschaften der Schneedecke," Gerl. Beitr. z. Geoph., Bd. 53, Leipzig, 1938.

The American Ephemeris and Nautical Almanac for the Year 1953. Washington: The Nautical Almanac Office, United States Naval Observatory, 1951. $642 \mathrm{pp}$.

Thompson, H. R., "Geomorphology," Arctic, Vol. 6, No. 4, 1953. Pp. $243-45$.

Thorarinsson, S., "Present Glacier Shrinkage, and Eustatic Changes of Sea Level," Geografiska Annaler, Vol. 22, Ht. 3-4, 1940. Pp. 131-59.

Troll, C., "Fünfundzwanzig Jahre nordisch-arktische Gletscherforschung unter Leitung von H. W:son Ahlmann," Geol. Rundschau, $\mathrm{Bd}$. 34, 1943. Pp. 282-93.

"Schmelzung und Verdunstung von Eis und Schnee in Ihrem Verhältnis zur Geographischen Verbreitung der Ablationsformen," Erdkunde, Bd. 3, Ht. 1, 1949. Pp. 18-29. 
Victor, P. E., "The French Expedition to Greenland, 1948," Arctic, Vol. 2, No. 3, 1949. Pp. 135-48.

, "French Expedition to Greenland, 1949-1950," The Polar Record, Vol. 6, No. 42, 1951. Pp. 258-62.

Wallen, C.C., "Glacial-Meteorological Investigations on the Karsa Glacier in Swedish Lappiand, 1942-1948," Geografiska Annaler, Vol. 30, Ht. 3- is 1948. Pp. 451-672.

" "The Shrinkage of the Karsa Glacier and its Probable Meteorological Causes," Geografiska Annaler, Vol. 31, Ht. 14, 1949. Pp. 275-91.

"Influences Affecting Glacier Extension in Northern Sweden," Assemblee Generale de Bruxelles, U.G.G.I., 1951 , Tome I, Louvain, 1952. Pp。145-53.

Ward, R. DeC., C. F。 Brooks and A. J. Connor, "The Climates of North America," Handbuch der Klimatologie, Bd. 2, Teil J. Berlin: Verlag von Gebrüder Borntraeger, 1938. $92 \mathrm{pp}$.

Ward, W. H., "The Physics of Deglaciation in Central Baffin Island," The Journal of Glaciology, Vol. 2, No. 11, 1952. Pp. $9-22$.

230'-34. "Glacier Physics," Arctic, Vol. 6, No. 4, 1953. Pp.

Ward, W. H., and S. Orvig, "The Heat Exchange at the Surface of the Barnes Ice Cap during the Ablation Period," The Journal of Glaciology, Vol. 2, No. 13, 1953. Pp. 158-68.

Ward, W. H., and P. D. Baird, "Studies in Glacier Physics on the Penny Ice Cap, Baffin Island, 1953. Part I: A Description of the Penny Ice Cap, Its Accumulation and Ablation," The Journal of Glaciology, Vol. 2, No. 15, April, 1954.

Weather Bureau and Corps of Engineers, "Cooperative Snow Investigations, Progress Report 1945-1950," Technical Report No. 6-4, Oakland Army Base, Oakland, California: March, 1950.

Wegener, K. and R. Holzappel, "Das Schneefegen," Wiss. Ergebnisse der Deut. Gronland Expedition Alfred Wegener 1929 und 1930-31, Bd. 1, Leipzig, 1933.

Wegener, K., "Der Schwerewind," Ann. d. Hydrogr., Vol. 62, 1934. - "Zusammenfassung der Wissenschaftlichen Ergebnisse," Wissenschaftliche Ergebnisse der Deutschen Grönland Expedition Alfred Wegener 1929 und 1930-31, Bd. 7, Leipzig, 1940. 
Willett, H. C., "Temperature Trends of the Past Century," Centenary Proceedings of the Royal Met. Soc., London, 1950. Pp. 195-206.

Wonders, W. C., Climate of the Canadian Arctic Archipelago, the sis submitted for the degree of Ph.D., Toronto University, 1951.

Wood, W. A., "Project Snow rurnice," Arctic, Vol. 1, No. 2, 1948. Pp. 107-12.

Wright, C. S. and R.E. Priestley, "Glaciology," British (Terra Nova) Antarctic Expedition, 1910-13. London, 1922. $581 \mathrm{pp}$. 


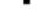

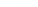

